\title{
Syntheses of fused pyrroloheterocycles, isatins, approach towards the indole fragment of nosiheptide and a base-mediated formation of 3-hydroxycarbazoles
}

Sobha Priyadarshini Gorugantula

West Virginia University

Follow this and additional works at: https://researchrepository.wvu.edu/etd

\section{Recommended Citation}

Gorugantula, Sobha Priyadarshini, "Syntheses of fused pyrroloheterocycles, isatins, approach towards the indole fragment of nosiheptide and a base-mediated formation of 3-hydroxycarbazoles" (2009). Graduate Theses, Dissertations, and Problem Reports. 2851.

https://researchrepository.wvu.edu/etd/2851

This Dissertation is protected by copyright and/or related rights. It has been brought to you by the The Research Repository @ WVU with permission from the rights-holder(s). You are free to use this Dissertation in any way that is permitted by the copyright and related rights legislation that applies to your use. For other uses you must obtain permission from the rights-holder(s) directly, unless additional rights are indicated by a Creative Commons license in the record and/ or on the work itself. This Dissertation has been accepted for inclusion in WVU Graduate Theses, Dissertations, and Problem Reports collection by an authorized administrator of The Research Repository @ WVU.

For more information, please contact researchrepository@mail.wvu.edu. 


\title{
Syntheses of Fused Pyrroloheterocycles, Isatins, Approach Towards the Indole Fragment of Nosiheptide and a Base-Mediated Formation of 3-Hydroxycarbazoles
}

\author{
Sobha Priyadarshini Gorugantula
}

\author{
Dissertation submitted to the \\ Eberly College of Arts and Sciences \\ at West Virginia University \\ in partial fulfillment of the requirements \\ for the degree of
}

Doctor of Philosophy

in

Chemistry
Björn C. G. Söderberg, Ph.D., Chair
Patrick S. Callery, Ph.D.
George A. O'Doherty, Ph.D.
Jeffrey L. Petersen, Ph.D.
John H. Penn, Ph.D.
C. Eugene Bennett Department of Chemistry
Morgantown, West Virginia
2009

Keywords: Pd-Catalyzed N-Heteroannulation, Pyrroloheterocycles, Isatins, Carbazoles, Nosiheptide 


\title{
Abstract \\ Syntheses of Fused Pyrroloheterocycles, Isatins, Approach Towards the Indole Fragment of Nosiheptide and a Base-Mediated Formation of 3-Hydroxycarbazoles
}

\author{
Sobha Priyadarshini Gorugantula
}

The nitro group has been and still is one of the few functional groups widely studied in synthetic organic chemistry. The reactivity of the nitro group has had important applications in the syntheses of many complex organic molecules, either through its assistance in the formation of new carbon-carbon bonds or in the formation of carbonheteroatom bonds. Of late, the nitro group has become an important source of nitrogen in organic molecules, thus spawning the syntheses of a range of nitrogen heterocycles. This dissertation is one such work, wherein the reactivity of the nitro group has been exploited with respect to the syntheses of nitrogen heterocycles. The palladiumcatalyzed reductive $\mathrm{N}$-heteroannulation reaction discovered in our laboratories a decade ago, has been utilized to synthesize a group of fused pyrroloheterocycles from the corresponding nitro-alkenylarenes. Also, these annulation conditions, when applied to 1(2-haloethynyl)-2-nitrobenzenes, led to the formation of isatins. The isolation of a few stable 2-haloisatogens en route to the isatins is an important aspect in this conversion.

In addition, the possibility of executing an intramolecular nucleophillic attack on 3-(2nitrophenyl)-2-cyclohexenone derivatives to afford hydroxy-carbazoles was investigated. A short synthetic approach to a model indole fragment of the natural product nosiheptide was also designed and attempted. 


$$
\begin{aligned}
& \text { \%० } \\
& \text { Mly Sother } \\
& \text { And To } \\
& \text { The Mlemory OP Mly Srather }
\end{aligned}
$$

Great works are perfformed, not by strength, but by persenerance.

Damuel. Yohnson 


\section{Acknowledgements}

As I sit down to pen a few words on this page, I cannot help reflecting upon the story of a little boy who drew an empty hand, when asked to draw a picture of something he was thankful for. The abstract drawing of his teacher's hand speaks more than any word can ever say about being thankful. With great pleasure and profound respect, I take this opportunity today to express my sincere gratitude to my teacher, advisor and mentor, Dr. Björn Söderberg, the hand that accompanied me in my graduate education. I consider myself very fortunate for being a student to such a patient, broad-minded exceptional chemist, an excellent teacher and above all, a wonderful person.

I would also like to thank Dr. George O'Doherty, Dr. Patrick Callery, Dr. Jeffrey Petersen and Dr. John Penn for their consent to be the members of my Doctoral Defense Committee and their time. Their invaluable advice and suggestions in the preparation of this dissertation are appreciated and acknowledged.

I extend my gratitude to Dr. Novruz Akhmedov for his immense help and assistance in structural determinations using advanced NMR techniques. The financial support from the Department of Chemistry at West Virginia University and NSF is also gratefully acknowledged.

Also in my thoughts are my colleagues and fellow group members, past and present. I thank each one of them for their co-operation and help in my academics and research. To all my friends who stood by me through this journey, I say "Thank You!" Most importantly, I am very grateful to my family, especially to Babai, Uma Aunty, Prem Uncle and Marie Aunty for their love, support and guidance throughout my life. Ultimately, to my parents: Had it not been for you, Mommy and Daddy, I would have never been the person I am today. For all that you gave me and for all that you are to me, words are never enough to say how thankful and fortunate I am to have you both as my parents. 


\section{Table of Contents}

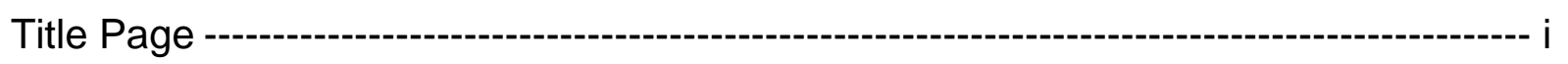

Abstract----

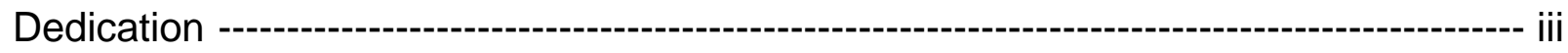

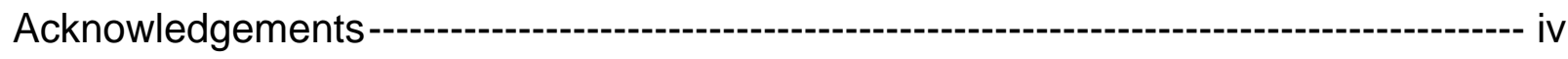

Table of Contents ---

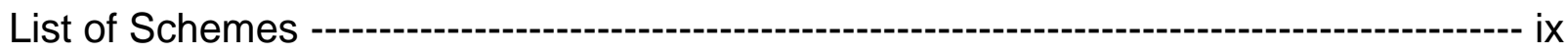

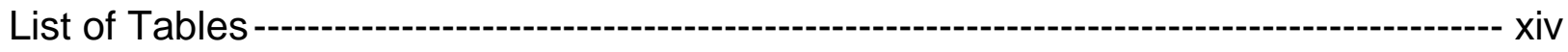

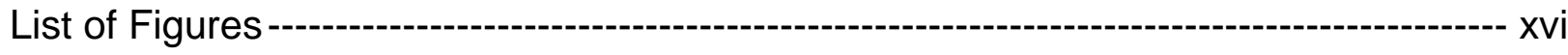

\section{Chapter 1}

\section{Palladium-Catalyzed Syntheses of Fused Pyrroloheterocycles}

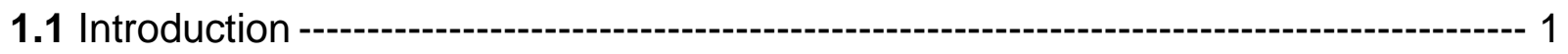

1.2 Notable Synthetic Routes to Fused (5,5) Pyrroloheterocyclic Systems -------------- 6

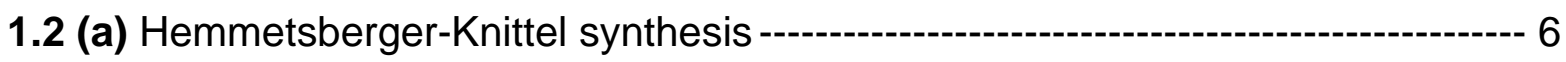

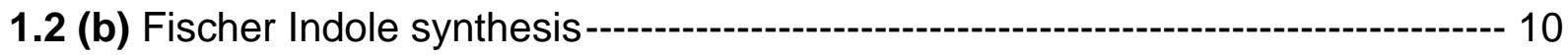

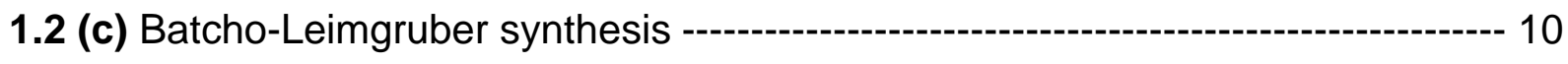

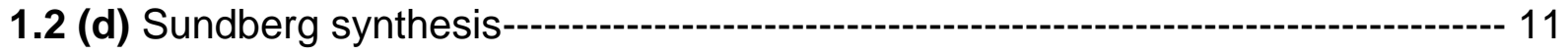

1.2 (e) Cadogan-Sundberg synthesis--------------------------------------------------- 12

1.2 (f) Snyder's synthetic approaches to thienopyrroles ------------------------------ 14

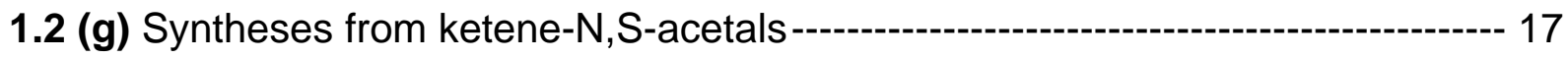


1.2 (h) Synthesis of a pyrrolo[3,2-d]thiazole derivative

1.3 Transition metal mediated syntheses of fused pyrroloheterocycles------------------- 20

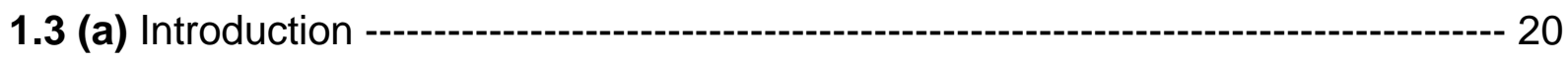

1.3 (b) Palladium-catalyzed reductive N-heteroannulation ---------------------------- 22

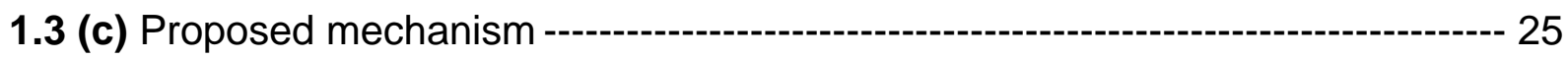

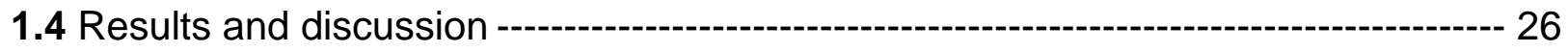

1.4 (a) Syntheses of thieno[3,2-b]pyrrole and thieno[2,3-b]pyrrole derivatives-------- 27

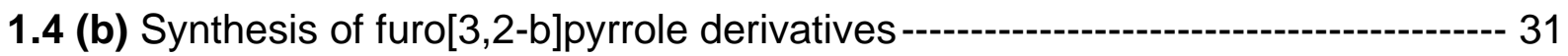

1.4 (c) Synthesis of 2-methyl-5-phenyl-4H-pyrrolo[3,2-d]thiazole ----------------------- 33

1.4 (d) Syntheses of pyrrolo[3,2-d]imidazole and pyrrolo[2,3-d]imidazole derivatives

1.4 (e) Attempted synthesis of pyrrolo[2,3-d]isoxazole------------------------------------ 36

1.4 (f) Attempted syntheses of pyrrolopyrrole derivatives ---------------------------------- 37

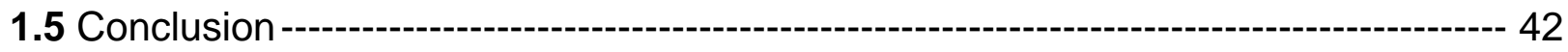

\section{Chapter 2}

\section{Palladium-Catalyzed Synthesis of Isatins}

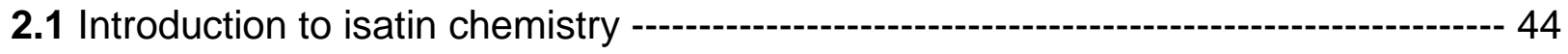

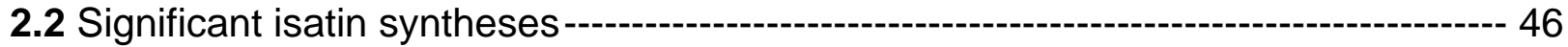

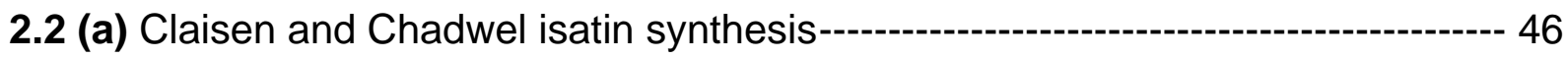

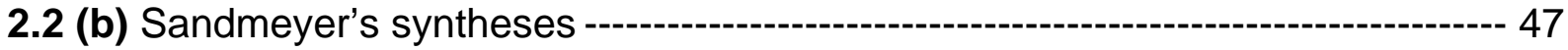

2.2 (c) Stolle's synthesis --- 49

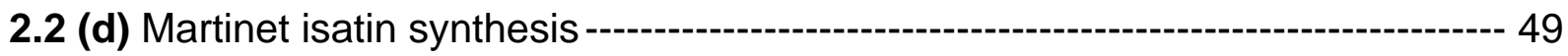




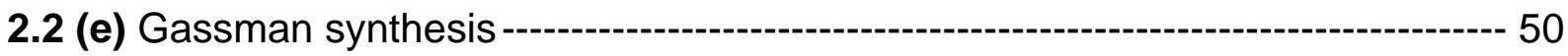

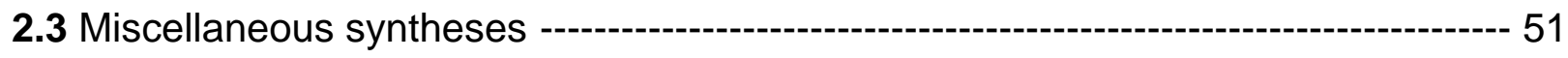

2.4 The significance of isatin --- 54

2.5 Results and discussion -- 60

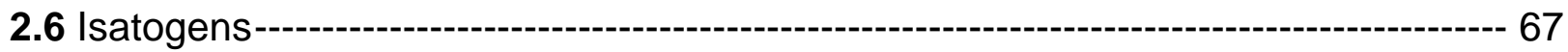

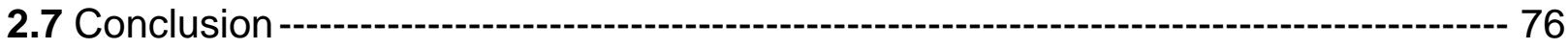

\section{Chapter 3}

\section{Carbazoles and 3-Hydroxycarbazoles}

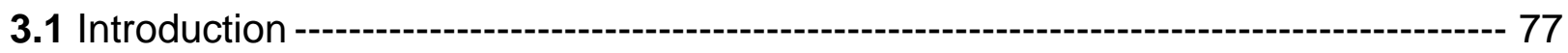

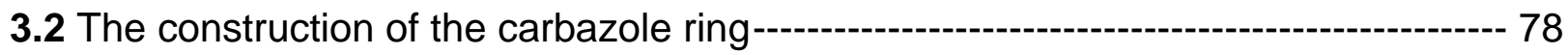

3.2 (a) The Fischer indole synthesis --- 78

3.2 (b) The "heteroannulation" method--.-- 79

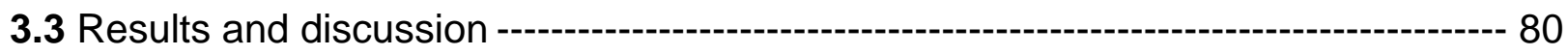

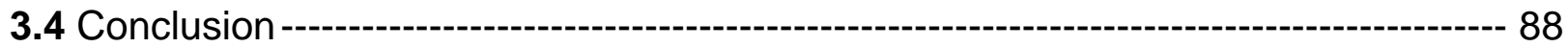

\section{Chapter 4}

\section{Attempted Synthesis of the Model Indole Fragment of Nosiheptide}

4.1 Introduction --- 90

4.2 The "Moody" group's syntheses of the model indole fragment -------------------- 91

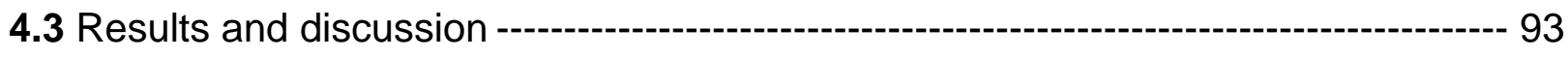

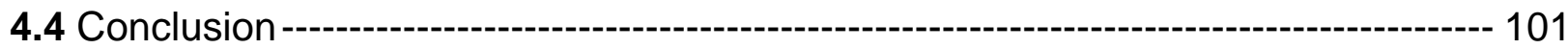




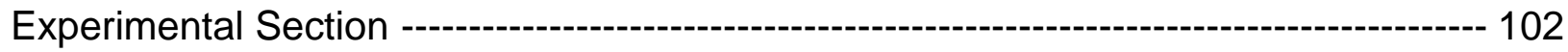

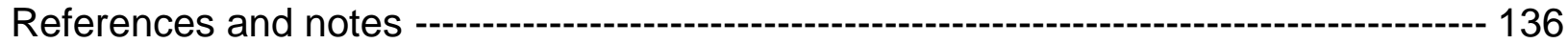

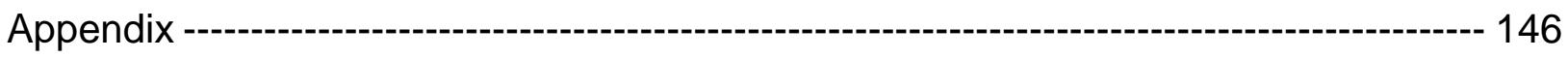




\section{List of Schemes}

Scheme 1: [4+2]cycloaddition to a furo[2,3-b]pyrrole

Scheme 2: Hemmetsberger-Knittel synthesis of the thieno[3,2-b]pyrrole and thieno[3,2-b]pyrrole

Scheme 3: The azirine intermediates isolated by Knittel en route to indole-2-carboxylates 7

Scheme 4: Equilibrium between the nitrene and the azirine----------------------------- 8

Scheme 5: The synthesis of a thieno[2,3-b]pyrrole via Fischer's indole synthesis---- 10

Scheme 6: Batcho-Leimgruber synthesis

Scheme 7: The preparation of furo-, thieno- and seleno[3,2-b]pyrroles by the Sundberg reaction

Scheme 8: Plausible mechanism of the Sundberg reaction ----------------------------- 12

Scheme 9: General reaction for the Cadogan-Sundberg synthesis ------------------- 13

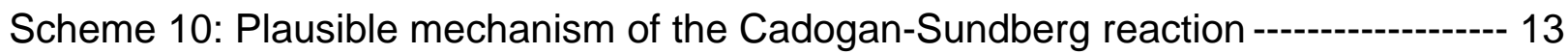

Scheme 11: Modified Reissert indole synthesis: Preparation of thieno[3,2-b]pyrrole-- 15

Scheme 12: 5-Carboethoxy thieno[2,3-b]pyrrole via the Reissert indole synthesis ---- 15

Scheme 13: The alternate syntheses of thieno[3,2-b]pyrroles via the "thiocyanation" route 16

Scheme 14: Synthesis of N-benzylthieno[2,3-b]pyrrole via thiocyanation 17

Scheme 15: Preparation of thieno[2,3-b]pyrroles from ketene-N-S-acetals 19

Scheme 16: Synthesis of the pyrrolo[3,2-d]thiazole derivative via oxidative cyclization 19

Scheme 17: Rhodium (II) catalyzed synthesis of nitrogen heterocycles 20 
Scheme 18: The palladium-catalyzed reductive de-oxygenation reaction by the "Cenini" group ------------------------------------------------------------------- 23

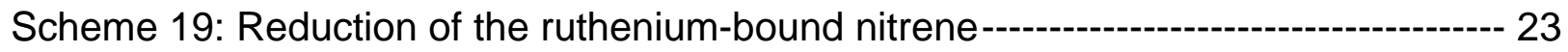

Scheme 20: Watanabe conditions- the palladium- $\mathrm{SnCl}_{2}$ catalyzed formation of

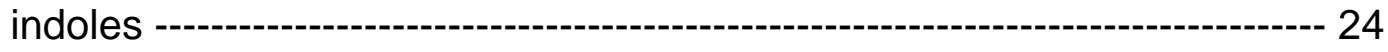

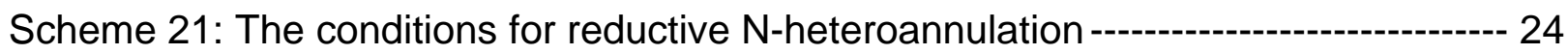

Scheme 22: The reductive N-heteroannulation of the isomeric mixture----------------- 25

Scheme 23: Plausible mechanistic pathways for the N-heteroannulation reaction----- 26

Scheme 24: The general strategy to synthesize the fused pyrroloheterocycles -------- 27

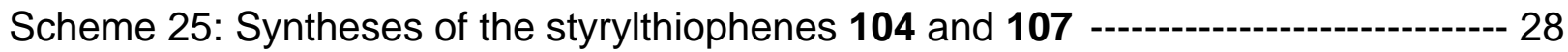

Scheme 26: Synthesis of 3,4-dinitro-2,5-distyrylthiophene (112) ------------------------- 29

Scheme 27: The heteroannulation of 3,4-dinitro,2-5-distyrylthiophene (112) ------------ 30

Scheme 28: Preparation of 4-nitro-5-styryl-2-furanaldoxime (118) ----------------------- 32

Scheme 29: The test reaction on 5-methyl-2-furanaldoxime (116) ------------------------- 32

Scheme 30: Preparation of 2-methyl-4-nitro-5-styrylthiazole (126)------------------------ 33

Scheme 31: Preparation of the two isomeric styrylimidazoles 131 and 132 ------------ 35

Scheme 32: Synthesis of 3-methyl-4-nitro-5-styrylisoxazole (137) ------------------------- 36

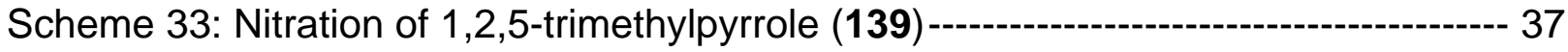

Scheme 34: Synthesis of 1-(4-chlorophenyl)-2-methyl-3-nitropyrrole (149)------------- 39

Scheme 35: Synthesis of 3-nitro-4-(2-phenylethynyl)pyrrole (155)----------------------- 41

Scheme 36: Preparation of N-methyl and N-tosyl derivatives of 3-nitro-4-(2-phenylethynyl)pyrrole---------------------------------------- 41

Scheme 37: The stepwise reduction of isatin to indole as recorded by Baeyer--------45

Scheme 38: The reaction behind Kekule's proposition ---------------------------------------- 45

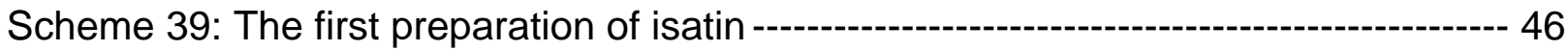


Scheme 40: Claisen and Shadwel isatin synthesis---_-_- 47

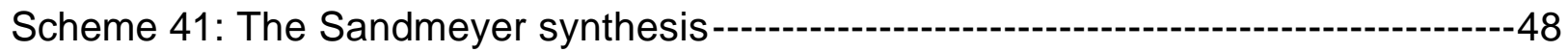

Scheme 42: Sandmeyer's diphenylurea isatin synthesis -----------------------------------48

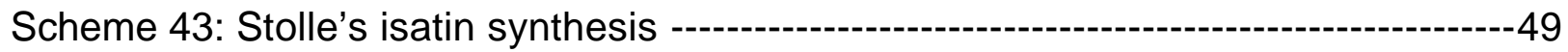

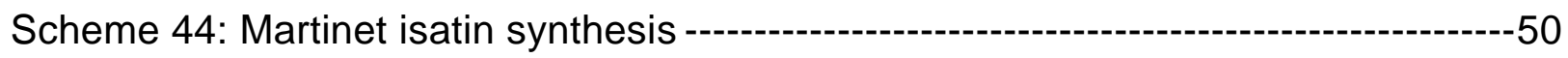

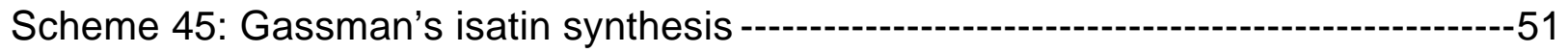

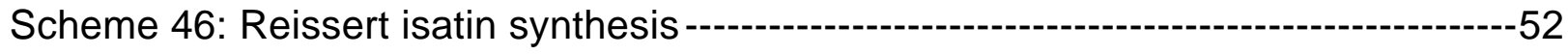

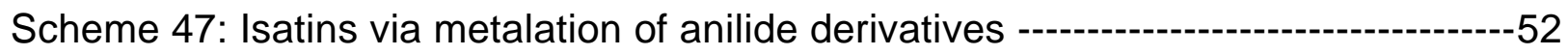

Scheme 48: Isatins via lithium assisted carbonylation -----------------------------------------53

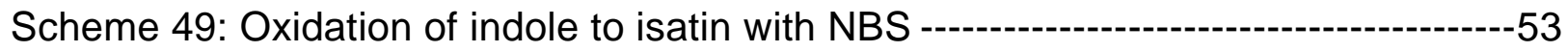

Scheme 50: Isatins via palladium-catalyzed double carbonylation -----------------------54

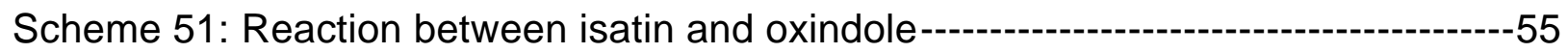

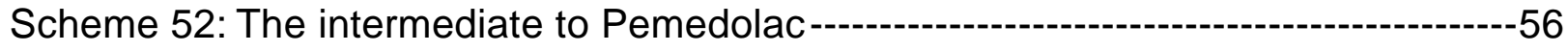

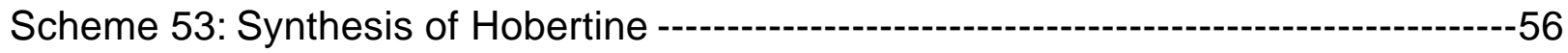

Scheme 54: The reaction between isatin and ammonia-----------------------------------57

Scheme 55: The reaction between $\mathrm{N}$-acetylisatin and ammonia ----------------------58

Scheme 56: The pyrrolo[1,4]benzodiazepine ring synthesis -----------------------------58

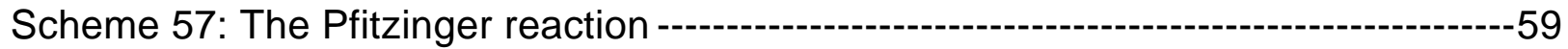

Scheme 58: The discovery of the palladium-catalyzed synthesis of isatin --------------60

Scheme 59: The reaction behind the necessity of palladium to catalyze the isatin formation-------------------------------------------------------------------------61

Scheme 60: The two step synthesis of 2-(2-bromoethynyl)-1-nitrobenzene (212a) --63

Scheme 61: Formation of the 2-iodo-5-methoxyisatogen (249), alongside the iodo-alkyne (217d) ------------------------------------------------64 
Scheme 62: Preparation of 5,6-methylenedioxyisatin (224) -------------------------------66

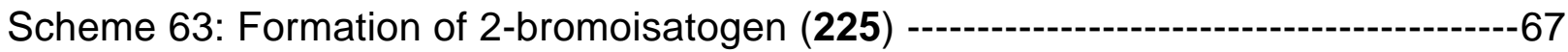

Scheme 64: Baeyer's synthesis of the "parent isatogen"---------------------------------67

Scheme 65: Stephen-Castro conditions and Sonagashira conditions leading to

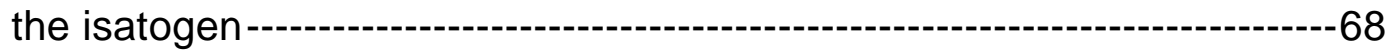

Scheme 66: Krohnke's isatogen synthesis --.--

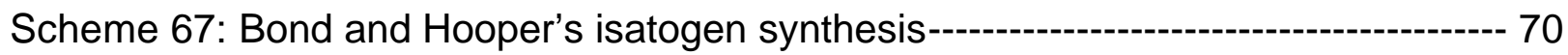

Scheme 68: Isatogen synthesis with Mimon's reagent---------------------------------------- 70

Scheme 69: Ring expansion reaction of 2-phenylisatogen with $\mathrm{NH}_{3}$-------------------71

Scheme 70: Ring expansion reactions of 2-phenylisatogen --------------------------------72

Scheme 71: The preparation of 2-bromo-5,6-methylenedioxyisatogen (248) ---------73

Scheme 72: The attempted auric bromide catalyzed reaction------------------------------ 73

Scheme 73: The one pot synthesis of 2-ethoxyisatogens $250 \mathrm{a}$ and $250 \mathrm{c}$

Scheme 74: Fischer indole synthesis of carbazolones -------------------------------------- 79

Scheme 75: Japp-Klingemann synthesis of the hydrazone 251; the substrate for the

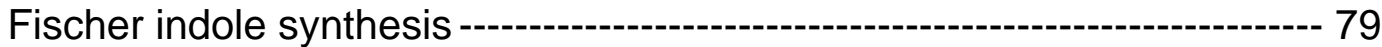

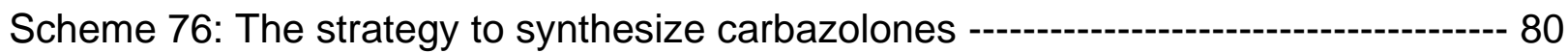

Scheme 77: The two isomeric carbazolones, $\mathbf{2 5 8 c}$ and $\mathbf{2 5 8 d}$ obtained via the Fischer indole synthesis---------------------------------------------------------------- 82

Scheme 78: The two isomeric tetrahydocarbazoles as reported by the Chakravorty group ------------------------------------------------------------------- 83

Scheme 79: Synthesis of $o$-hydroxydiarylamines by Makosza et. al---------------------- 84

Scheme 80: The "Makosza" group's experiments on acenathenone ------------------- 85

Scheme 81: The formation of 1-methyl-3-hydroxycarbazole (279) ----------------------- 86

Scheme 82: The plausible mechanistic pathway to the 3-hydroxycarbazole (283)----- 88 
Scheme 83: Synthesis of the indole fragment by the "Moody" group--------------------- 92

Scheme 84: Synthesis of the indole fragment by the Fisher indole synthesis ---------- 93

Scheme 85: Retrosynthesis of the indole fragment of nosiheptide ----------------------- 94

Scheme 86: Syntheses of the 2-halo-3-nitrobenzyl ethers, 307 and 299b -------------- 96

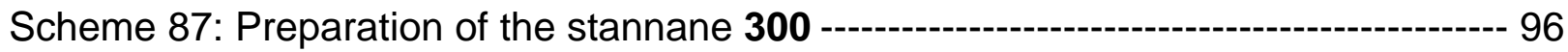

Scheme 88: Attempted stille coupling on 2-iodo-3-nitrobenzylmethylether (299b) and 2-iodo-3-nitromethylbenzoate (310) --------------------------------- 97

Scheme 89: Preparation of methyl-3-iodo-2(Z)-butenoate (313)-------------------------- 97

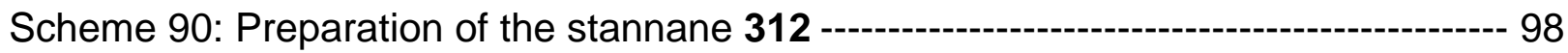

Scheme 91: The attempted stille coupling between the aryl stannane (312) and methyl-

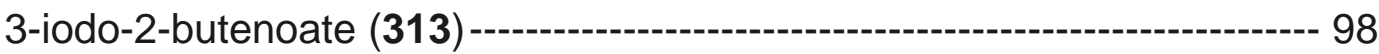

Scheme 92: Attempted Heck reaction between methyl-2-butenoate (316) and 2-iodo-3-nitrobenzylmethylether (299b) -------------------------------- 99

Scheme 93: The second retrosynthetic analysis of the indole fragment ---------------- 100

Scheme 94: Attempted syntheses of compound 318a -------------------------------- 101 


\section{List of Tables}

Table 1: Hemmetsberger-Knittel synthesis of $(5,5)$ fused pyrroloheterocycles---------- 8

Table 2: Thienopyrroles, as prepared by the Cadogan-Sundberg synthesis

Table 3: Examples of the $\mathrm{N}$-heterocyclic compounds synthesized with $5 \% \mathrm{Rh}$ (II) at $60{ }^{\circ} \mathrm{C}$

Table 4: Intramolecular Heck reaction in the synthesis of the three isomeric thienopyrroles

Table 5: Heteroannulation of the styrylthiophenes 104 and 107 29

Table 6: Conditions evaluated in affecting the cyclization of 3,4-dinitro,2-5distyrylthiophene (112) 30

Table 7: Heteroannulation conditions evaluated on 4-nitro-5-styryl-2-furanaldoxime (118)

Table 8: Heteroannulation of the styrylthiazole 126 under different catalytic conditions

Table 9: Preparation of the two isomeric pyrroloimidazoles, 133 and 134--------------- 35

Table 10: Attempted heteroannulation of 3-methyl-4-nitro-5-styrylisoxazole (137)----- 36

Table 11: Conditions evaluated in the synthesis of the precursor styrylpyrrole 142---- 38

Table 12: Attempted condensation of $\mathbf{1 4 7}$ with benzaldehyde --------------------------- 40

Table 13: Attempted condensation of $\mathbf{1 4 9}$ with benzaldehyde --------------------------- 40

Table 14: Attempted heteroannulation on N-methyl-3-nitro-4-(2-phenylethyl)pyrrole (156) and N-tosyl-3-nitro-4-(2-phenylethynyl)pyrrole (157) ------------------------- 42

Table 15: Optimization of the reaction conditions, as recorded by Chet Howerton----62

Table 16: The reaction conditions evaluated on 5-Methoxy-2-nitro-1-(2-iodoethynyl)

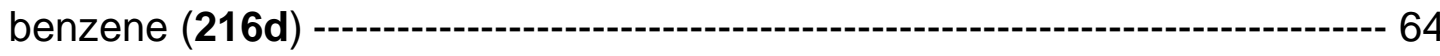


Table 17: The sequential conversion of 2-halonitrobenzenes to the corresponding

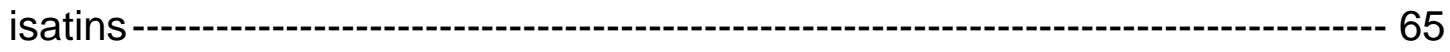

Table 18: Conditions evaluated in the preparation of 2-alkoxyisatogens ---------------75

Table 19: Carbazolones synthesized via palladium-catalyzed reductive

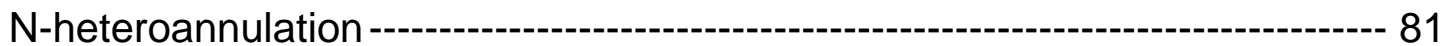

Table 20: Conditions evaluated in the synthesis of 3-hydroxycarbazole (283) --------- 87

Table 21: Conditions evaluated in the preparation of the aryl stannane (312)----------- 98 


\section{List of Figures}

Figure 1: Some examples of the $(5,5)$ fused pyrroloheterocyclic system ---------------- 2

Figure 2: Bioisosteric analogs of Tenidap----_- 3

Figure 3: Sodium 1-methyl-2-(4-Chlorobenzoyl)pyrrolo[2,3-d]imidazole-5-carboxylate (12) and sodium 4-(4-bromo-benzenesulphonyl)-pyrrolo[2,3-d]imidazole-5-

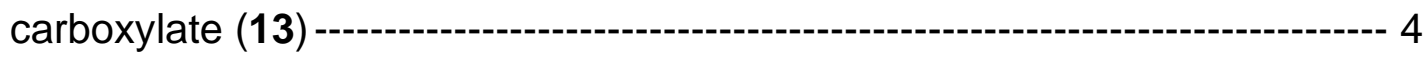

Figure 4: Blue M1 (14) and Blue M2 (15) --------------------------------------------------- 5

Figure 5: 1,3,4-Trimethylpyrrolo[3,2-b]pyrrole (16) and 1,2,4-trimethylpyrrolo[3,2-b]

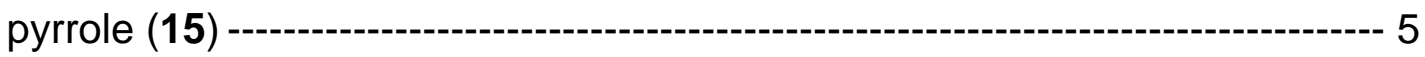

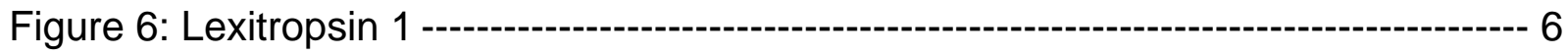

Figure 7: The hypothetical palladium-bound nitrene intermediate ------------------------ 23

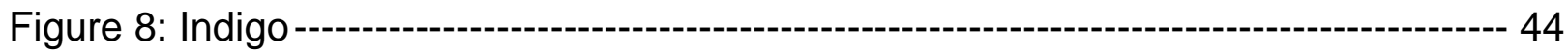

Figure 9: The two proposed structures of isatin by Baeyer----------------------------- 45

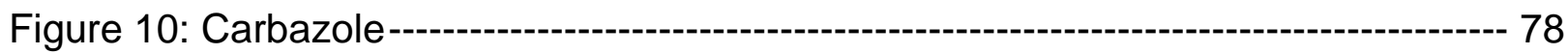

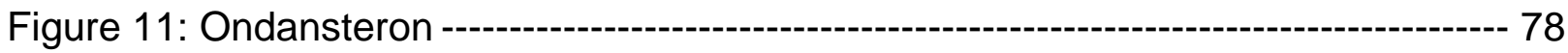

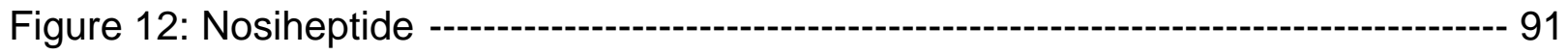

Figure 13: ${ }^{1} \mathrm{H}$ NMR Spectrum of Compound 108

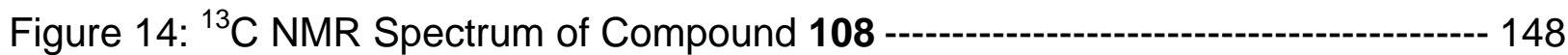

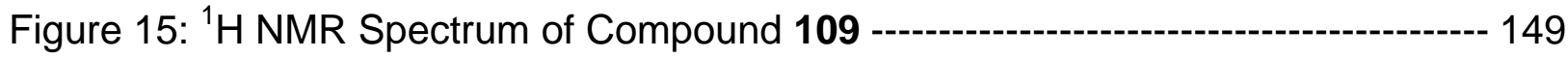

Figure 16: ${ }^{13} \mathrm{C}$ NMR Spectrum of Compound 109 --- 150

Figure 17: ${ }^{1} \mathrm{H}$ NMR Spectrum of Compound 112

Figure 18: ${ }^{13} \mathrm{C}$ NMR Spectrum of Compound 112

Figure 19: ${ }^{1} \mathrm{H}$ NMR Spectrum of Compound 113 
Figure 20: ${ }^{13} \mathrm{C}$ NMR Spectrum of Compound 113 --- 154

Figure 21: ${ }^{1} \mathrm{H}$ NMR Spectrum of Compound 114 -------------------------------- 155

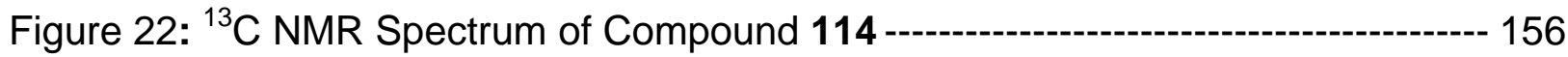

Figure 23: ${ }^{1} \mathrm{H}$ NMR Spectrum of Compound 118

Figure 24: ${ }^{13} \mathrm{C}$ NMR Spectrum of Compound 118 ------------------------------- 158

Figure 25: ${ }^{1} \mathrm{H}$ NMR Spectrum of Compound 119

Figure 26: ${ }^{1} \mathrm{H}$ NMR Spectrum of Compound 120

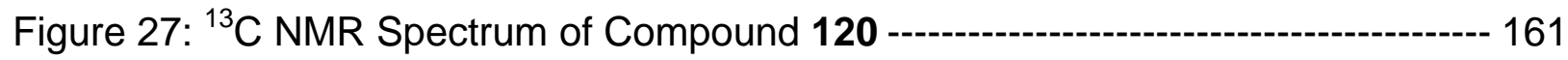

Figure 28: ${ }^{1} \mathrm{H}$ NMR Spectrum of Compound 127

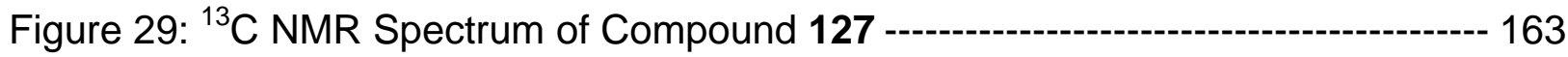

Figure 30: ${ }^{1} \mathrm{H}$ NMR Spectrum of Compound 133

Figure 31: ${ }^{13} \mathrm{C}$ NMR Spectrum of Compound 133 ------------------------------------ 165

Figure 32: ${ }^{1} \mathrm{H}$ NMR Spectrum of Compound 134

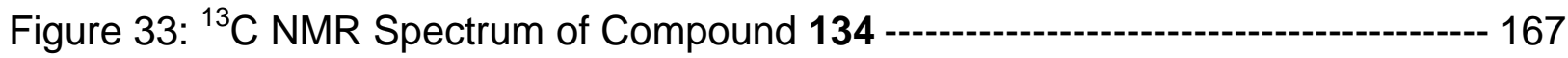

Figure 34: ${ }^{1} \mathrm{H}$ NMR Spectrum of Compound 141

Figure 35: ${ }^{13} \mathrm{C}$ NMR Spectrum of Compound 141

Figure 36: ${ }^{1} \mathrm{H}$ NMR Spectrum of Compound 157 -----o- 170

Figure 37: ${ }^{13} \mathrm{C}$ NMR Spectrum of Compound 157 ------ 171

Figure 38: ${ }^{1} \mathrm{H}$ NMR Spectrum of Compound 216a------------------------------------- 172

Figure 39: ${ }^{13} \mathrm{C}$ NMR Spectrum of Compound 216a------ 173

Figure 40: ${ }^{1} \mathrm{H}$ NMR Spectrum of Compound 216b ------------------------------------- 174

Figure 41: ${ }^{13} \mathrm{C}$ NMR Spectrum of Compound 216b ---------------------------------- 175

Figure 42: ${ }^{1} \mathrm{H}$ NMR Spectrum of Compound 216c----------------------------------- 176 
Figure 43: ${ }^{13} \mathrm{C}$ NMR Spectrum of Compound 216c---- 177

Figure 44: ${ }^{1} \mathrm{H}$ NMR Spectrum of Compound 216d ------------------------------- 178

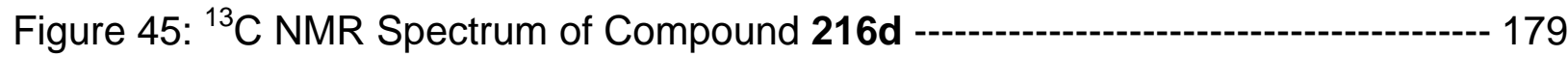

Figure 46: ${ }^{1} \mathrm{H}$ NMR Spectrum of Compound 216e------- 180

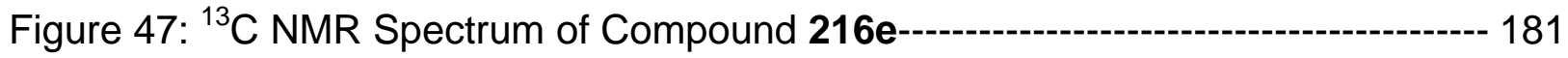

Figure 48: ${ }^{1} \mathrm{H}$ NMR Spectrum of Compound $216 \mathrm{~g}-$

Figure 49: ${ }^{13} \mathrm{C}$ NMR Spectrum of Compound 216g --- 183

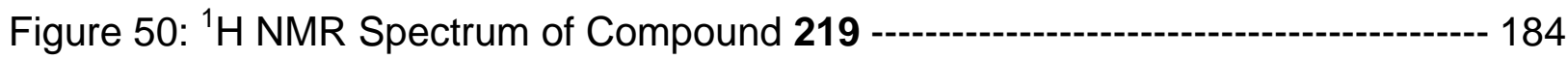

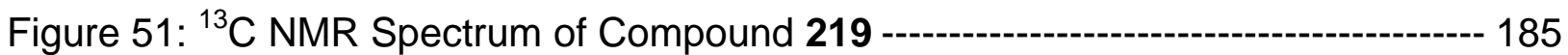

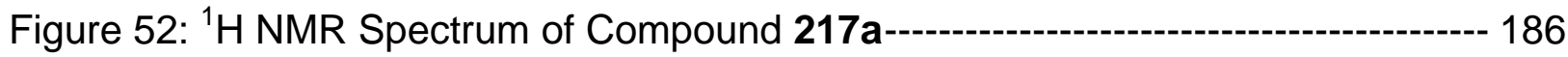

Figure 53: ${ }^{13} \mathrm{C}$ NMR Spectrum of Compound 217a------- 187

Figure 54: ${ }^{1} \mathrm{H}$ NMR Spectrum of Compound 217b--------------------------------------- 188

Figure 55: ${ }^{13} \mathrm{C}$ NMR Spectrum of Compound 217b --- 189

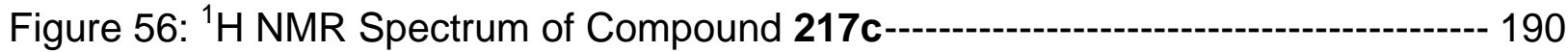

Figure 57: ${ }^{13} \mathrm{C}$ NMR Spectrum of Compound 217c---------------------------------- 191

Figure 58: ${ }^{1} \mathrm{H}$ NMR Spectrum of Compound 217d ----- 192

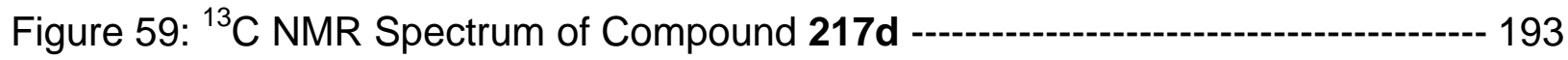

Figure 60: ${ }^{1} \mathrm{H}$ NMR Spectrum of Compound 217e---_---- 194

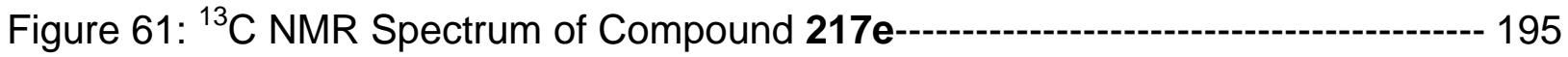

Figure 62: ${ }^{1} \mathrm{H}$ NMR Spectrum of Compound 217f ----- 196

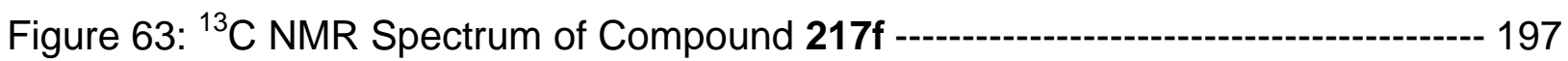

Figure 64: ${ }^{1} \mathrm{H}$ NMR Spectrum of Compound 217g------------------------------------- 198

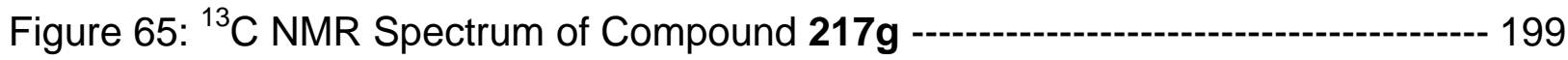


Figure 66: ${ }^{1} \mathrm{H}$ NMR Spectrum of Compound 220

Figure 67: ${ }^{13} \mathrm{C}$ NMR Spectrum of Compound 220 -------------------------------- 201

Figure 68: ${ }^{1} \mathrm{H}$ NMR Spectrum of Compound 222

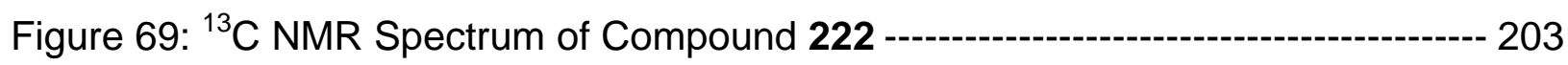

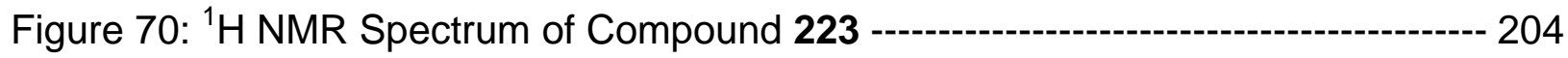

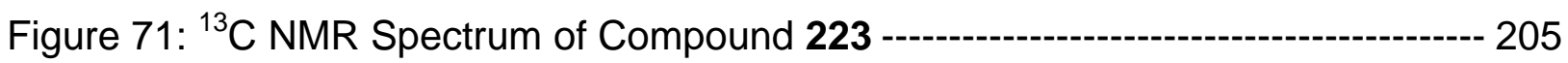

Figure 72: ${ }^{1} \mathrm{H}$ NMR Spectrum of Compound 164a--- 206

Figure 73: ${ }^{13} \mathrm{C}$ NMR Spectrum of Compound 164a----------------------------------- 207

Figure 74: ${ }^{1} \mathrm{H}$ NMR Spectrum of Compound 164b ----- 208

Figure 75: ${ }^{13} \mathrm{C}$ NMR Spectrum of Compound 164b ------------------------------- 209

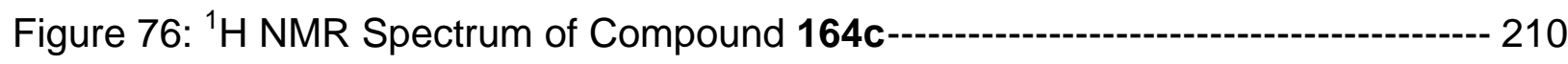

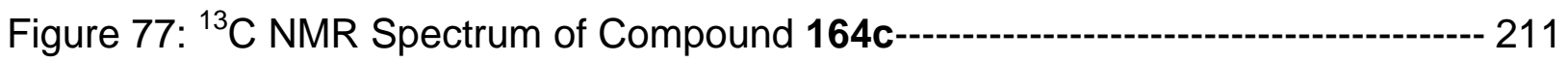

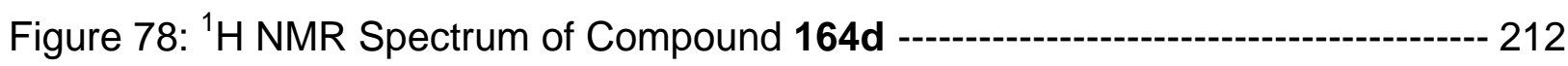

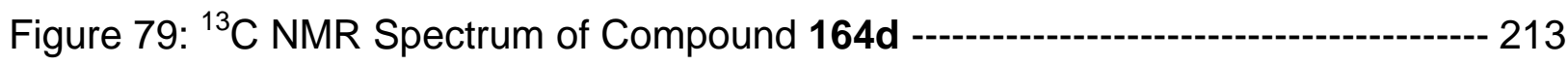

Figure 80: ${ }^{1} \mathrm{H}$ NMR Spectrum of Compound 164e------------------------------------------- 214

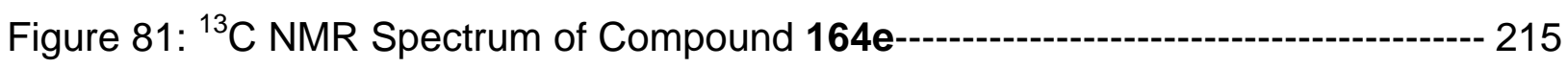

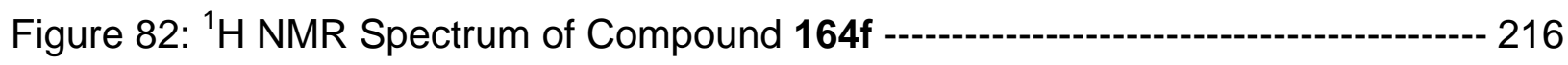

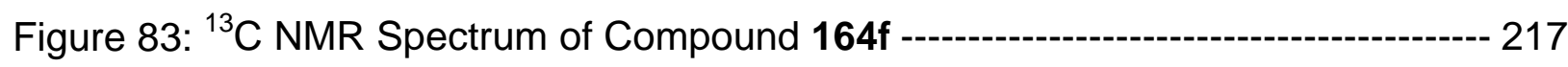

Figure 84: ${ }^{1} \mathrm{H}$ NMR Spectrum of Compound $164 \mathrm{~g}$-------------------------------- 218

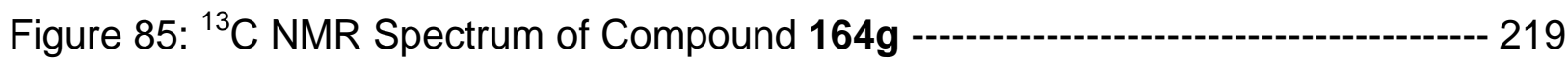

Figure 86: ${ }^{1} \mathrm{H}$ NMR Spectrum of Compound 224 --------------------------------------------- 220

Figure 87: ${ }^{13} \mathrm{C}$ NMR Spectrum of Compound 224 ------------------------------------- 221

Figure 88: ${ }^{1} \mathrm{H}$ NMR Spectrum of Compound 248 
Figure 89: ${ }^{13} \mathrm{C}$ NMR Spectrum of Compound 248

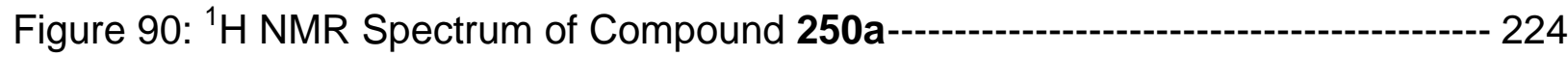

Figure 91: ${ }^{13} \mathrm{C}$ NMR Spectrum of Compound 250a--------------------------------------- 225

Figure 92: ${ }^{1} \mathrm{H}$ NMR Spectrum of Compound 250c- 226

Figure 93: ${ }^{13} \mathrm{C}$ NMR Spectrum of Compound 250c------------------------------- 227

Figure 94: ${ }^{1} \mathrm{H}$ NMR Spectrum of Compound 251

Figure 95: ${ }^{1} \mathrm{H}$ NMR Spectrum of Compound 251 (Expanded) ----------------------------- 229

Figure 96: ${ }^{1} \mathrm{H}$ NMR Spectrum of Compound 251 (Expanded) ---------------------- 230

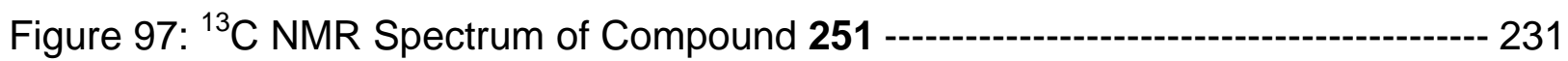

Figure 98: ${ }^{1} \mathrm{H}$ NMR Spectrum of Compound 279 ---------------------------------- 232

Figure 99: ${ }^{1} \mathrm{H}$ NMR Spectrum of Compound 279 (Expanded Aromatic Region) ------- 233

Figure 100: ${ }^{13} \mathrm{C}$ NMR Spectrum of Compound 279-------------------------------------- 234

Figure 101: ${ }^{1} \mathrm{H}$ NMR Spectrum of Compound 308------ 235

Figure 102: ${ }^{1} \mathrm{H}$ NMR Spectrum of Compound 308 (Expanded Aromatic Region) ----- 236

Figure 103: ${ }^{1} \mathrm{H}$ NMR Spectrum of Compound 308 (Expanded and Assigned) --------- 237

Figure 104: ${ }^{13} \mathrm{C}$ NMR Spectrum of Compound 308--- 338

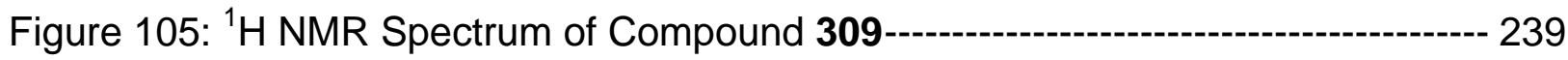

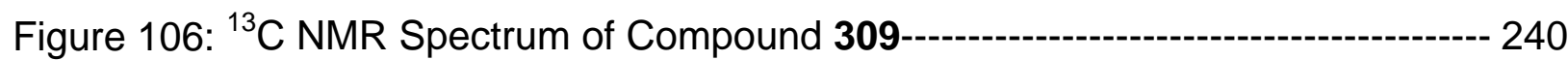

Figure 107: ${ }^{1} \mathrm{H}$ NMR Spectrum of Compound 299b------------------------------------- 241

Figure 108: ${ }^{13} \mathrm{C}$ NMR Spectrum of Compound 299b---- 242 


\section{Chapter 1}

\section{Syntheses of Fused Pyrroloheterocycles}

\subsection{Introduction:}

Aromatic ring systems with at least one heteroatom fused to a pyrrole nucleus are defined as "fused bicyclic pyrrloheterocycles". These compounds belong to a class of nitrogen heterocycles that have been of interest to many researchers for over half a century. The interest in these ring systems stems from their isosteric relationship to indole and their presence as the structural components in many biologically active compounds. Among the several possible fused bicyclic pyrroloheterocycles, those that belong to the fused $(5,5)$ category are the subjects under study in this chapter. Thienopyrroles, furopyrroles and pyrrolopyrroles belong to the A,B-diheteropentalene ${ }^{1}$ system under this classification of compounds. Pyrroloimidazoles, pyrrolothiazoles, pyrroloisoxazoles and pyrroloisothiazoles, are some of the examples of ring systems with three heteroatoms from the $(5,5)$ fused class of compounds (Figure 1 ). 
<smiles>c1cc2sccc2[nH]1</smiles>

1a. Thieno[3,2-b]pyrrole<smiles>c1cc2occc2[nH]1</smiles>

1d. Furo[3,2-b]pyrrole<smiles>c1cc2ncsc2[nH]1</smiles>

1g. Pyrrolo[3,2-d]thiazole<smiles>[R]n1cnc2[nH]ccc21</smiles>

1j. Pyrrolo[3,2-d]imidazole<smiles>c1cc2ccsc2[nH]1</smiles>

1b. Thieno[2,3-b]pyrrole<smiles>[R]n1ccc2[nH]ccc21</smiles>

1e. Pyrrolo[3,2-b]pyrrole<smiles>c1cc2scnc2[nH]1</smiles>

1h. Pyrrolo[2,3-d]thiazole<smiles>[R]n1cnc2cc[nH]c21</smiles>

1k. Pyrrolo[2,3-d]imidazole<smiles>c1cc2ccoc2[nH]1</smiles>

1c. Furo[2,3-b]pyrrole<smiles>[R]n1ccc2cc[nH]c21</smiles>

1f. Pyrrolo[2,3-b]pyrrole<smiles>c1cc2[nH]cc-2on1</smiles>

1i. Pyrrolo[2,3-d]isoxazole

\section{Figure 1: Some examples of the $(5,5)$ fused pyrroloheterocyclic system}

Thienopyrrole subunits are found in several biologically active compounds used in the treatment of inflammation, viral infections and CCK antagonists, as well as in inhibitors of glycogen phosphorylase, cyclooxygenase, lipoxygenase, MCP-1 and biosteric analogs of serotonin agonist N,N-dimethyltryptamine. Bioisosteres of Tenidap, Tenoxicam and Lornoxicam, obtained by replacing the benzene ring with thiophene gave the analogous compounds 2, 3, 4 which were found to exhibit anti-inflammatory activity against rat-paw edema. ${ }^{2}$ 


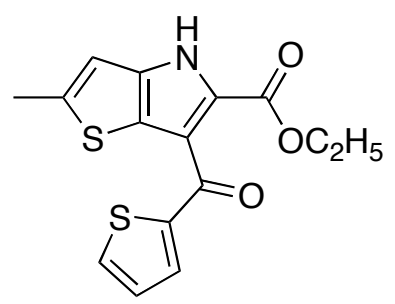

2

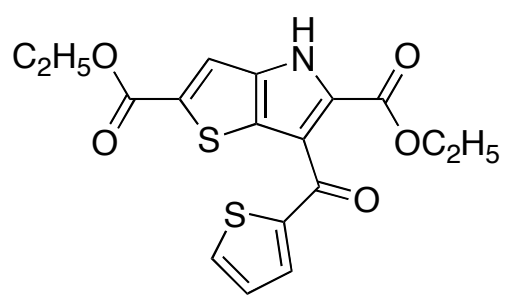

3

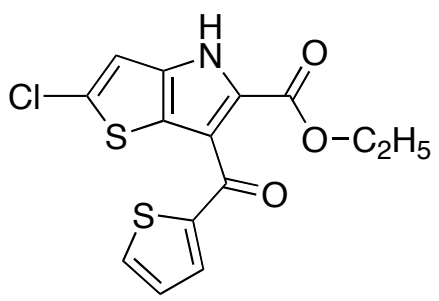

4

Figure 2: Bioisosteric analogs of Tenidap

With furan and its derivatives categorized as the most studied five membered heteroring system for the Diels-Alder reaction, furo[3,2-b]pyrroles and the isomeric furo[2,3b]pyrroles have become potential synthetic targets. A glance at the extensive work on these compounds by Krutosikova and his group depict the popularity of these compounds. Many of the compounds prepared by the Krutosikova group were tested for their carcinogenic activity. ${ }^{3}$ Additional studies on these compounds by the same researchers show that they react with dimethylbutynedioate (6) to form substituted indoles 8. The formation of these substituted indoles was attributed to a [4+2] cycloaddition on the furan ring followed by a facile ring opening of an undetected adduct 7. ${ }^{4}$ A similar reaction was observed with ethyl propynoate (9), an unsymmetrical dienophile, and this reaction gave a mixture of the two possible isomers 10 and $\mathbf{1 1}$ (Scheme 1). 

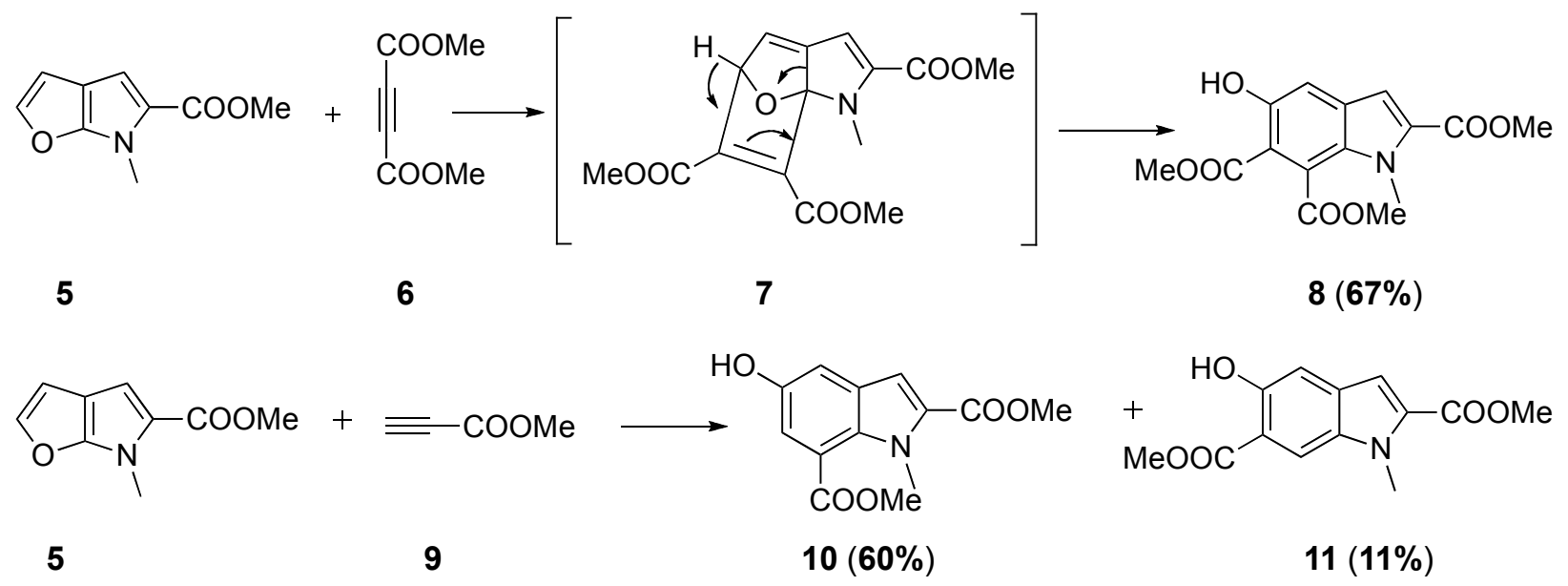

Scheme 1: [4+2]cycloaddition to a furo[2,3-b]pyrrole

Several pyrrolo[2,3-d]imidazole-5-carboxylate derivatives were synthesized and tested for their anti-inflammatory activity against carrageenan-induced rat hindpaw. The 4chlorobenzoyl derivative 12 displayed almost thrice the potency of aspirin (Figure 3) and sodium 4-(4-bromo-benzenesulphonyl)-pyrrolo[2,3-d]imidazole-5-carboxylate (13), a little less anti-inflammatory activity than indomethacin. ${ }^{5}$

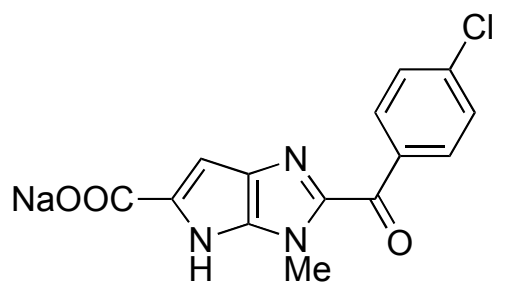

12

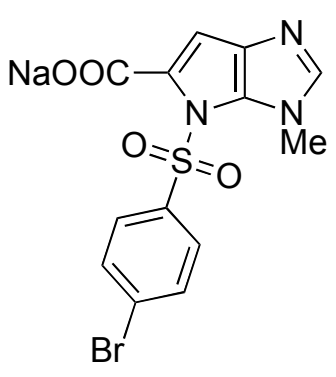

13

Figure 3: Sodium 1-methyl-2-(4-Chlorobenzoyl)pyrrolo[2,3-d]imidazole-5carboxylate (12) and sodium 4-(4-bromo-benzenesulphonyl)-pyrrolo[2,3d]imidazole-5-carboxylate (13)

The pyrrolopyrrole scaffold has been found in the blue M1 and M2 pigments (Figure 4). These compounds have been identified during the "Mailard reaction" between D- 
xylose and glycine and were suggested to be Maillard reaction intermediates through the formation of melanoidins. ${ }^{6}$<smiles></smiles>

14<smiles></smiles>

Figure 4: Blue M1 (14) and Blue M2 (15)

1,3,4-Trimethyl and 1,2,4-trimethylpyrrolo[3,2-b]pyrroles (Figure 5) have received considerable attention as candidates for electropolymerization. Their polymeric films have been prepared and found to have electrochromic property. ${ }^{7}$

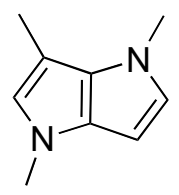

16

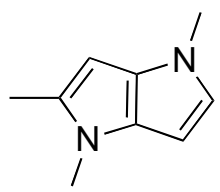

17

Figure 5: 1,3,4-Trimethylpyrrolo[3,2-b]pyrrole (16) and 1,2,4-trimethylpyrolo[3,2-b] pyrrole (17)

Pyrrolo[3,2-d]thiazoles have been reported as anti-phlogistic pharmaceuticals and immunomodulators, ${ }^{8}$ inhibitors and anticoagulants for the prevention and treatment of 
thrombosis and embolism, ${ }^{9}$ and as components of photomaterials. ${ }^{10}$ Lexitropsins form a group of synthetically designed compounds that have been examined for their DNA binding activity. ${ }^{11}$

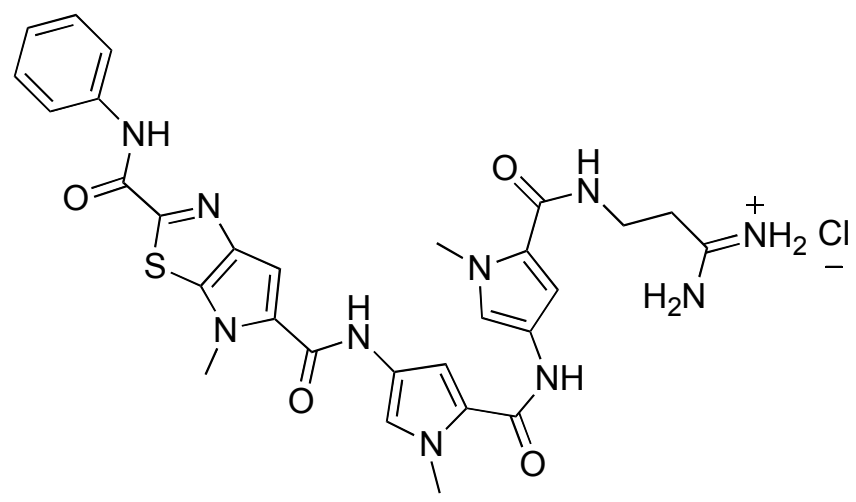

\section{Figure 6: Lexitropsin 1}

\subsection{Notable synthetic routes to $(5,5)$ fused pyrroloheterocyclic compounds:}

With the ubiquitous acceptance of pyrroloheterocycles as indole isosteres, it is not unusual to speculate the applicability of "indole syntheses" to these compounds. Despite the plethora of the synthetic pathways, most of the routes available to synthesize indole and indole-derivatives were unfavorable to the $(5,5)$ fused pyrroloheterocycles. The reason could be attributed to either the lack of availability of suitable starting materials or to low yields of the respective products.

\section{2 (a) Hemmetsberger-Knittel synthesis:}

Among the favored syntheses was the "Hemetsberger synthesis"12, which features the thermolysis of an intermediate aryl azido acrylate as the key step to construct the "pyrrole ring". Two examples reported by Garcia and Galvez forming a thieno[3,2b]pyrrole and a thieno[2,3-b]pyrrole are shown in Scheme $2 .{ }^{13}$ The aryl azido acrylates 
(20 \& 23) are prepared from the Knoevenagel condensation between the aromatic aldehydes (18 \& 22) and an azido ester (19)<smiles>[R]c1ccc(C=O)s1</smiles>

21(a) $\mathrm{R}=\mathrm{H}, \mathbf{9 1 \%}$

(b) $\mathrm{R}=\mathrm{Br}, \mathbf{9 5 \%}$

(c) $\mathrm{R}=\mathrm{NO}_{2}, 34 \%$<smiles>[R]c1cc(C=O)cs1</smiles>

22<smiles>CCOC(=O)CN(C)OC</smiles>

19<smiles>[R]OC(=O)/C(N)=C/c1csc([Y10])c1</smiles>

23<smiles>[R]c1cc2cc(C(=O)OCC)[nH]c2s1</smiles>

24 (a) $\mathrm{R}=\mathrm{H}, \mathbf{8 7 \%}$

(b) $\mathrm{R}=\mathrm{Br}, \mathbf{7 3} \%$

(c) $\mathrm{R}=\mathrm{NO}_{2}, 8 \%$

Scheme 2: Hemmetsberger-Knittel synthesis of the thieno[3,2-b]pyrrole and thieno[2,3-b]pyrrole

This reaction can be formally seen as going through a nitrene intermediate $\mathbf{2 7}$, which subsequently inserts into the $\mathrm{C}-\mathrm{H}$ bond of the arene. However, the isolation of azirine intermediates $(26)$ at lower temperatures $\left(80^{\circ} \mathrm{C}\right)$ suggests that this reaction also proceeds through the formation of azirine (Scheme 3 ). ${ }^{14}$

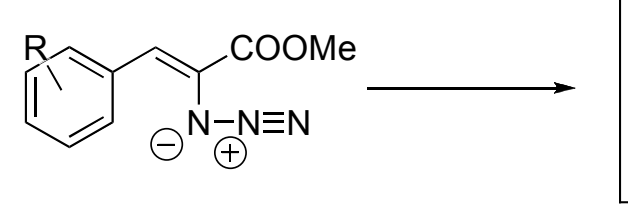

25<smiles>CC(=O)C1NC1c1ccccc1</smiles>
26 (a) $\mathrm{R}=\mathrm{H}(15 \%)$
(b) $\mathrm{R}=4-\mathrm{Me}(\mathbf{7 4 \%})$
(c) $\mathrm{R}=4-\mathrm{Cl}(54 \%)$

Scheme 3: The azirine intermediates isolated by Knittel en route to indole-2-carboxylates. 
With this result, it is assumed that there is an equilibrium between the azirine (26) and the nitrene (27) (Scheme 4).

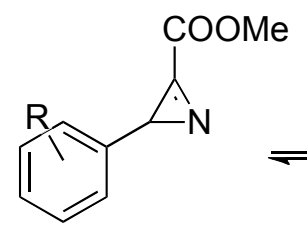

26<smiles>C=[W]/C(=C/c1ccccc1)C(=O)O[Na]</smiles>

27

\section{Scheme 4: Equilibrium between the nitrene and the azirine}

By far the Hemmetsberger-Knittel synthesis has been the major reaction utilized to synthesize several furo[2,3-b]pyrrole and the furo[3,2-b]pyrrole derivatives. ${ }^{15}$ Analogous to the furopyrroles, the construction of both the isomeric pyrroloimidazole rings was carried out by this reaction (Entry 9 and 10, Table 1 ). ${ }^{16}$ The 1,3,4-trimethyl and 1,2,4trimethylpyrrolo[3,2-b]pyrroles, ${ }^{7}$ thieno[3,2-b:4,5-b']dipyrrole ${ }^{17}$ (Entry 1, Table 1), pyrrolo[2,3-b]pyrrole dicarboxylate (Entry 8, Table 1), seleno[3,2-b]pyrrole-2-carboxylate (Entry 7, Table 1), seleno[2,3-b]pyrrole-2-carboxylate (Entry 6, Table 1) and furo[2,3b]pyrrole-2-carboxylate (Entry 4, Table 1$)^{18}$ were also synthesized by the same method.

Table 1: Hemmetsberger-Knittel synthesis of $(5,5)$ fused pyrroloheterocycles

\begin{tabular}{llll}
\hline Entry & The Aldehyde & Yield \\
\hline 1 & & \\
\hline
\end{tabular}




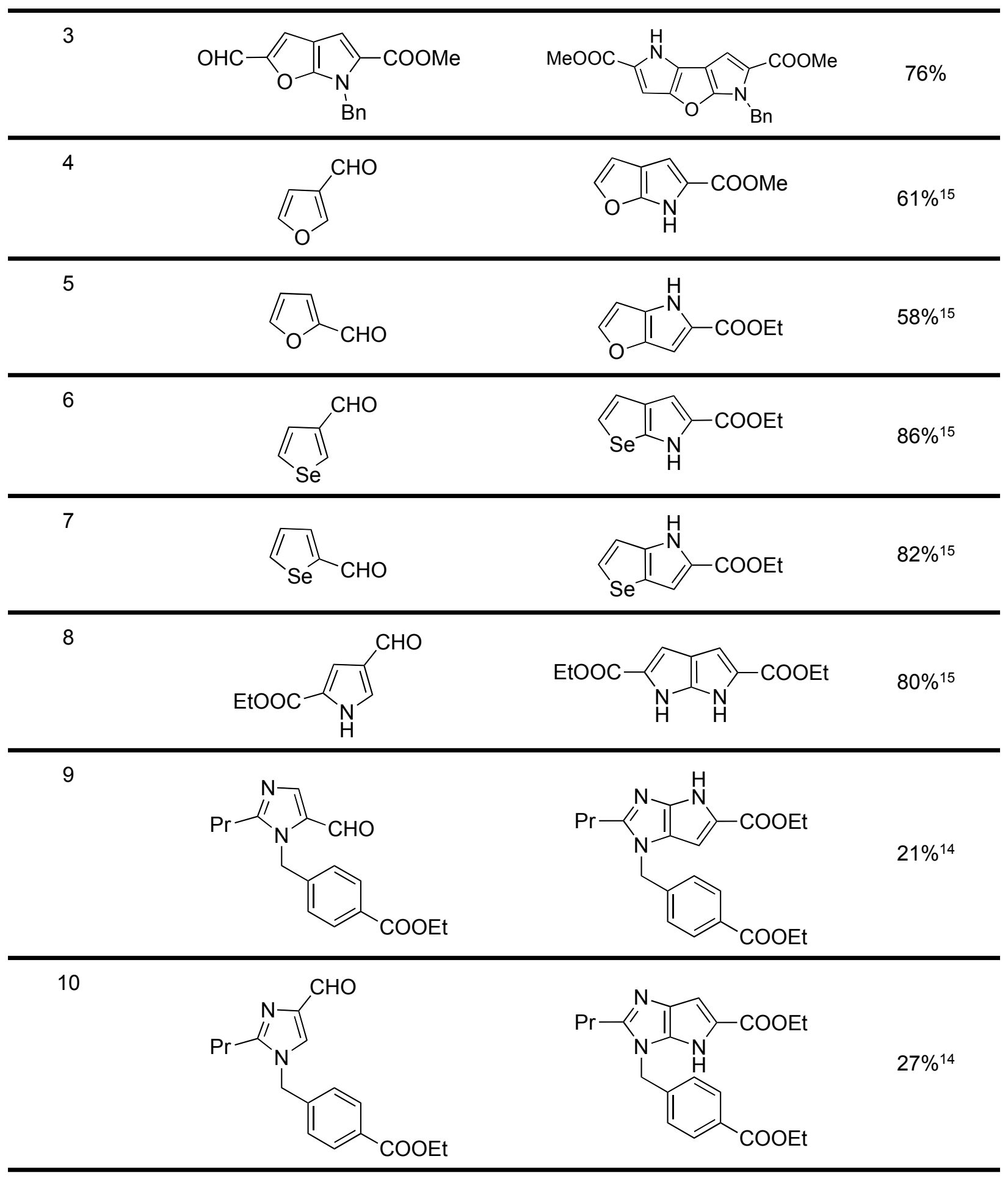




\section{2 (b) The Fischer indole synthesis:}

The "Fischer indole synthesis", ${ }^{19}$ developed in 1883 remains a popular reaction to construct the indole nucleus even today. Despite its fame, the use of Fischer indole synthesis in the construction of pyrroloheterocycles has been sparse. ${ }^{20,21}$ The essence of this reaction is an acid assisted sigmatropic rearrangement of an aryl hydrazone, formed from the condensation of a ketone with the arylhydrazine. An example ${ }^{21}$ of a "Fischer indole synthesis" in the preparation of a thieno[2,3-b]pyrrole derivative (31) from 2-butanone (22) and N-t-butoxycarbonyl-N-2-thienylhydrazine (29) is represented in Scheme 5.

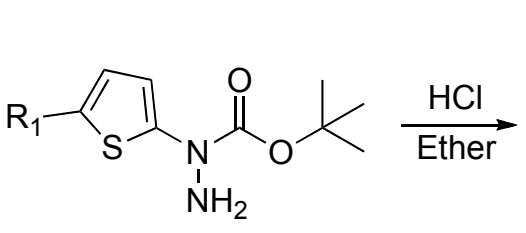

28

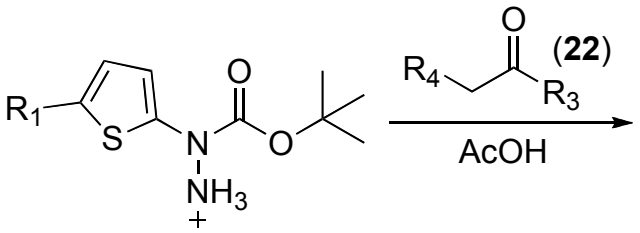

29<smiles>[R4]CC([R3])=NN(C(=O)OC(C)(C)C)c1ccc([R])s1</smiles>

30

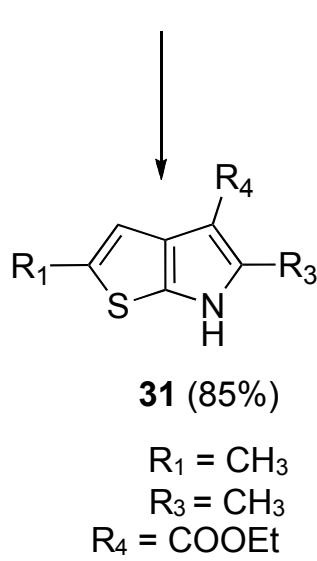

Scheme 5: The synthesis of a thieno[2,3-b]pyrrole via Fischer's indole synthesis

\section{2 (c) Batcho-Leimgruber synthesis:}

The two-step Batcho-Leimgruber indole synthesis ${ }^{22}$ provides a major alternative to Fisher's indole synthesis. In spite of the popularity in indole synthesis, there has been 
only one report on the applicability of the Batcho-Leimgruber synthesis in the synthesis of a thieno[3,2-b]pyrrole. A base catalyzed formation of an enamine (33) from 5methyl-4-nitrothiophene-2-carboxylic acid (32) and N,N-dimethylformamide dimethyl acetal (DMF-DMA) forms the first step of this reaction. This step is followed by the reductive cyclization of the enamine to afford the desired thieno[3,2-b]pyrrole (34) as the product (Scheme 6). ${ }^{23}$

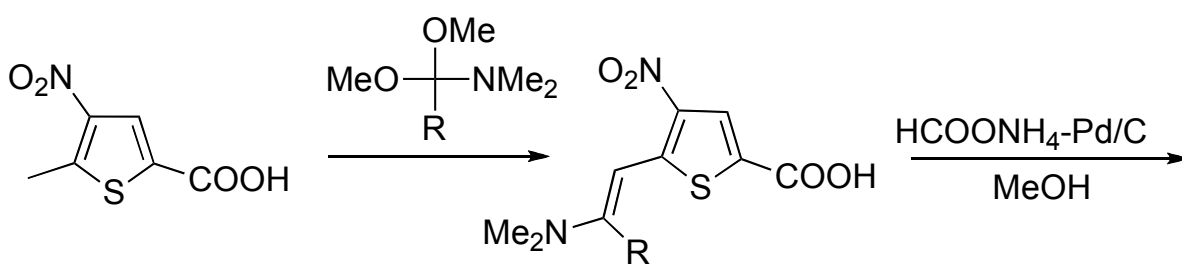

32
33

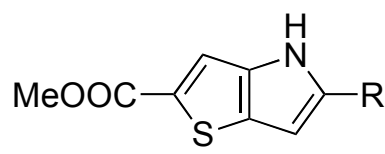

34 (a) $(\mathrm{R}=\mathrm{H}, 71 \%)$

(b) $(\mathrm{R}=\mathrm{Me}, 72 \%)$

\section{Scheme 6: Batcho-Liemgruber synthesis}

\section{2 (d) Sundberg synthesis:}

Another synthetic route to furo-, thieno- and seleno[3,2-b]pyrroles from substituted thiophenes, furans and selenophenes that displays the versatility of azides was reported by Salo Gronowitz et al. ${ }^{24}$ The reaction, referred to as "Sundberg synthesis" was performed earlier on substituted benzaldehydes to synthesize indoles. ${ }^{25}$ The Sundberg synthesis utilizes the thermal decomposition of azidoalkenylarenes $\mathbf{3 6}$ to form the corresponding products $\mathbf{3 8}$. The azido compounds required for this synthesis were prepared by 'aldol' condensation of an azidoaldehyde (35) (Scheme 7). 
散

35

36

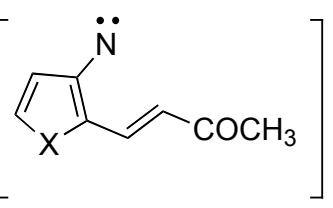

37<smiles>[X]c1cc2[nH]c(C(C)=O)cc2cc1C</smiles>

38 (a) $(X=0,69 \%)$

(b) $(X=S, 90 \%)$

(c) $(X=\mathrm{Se}, 82 \%)$

Scheme 7: The preparation of furo-, thieno- and seleno[3,2-b]pyrroles by the Sundberg reaction.

This reaction is mechanistically regarded as an insertion of the intermediate nitrene (37) into a $\mathrm{C}-\mathrm{H}$ bond to give the intermediate (37a) followed by a $6 \pi$ electrocyclization to generate the fused heterocycle (38) (Scheme 8).<smiles></smiles>

$36 a$

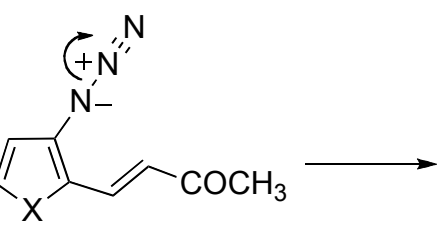

$36 b$

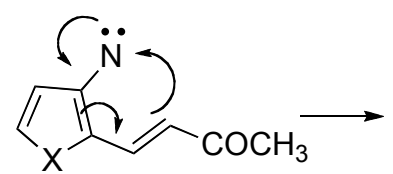

37<smiles></smiles>

$37 a$<smiles></smiles>

38

Scheme 8: Plausible mechanism of the Sundberg reaction

\section{2 (e) Cadogan-Sundberg synthesis:}

Another versatile indole synthesis that also involves a nitrene intermediate is the Cadogan-Sundberg synthesis. ${ }^{26,27}$ The generation of the nitrene in this reaction is carried out through a trialkyl phosphite assisted reductive deoxygenation of the corresponding o-nitroalkenylarene (39). The nitrene intermediate could be imagined to 
have formed from a nucleophillic attack of the phosphite on the nitro group of $\mathbf{3 9}$, leading to the intermediate (40). Subsequent loss of triethyl phosphate to form the nitroso compound (43), followed by another similar addition and elimination would produce the nitrene intermediate (47). Insertion of the nitrene into the $\mathrm{C}-\mathrm{H}$ bond, as suggested in the Sundberg synthesis would generate the required product 48 (Scheme 10). Successful applications of this reaction with respect to pyrroloheterocycles include 5-arylthieno[3,2-b]pyrrole and 5-arylthieno[2,3-b]pyrrole ${ }^{28,29}$ as well as their respective parent thienopyrroles (Table 2). ${ }^{30}$

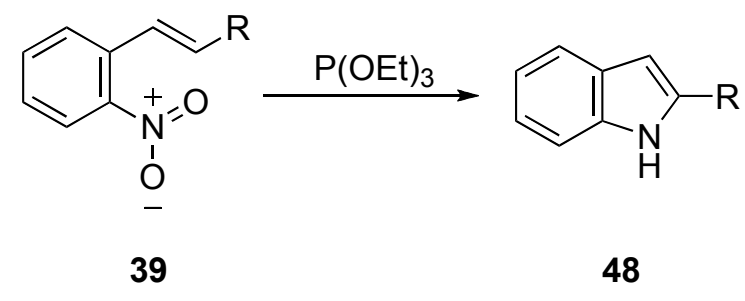

Scheme 9: General reaction for the Cadogan-Sundberg synthesis

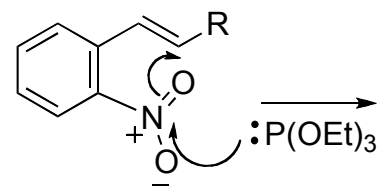

39<smiles>[R]OP1(OCC)(OCC)C=Cc2ccccc2ON1</smiles>

45<smiles>[R]C=Cc1ccccc1[N+]([O-])([O-])[P+]([O-])(OCC)OCC</smiles>

40<smiles>[R]C=Cc1ccccc1N(C)[P+](CC)(OCC)OCC</smiles>

44<smiles>[R]C=Cc1ccccc1[N+](=O)[N+]([O-])(OCC)P(=O)(OCC)OCC</smiles>

41<smiles>[R]COP(OCC)(OCC)(OCC)N1CO1</smiles>

42<smiles>[R]CCP(OCC)(OCC)(OCC)OCC1c2ccccc2N(CCC)CC1[R]</smiles>

46

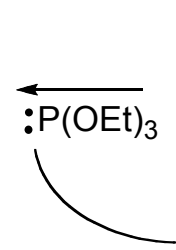<smiles>C=CC=C</smiles><smiles>[R]C=Cc1ccccc1N1CCO1</smiles>

43

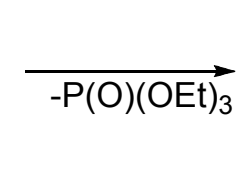<smiles>[R]c1cc2ccccc2[nH]1</smiles>

47

48

Scheme 10: Plausible mechanism for the Cadogan-Sundberg reaction 
Table 2: Thienopyrroles, as prepared from Cadogan-Sundberg synthesis

Entry Substrate

\section{2 (f) Snyder's synthetic approaches to thienopyrroles:}

Among the numerous syntheses of the thienopyrrole scaffold by various researchers, the synthetic efforts of Snyder and his co-workers deserve to be mentioned. The earliest report by the Snyder group was an application of the Reissert indole synthesis ${ }^{31}$ in the synthesis of the parent thieno[3,2-b]pyrrole (55). With a slight modification of the Reissert indole synthesis, the Snyder group synthesized the parent thieno[3,2-b]pyrrole (55) through the intermediate pyruvic acid (53), that was prepared from 2-methyl-3-nitrothiophene (49) via an azlactone (52). The pyruvic acid (53) was then subjected to reductive cyclization in presence of aqueous $\mathrm{NH}_{3}$ and ferrous sulphate to afford the thienopyrrole carboxylic acid (54). Decarboxylation of 54 gave the thieno[3,2b]pyrrole (55), which proved to be unstable when exposed to air (Scheme 11). ${ }^{32}$ 
A similar reaction sequence, when employed to synthesize the isomeric thieno[2,3b]pyrrole, resulted in it's decomposition prior to purification.

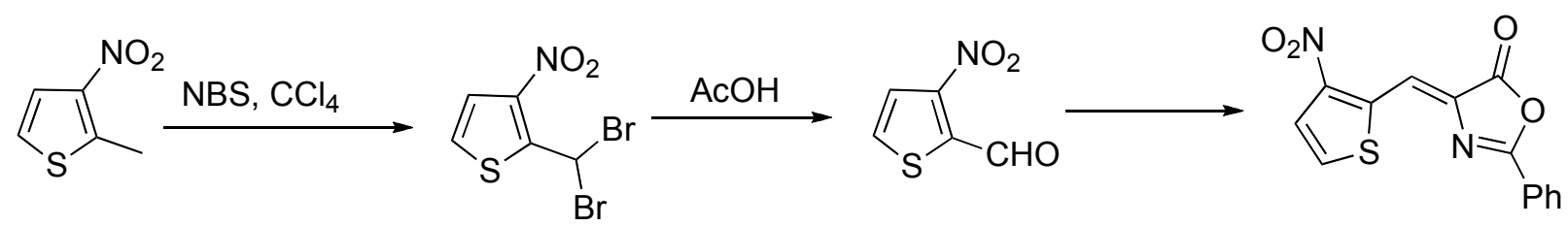

49

50

51

52 (azlactone)

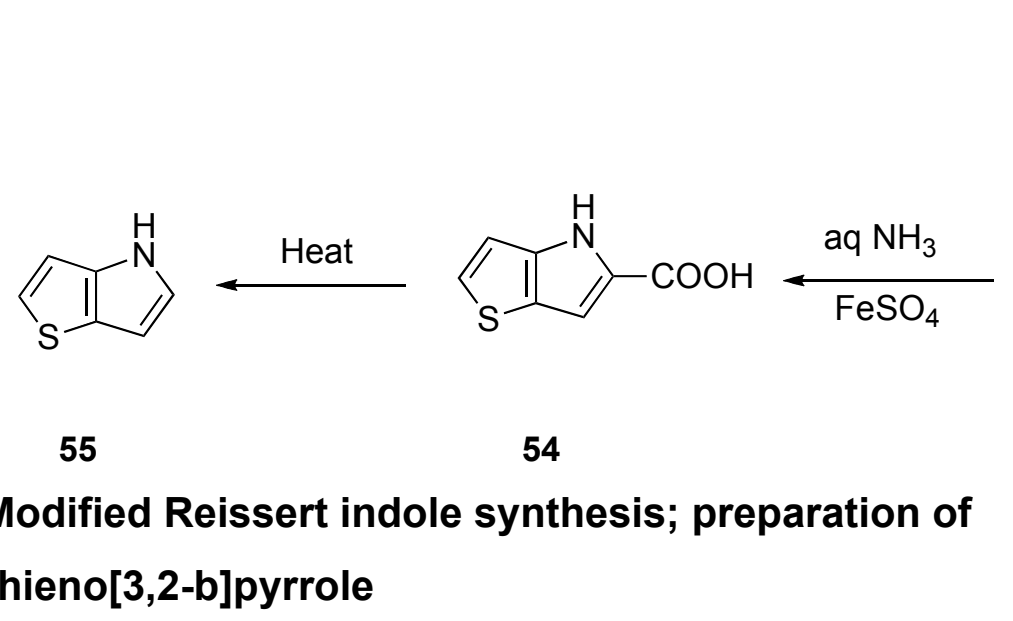

The "Reissert indole synthesis" sequence of preparing the pyruvic ester (56) from 2methyl-3-nitrotoluene (49) and diethyloxalate was utilized in the preparation of 5carboethoxy thieno[2,3-b]pyrrole (21a) (Scheme 12).<smiles>CCOC(=O)c1ccsc1[N+](=O)[O-]</smiles>

49<smiles>CCOC(=O)Cc1sccc1[N+](=O)[O-]</smiles>

56<smiles>CCOC(=O)c1cc2sccc2[nH]1</smiles>

21a

Scheme 12: 5-carboethoxy thieno[2,3-b]pyrrole via the Reissert indole synthesis

With the observed instability of the parent thienopyrroles, an alternate approach to synthesize the thieno[3,2-b]pyrrole (55) as well as the $\mathrm{N}$-benzyl derivative (55a) from pyrrole was designed by Snyder. ${ }^{33}$ This route features the unusual formation of 3- 
thiocyanopyrrole (58) from the pyrrole (57) and thiocyanogen. The 3-thiocyanopyrrole (58) was converted into the 3-pyrrolylthioacetic acid (59) which was cyclized to the thieno[3,2-b]pyrrole-3-one (60) in presence of polyphosphoric acid. Sodium borohydride reduction of 60 afforded the desired thieno[3,2-b]pyrrole (55) (Scheme 13).

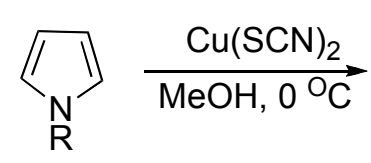

57

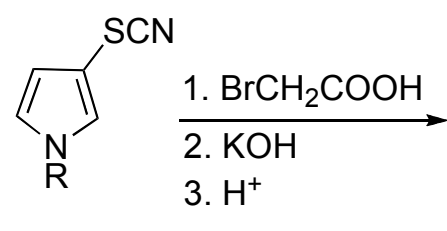

58

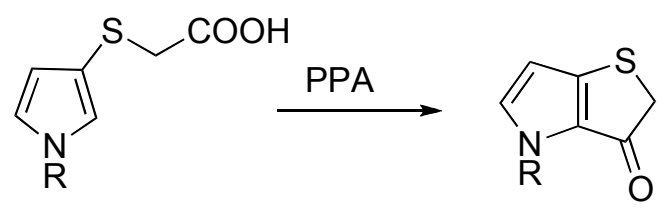

60

59

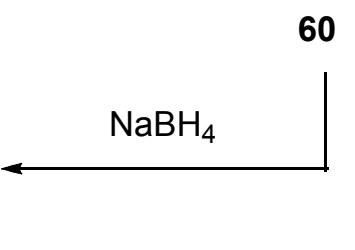

$55(\mathrm{R}=\mathrm{H})$

55a $(\mathrm{R}=\mathrm{Bn})$

\section{Scheme 13: The alternate syntheses of thieno[3,2-b]pyrroles via "thiocyanation" route.}

The isomeric $\mathrm{N}$-benzylthieno[2,3-b]pyrrole (67) was synthesized by a slightly different procedure $^{34}$ from N-benzyl-3,4-pyrroledicarboxylate (61). Compound 61 was converted into the intermediate 2-thiocyano pyrrole derivative (62) utilizing thiocyanogen chloride in the first step. This step was followed by the preparation of the pyrroylthioacetate (63) by sodium borohydride reduction and subsequent alkylation with ethylbromoacetate. The pyrroylthioacetate (63) cyclized to the thieno[2,3-b]pyrrole diester (64) through a $\mathrm{NaH}$ driven Diekmann condensation. Hydrolysis and decarboxylation in presence of sulphuric acid led to the keto acid (64), which was converted to the desired Nbenzylthieno[2,3-b]pyrrole (67) by subsequent reduction and decarboxylation (Scheme 14). 
<smiles>CCOC(=O)c1c[nH]cc1C(=O)OCC</smiles>

61

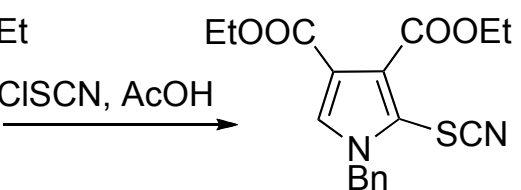

62<smiles>[R]OC(=O)COC(=O)COCC</smiles>

63

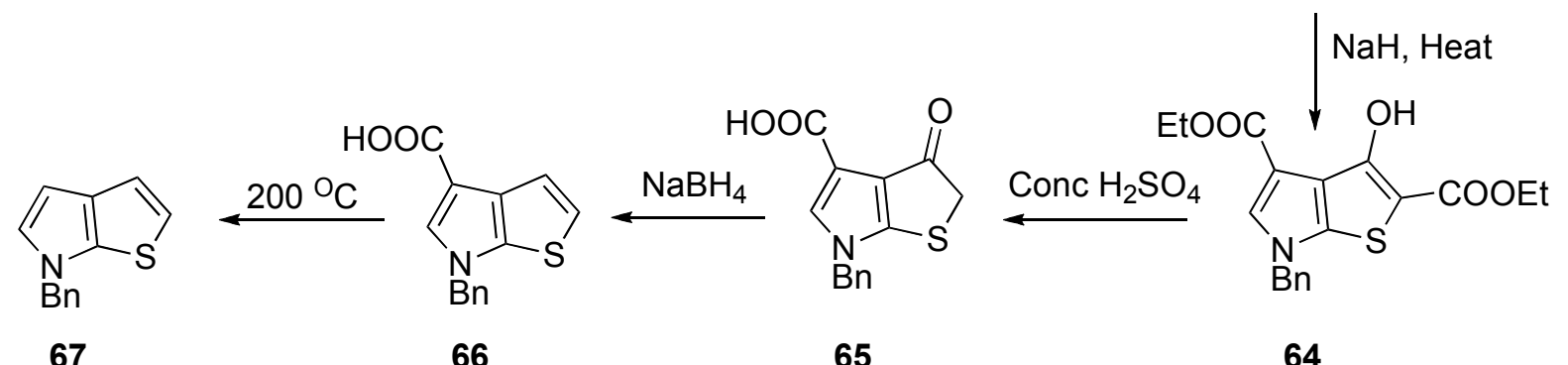

67

66

65

64

Scheme 14: Synthesis of $\mathrm{N}$-benzylthieno[2,3-b]pyrrole via thiocyanation

\section{2 (g) Synthesis from ketene-N,S-acetals:}

Active methylene compounds have become a significant resource in the construction of several complex molecules. This strategy has been used to construct a thieno[2,3b]pyrrole in two steps, using alkyl or arylisothiocyanate as shown in the Scheme 15.35 The first step in this synthesis involved a base catalyzed condensation of an activated methylene compound (68) with an alkyl or an aryl-isothiocyanate to form an intermediate ketene aminothioacetal (69), which reacts with a-bromoethylacetate to form the corresponding aminothioacetal (70). A Dieckman cyclization or a ThorpeZiegler cyclization of $\mathbf{7 0}$ affords the thiophene (71). The fusion of the pyrrole ring occured as the second step, with the reaction between the thiophene 71 and $\alpha-$ bromoethylacetate in the presence of anhydrous potassium carbonate. The thieno[2,3b]pyrrole (72) was obtained as the product after 5 days when acetone was chosen as the solvent. 
In a comparative study, the same compound was synthesized from the pyrrole derivative (74). The first step in this study involved the formation of N-phenyl-Smethylketene-N,S-acetal (73) from compound 68, phenylisothiocyanate and methyliodide under similar basic conditions. Subsequent transformation into the 2methylsulfanylpyrrole derivative (74) was easily achieved from a base mediated concurrent substitution condensation of 73 with $\alpha$-bromoethylacetate. The ultimate construction of the thiophene ring on the pyrrole $\mathbf{7 4}$ was brought forth by a nucleophillic aromatic substitution with thiogycolate in presence of a strong base. These two routes developed by the Kirsch group ${ }^{35}$ were used to synthesize a variety of thieno[2,3b]pyrroles. However, this reaction is limited to the synthesis of penta-substituted thieno[2,3-b]pyrroles only.

Route 1:

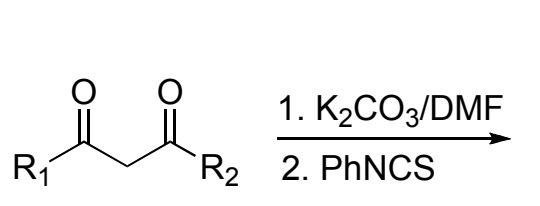

68

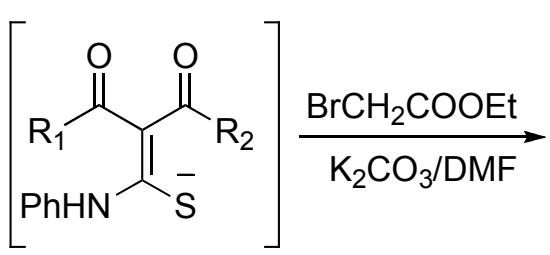

69<smiles>[R]C(=O)C(C([R])=O)=C(N)SCC(=O)OCC</smiles>

70<smiles>[R2]c1c(C(=O)OCC)[nH]c2sc(C(=O)OCC)c([R])c12</smiles>

72 (73\%)

$\mathrm{R}_{1}=\mathrm{R}_{2}=\mathrm{Me}$
$\frac{\mathrm{BrCH}_{2} \mathrm{COOEt}}{\mathrm{K}_{2} \mathrm{CO}_{3} \text {, Acetone }}$<smiles>[R]C(=O)c1c(Nc2ccccc2)sc(C(=O)OCC)c1[R2]</smiles>

71 (79\%) 
Route 2:<smiles>[R]C(=O)CC([Y10])[R]([H])([H])[H]</smiles>

68<smiles>[R]C(=O)C(C([R])=O)=C(Nc1ccccc1)SC</smiles>

73<smiles>[R]C(=O)c1c(C)[nH]c(-c2ccccc2)c1C(=O)OCC</smiles>

74<smiles>[R2]c1c(C(=O)OCC)[nH]c2sc(C(=O)OCC)c([R])c12</smiles>

72 (71\%)

$\mathrm{R}_{1}=\mathrm{R}_{2}=\mathrm{Me}$

\section{Scheme 15: Preparation of thieno[2,3-b]pyrroles from ketene-N-S-acetals}

\section{2 (h) Synthesis of a pyrrolo[3,2-d]thiazole derivative:}

A lately reported two step synthesis of a pyrrolo[3,2-d]thiazole ring system involved the preparation of an intermediate thiooxamide (76) from an aminopyrrole derivative (75) using sulphur and chloroacetamide. The oxidative cyclization of the intermediate thioxamide (76) with $\mathrm{K}_{3}\left[\mathrm{Fe}(\mathrm{CN})_{6}\right]$ under basic conditions gave the pyrrolo[3,2-d]thiazole derivative (77) as the product (Scheme 16). ${ }^{36}$

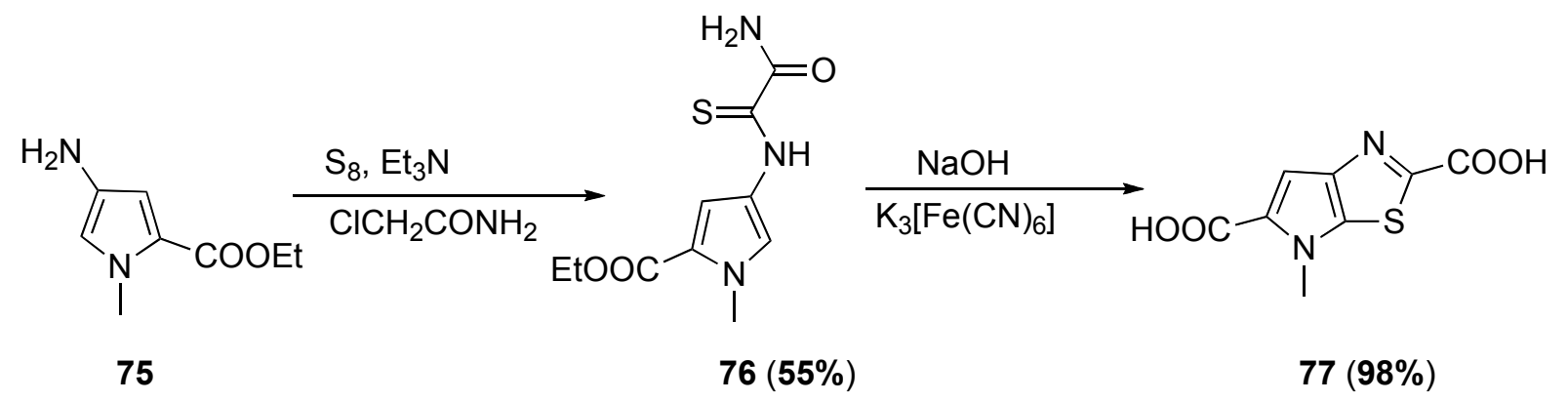

Scheme 16: Synthesis of the pyrrolo[3,2-d]thiazole derivative via oxidative cyclization 


\subsection{Transition metal mediated syntheses of pyrroloheterocycles}

\section{3 (a) Introduction:}

A glance at the Hemmetsberger-Knittel, Sundberg, and Cadogan-Sundberg syntheses depict the formation of nitrenes as intermediates. Current research has focussed on either generating or trapping these nitrenes with transition metals. Nickel, platinum, rhodium, ruthenium, molybdenium ${ }^{37}$ and tin have been used in these strategies. ${ }^{38} \mathrm{~A}$ number of fused nitrogen-heterocycles were synthesized in high yields by Driver and his group ${ }^{39}$ utilizing the concept of rhodium (II) mediated insertion of nitrene into a $\mathrm{C}-\mathrm{H}$ bond (Table 3). The highlight of this reaction was the tolerance of $5 \%$ rhodium perfluorobutyrate to both electron donating and withdrawing substituents on the aryl ring and the generation of the rhodium nitrenoid (79) at sufficiently low temperatures.

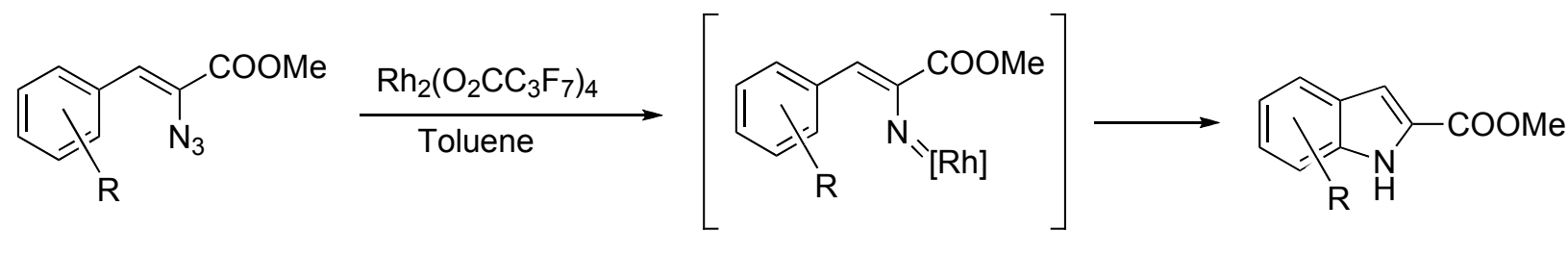

78

79

80

Scheme 17: Rhodium (II) catalyzed synthesis of nitrogen heterocycles 
Table 3: Examples of the $\mathrm{N}$-heterocyclic compounds synthesized with $5 \% \mathrm{Rh}$ (II) at $60^{\circ} \mathrm{C}$

Entry Substrate

The ability to form stable complexes with ligands has rendered palladium as an ideal catalyst in a number of bond formation reactions in organic chemistry. An application of the palladium-catalyzed intramolecular Heck reaction has been described by Wensbo and Gronowitz to synthesize all the three isomeric thienopyrrole derivatives from the respective Boc-protected aminohalo-thiophenes (Table 4)..$^{40}$ 
Table 4: Intramolecular Heck reaction in the synthesis of the three isomeric thienopyrroles

Entry Substrate

Catalyst: $\mathrm{Pd}(\mathrm{OAc})_{2}, \mathrm{PPh}_{3}, \mathrm{~K}_{2} \mathrm{CO}_{3}$

\section{3 (b) Palladium-catalyzed reductive N-heteroannulation:}

Among the multitude of palladium-catalyzed reactions that have been and are still being used by a number of researchers around the world, a class of reactions known as "palladium-catalyzed reductive $\mathrm{N}$-heteroannulation" reactions has created a niche for itself in the realm of palladium chemistry. Cenini et. al reported the first palladium catalyzed de-oxygenation of o-substituted nitrostyrenes in the presence of carbon monoxide under high temperatures and high pressures. ${ }^{41}$ An example from their study on (2-pyridyl)-o-nitrostyrene (81) with $5 \mathrm{~mol} \% \mathrm{Pd}(\mathrm{TMB})$ under $40 \mathrm{~atm}$. of $\mathrm{CO}$ at $180^{\circ} \mathrm{C}$ for 3 hours gave 2-pyridylindole (82) in good yield (Scheme 18). ${ }^{41}$ 


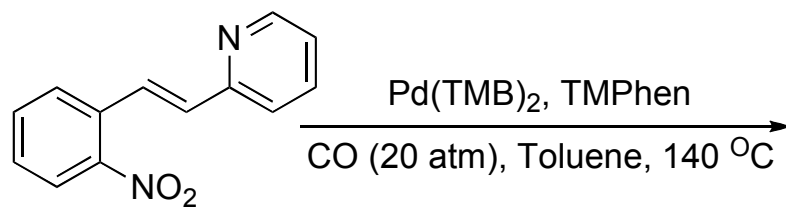

81<smiles>c1ccc(-c2cc3ccccc3[nH]2)nc1</smiles>

82 (97\%)

Scheme 18: The palladium-catalyzed reductive de-oxygenation reaction by the "Cenini group"

With the product, an indole, being the same as the one obtained from the conventional Cadogan-Sundberg reaction, Cenini proposed that this reaction also goes through a nitrene intermediate, likely bound to the metal (Figure 7). ${ }^{42}$ Evidence for this proposition was later established by Cenini when a ruthenium carbonyl-bound nitrene (84) was isolated from a reaction between 2-nitrobiphenyl (83) and a stoichiometric amount of $\mathrm{Ru}_{3}(\mathrm{CO})_{12}$. This intermediate metal-bound nitrene reacted with carbon monoxide to yield the carbazole (85) (Scheme 19). ${ }^{43}$

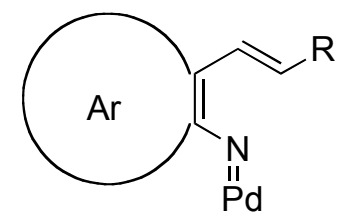

Figure 7: The hypothetical palladium-bound nitrene intermediate<smiles>O=[N+]([O-])c1ccccc1-c1ccccc1</smiles>

83

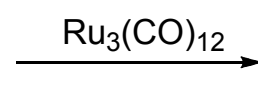<smiles>[R20]C(=O)Nc1ccccc1-c1ccccc1</smiles>

84

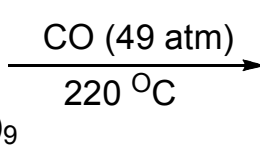<smiles>c1ccc2c(c1)[nH]c1ccccc12</smiles>

85

Scheme 19: Reduction of the ruthenium-bound nitrene 
Watanabe and his co-workers reported a similar palladium catalyzed reductive $\mathrm{N}$ heteroannulation of nitroarenes to form indoles. The formation of indole-2-carboxylate (87) from the nitroarene (86) under the catalytic conditions of bis-triphenylphosphine palladium(II)chloride and stannous chloride is shown under Scheme $20 .{ }^{44}$ Although the reaction conditions were milder than Cenini's protocol, yields of indoles were moderate.

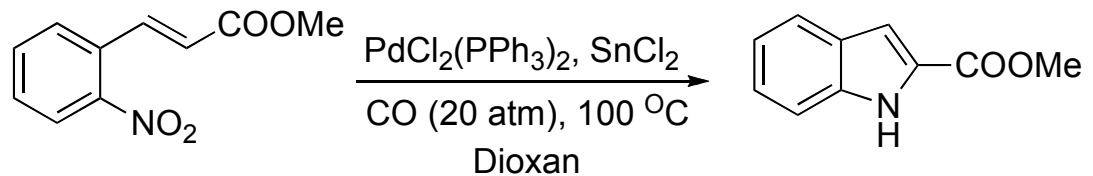

86

$87(62 \%)$

\section{Scheme 20: Watanabe conditions- the palladium- $\mathrm{SnCl}_{2}$ catalyzed formation of indoles}

Much milder conditions for the reductive heteroannulation were discovered in our laboratory a decade ago ${ }^{45}$ The reaction behind this discovery was the formation of 4bromoindole (89) from 1-(2-bromo-6-nitrophenyl)-ethene (88) (Scheme 21). Since then, this methodology has been thoroughly investigated on a wide range of substrates. ${ }^{46}$ This reaction is performed with $6-10 \mathrm{~mol} \%$ palladium catalyst, a ligand, and carbon monoxide (4-6 atm) pressure in a suitable solvent. It was also observed that the reductive $\mathrm{N}$-heteroannulation of a mixture of $(\mathrm{E} / \mathrm{Z})$ isomers of $\mathbf{9 0}$ gave the indole $\mathbf{9 1}$ indicating that the stereochemistry at the double bond in the o-nitrostyrene does not effect the yield or the rate of the reaction (Scheme 22) ${ }^{46}$

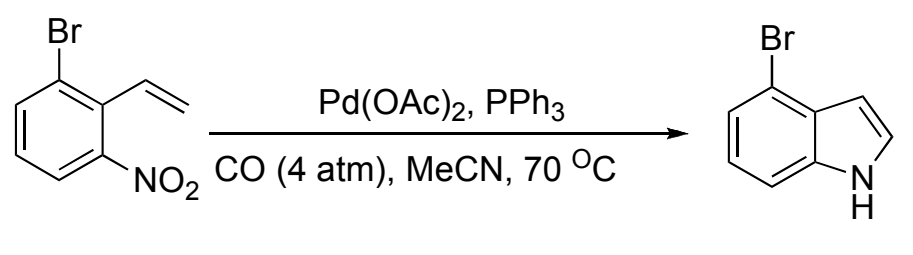

\section{Scheme 21: The conditions for reductve $\mathrm{N}$-heteroannulation}




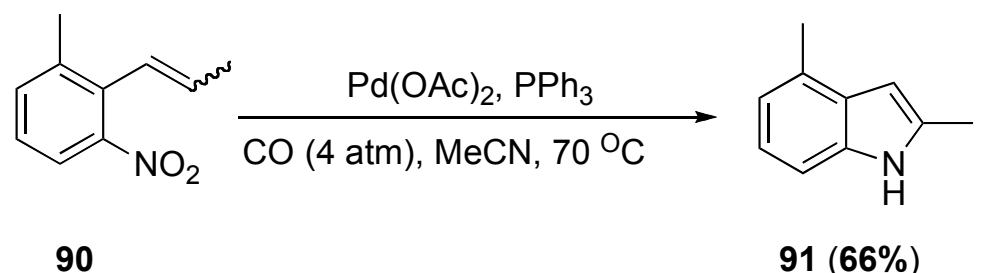

Scheme 22: The reductve $\mathrm{N}$-heteroannulation of the isomeric mixture

\section{3 (c) Proposed Mechanism:}

A plausible mechanism for the $\mathrm{N}$-heteroannulation would involve the coordination of palladium to the nitro group of the o-nitrostyrene 92 to form a palladocycle $\mathbf{9 3}$ in the first step. Carbon monoxide insertion would form 94 , which would form the intermediate palladium bound o-nitrosostyrene 95 after the loss of carbon dioxide. One of the pathways suggested from this intermediate, proceeds through a reductive elimination of $\mathrm{Pd}(0)$ to give a free nitroso styrene $95 \mathrm{a}$. An intramolecular cyclization followed by a $[1,5]-\mathrm{H}$ shift would lead to an $\mathrm{N}$-hydroxy indole $\mathbf{9 5 d}$, which would ultimately be reduced to the indole (96).

The second suggested pathway from 95 parallels the idea of metal bound nitrenes. The insertion of carbon monoxide to form 95e, and subsequent loss of carbon dioxide would form the palladium bound nitrene (95f). Cyclization, reductive elimination and $[1,5] \mathrm{H}$ shift would sequentially lead to the indole (96). Another feasible pathway through the loss of $\mathrm{Pd}(0)$ to form a free nitrene $\mathbf{9 5 i}$ from the palladium bound nitrene (95f) is also suggested. An electron cyclization of the free nitrene to the intermediate $95 \mathbf{j}$ followed by a $[1,5]-\mathrm{H}$ shift would form the indole 96 (Scheme 23). 


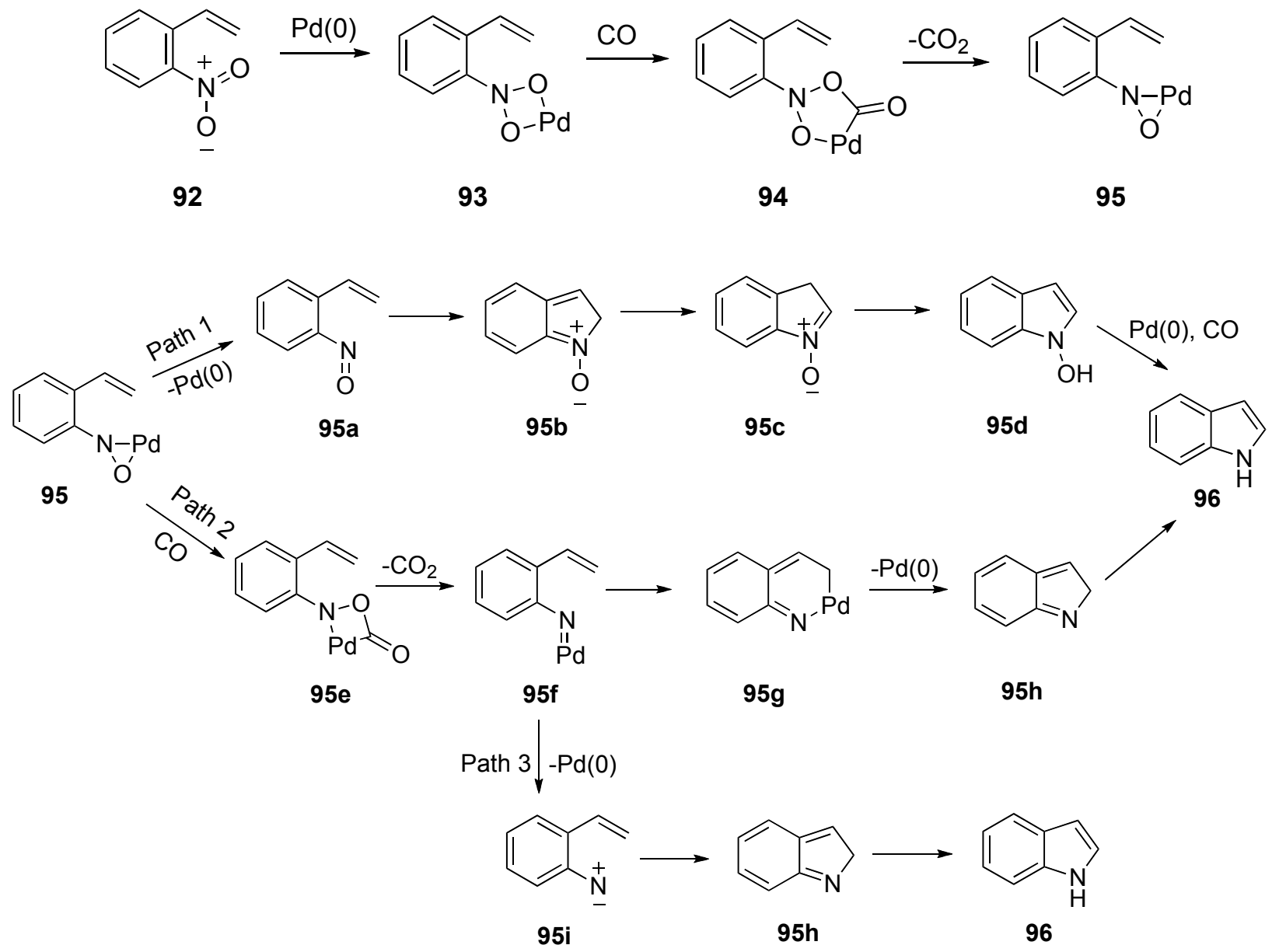

Scheme 23: Plausible mechanistic pathways for the $\mathrm{N}$-heteroannulation reaction

\subsection{Results and discussion:}

The "reductive N-heteroannulation", developed in our laboratories, has been successful in the synthesis of substituted and fused indoles, carbazoles, benzimidazoles, azaindoles, ${ }^{47}$ diazaindoles, carbazolones, and several natural products. ${ }^{46}$ From this perspective, the synthesis of fused bicyclic pyrroloheterocycles (100) from their respective alkenyl nitroarenes (99) was visualised. These precursor alkenyl nitroarenes could be prepared via Kosugi-Migita-Stille ${ }^{48}$ couplings of halo- 
nitroarenes (97) or by condensations of methyl-nitroarenes (98) with benzaldehyde as depicted in Scheme 24.

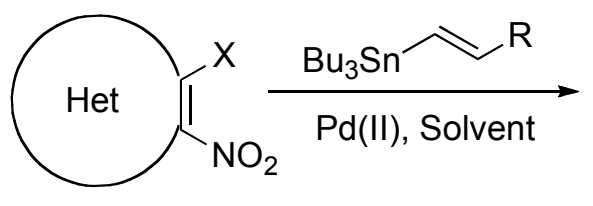

$\mathrm{X}=\mathrm{Cl}, \mathrm{Br}$, OTf

97

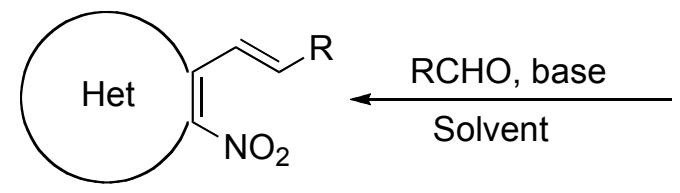

99

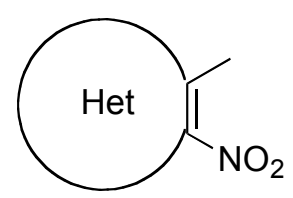

98

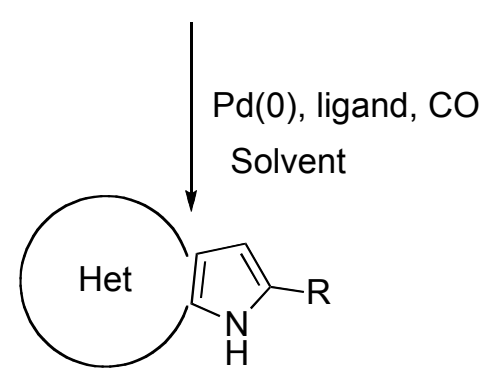

$\mathrm{R}=\mathrm{H}, \mathrm{Ph}$

100

\section{Scheme 24: The general strategy to synthesize the fused pyrroloheterocycles}

An account of the synthesis and attempted syntheses of some of the pyrroloheterocycles which belong to the $(5,5)$ fused category is presented henceforth.

\section{4 (a) Synthesis of thieno[3,2-b]pyrrole and thieno[2,3-b]pyrrole derivatives:}

The compounds chosen to test the applicability of the palladium-catalyzed $\mathrm{N}$ heteroannulation reaction in this category were the previously reported thieno[3,2b]pyrrole-5-carboxylic acid methyl ester (107) and 5-phenylthieno[2,3-b]pyrrole (109).49 The synthesis of the thieno[3,2-b]pyrrole derivative began with the nitration of the 2methyl-5-thienic acid (101). ${ }^{49}$ Esterification of the nitro derivative 102 afforded 5- 
methyl-4-nitrothiophene-2-carboxylic acid methyl ester $(\mathbf{1 0 3})^{49}$, which underwent a base catalyzed condensation with benzaldehyde to yield the precursor styrylthiophene $104 .{ }^{49}$

2-Nitrothiophene (105) was the compound of choice to synthesize the thieno[2,3b]pyrrole analogue. Conjugate addition ${ }^{50}$ of methyl magnesium chloride to $2-$ nitrothiophene gave an inseparable mixture of the three possible isomeric methylnitrothiophenes (106). Nitration of 3-methylthiophene was also attempted using Rinke's method, ${ }^{51}$ but a low yield of 3-methyl-2-nitrothiophene gave us no alternative other than to proceed with the mixture of the three isomers. Base catalyzed condensation with benzaldehyde yielded 2-nitro-3-styrylthiophene (107 $)^{49}$ along with some unidentified material illustrating the necessity of an adjacent electron withdrawing group on the arene to activate the methyl group for condensation (Scheme 25).

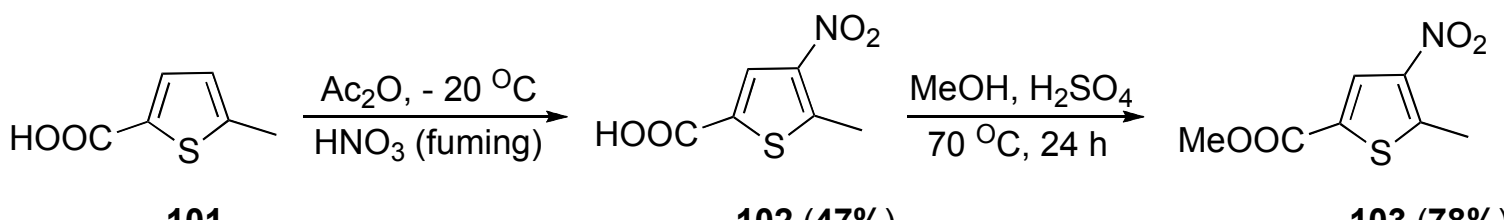

101 $102(47 \%)$ $103(78 \%)$
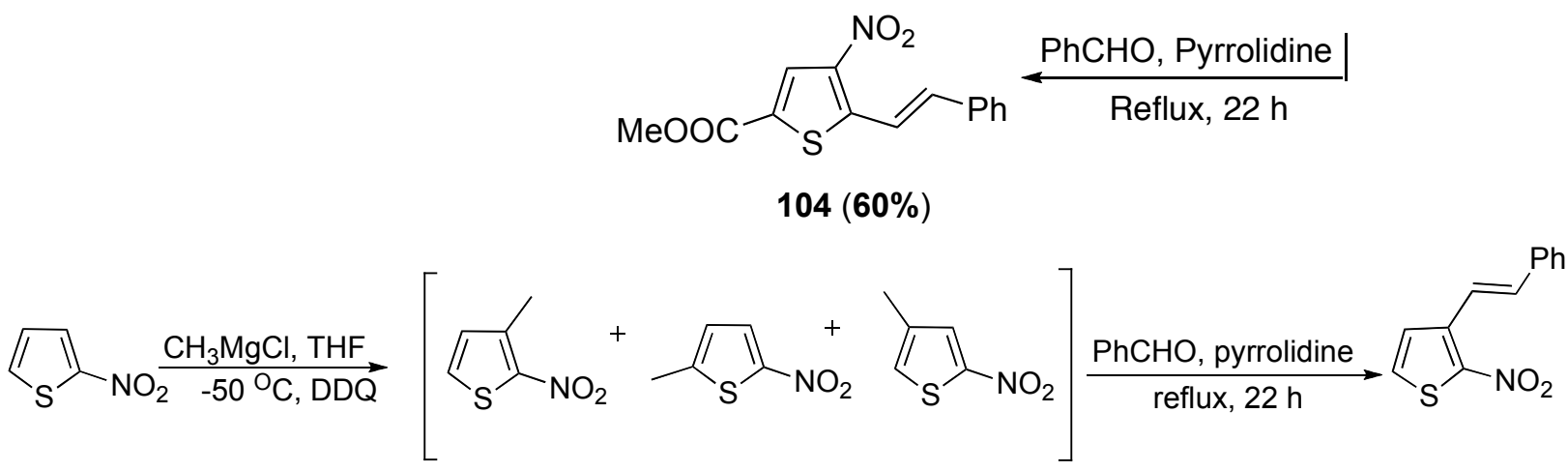
Heteroannulation of the two styrylthiophenes 104 and 107 with carbon monoxide under the catalytic conditions of palladium diacetate and triphenyl phosphine afforded the respective thienopyrroles 108 and 109 in good yields (Table 5).

Table 5: Heteroannulation of the styrylthiophenes, 104 and 107

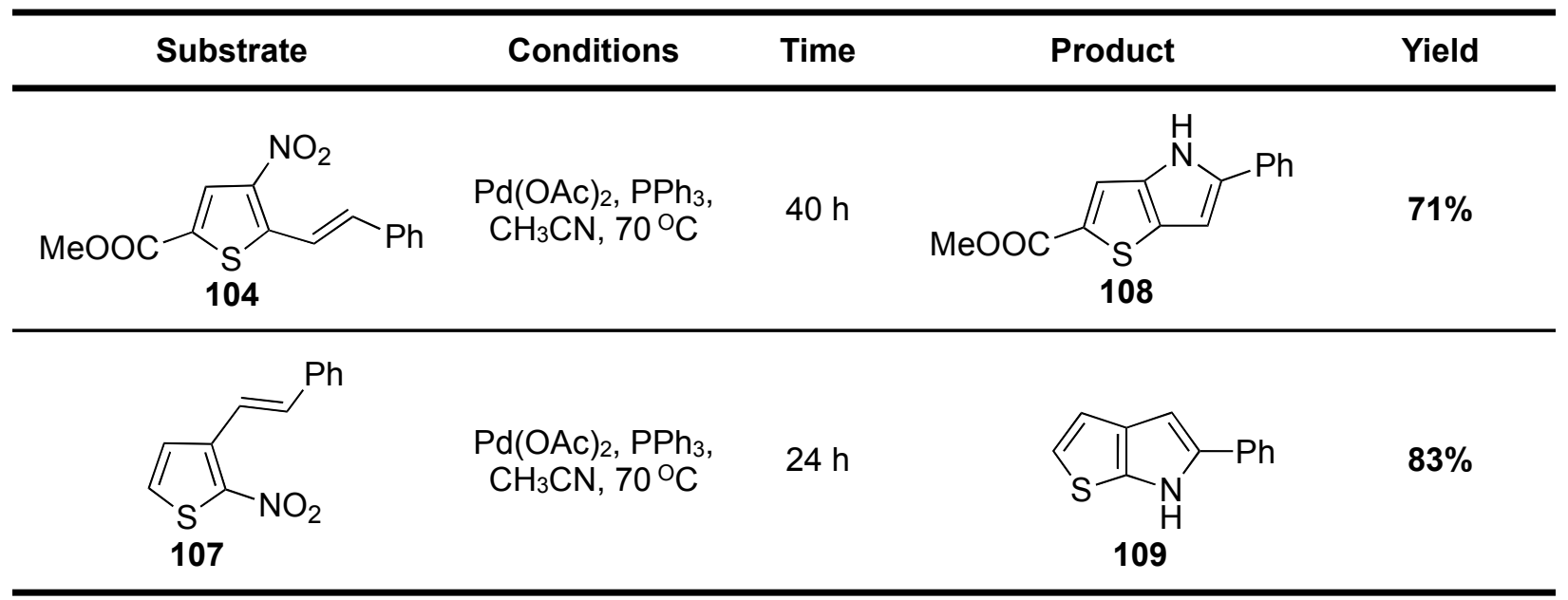

The commercial availability of 2,5-thioxene (110) contributed to the task of executing the synthesis of a thieno[3,2-b:4,5-b']dipyrrole derivative (114). 2,5-Dimethyl-3,4dinitrothiophene (111) was synthesized from 2,5-dimethylthiophene (110) utilizing the procedure reported by Steinkoff et.al. ${ }^{52} \mathrm{~A}$ base catalyzed condensation with benzaldehyde gave the precursor 3,4-dinitro,2-5-distyrylthiophene (112) as bright orange crystals (Scheme 26$) \cdot{ }^{53}$

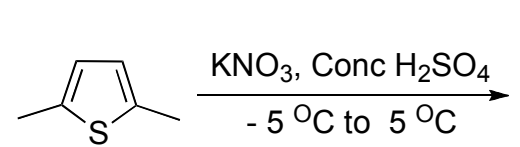

110<smiles>Cc1sc(C)c([N+](=O)[O-])c1[N+](=O)[O-]</smiles>$$
\underline{P}
$$

$$
111(12 \%)
$$

PhCHO, piperidine, isopropanol $8 \mathrm{~h}, 80^{\circ} \mathrm{C}$<smiles>O=[N+]([O-])c1c(/C=C/c2ccccc2)sc(/C=C/c2ccccc2)c1[N+](=O)[O-]</smiles>

$112(67 \%)$

Scheme 26: Synthesis of 3,4-dinitro-2,5-distyrylthiophene (112) 
When subjected to heteroannulation conditions with $6 \% \mathrm{Pd}(\mathrm{OAc})_{2}$, this compound (112) afforded only a trace amount of the dipyrrole 114 and 2-styryl-3-nitro-5-phenyl-4Hthieno[3,2-b]pyrrole $(\mathbf{1 1 3})^{53}$. Increasing the catalyst load to $11 \%$ gave the dipyrrole exclusively, but in a moderate yield. The cyclization studies on the compounds 112 and 113 under different amounts of catalyst are presented in Table 6.

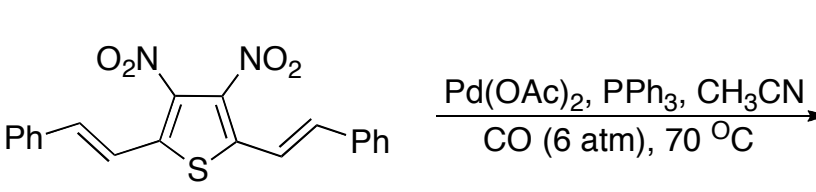

112<smiles>O=[N+]([O-])c1c(/C=C/[PH+]c2ccccc2)sc2cc(-c3ccccc3)[nH]c12</smiles>

113<smiles>c1ccc(-c2cc3sc4cc(-c5ccccc5)[nH]c4c3[nH]2)cc1</smiles>

114

Scheme 27: The heteroannulation of 3,4-dinitro,2-5-distyrylthiophene (112)

Table 6: Conditions evaluated in affecting the cyclization of 3,4-dinitro,2-5-distyrylthiophene (112)

\begin{tabular}{lcclll}
\hline Entry & Substrate & Catalyst loading & Time & $0 \%$ & $37 \%$ \\
\hline 1 & 112 & $11 \% \mathrm{Pd}(\mathrm{OAc})_{2}$ & 4 days & $89 \%$ & Trace \\
2 & 112 & $6 \% \mathrm{Pd}(\mathrm{OAc})_{2}$ & $60 \mathrm{~h}$ & $0 \%$ & $35 \%$ \\
3 & 112 & $30 \% \mathrm{Pd}(\mathrm{OAc})_{2}$ & 4 days & $89 \%$ & Trace \\
4 & 113 & $6 \% \mathrm{Pd}(\mathrm{OAc})_{2}$ & 2 days & $31 \%$ & $15 \%$ \\
\hline
\end{tabular}

The above results, wherein the formation of $\mathbf{1 1 4}$ occurred in trace quantities from 112 and 113 (Entry $2 \& 4$, Table 6 ) as well as in a moderate yield (Entry $1 \& 3$, Table 6 ) imply that the aforementioned bicyclisation occurs as a discrete step, which requires a greater amount of catalyst loading. 


\section{4 (b) Synthesis of furo[3,2-b]pyrrole derivatives:}

With the requirement of a halo or an alkyl substituent adjacent to the carbon bearing the nitro group, the procurement of an ideal precursor for the synthesis of furan analogues was an arduous task. An article by Saldabol et al. ${ }^{54}$ in which the procedure for the nitration of 5-methyl-2-furanaldoxime $(115)^{55}$ was reported, assisted us to obtain the required precursor (Scheme 28). 5-Methyl-4-nitro-2-furanaldoxime (117), thus prepared, underwent the base catalyzed condensation with benzaldehyde to afford the precursor 4-nitro-5-styryl-2-furanaldoxime (118). Reductive heteroannulation with bis(dibenzylideneacetone) palladium $\left(\operatorname{Pd}(\mathrm{dba})_{2}\right)$ and 1,10-phenanthroline gave a mixture of the corresponding furo[2,3-b]pyrrole as the oxime (119) and nitrile (120) (Table 7). Extension of the reaction time led to a decrease in the amount of the oxime, which indicated that the oxime gradually dehydrated to the corresponding nitrile (120). This result was comparable to the observed decomposition of the isolated oxime at room temperature. On the other hand, heteroannulation conditions with $\operatorname{Pd}(\mathrm{OAc})_{2}$ and $\mathrm{PPh}_{3}$ resulted in trace quantities of the nitrile and some unidentified matter.

A test reaction performed on 5-methyl-2-furanaldoxime (115) with $\mathrm{Pd}(\mathrm{dba})_{2}$ did not yield any nitrile. This confirmed the necessity of a fused pyrrole moiety to facilitate the dehydration process (Scheme 29). 


$$
\text { (25\%) }
$$

Scheme 28: Preparation of 4-nitro-5-styryl-2-furanaldoxime (118)

Table 7: Heteroannulation conditions evaluated on 4-nitro-5-styryl-2-furanaldoxime (118)

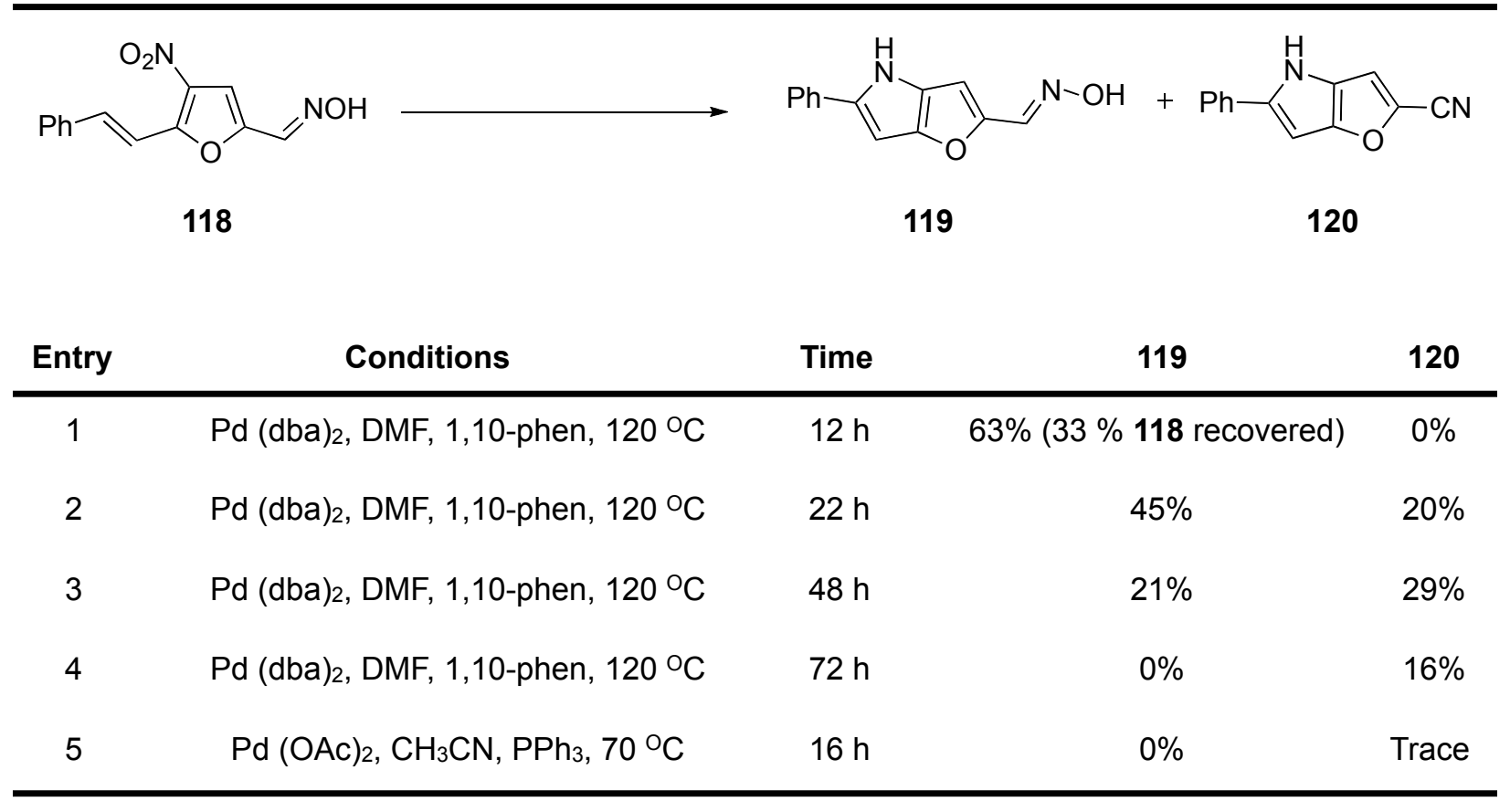

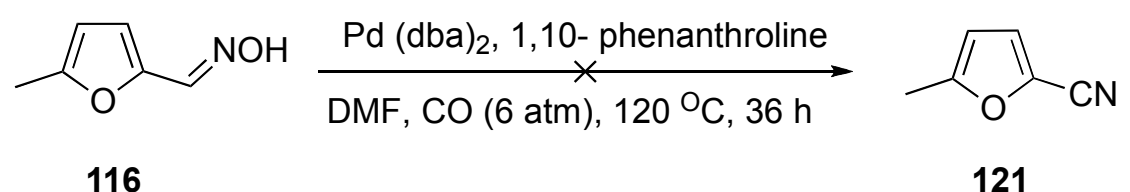

Scheme 29: The test reaction on 5-methyl-2-furanaldoxime (116) 


\section{4 (c) Synthesis of 2-methyl-5-phenyl-4H-pyrrolo[3,2-d]thiazole:}

The reaction between an $\alpha$-haloketone and thioamide to form a thiazole has been known for more than a century. Widely recognized as the "Hantz thiazole synthesis" 56 , this reaction has become one of the favorite "thiazole" syntheses owing to the ease of transformation of the reactants into the desired product. Low cost of these reactants is an added advantage. The synthesis of the pyrrolo[3,2-d]derivative (127), began with the utilization of Hantz synthesis to prepare 2,4-dimethylthiazole (124) from a-chloroacetone (123) and thioacetamide (122) following literature procedure. ${ }^{57}$ The sequential nitration ${ }^{58}$ and condensation, ${ }^{59}$ followed by annulation, gave the desired pyrrolo[3,2-d]thiazole derivative (127) (Scheme 30). The results of heteroannulation under different catalytic conditions are presented in Table 8.

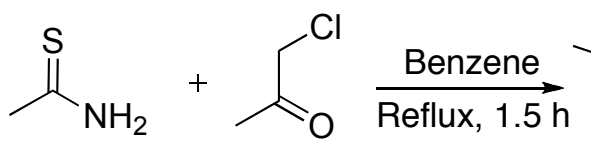

122
123

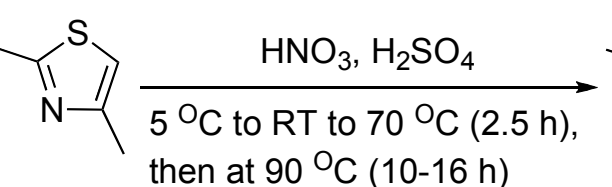

$124(65 \%)$<smiles>Cc1nc(C)c([N+](=O)[O-])s1</smiles>

$125(69 \%)$

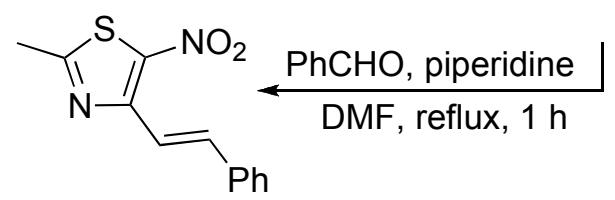

$126(10 \%)$

Scheme 30: Preparation of 2-methyl-4-nitro-5-styrylthiazole (126) 
Table 8: Heteroannulation of the styrylthiazole (126) under different catalytic conditions

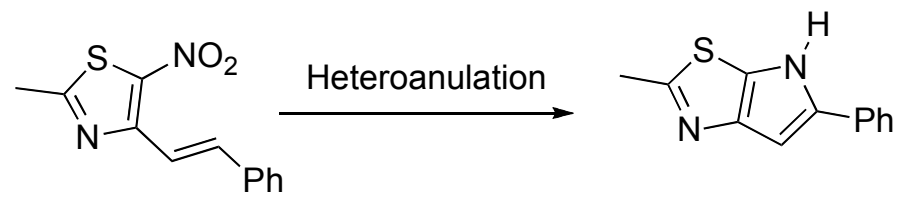

126

127

\begin{tabular}{cccc} 
Entry & Conditions & Time & $\mathbf{1 2 7}$ \\
\hline 1 & $\mathrm{Pd}(\mathrm{dba})_{2}, \mathrm{DMF}, 1,10-\mathrm{phen}, 120^{\circ} \mathrm{C}$ & 3 days & $16 \%$ \\
\hline 2 & $\mathrm{Pd}(\mathrm{OAC})_{2}, \mathrm{CH}_{3} \mathrm{CN}, \mathrm{PPh}_{3}, 80^{\circ} \mathrm{C}$ & 3 days & $\mathbf{6 1 \%}$ \\
\hline 3 & $\mathrm{PdCl}_{2}, \mathrm{CH}_{3} \mathrm{CN}, \mathrm{PPh}_{3}, 80^{\circ} \mathrm{C}$ & 3 days & $6 \%$ \\
\hline
\end{tabular}

\section{4 (d): Syntheses of pyrrolo[3,2-d]imidazole and pyrrolo[2,3-d]imidazole} derivatives:

According to our general methodology outlined under Scheme 21, it was obvious that both the designated pyrroloimidazole derivatives 133 and 134, could be synthesized from 4(5)-nitro-5(4)styrylimidazole (130). ${ }^{60}$ The latter compound was easily formed from the condensation of benzaldehyde with 4(5)-methyl-5(4)nitroimidazole (130). ${ }^{61}$ Facile benzylation of $\mathbf{1 3 0}$ with benzyl bromide in $\mathrm{N}, \mathrm{N}$-dimethylformamide-potassium carbonate afforded an easily separable mixture of the two isomeric precursors 131 and 132 in a ratio of $3: 1$, with an overall yield of $>85 \%$ (Scheme 31$) .60$ 

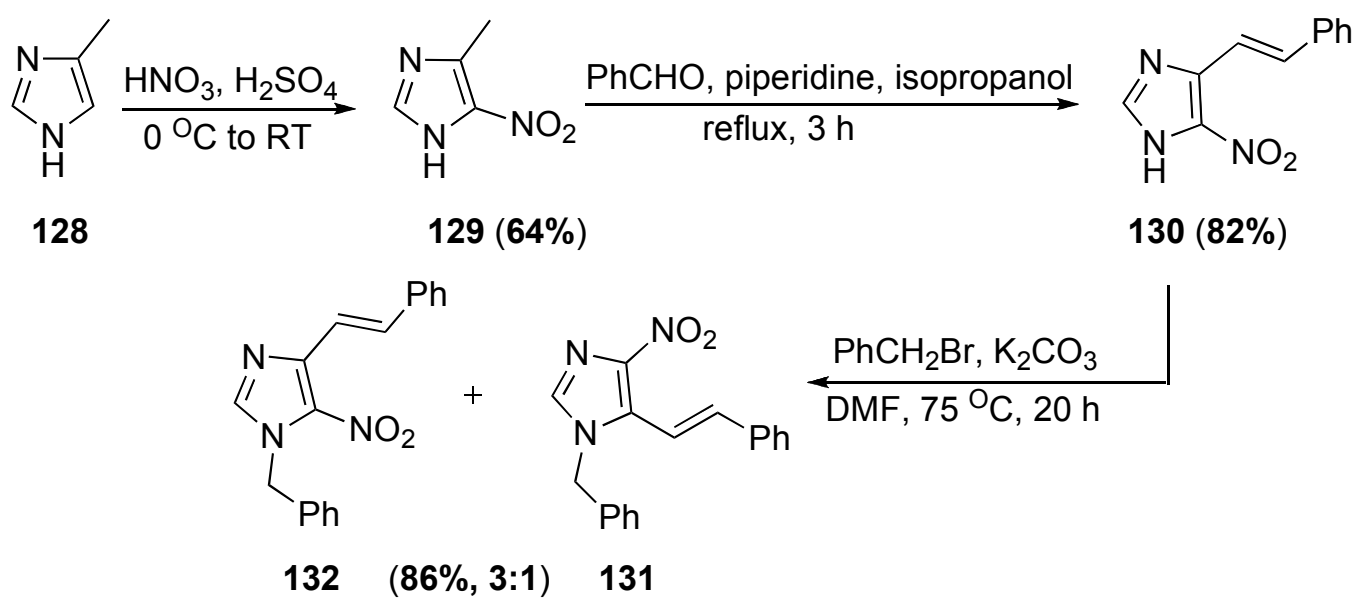

Scheme 31: Preparation of the two isomeric styrylimidazoles 131 and 132

Subsequent reductive N-heteroannulation of 131 and 132 in DMF with $\operatorname{Pd}(\mathrm{dba})_{2}$ and 1 , 10-phenanthroline afforded the desired pyrroloimidazoles 133 and 134, respectively.

Table 9: Preparation of the two isomeric pyrroloimidazoles 133 and 134

Conditions
$\begin{gathered}\text { Substrate } \\ \begin{array}{c}\mathrm{Pd}(\mathrm{dba})_{2}, \mathrm{DMF}, \\ 120^{\circ} \mathrm{C}\end{array}\end{gathered}$




\section{4 (e) Attempted synthesis of pyrrolo[2,3-d]isoxazole:}

With only one reported ${ }^{62}$ synthesis of 3-methyl-5-arylpyrrolo[2,3-d]isoxazole (137) to date, the approach via the "palladium-catalyzed heteroannulation" seemed ideal for a second synthetic account. Nitration of 3,5-dimethylisoxazole (135) afforded the 4-

nitro-3,5-dimethylisoxazole $(\mathbf{1 3 6})^{63}$, which condensed with benzaldehyde in presence of piperidine to give the precursor 3-methyl-4-nitro-5-styrylisoxazole (137) (Scheme 32). ${ }^{64}$

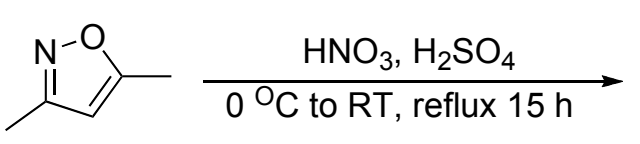

135<smiles>Cc1noc(C)c1[N+](=O)[O-]</smiles>

$136(44 \%)$
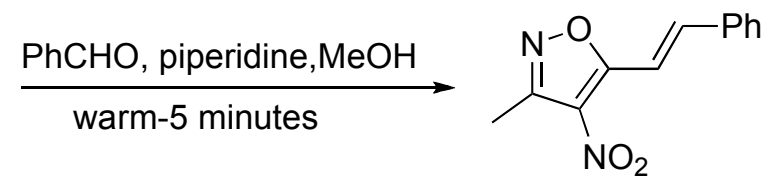

$137(28 \%)$

Scheme 32: Synthesis of 3-methyl-4-nitro-5-styrylisoxazole (137)

However, this precursor failed to yield the expected product (138) under the attempted heteroannulaton conditions (Table 10).

Table 10: Attempted heteroannulation of 3-methyl-4-nitro-5-styrylisoxazole (137)

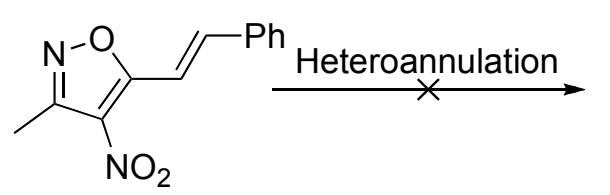

137<smiles>Cc1noc2cc(-c3ccccc3)[nH]c12</smiles>

138

\begin{tabular}{ccc} 
Entry & Conditions & Time \\
\hline $\mathbf{1}^{\mathbf{a}}$ & $\mathrm{Pd}(\mathrm{dba})_{2}, \mathrm{DMF}, 1,10$-phen, $\mathrm{CO}(6 \mathrm{~atm}), 120{ }^{\circ} \mathrm{C}$ & 4 days \\
\hline $\mathbf{2}^{\mathbf{a}}$ & $\mathrm{Pd}(\mathrm{OAc})_{2}, \mathrm{CH}_{3} \mathrm{CN}, \mathrm{PPh}_{3}, \mathrm{CO}(6 \mathrm{~atm}), 80^{\circ} \mathrm{C}$ & 3 days \\
\hline
\end{tabular}

a Starting material recovered 


\section{4 (f) Attempted syntheses of pyrrolopyrrole derivatives:}

Having met with substantial success so far in effecting cyclization of alkenyl nitroarenes to the expected fused $(5,5)$ pyrroloheterocycles, utilizing the heteroannulation conditions developed in our laboratory, the next target was the fused pyrrolopyrrole system. The first compound chosen in this category was a pyrrolo[3,2b]pyrrole (1e). The synthesis of compound 1e commenced with the nitration of $1,2,5-$ trimethylpyrrole (139) following the literature procedure reported by Pavia. ${ }^{65}$ By the manipulation of the reaction conditions, a trace of the 1,2,5-trimethyl-3,4-dinitropyrrole (141) along with the mononitropyrrole (140) was obtained (Scheme 33). Attempts to procure the requisite heteroannulation precursor 142 were futile, as no expected condensation reaction occurred between the mononitropyrrole and benzaldehyde (Table 11).

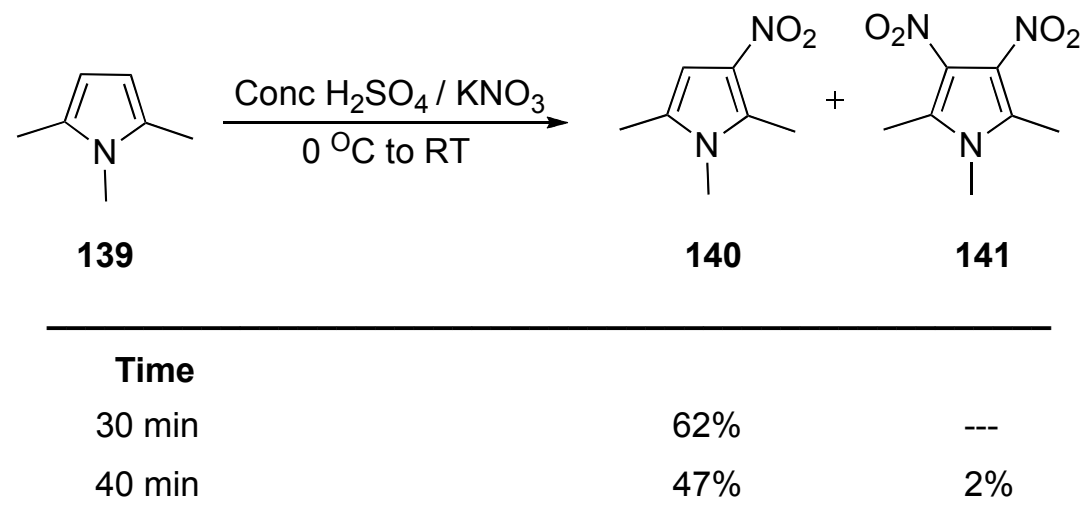

Scheme 33: Nitration of 1,2,5-trimethylpyrrole (139) 
Table 11: Conditions evaluated in the synthesis of the precursor styrylpyrrole 142

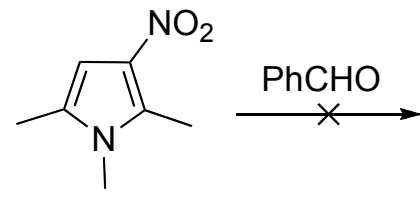

140

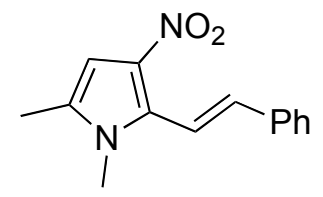

142

\begin{tabular}{ccccccc} 
Entry & PhCHO (eq) & Base(eq) & Solvent & Additive & Temp & Time \\
\hline 1 & 2.6 & $\mathrm{KOH}(3.3)$ & DMSO & -- & RT & $4 \mathrm{~h}$ \\
\hline 2 & 2.4 & $\mathrm{KOH}(3.3)$ & DMSO & -- & $\mathrm{RT}$ & $36 \mathrm{~h}$ \\
\hline 3 & 2.2 & $\mathrm{KOH}(2.2)$ & $\mathrm{DMSO}$ & -- & $\mathrm{RT}$ & $2 \mathrm{~h}$ \\
\hline 4 & 2.1 & piperidine & EtOH & --- & $60^{\circ} \mathrm{C}$ & $36 \mathrm{~h}$ \\
\hline 5 & 1.8 & piperidine & Benzene & --- & $80^{\circ} \mathrm{C}$ & $9 \mathrm{~h}$ \\
\hline 6 & 2.3 & piperidine & Benzene & AcOH & $80^{\circ} \mathrm{C}$ & $9 \mathrm{~h}$ \\
\hline 7 & 2.2 & $\mathrm{KOH}(2.2)$ & $\mathrm{CH}_{3} \mathrm{CN}$ & --- & $80^{\circ} \mathrm{C}$ & $8 \mathrm{~h}$ \\
\hline
\end{tabular}

After several unsuccessful attempts to condense $\mathbf{1 4 0}$ with benzaldehyde, it was decided to try the reaction on a pyrrole with an electron withdrawing substituent. The substrate by choice was 5-methyl-1-(4-chlorophenyl)pyrrole-2-carboxylic acid methyl ester (146), which was synthesized ${ }^{66}$ with ease from $p$-chloronitrosobenzene (144) and methylsorbate (143) in excellent yield. Nitration of 146 afforded the corresponding nitro derivative 147. But, even the presence of the electron withdrawing group on the pyrrole failed to give the desired condensation product 150. Even the 1-(4-chlorophenyl)-2methyl-3-nitropyrrole (149), obtained from the decarboxymethylation of 147 (Scheme 34) failed, to respond to the attempted condensations (Table 12 and 13). 

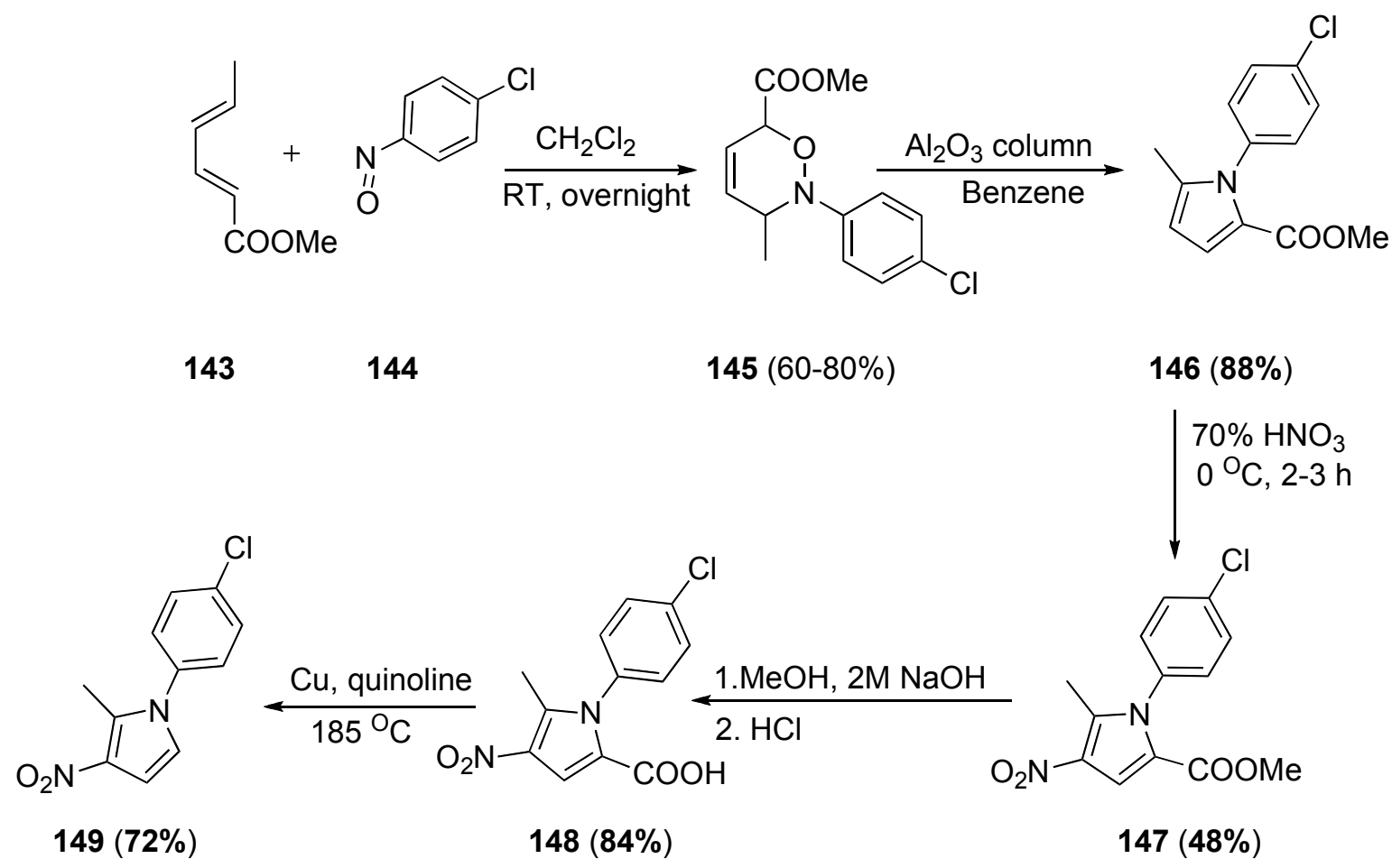

Scheme 34: Synthesis of 1-(4-chlorophenyl)-2-methyl-3-nitropyrrole (149) 
Table 12: Attempted condensation of (147) with benzaldehyde

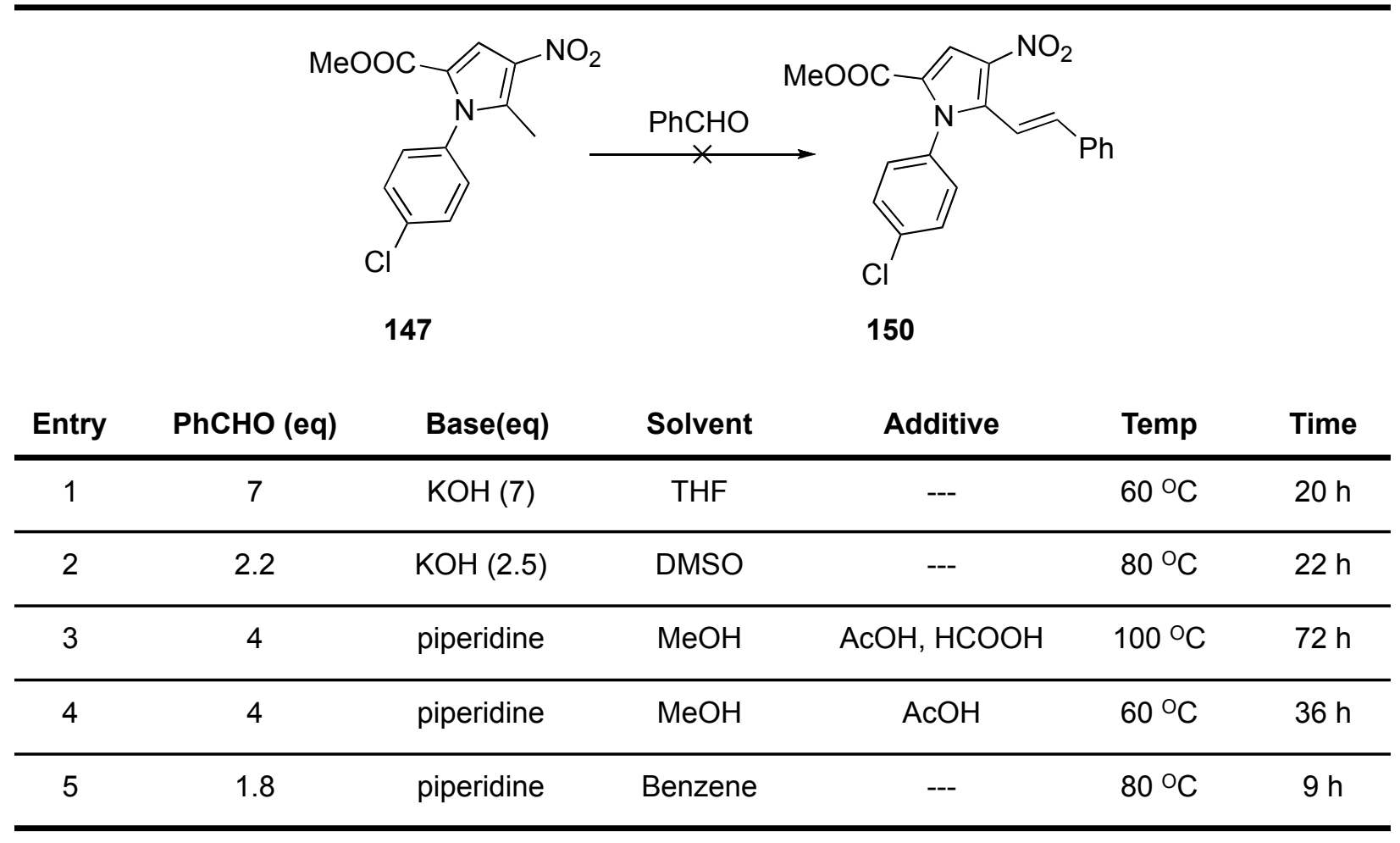

Table 13: Attempted condensation of (149) with benzaldehyde

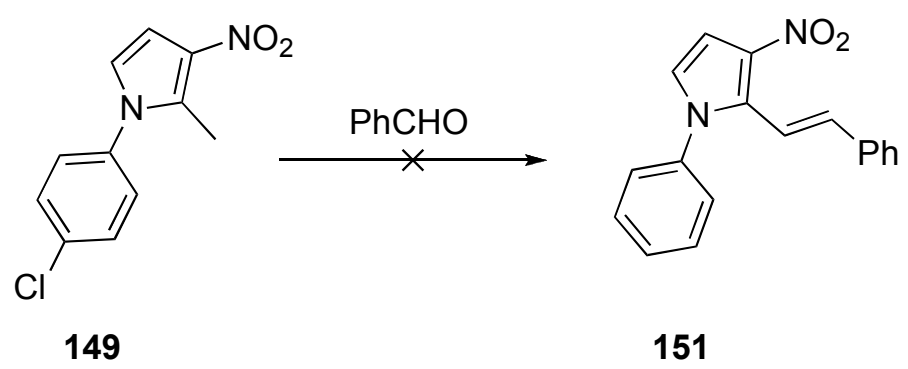

\begin{tabular}{cccccc} 
Entry & PhCHO (eq) & Base(eq) & Solvent & Temp & Time \\
\hline $1^{\text {a }}$ & 7 & $\mathrm{KOH} \mathrm{(7)}$ & DMSO & $60^{\circ} \mathrm{C}$ & 3.5 days \\
\hline $2^{\mathrm{b}}$ & 2.2 & $\mathrm{KOH}(2.5)$ & DMSO & $\mathrm{RT}$ & $3 \mathrm{~h}$ \\
\hline $3^{\mathrm{a}}$ & 4 & $\mathrm{KOH}(4)$ & DMSO & $60^{\circ} \mathrm{C}$ & $72 \mathrm{~h}$ \\
\hline
\end{tabular}

a Products unidentified

b Recovered the starting material 149 
The synthesis of 3-nitro-4-(2-phenylethynyl)pyrrole (155) by Albert van Leusen et. al from the nitro-diene 154 and TosMIC (tosyl methylisocyanide) has provided another pyrrole substrate to test the feasibility of heteroannulation conditions. ${ }^{67}$ The nitro-diene 154 required for this synthesis was prepared by the Henry reaction between cinnamaldehyde (152) and nitromethane (153).68

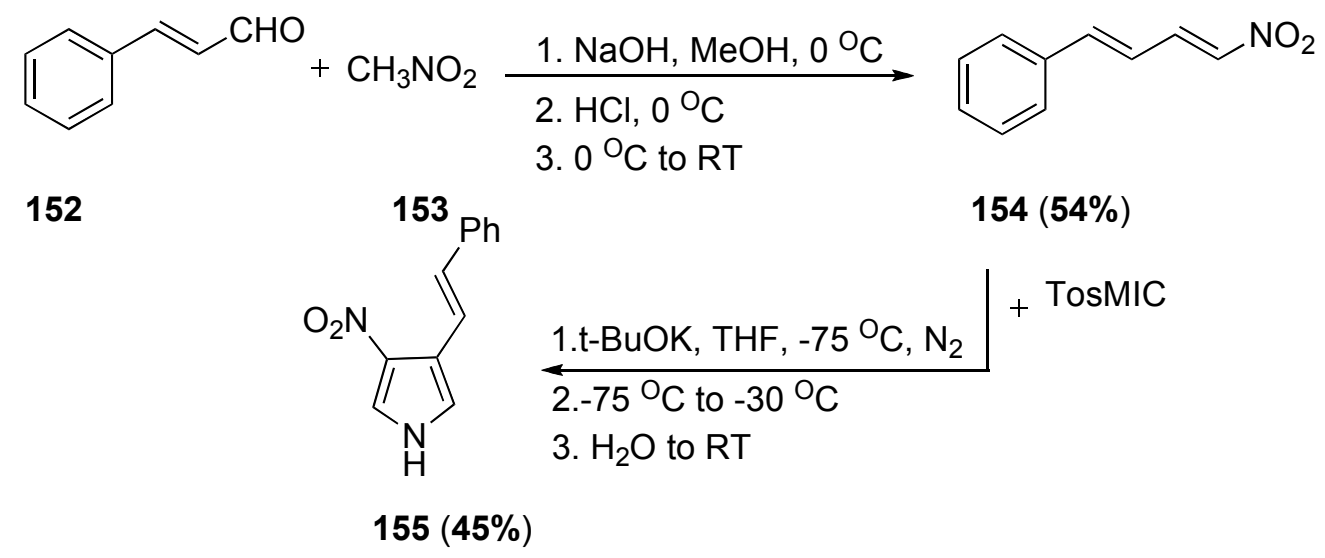

\section{Scheme 35: Synthesis of 3-nitro-4-(2-phenylethynyl)pyrrole}

The pyrrole 155 was then converted into the $\mathrm{N}$-methylpyrrole derivative (156) via a phase transfer catalyzed methylation, ${ }^{67}$ and also the tosyl derivative (Scheme 36 ).

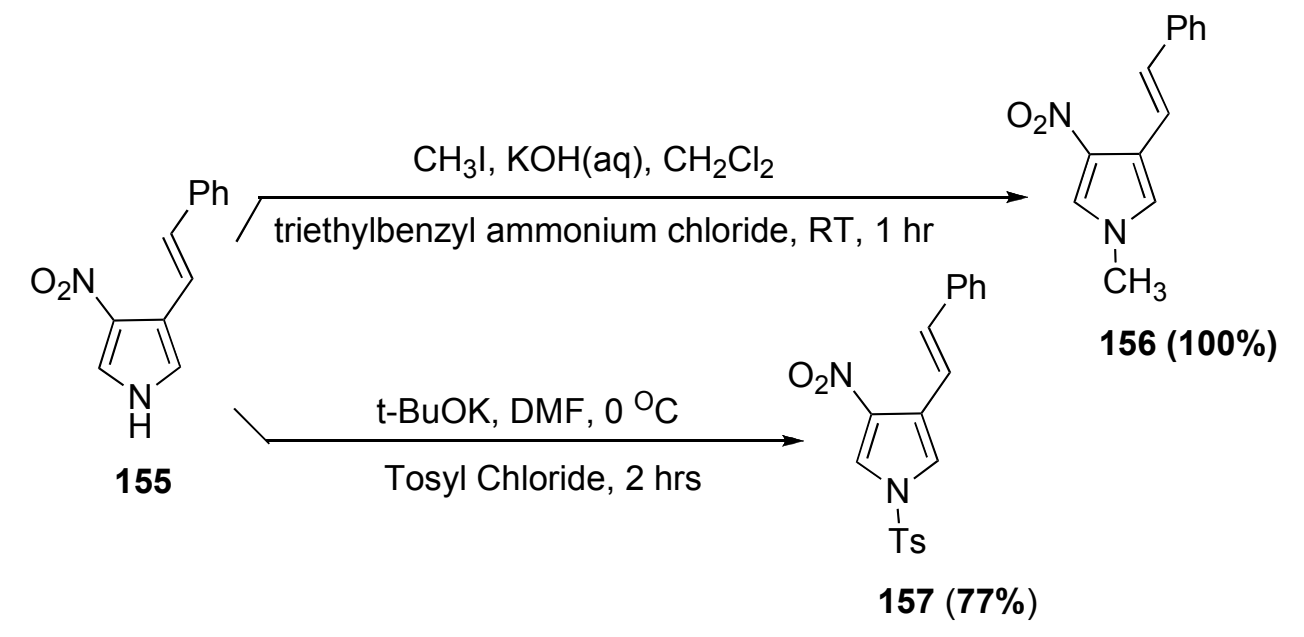

Scheme 36: Preparation of $\mathrm{N}$-methyl and $\mathrm{N}$-tosyl derivatives of 3-nitro-4-(2phenylethynyl)pyrrole 
Despite having an ideal pyrrole precursor, the heteroannulation conditions did not yield the desired pyrrolopyrrole 158; the precursor 156 was recovered unchanged in the two attempts (Table 14). Even the choice of having an N-tosyl derivative 157 proved unsuccessful with the formation of some unidentified substances (Entry $2 \& 3$ Table 14).

Table 14: Attempted heteroannulation on N-methyl- and N-tosyl-3-nitro-4-(2phenylethynyl)pyrrole

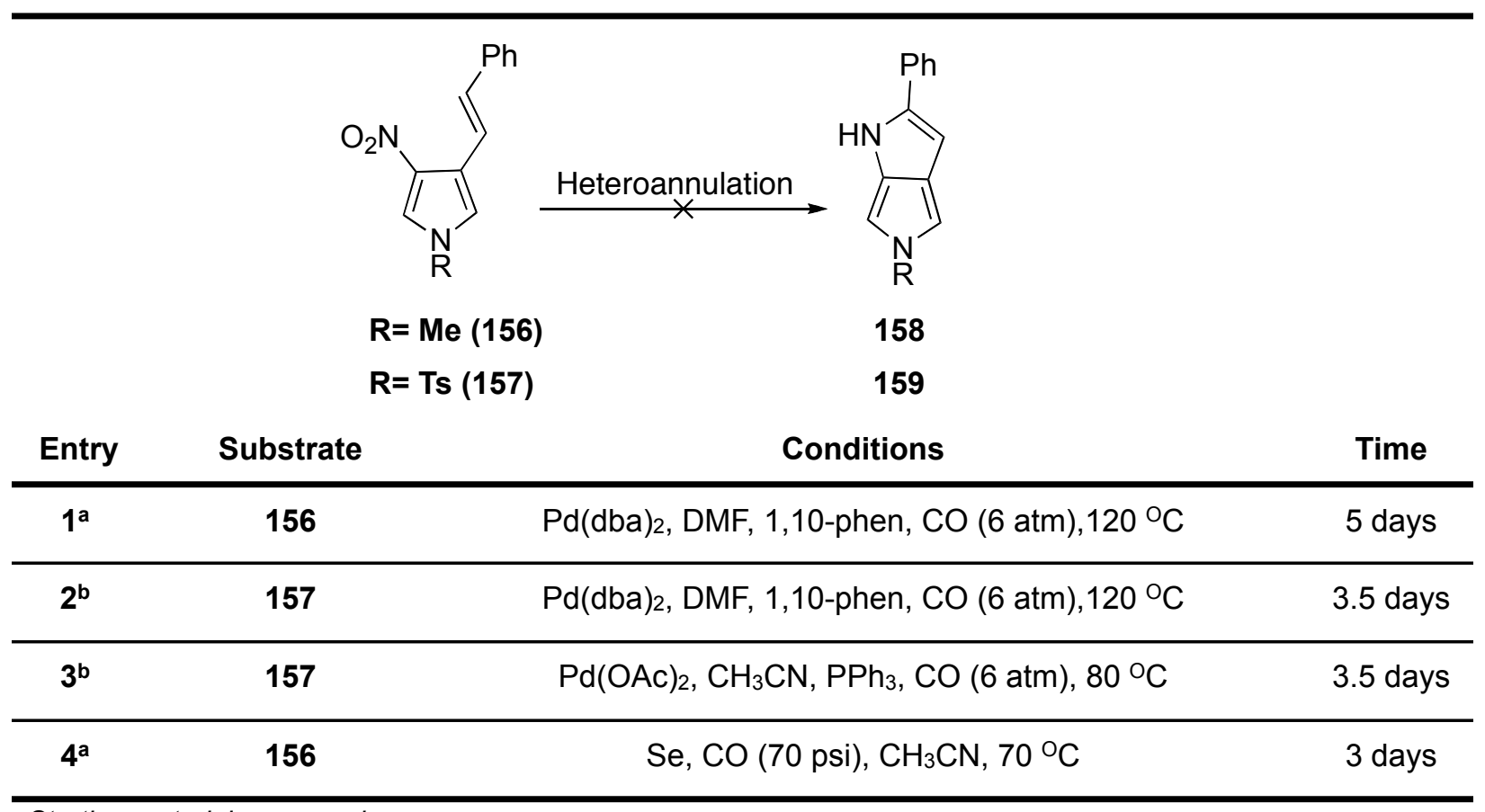

a Starting material recovered

b Unidentified products

\subsection{Conclusion:}

The syntheses of several fused $(5,5)$ pyrroloheterocyclic systems such as the thieno[2,3-b]pyrrole, thieno[3,2-b]pyrrole, furo[3,2-b]pyrrole, pyrrolo[3,2-d]thiazole, and the two isomeric pyrroloimidazoles has been accomplished through the palladiumcatalyzed reductive $\mathrm{N}$-heteroannulation reaction. In addition to these compounds, a 
thienodipyrrole derivative was also synthesized. Despite the success in the aforesaid systems, the heteroannulation methodology was unsuccessful in the synthesis of the pyrrolopyrrole and the pyrroloisoxazole analogues. The reason behind the recovery of the precursor 3-methyl-4-nitro-5-styrylisoxazole in all the heteroannulation attempts remains unclear. Quite so, the difficulty in the preparation of 2-styryl-3-nitropyrrole derivatives has further impaired any conclusive evidence to account for the failure in the synthesis of the pyrrolo[3,2-b]pyrrole system. 


\section{Chapter 2}

\section{Palladium-Catalyzed Synthesis of Isatins}

\subsection{Introduction to isatin chemistry:}

The history of isatin dates back to 1841 when Erdmann ${ }^{69}$ and Laurent ${ }^{70}$ prepared isatin(indole-2,3-dione) (161) independently by the oxidation of indigo (160) with chromic and nitric acids. Although regarded as a synthetic compound for more than a century, isatin's existence in nature was found in the fruits of the cannon ball tree Couroupita quianensis Aubl and in Calanthe discolor LINDL. ${ }^{11}$ It is also reported as a metabolite derivative of adrenaline in humans and as a component in the parotid gland secretions of Bufo frogs. ${ }^{71}$<smiles>O=C1/C(=C2/Nc3ccccc3C2=O)Nc2ccccc21</smiles>

160

\section{Figure 8: Indigo}

The chemistry of isatins emerged as an offspring to the intense research in the branch of indigo chemistry during the late nineteenth century. Baeyer reported the formation of dioxindole (161), along with isatide (162), a white substance when isatin was reduced. Further reduction of dioxindole in presence of hot zinc oxide gave oxindole (163) and finally, indole (96) (Scheme 37). ${ }^{71}$ 


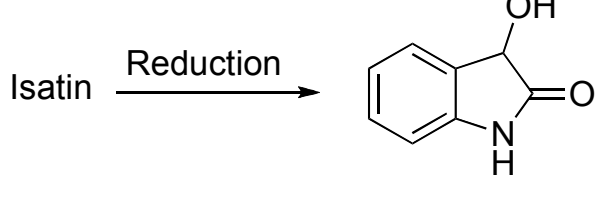

161<smiles>O=C1Nc2ccccc2C1(O)C1(O)C(=O)Nc2ccccc21</smiles>

162

\section{Reduction}

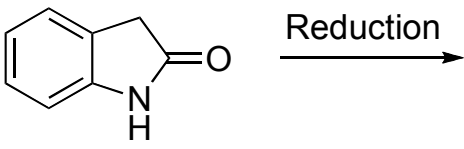

163<smiles>c1ccc2[nH]ccc2c1</smiles>

96

\section{Scheme 37: The stepwise reduction of isatin to indole as recorded by Baeyer}

The ability of isatin to dissolve in an alkali to form the salt of isatinic acid (165) inspired Kekule to suggest that isatinic acid was o-aminobenzoylformic acid and that isatin (164) was its internal anhydride. Baeyer realized Kekule's proposition, and saw the relationship of dioxindole and oxindole to isatin. This led Baeyer to formulate his synthesis of isatin in 1878 by the oxidation of oxindole ${ }^{73}$ and also to propose two structures for isatin: the "stable" lactam isatin (164) and the "labile" lactim isatin (166) (Figure 9). ${ }^{71}$<smiles>O=C1Nc2ccccc2C1=O</smiles>

164

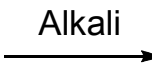<smiles>Nc1ccccc1C(=O)C(=O)[O-]</smiles>

165

Scheme 38: The reaction behind Kekule's proposition<smiles>O=C1Nc2ccccc2C1=O</smiles>

164<smiles>O=C1C(O)=Nc2ccccc21</smiles>

166

Figure 9: The two proposed structures of isatin by Baeyer 


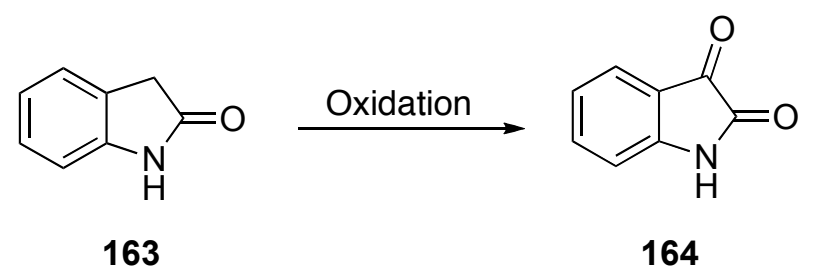

\section{Scheme 39: The first preparation of isatin}

Eventually, Baeyer synthesized isatin by boiling o-nitrophenylpropiolic acid with alkali in $1878 .{ }^{72}$

\subsection{Significant isatin syntheses:}

The discovery of isatin, an orange crystalline solid has spawned a multitude of reactions pertaining to its synthesis. This section summarizes some of the well-known syntheses of isatin.

\section{2 (a) Claisen and Shadwel isatin synthesis ${ }^{73}$ :}

One of the earliest preparatory routes to isatin was a three step synthesis from onitrobenzoylchloride (167) developed in 1879. Known as the Claisen and Shadwel's synthesis, the first step was the conversion of o-nitrobenzoylchloride (167) into the nitrile by the action of $\mathrm{KCN}$, which was successively treated with $\mathrm{HCl}$ and $\mathrm{KOH}$ to afford the potassium salt of o-nitrophenylglyoxalic acid (isatinic acid) (168). Reduction of 168 in an alkaline medium to the potassium salt of o-aminophenylglyoxalic acid (169) as the second step, was ultimately followed by an acid treatment to complete the formation of isatin. In this manner, Claisen and Shadwel's synthesis substantiated the structure of isatin as suggested by Kekule (Scheme 40). 


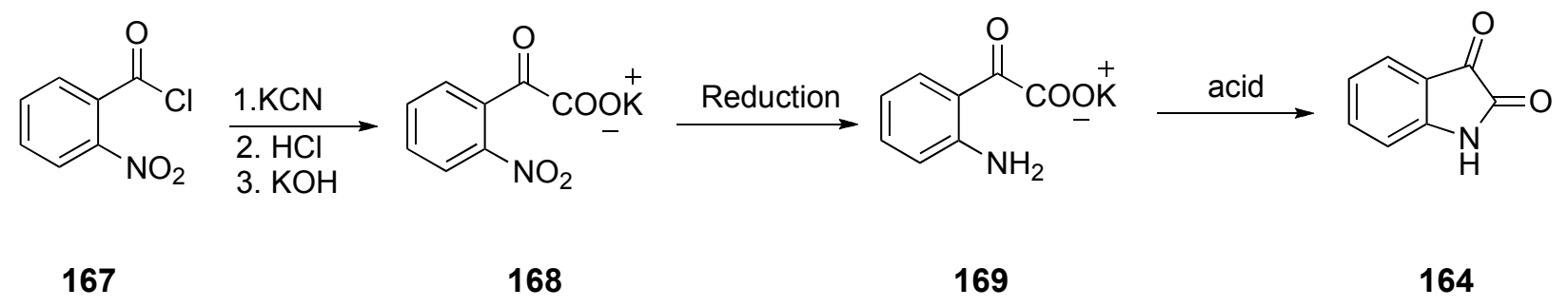

Scheme 40: Claisen and Shadwel isatin synthesis

\section{2 (b) Sandmeyer's syntheses:}

Sandmeyer's method ${ }^{74}$ of synthesizing isatin and many of isatin derivatives tends to be the favorite of many synthetic organic chemists even today. This reaction begins from an aniline 170, being treated with chloral hydrate and hydroxylamine in presence of aqueous sodium sulfate to form an intermediate isonitrosoacetanilide 171. The subsequent conversion of 171 to isatin 164, when treated with sulfuric acid or less frequently polyphosphoric acid completes the sequence of Sandmeyer's synthesis (Scheme 40). Several substituted anilines have been successfully converted into the corresponding isatins, usually in high yields. The advantage of this method lies in the fact that the reagents are cheap and easily available. For example, isatin (164) was prepared in $>75 \%$ yields; ${ }^{72}$ however, methyl-3-aminobenzoate (170x) afforded the corresponding methyl-4-isatincarboxylate $(\mathbf{1 6 4 x})$ in a low yield of $34 \% .{ }^{75}$ The drawback of this method lies in the inefficiency to prepare nitroisatins from nitroisonitrosoacetanilides and also in the formation of two isomers from metasubstituted anilines. 
$\overbrace{\mathrm{NH}_{2}} \frac{\mathrm{CCl}_{3} \mathrm{CHO} \cdot \mathrm{H}_{2} \mathrm{O}}{\mathrm{NH}_{2} \mathrm{OH} . \mathrm{HCl}, \text { aq } \mathrm{Na}_{2} \mathrm{SO}_{4}}$

170

170x (R= 3-COOMe)

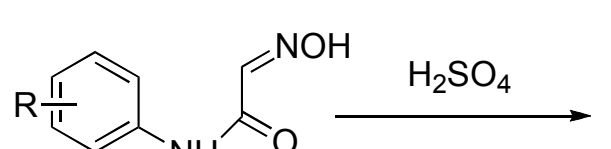

171<smiles>O=c1[nH]c2cc[R]ccc=2c1=O</smiles>

$164(\mathrm{R}=\mathrm{H})$

164x (R=4-COOMe)

\section{Scheme 41: The Sandmeyer synthesis}

A second method developed by Sandmeyer to synthesize isatins, generally referred to as "Sandmeyer's diphenylurea isatin synthesis", ${ }^{72}$ begins with a reaction between a symmetrical diphenylthiourea (172) and potassium cyanide in the presence of lead carbonate to form a cyanoformamidine (173). The next step is the reduction of 173 with ammonium sulfide and subsequent ring closure to isatin-2-anil (175) in presence of sulphuric acid; The ring closure to isatin-2-anil (175) could also be accomplished with aluminium chloride in the presence of benzene or carbon disulfide. An acid catalyzed hydrolysis of isatin-2-anil (175) afforded the desired isatin (164) (Scheme 42).

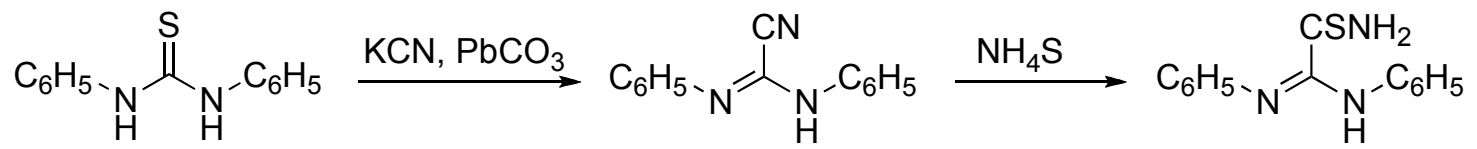

172 173 174
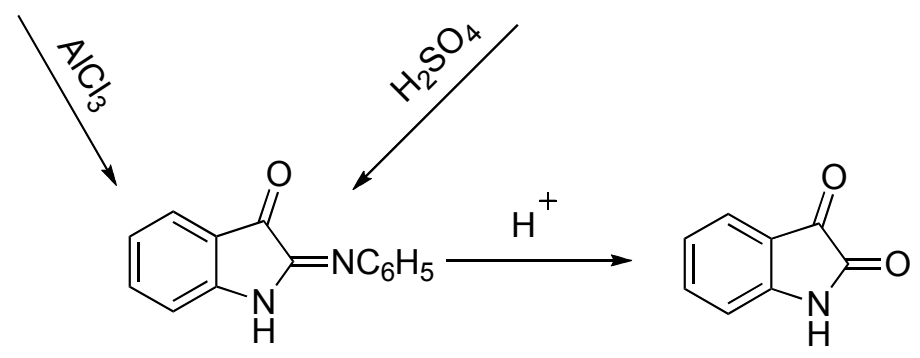

175

Scheme 42: Sandmeyer's diphenylurea isatin synthesis 


\section{2 (c) Stolle's synthesis:}

An alternative to Sandmeyer's synthesis is the Stolle's method (Scheme 43). This synthesis involves the reaction between the aniline (170) and oxalyl chloride to form the intermediate chlorooxalylanilide (176), which cyclized to the corresponding isatin in the presence of a Lewis acid, usually aluminium chloride or $\mathrm{BF}_{3} . \mathrm{Et}_{2} \mathrm{O}$ or $\mathrm{TiCl}_{3}{ }^{76}$ This reaction was particularly useful in the synthesis of 1-aryl and polycyclic isatins. ${ }^{72}$ An application of this reaction is seen in the synthesis of Melostatin A, although in low yields. ${ }^{77}$

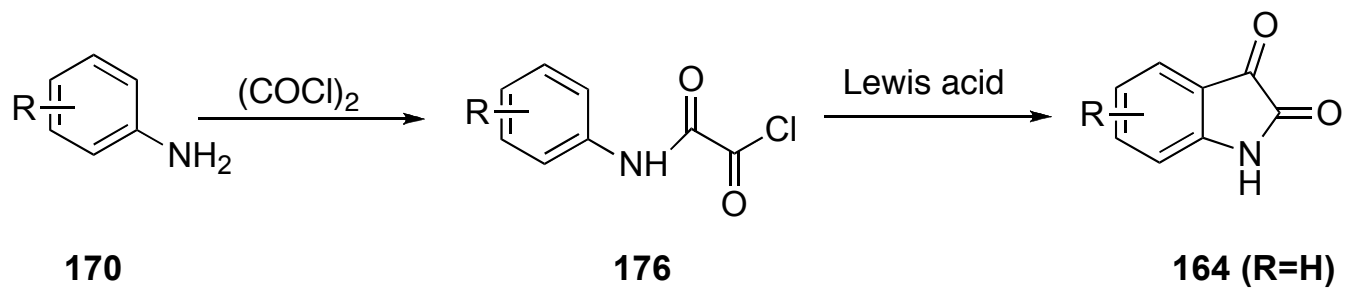

\section{Scheme 43: Stolle's isatin synthesis}

\section{2 (d) The Martinet isatin synthesis ${ }^{72,73,78}$ :}

The Martinet synthesis features a condensation between an aromatic amine and an oxomalonate ester (meso-oxalic acid esters) (178) in the presence of an acid to yield a 3-(3-hydroxy-2-oxindole)carboxylic acid derivative (179), which upon oxidative decarboxylation affords the desired isatin (Scheme 44). This method was successfully applied to synthesize 5,6-dimethoxyisatin (180) from 4-aminoveratrole (177), but was less successful when applied to 2,4-dimethoxyanilne. ${ }^{72}$ 


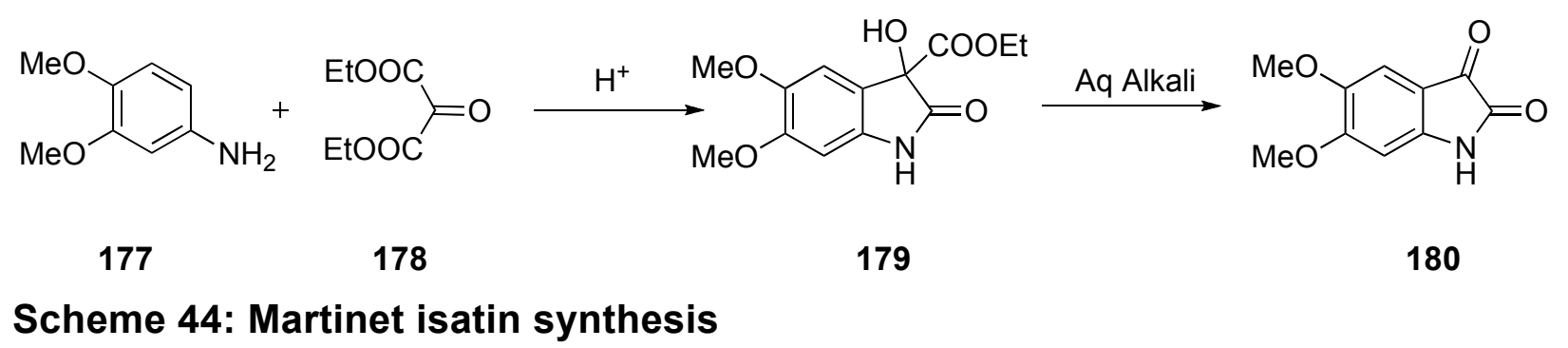

\section{2 (e) Gassman synthesis:}

Another general procedure was developed by Gassman and his group ${ }^{79}$ in the late nineteen seventies. Although rarely used, this procedure deserves to be mentioned because of a different pathway, wherein a sulphur compound was used en route to isatins. The applicability to anilines with a broad spectrum of electron-withdrawing and electron-donating substituents offers an additional advantage of this reaction. The synthetic sequence begins with the preparation of a 3-methylthio-2-oxindole (176) from a substituted aniline (170). Subsequent chlorination of the 3-methylthio-2oxindole 176 with NCS followed by hydrolysis yields the corresponding isatin. Two methods were designed to synthesize the 3-methylthio-2-oxindole (176), and the method of choice depends upon the substituents on the aromatic ring. With electronwithdrawing groups substituted on the aromatic ring, the synthesis of the oxindole derivative was achieved via an $\mathrm{N}$-chloroaniline intermediate 171 , which further reacts with a methylthioacetate ester (172) to give the azasulfonium salt (174) (Method 1). In the case of electron donating substituents, the azasulphonium salt 174 was synthesized by reacting the aniline with the chlorosulfonium salt (173) (Method 2).

The reaction is believed to proceed through a proton abstraction from the azasulfonium salt $\mathbf{1 7 4}$ to form an intermediate sulphur ylide $\mathbf{1 7 5}$, which undergoes a 
Sommelet-Hauser rearrangement, followed by ring closure, to afford the 3methylthio-2-oxindole 176.

Method 1

Method 2

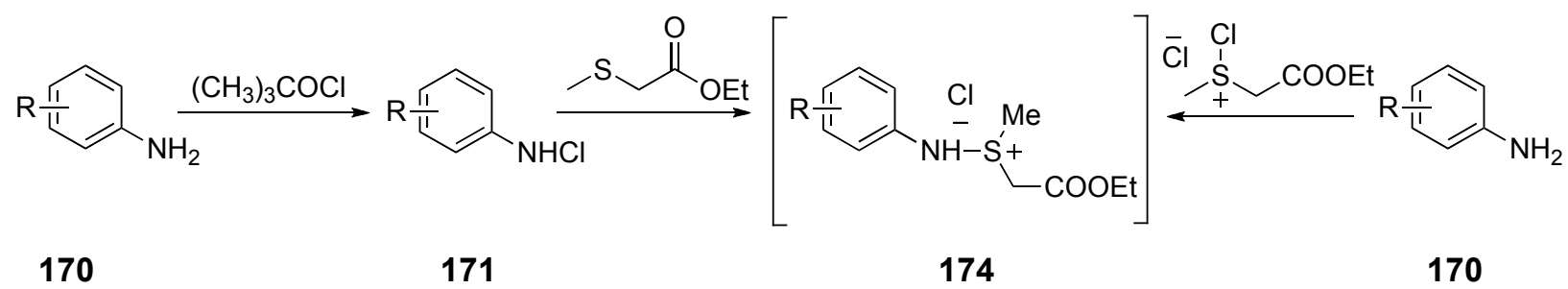<smiles>CCNCC</smiles>

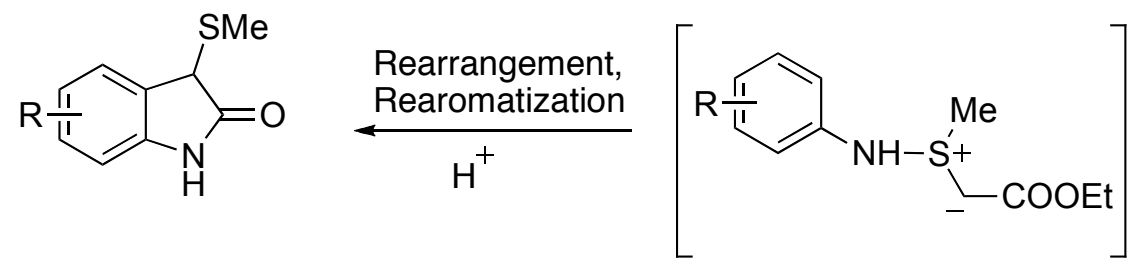

176

175

NCS<smiles>O=C1Nc2cc[R]#cc2C1([Si])Cl</smiles>

177

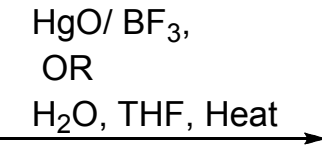<smiles></smiles>

$164(\mathrm{R}=\mathrm{H})$

Scheme 45: Gassman's isatin synthesis

\subsection{Miscellaneous Syntheses:}

A considerable number of less frequently employed procedures have been developed by several of researchers for the preparation of isatin and isatinderivatives. One of those less frequently referred syntheses is the Reissert's synthesis 
of isatin, documented in 1904. This reaction involves the formation of isatin from thiooxanilide in the presence of sulphuric acid (Scheme 46). ${ }^{80}$

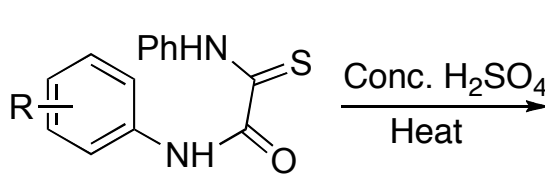

178<smiles>O=c1[nH]c2cc[R]ccc=2c1=O</smiles>

$164(\mathrm{R}=\mathrm{H})$

\section{Scheme 46: Reissert isatin synthesis}

A relatively recent method, published in 1994, is based upon the directed orthometalation of N-pivaloyl- and N-Boc anilines. ${ }^{81}$ The dianions formed are trapped with diethyloxalate and the isatins are obtained after deprotection and cyclization of the intermediate ketoesters 186 under acidic conditions (Scheme 47). This method has the advantage of being regioselective when meta-substituted anilines with metalation directing groups such as OMe are used.

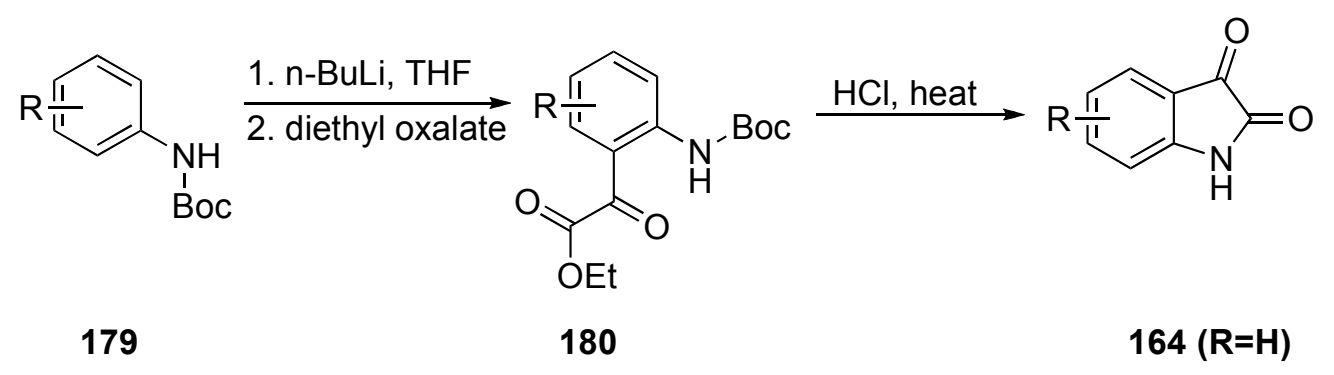

\section{Scheme 47: Isatins via metalation of anilide derivatives}

Another report describes the synthesis of isatins via a lithium-halogen exchange reaction of ortho-bromophenylureas. Carbonylation and subsequent cyclization afforded the respective isatins in good yields. ${ }^{82}$ 


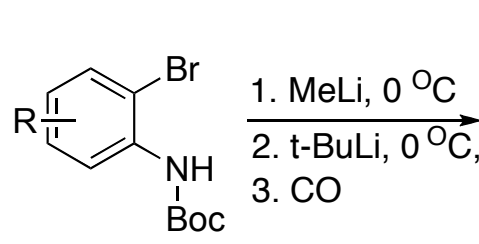

181

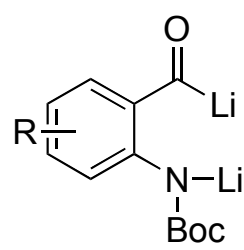

182 $\frac{\text { 1. } \mathrm{CO}}{\text { 2. } \mathrm{H}_{3} \mathrm{O}^{+}}$<smiles>O=C1Nc2cc[R1]cc2C1=O</smiles>

$164(\mathrm{R}=\mathrm{H})$

\section{Scheme 48: Isatins via lithium assisted carbonylation}

There have been several articles pertinent to the oxidation of indoles by chromic acid as a preparatory route to isatins. A recent article by Yadav and his group described an indium chloride catalyzed, IBX (2-iodoxybenzoic acid) mediated oxidation of indoles to isatins in excellent yields. ${ }^{83}$ Another noteworthy preparation of isatin involving a mild oxidation of 3-bromoindole (183) with $\mathrm{N}$-bromosuccinimide through the formation of the intermediate 3,3-dibromo-2-oxindole (186) has been reported by Parrick and coworkers. Facile hydrolysis of the intermediate 186 in aqueous methanol afforded the isatin in high yield. ${ }^{84}$ This strategy was applied to obtain 4- and 6-substituted isatins from the hydrolysis of the corresponding 3,3dihalo-2-oxindoles (Scheme 49). ${ }^{85}$<smiles>Cc1[nH]c2ccccc2c1Br</smiles>

183<smiles>CC(C)CC(C)O</smiles>

184<smiles>O=C1Nc2ccccc2C1Br</smiles>

185

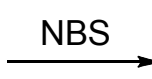<smiles>O=C1Nc2ccccc2C1(Br)Br</smiles>

186

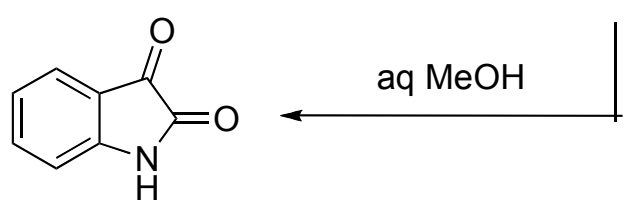

\section{Scheme 49: Oxidation of indole to isatin with NBS}


The use of a palladium in the synthesis of isatins has been demonstrated by Yamamoto and his coworkers. The synthetic sequence describes the "palladiumcatalyzed double carbonylation" of ortho-haloacetanilides (187) in the presence of diethylamine to yield the corresponding $\alpha$-ketoamide 188. The $\alpha$-ketoamide afforded the isatin (164) in nearly quantitative yield upon acid hydrolysis (Scheme 50). ${ }^{86}$

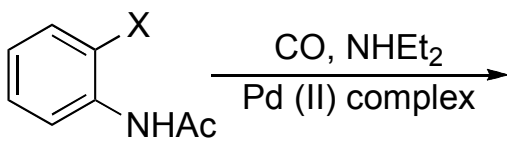

187<smiles>CCN(CC)C(=O)C(=O)c1ccccc1NC(=O)O</smiles>

188

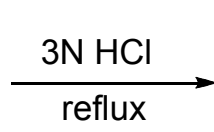<smiles>O=C1Nc2ccccc2C1=O</smiles>

164

\section{Scheme 50: Isatins via palladium-catalyzed double carbonylation}

\subsection{The significance of isatin:}

The ability to display a wide variety of biological activities has established isatin as a 'versatile starting material' in the design and synthesis of several new compounds. Isatin has been found as an endogenous material in mammalian tissues. The presence of both the keto and the lactam groups in isatins has led to numerous reactions of which reduction and nucleophillic addition at the C-3 keto group are of potential interest. The property of isatins to yield indoles on reduction has been applied in the synthesis of substituted ellipticine derivatives. ${ }^{87}$ Partial reduction of isatins yields dioxindole and oxindole. An acid catalyzed reaction between isatin (164) and oxindole (163) gives isoindigo (189), which is diastereoselectively converted into diazacrisenodiones (191) via reduction and subsequent rearrangement of the intermediate 190 (Scheme 51). ${ }^{71}$ 
<smiles>O=C1Nc2ccccc2C1=O</smiles>

164<smiles>O=C1Cc2ccccc2N1</smiles>

163 $\underset{\text { Heat }}{\stackrel{\mathrm{AcOH}, \mathrm{HCl}}{\longrightarrow}}$<smiles>CCC=CC=C1C(=O)Nc2ccccc21</smiles>

189<smiles>O=C1Nc2ccccc2C1C1C(=O)Nc2ccccc21</smiles>

190<smiles>O=C1Nc2ccccc2[C@@H]2C(=O)Nc3ccccc3[C@H]12</smiles>

191

\section{Scheme 51: Reaction between isatin and oxindole}

Isatin was used as the starting material in the synthesis of the analgesic drug, pemedolac (195). The precursor to this drug, an indole derivative, was synthesized from isatin and methyl-3-phenylpropionate (192). This reaction was initiated by a C3 alkylation to yield a dioxoindole derivative (193), which was reduced to the corresponding indole (194) (Scheme 52). 


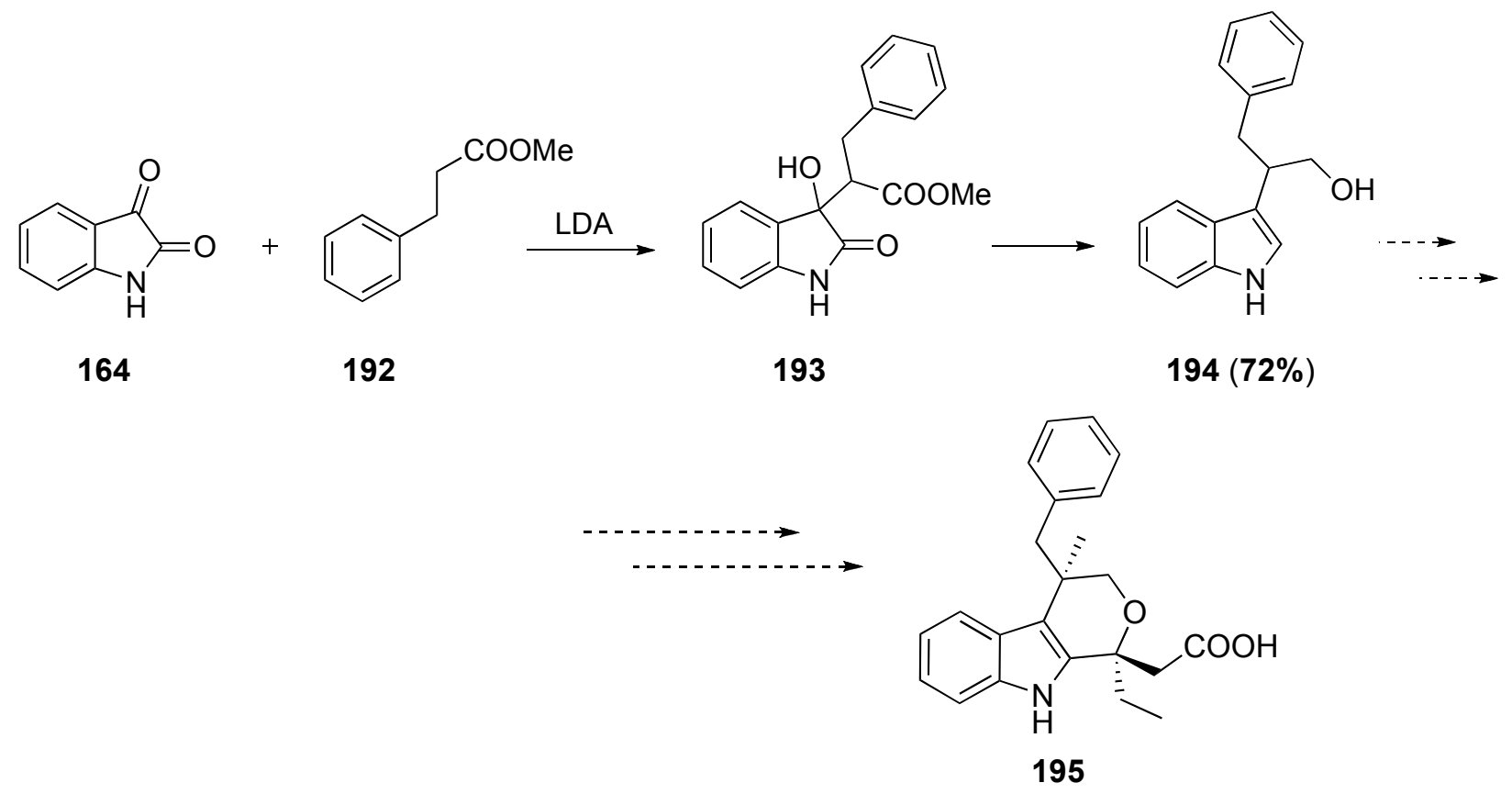

Scheme 52: The intermediate to Pemedolac

A similar reaction sequence was used in the synthesis of the alkaloid, Hobertine (198). ${ }^{71}$<smiles>O=C1Nc2ccccc2C1=O</smiles>

164

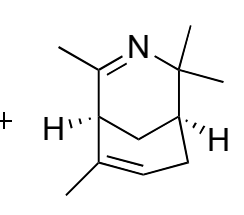

196
$\underset{\mathrm{EtOH}}{\stackrel{\text { Piperidine }}{\longrightarrow}}$

$$
\text { EIOH }
$$

Scheme 53: Synthesis of Hobertine

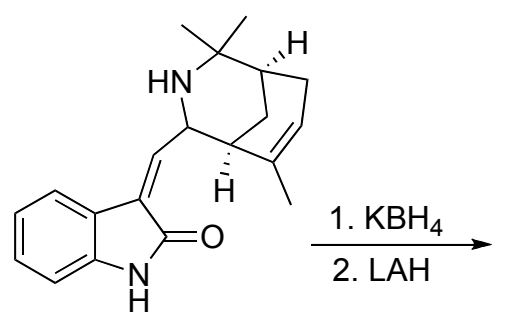

$197(86 \%)$

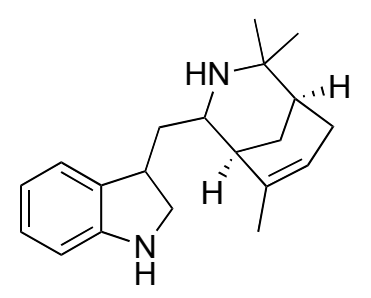

$198(25 \%)$

Isatin reacts with hydroxylamine and hydrazine derivatives to give the expected condensation products, but the reaction with ammonia led to the formation of isamic acid (201) and isamide (202). Although these products were known since 1876, it was not until 1976 that their actual structures were elucidated by Sir John Cornforth. 88 Isamic acid is structurally regarded as a dimer formed from the reaction between two 
molecules of isatin and one molecule of ammonia. The formation of isatin imine, from a condensation in the first step, followed by the imine attack on the second molecule of isatin, would lead to an intermediate $\mathbf{2 0 0}$ that is ultimately transformed into isamic acid 201. This transformation is assumed to proceed via lactamization and subsequent ring opening and re-closure by an internal nucleophillic attack. A second equivalent of ammonia converts the acid into the amide 202 (Scheme 54).<smiles>O=C1Nc2ccccc2C1=O</smiles>

164<smiles>[14CH2][Mg]</smiles><smiles>C1=CCCC=C1</smiles>

199

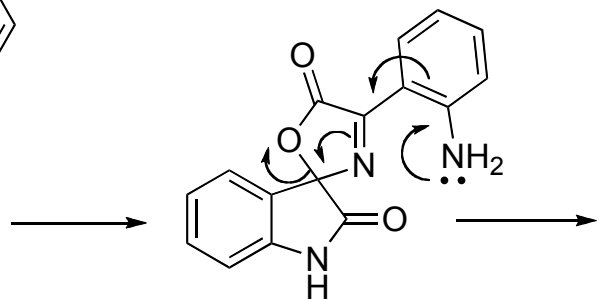

200<smiles>O=C(O)C1=NC2(Nc3ccccc31)C(=O)Nc1ccccc12</smiles>

201<smiles>NC(=O)C1=NC2(Nc3ccccc31)C(=O)Nc1ccccc12</smiles>

202

\section{Scheme 54: The reaction between isatin and ammonia}

Contrary to the expected nucleophillic attack at $\mathrm{C} 3$, the reaction between ammonia and $\mathrm{N}$-acetylisatin (203) occured with a nucleophillic attack at $\mathrm{C} 2$ resulting in a ring opening reaction. The benzoylformamide (204) obtained as the product further reacts with a second equivalent of ammonia to yield the quinazoline derivative (205) (Scheme 55). ${ }^{71}$ 


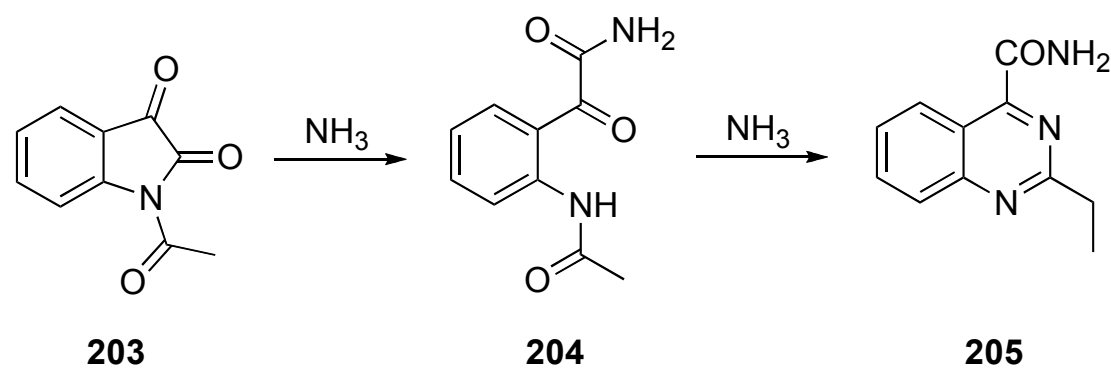

Scheme 55: The reaction between $\mathrm{N}$-acetylisatin and ammonia

Oxidizing agents like hydrogen peroxide or chromic anhydride oxidize isatin to isatoic anhydride (206), which condenses with proline to afford a pyrrolo[1,4]benzodiazepine ring (207), a structural pattern found in antineoplastics $(\text { Scheme 56) })^{71}$.<smiles>O=C1Nc2ccccc2C1=O</smiles>

164<smiles>O=c1[nH]c2ccccc2c(=O)oc1=O</smiles>

206<smiles>CCCCCCCCCCCC(=O)O</smiles>

207

\section{Scheme 56: The pyrrolo[1,4]benzodiazepine ring synthesis}

Known as the 'Pfitzinger reaction' in organic chemistry, the reaction between isatin (164) and acetone in presence of an aqueous alkali to give quinoline-4-carboxylic acid (cinchoninic acid) (211) was first published by Pfitzinger in $1886 .{ }^{89}$ Since its discovery, there have been numerous articles wherein isatin and its derivatives were reacted with several ketones to generate a series a cinchoninic acid derivatives. ${ }^{90}$ The generally accepted mechanism for this reaction involves the hydrolysis of the amide bond of isatin to form the salts of isatoic acid (169) that condense with the ketones to form the salt of the enamine (208). The salt undergoes cyclization and dehydration to 
yield the desired 4-quinoline-carboxlic acids as the salts (210), which are hydrolyzed with an acid, usually acetic acid to form the desired products (Scheme 57). The Pfitzinger reaction has also been carried out with a-acetoxyacetophenones, in which case 3-hydroxy-quinoline-4-carboxylic acids were obtained. Articles with hydrazides and enaminones leading to 4-carboxamido-quinoline-3-carboxylates as well as imidines, which lead to 2-aminoquinoline-4-carboxamides were also reported.<smiles>O=C1Nc2ccccc2C1=O</smiles>

164<smiles>C[18O]</smiles><smiles>Nc1ccccc1C(=O)C(=O)[O-]</smiles>

169<smiles>CCC(C)=O</smiles><smiles>[I-]</smiles><smiles>[Mg]</smiles><smiles>Cc1cc(C(=O)O)c2ccccc2n1</smiles>

\section{Scheme 57: The Pfitzinger reaction}

A large number of isatin applications are listed in several scientific journals, including those in medicine and pharmacy. The use in colorimetry, owing to the property of isatin to form coloured substances with certain amino acids and steroids and also the use in catalysis, when complexed with transition metals, are some of the miscellaneous applications worth mentioning. 


\subsection{Results and discussion:}

As a result of the success encountered in the synthesis of indoles and pyrroloheterocycles via the "palladium-catalyzed reductive $\mathrm{N}$-heteroannulation methodology', the similar annulation conditions of palladium diacetate $(6 \mathrm{~mol} \%)$, triphenylphosphine and carbon monoxide ( 6 atm) were tried by a former student Chet Howerton on a new substrate, 2-(2-bromoethynyl)-1-nitrobenzene (212a). ${ }^{91} \mathrm{He}$ observed that $212 \mathrm{a}$ was completely consumed within an hour at $70^{\circ} \mathrm{C}$ yielding a new product, identified as isatin (Scheme 58).

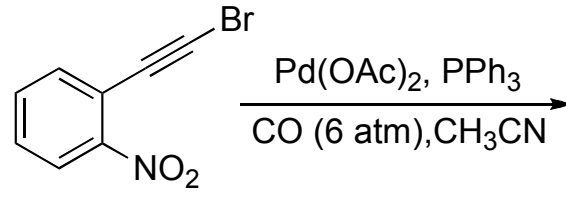

212a<smiles>O=C1Nc2ccccc2C1=O</smiles>

$164(35 \%)$

\section{Scheme 58: The discovery of the palladium-catalyzed synthesis of isatin}

Reflecting upon the unique position isatin occupies in the annals of medicinal and organic chemistry, this reaction was subjected to further investigation. Executing the reaction in the absence of carbon monoxide, nevertheless resulted in the formation of isatin, indicating that carbon monoxide was not a requirement in this reaction (Table 15). The addition of benzoquinone as an oxidant did not produce any remarkable change except when THF was used as the solvent (Table 15, Entry 6). When this reaction was performed in the presence of triphenylphosphine in water, without any palladium catalyst at room temperature, isatin was obtained after $24 \mathrm{~h}$ in a low yield along with the acetylene 213 . This result indicated that palladium does indeed catalyze the formation of isatin from its precursor $212 \mathbf{a}$ (Scheme 59). 


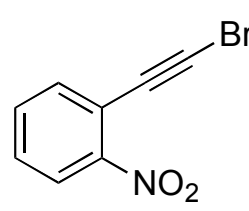

212a

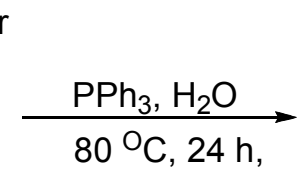

$80^{\circ} \mathrm{C}, 24 \mathrm{~h}$

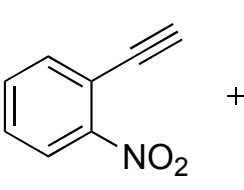

213<smiles>O=C1Nc2ccccc2C1=O</smiles>

$164(10 \%)$

Scheme 59: The reaction behind the necessity of palladium to catalyze the isatin formation

This reaction was then tested with a variety of solvents and two other palladium catalysts, bis(acetonitrile)palladiumchloride $\left[\mathrm{PdCl}_{2}(\mathrm{MeCN})_{2}\right]$ and bis(triphenylphosphine)palladiumchloride $\left[\mathrm{PdCl}_{2}\left(\mathrm{PPh}_{3}\right)_{2}\right]$ under different conditions. The results of this study are presented in Table 15. Isatin was obtained in all the cases, but was either in low yield, or was contaminated with some inseparable material in most attempts. The reaction was also examined with the chloro and iodo analogues (212b and 212c) (Table 15, entry $14,16,17,18)$. The best result was observed when the temperature was $60^{\circ} \mathrm{C}$ with the solvent as acetone and $\mathrm{PdCl}_{2}\left(\mathrm{PPh}_{3}\right)_{2}$ as the catalyst, wherein isatin was obtained in a yield of $83 \%$ (Entry 16). With this observed result, iodo-alkynes were chosen as the "substrate of choice" with $\mathrm{PdCl}_{2}\left(\mathrm{PPh}_{3}\right)_{2}$ as the catalyst and acetone as the solvent. 


\begin{tabular}{|c|c|c|c|c|c|c|c|}
\hline & & & $212 a(X$ & $=\mathrm{Br})$ & 64 & & \\
\hline Entry & $\mathbf{x}$ & Solvent ${ }^{a}$ & Catalyst (mol\%) & Additive & Temp & Time & Yield ${ }^{b}$ \\
\hline 1 & $\mathrm{Br}$ & $\mathrm{MeCN}$ & $\mathrm{Pd}(\mathrm{OAc})_{2}(10)$ & $\begin{array}{c}\mathrm{PPh}_{3}(40 \mathrm{~mol} \%) \\
\mathrm{CO}(4 \mathrm{~atm})\end{array}$ & $70^{\circ} \mathrm{C}$ & $1 \mathrm{~h}$ & $35 \%$ \\
\hline 2 & $\mathrm{Br}$ & $\mathrm{MeCN}$ & $\mathrm{Pd}(\mathrm{OAc})_{2}(10)$ & $\mathrm{CO}(4 \mathrm{~atm})$ & $70^{\circ} \mathrm{C}$ & $1 \mathrm{~h}$ & $11 \%$ \\
\hline 3 & $\mathrm{Br}$ & $\mathrm{MeCN}$ & $\mathrm{Pd}(\mathrm{OAc})_{2}(10)$ & ---- & $70^{\circ} \mathrm{C}$ & $4.5 \mathrm{~h}$ & $\sim 22 \%$ \\
\hline 4 & $\mathrm{Br}$ & $\mathrm{MeCN}$ & $\mathrm{Pd}(\mathrm{OAc})_{2}(10)$ & Benzoquinone (100 mol \%) & $70^{\circ} \mathrm{C}$ & $4 \mathrm{~h}$ & $\sim 42 \%^{c}$ \\
\hline 5 & $\mathrm{Br}$ & $\mathrm{MeCN}$ & $\mathrm{Pd}(\mathrm{OAc})_{2}(1)$ & Benzoquinone (100 mol \%) & $70^{\circ} \mathrm{C}$ & $22 \mathrm{~h}$ & $7 \%$ \\
\hline 6 & $\mathrm{Br}$ & THF & $\mathrm{Pd}(\mathrm{OAc})_{2}(10)$ & Benzoquinone (100 mol \%) & $70^{\circ} \mathrm{C}$ & $3.5 \mathrm{~h}$ & $52 \%$ \\
\hline 7 & $\mathrm{Br}$ & THF & $\mathrm{Pd}(\mathrm{OAc})_{2}(5)$ & --- & $65^{\circ} \mathrm{C}$ & $3.5 \mathrm{~h}$ & $10 \%$ \\
\hline 8 & $\mathrm{Br}$ & $\mathrm{MeCN}$ & $\mathrm{PdCl}_{2}(\mathrm{MeCN})_{2}(10)$ & ---- & $70^{\circ} \mathrm{C}$ & $3 \mathrm{~h}$ & $\sim 24 \% c$ \\
\hline 9 & $\mathrm{Br}$ & THF & $\mathrm{PdCl}_{2}(\mathrm{MeCN})_{2}(5)$ & ---- & $70^{\circ} \mathrm{C}$ & $3 \mathrm{~h}$ & $\sim 24 \% c$ \\
\hline 10 & $\mathrm{Br}$ & THF & $\mathrm{PdCl}_{2}\left(\mathrm{PPh}_{3}\right)_{2}(5)$ & --- & $65^{\circ} \mathrm{C}$ & $3.5 \mathrm{~h}$ & $\sim 44 \%^{c}$ \\
\hline 11 & $\mathrm{Br}$ & DMSO & $\mathrm{PdCl}_{2}\left(\mathrm{PPh}_{3}\right)_{2}(5)$ & ---- & $65^{\circ} \mathrm{C}$ & $3.5 \mathrm{~h}$ & $\sim 25 \% c$ \\
\hline 12 & $\mathrm{Br}$ & $\mathrm{CH}_{2} \mathrm{Cl}_{2}$ & $\mathrm{PdCl}_{2}\left(\mathrm{PPh}_{3}\right)_{2}(5)$ & --- & $65^{\circ} \mathrm{C}$ & $24 \mathrm{~h}$ & $\sim 48 \%{ }^{d}$ \\
\hline 13 & $\mathrm{Br}$ & Acetone & $\mathrm{PdCl}_{2}\left(\mathrm{PPh}_{3}\right)_{2}(5)$ & ---- & $\mathrm{rt}$ & $20 \mathrm{~h}$ & $48 \%$ \\
\hline 14 & $\mathrm{Cl}$ & Acetone & $\mathrm{PdCl}_{2}\left(\mathrm{PPh}_{3}\right)_{2}(5)$ & ---- & $\mathrm{rt}$ & $22 \mathrm{~h}$ & $47 \%$ \\
\hline 15 & $\mathrm{Br}$ & Toluene & $\mathrm{PdCl}_{2}\left(\mathrm{PPh}_{3}\right)_{2}(5)$ & ---- & $60^{\circ} \mathrm{C}$ & $20 \mathrm{~h}$ & $\sim 47 \%$ \\
\hline 16 & I & Acetone & $\mathrm{PdCl}_{2}\left(\mathrm{PPh}_{3}\right)_{2}(5)$ & --- & $60^{\circ} \mathrm{C}$ & $4 \mathrm{~h}$ & $83 \%$ \\
\hline 17 & 1 & Acetone & $\mathrm{PdCl}_{2}\left(\mathrm{PPh}_{3}\right)_{2}(5)$ & ----- & rt & $20 \mathrm{~h}$ & $73 \%$ \\
\hline 18 & I & Acetone & $\mathrm{AgNO}_{3}(5)$ & ---- & rt & $237 \mathrm{~h}$ & $11 \%$ \\
\hline
\end{tabular}

(a) 0.02-0.06 M solution of the substance (b) total consumption of the starting material (c) impure product obtained

(d) in a closed vessel 
The synthesis of 2-(2-bromoethynyl)-1-nitrobenzene (212a) was carried out in two steps from the commercially available ortho-iodonitrobenzene (214). The first step involved the preparation of 2-nitro-1-[2-(trimethylsilyl)ethynyl]benzene (216) utilizing the palladium(0) catalyzed "Sonagashira reaction"92 between 214 and trimethylsilylyethyne (215). The typical Sonagashira conditions: a palladium(0) complex and a halide salt of copper(I) were used with triethylamine as the solvent. The palladium( 0 ) complex used in our case was the tetrakis(triphenylphosphine)palladium generated in situ from $\mathrm{PdCl}_{2}\left(\mathrm{PPh}_{3}\right)_{2}$ and triphenylphosphine, and the product 2-nitro-1-[2-(trimethylsilyl)ethynyl]benzene (216) ${ }^{93}$ was obtained in almost quantitative yield. This compound was then transformed into desired 2-(2-bromoethynyl)-1-nitrobenzene (212a) in the presence of NBS and a catalytic amount of silver nitrate in DMF as the solvent (Scheme 60). ${ }^{94}$

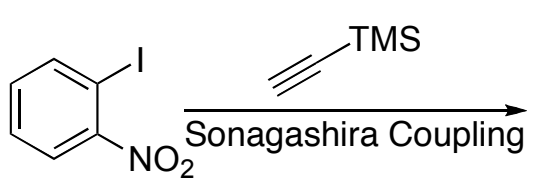

214

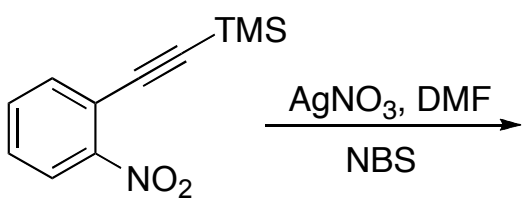

$216(\sim 100 \%)$<smiles>O=[N+]([O-])c1ccccc1C#CBr</smiles>

212a

\section{Scheme 60: The two step synthesis of 2-(2-bromoethynyl)-1-nitrobenzene (212a)}

A series of iodo-alkynes were then synthesized from a selection of orthoiodonitrobenzenes having both electron withdrawing and electron donating substituents, following the aforementioned sequence. The Sonagashira coupling products were obtained in good yields (80-99\%) for all substrates. However, it was found that the iodo-alkynes $(217 \mathrm{a} \ldots . \mathbf{2 1 7} \mathrm{g})$ were unstable and transformed into a red 
substance on standing at room temperature. Although most of them were beyond identity, the one obtained from the iodo-alkyne $\mathbf{2 1 7} \mathbf{d}$ was identified as the corresponding 2-iodoisatogen (249). This bright red solid was stable at room temperature, and its structure was confirmed by a single crystal X-ray analysis. The formation of this isatogen $\mathbf{2 4 9}$ was also observed when the TMS-alkyne $\mathbf{2 1 6 d}$ was treated with $\mathrm{NIS}-\mathrm{AgNO}_{3}$ under different catalyst loading and reaction times, at room temperature (Scheme 61). These results as recorded by us are presented in Table 16.<smiles>COc1ccc([N+](=O)[O-])c(C#CC(C)(C)O[Na])c1</smiles>

216d

217d<smiles></smiles>

249

Scheme 61: Formation of the 2-iodo-5-methoxyisatogen (249), alongside the iodoalkyne 217d

Table 16: The reaction conditions evaluated on 5-methoxy-2-nitro-1[2-(trimethylsilyl)ethynyl]benzene (216d)

\begin{tabular}{|c|c|c|c|c|}
\hline Entry & $\mathrm{AgNO}_{3}$ & Time & $217 d$ & 249 \\
\hline 1 & $50 \mathrm{~mol} \%$ & $1 \mathrm{hr}$ & $77 \%$ & ----- \\
\hline 2 & $50 \mathrm{~mol} \%$ & $5 \mathrm{hr}$ & ----- & $23 \%$ \\
\hline 3 & $100 \mathrm{~mol} \%$ & $5 \mathrm{~min}$ & $95 \%$ & ----- \\
\hline 4 & $5 \mathrm{~mol} \%$ & $24 \mathrm{hr}$ & ----- & $83 \%$ \\
\hline
\end{tabular}


The obtained iodoalkynes were ultimately treated with $\mathrm{PdCl}_{2}\left(\mathrm{PPh}_{3}\right)_{2}(5 \%)$ in acetone, under an inert atmosphere and at ambient temperature, and the corresponding isatins were obtained in moderate yields (Table 17). It was, however, the pyridine derivative (220), which failed to yield the corresponding 4-azaisatin. An unidentified orange substance was formed in all attempts.

Table 17: The sequential conversion of 2-halonitrobenzenes to the corresponding isatins

\begin{tabular}{|c|c|c|c|c|c|}
\hline Entry & & \multicolumn{4}{|c|}{ Sonagashira Coupling-------------- lodination--------------------- Isatin } \\
\hline 1 & 214a & $\mathrm{R}=4-\mathrm{NO} 2$ & $216 a$ & $217 \mathbf{a}^{1}(89 \%)$ & $164 a(47 \%)$ \\
\hline 2 & 214b & $\mathrm{R}=4-\mathrm{Cl}$ & 216b & $217 b^{1}(89 \%)$ & $164 b(47 \%)$ \\
\hline 3 & 214c & $\mathrm{R}=4-\mathrm{OMe}$ & 216c & $217 c^{1}(77 \%)$ & $164 c(59 \%)$ \\
\hline 4 & 214d & $\mathrm{R}=5-\mathrm{OMe}$ & 216d & $\mathbf{2 1 7} \mathbf{d}^{1}(77 \%)$ & $164 d(61 \%)$ \\
\hline 5 & 214e & $\mathrm{R}=3-\mathrm{Me}$ & $216 e$ & $217 e^{1,2}(93 \%)$ & 164 e $(79 \%)$ \\
\hline 6 & $214 f$ & $\mathrm{R}=4-\mathrm{Me}$ & $216 f$ & $217 f^{1}(73 \%)$ & $164 f(59 \%)$ \\
\hline 7 & $214 \mathrm{~g}$ & $\mathrm{R}=6-\mathrm{Me}$ & $216 \mathrm{~g}$ & $\mathbf{2 1 7 g ^ { 1 } ( 9 3 \% )}$ & $164 \mathrm{~g}(34 \%)$ \\
\hline 8 & & 18 & & $220(69 \%)$ & ----- \\
\hline
\end{tabular}

1 The compounds decompose on standing at room temperature

2 The compound decomposes on attempted purification on silica.

Taking into account the availability of the inexpensive 6-nitropiperonal (221) and foreseeing the method to convert it into the corresponding isatin, the precursor 
bromoalkyne $\mathbf{2 2 3}$ was synthesized in two steps: a Corey-Fuchs reaction ${ }^{95}$ as the first step to give the dibromide $\mathbf{2 2 2}$, and a cesium carbonate mediated dehyrobromination as the second step. The precursor bromoalkyne $\mathbf{2 2 3}$ thus obtained gave the expected 5,6-methylenedioxyisatin (224) in 35\% yield in the presence of $\mathrm{PdCl}_{2}\left(\mathrm{PPh}_{3}\right)_{2}$ and acetone (Scheme 62).

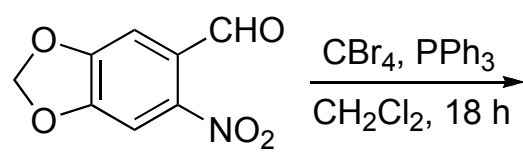

221

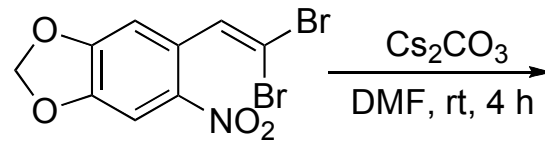

222

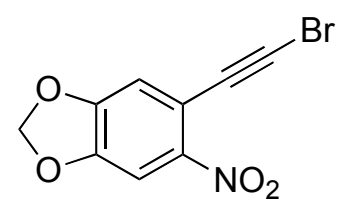

223

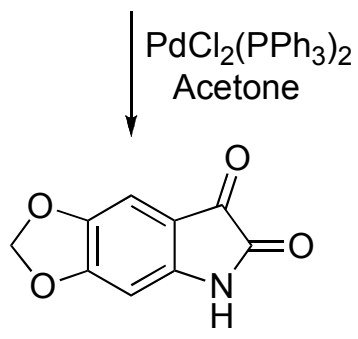

224

\section{Scheme 62: Preparation of 5,6-methylenedioxyisatin (224)}

A notable observation during the conversion of the iodoalkynes to isatins was a gradual colour change of the reaction mixture from yellow to orange, and then to red. Having identified the isatogen $\mathbf{2 4 9}$ as the transformed product from the iodoalkyne $\mathbf{2 1 7} \mathbf{d}$, an analysis of the reaction at the intermediate "orange-colour" stage was attempted.

The bromoalkyne 212a was refluxed in dichloromethane with $\mathrm{PdCl}_{2}\left(\mathrm{PPh}_{3}\right)_{2}(10 \%)$ at $45^{\circ} \mathrm{C}$ for 80 minutes under an inert atmosphere. The orange solution was cooled to room temperature, the solvent evaporated, and the crude was quickly purified by flash chromatography. The product obtained was an orange solid, which gradually changed 
to isatin at room temperature. The spectroscopic analysis of this orange solid indicated it to be 2-bromoisatogen (225) (Scheme 63).

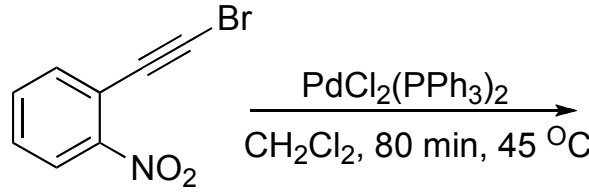

212a<smiles></smiles>

225

\section{Scheme 63: Formation of 2-bromoisatogen (225)}

\subsection{Isatogens:}

Isatogens, also known as 2-substituted-3H-indole-3-one-1-oxides were first described by Baeyer during his years of research on indigo in $1881 .{ }^{96}$ The parent isatogen 227 reported by Baeyer was the 2-carboxylic acid ethylester (227), prepared by the action of cold sulphuric acid on the o-nitrophenylpropiolic acid ethylester (226) (Scheme 64).

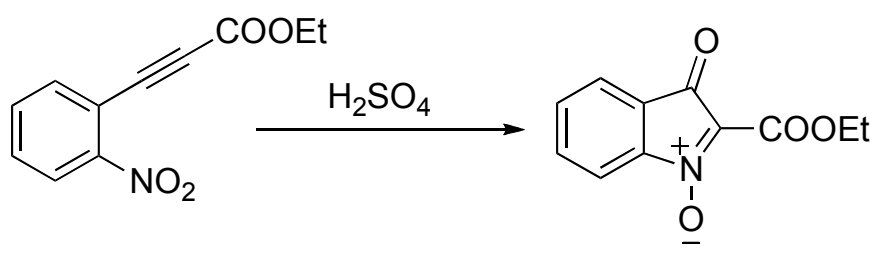

226

227

\section{Scheme 64: Baeyer's synthesis of the "parent isatogen"}

Synthetic routes to 2-aryl-substituted isatogens have been reported from "alkynic derivatives". One of the reported reactions involved a coupling between the 2ethynylbenzene 228 and ortho-iodonitrobenzene (214) under the Stephen-Castro conditions to yield the (o-nitrophenyl)phenylacetylene (229), which cyclized to 2- 
phenylisatogen (230). A recent publication utilized the Sonagashira conditions on the same substrate and the isatogen $\mathbf{2 3 0}$, was isolated as the product after 3-4 days in good yield. ${ }^{97}$ The same procedure was successful in preparing the 2-pyridyl isatogen 233 in good yield (Scheme 65).

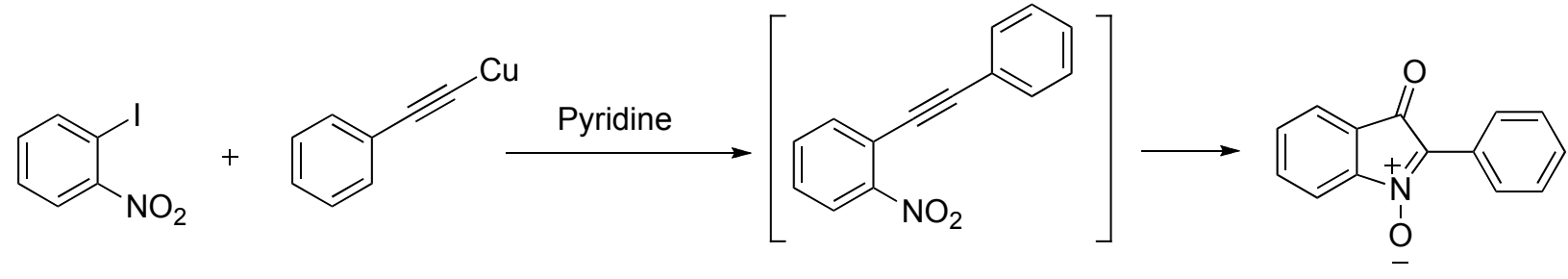

214

228 229 $230(65 \%)$<smiles>O=[N+]([O-])c1ccccc1I</smiles><smiles>C#Cc1ccccn1</smiles>

231

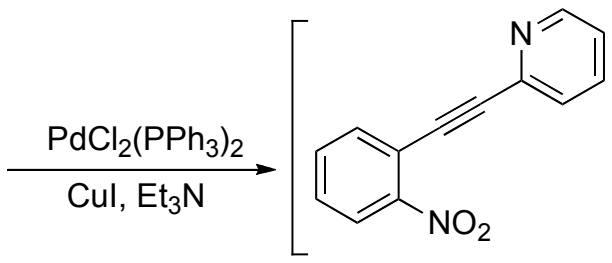

232<smiles>O=C1C(c2ccccn2)=[N+]([O-])c2ccccc21</smiles>

214 $233(70 \%)$

Scheme 65: Stephen-Castro conditions and Sonagashira conditions leading to the isatogen

A reaction that involves an ultraviolet irradiation of pyridinium ethanol derivatives 236, prepared from 2-nitrobenzaldehydes 234 and benzyl pyridinium salts 235 to form 2-arylistogens 236, has been developed by Krohnke and his coworkers. ${ }^{98}$ These isatogens $\mathbf{2 3 8}$ were also obtained by the action of a base on vinylpyridinium salts $\mathbf{2 3 7}$, the dehyrated products of the pyridinium ethanol derivatives 236 (Scheme 66). 
<smiles>CC(C)C(=O)c1ccccc1C(O)C(c1ccc([N+](=O)[O-])cc1)[n+]1ccccc1</smiles>

234

235

236

$238(91 \%)$

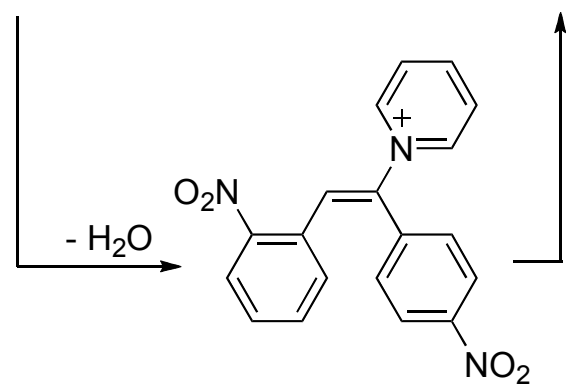

237

Scheme 66: Krohnke's isatogen synthesis

Alternately, photochemical transformations of 2-nitrophenylalkyne derivatives have also been published. ${ }^{99}$ Oxidation of 2-substituted indolines provides another route to isatogens. Indolines, usually obtained by the reduction of 2-substituted indoles with sodium cyanoborohydride, were oxidized to the corresponding isatogens in the presence of $\mathrm{m}-\mathrm{CPBA}$.

Bond and Hooper have reported the formation of 2-phenylisatogen (230) in high yield from the peracid oxidation of the corresponding N-hydroxy-2-phenylindole (239) (Scheme 67). ${ }^{100} \mathrm{~A}$ direct oxidation of 2-phenylindole to 2-phenylisatogen (230) via oxidation with Mimoun's reagent $\left(\mathrm{MoO}_{5}-\mathrm{HMPA}\right)$ deserves to be mentioned as $\mathrm{MoO}_{5}$ was found to exhibit this property only when complexed with HMPA (Scheme 68). ${ }^{101}$ 


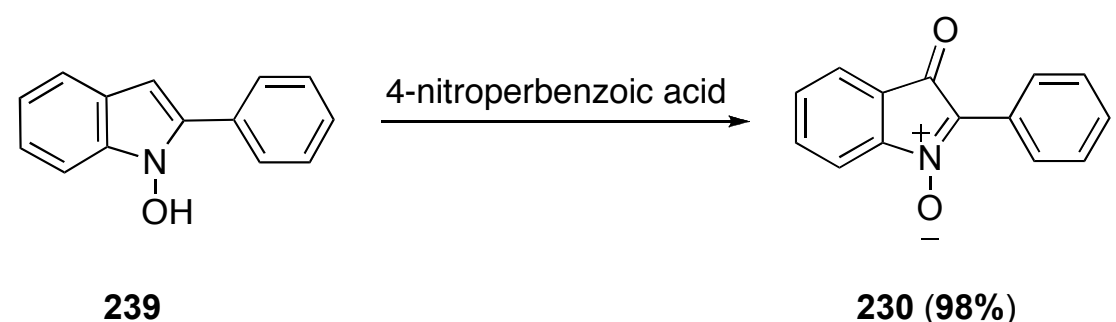

\section{Scheme 67: Bond and Hooper's isatogen synthesis}

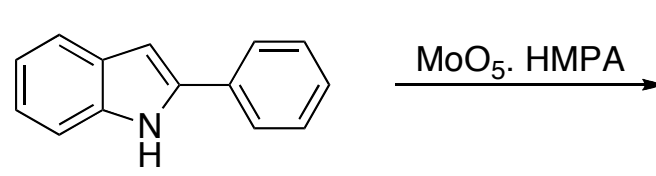

240

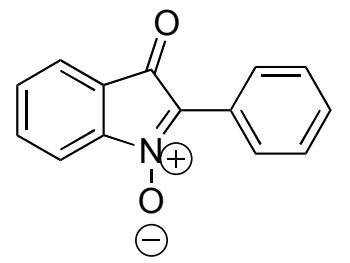

230

\section{Scheme 68: Isatogen synthesis with Mimon's reagent}

Interest in isatogens has been due to their biological activities against a range of bacteria and fungi. Some isatogens have been known to inhibit the synthesis of ATP from mitochondrial preparations. ${ }^{102}$ Isatogens were also suggested as spin trap adducts for trapping hydroxyl and superoxide radicals. ${ }^{109}$ The redox potentials of isatogens are comparable to naphthaquinones and benzoquinones; a property that renders them as good oxidizing agents. ${ }^{103}$

The ability of isatogen to exhibit reactivities at both the nitrone and carbonyl groups is apparent from its structure. This has instigated a study on the reactivity of these compounds, an outcome of which has been the formation of ring expansion products. The reaction carried out by Noland and Jones on the 2-phenylisatogen (230) with ammonia in presence of ethanol gave 3-phenyl-4-cinnolinol-1-oxide (244), which was reduced to 3-phenyl-4-cinnolinol (245). This transformation has been visualized as a nucleophillic attack of $\mathrm{NH}_{3}$ on $\mathrm{C}-2$, followed by a ring-cleavage to form the 
intermediate nitroso-derivative 242. A second intramolecular nucleophillic attack would lead to a ring closure to give the intermediate $\mathbf{2 4 3}$ which would undergo air-oxidation to the 1-oxide 244 (Scheme 69). ${ }^{104}$<smiles>O=C1C(=O)[N+]([O-])c2ccccc21</smiles>

230

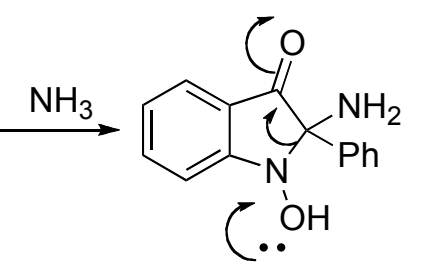

241<smiles>Cc1ccc(N(C)c2ccccc2)c(O)c1-c1ccccc1</smiles>

242<smiles>OC1=C(c2ccccc2)NN(O)c2ccccc21</smiles>

243<smiles>[TeH]</smiles><smiles>Oc1c(-c2ccccc2)nnc2ccccc12</smiles><smiles>CCCCCC#N</smiles><smiles>[O-][n+]1nc(-c2ccccc2)c(O)c2ccccc21</smiles>

244

Scheme 69: Ring expansion reaction of 2-phenylisatogen with $\mathrm{NH}_{3}$

A different type of ring expansion was encountered with trichloacetonitrile in xylene and phenylacetylene as two separate reactions. The products observed were a quinazolinone derivative (246) and 3-phenyl-4-quinolinol (247) respectively (Scheme 70). ${ }^{105}$ 


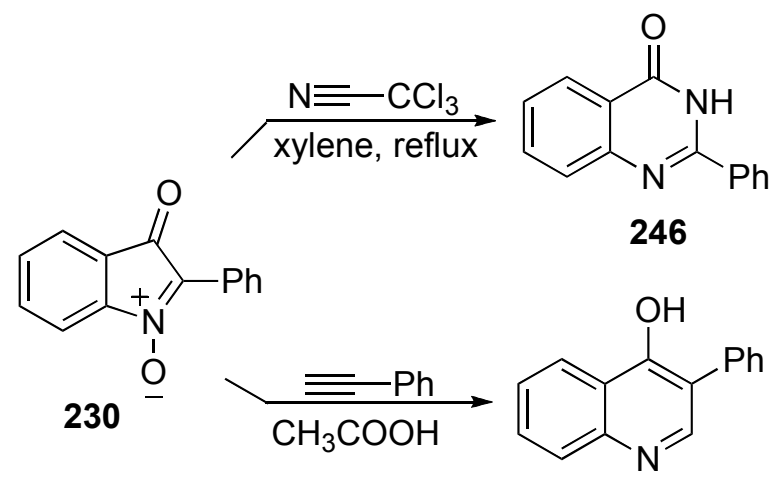

247

\section{Scheme 70: Ring expansion reactions of 2-phenylisatogen}

On the other hand, nucleophillic additions at the carbonyl carbon were very rare, with only Grignard's reagents and organolithiums reacting predominantly at the carbonyl site to yield the corresponding alcohols. This result substantiates the nature of the nitrone group as a potential site of a nucleophillic attack, as is evident from the structure.

An overview of the reactivity of isotogens encountered so far in literature portrays them as interesting intermediates. To our knowledge, 2-haloisatogens have not been reported in literature to date. Taking into consideration the isolation of the two isatogens 249 and $\mathbf{2 2 5}$, an attempt was made by Chet Howerton to isolate the corresponding isatogens from all the prepared iodo-alkynes, $212 \mathrm{a}$ and $\mathbf{2 1 7}(\mathrm{a}-\mathrm{g})$. These attempts were unsuccessful, as the isolated orange intermediates either displayed signs of decomposition immediately after purification or were contaminated with the respective isatin. The only stable isatogen, apart from 249 and 225 was 248 , obtained in $85 \%$ yield along with a trace of the isatin when the solution of compound 223 in acetone was reacted with $\mathrm{PdCl}_{2}\left(\mathrm{PPh}_{3}\right)_{2}$ for 50 minutes at room temperature 
(Scheme 71). Unlike the 2-bromoisatogen 225, this compound was stable enough at room temperature to carry out the respective chemical analysis.

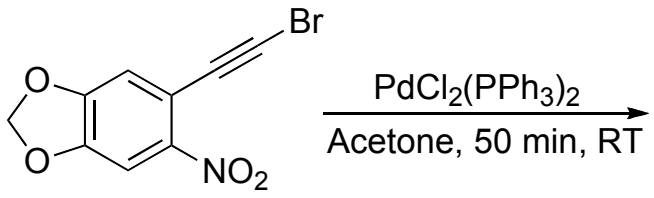

223<smiles>O=C1C(Br)=[N+](O)c2cc3c(cc21)OCO3</smiles>

$248(85 \%)$

\section{Scheme 71: The preparation of 2-bromo-5,6-methylenedioxyisatogen (248)}

An auric bromide catalyzed cyclization of o-(arylalkynyl)nitrobenzenes to the 2-arylisatogens has been developed by Yamamoto et al. ${ }^{106}$ Intrigued by the success of this $\mathrm{AuBr}_{3}$-catalyzed reaction, the similar reaction was done on compound 212a. The reaction was followed by TLC. With no progress after 20 hours, the reaction was allowed to stir for 4 days, wherein a red substance was isolated from the crude in a low yield. The spectral data showed traces of isatin contaminated with some substance, most probably the isatogen. The low yield of a contaminated product, after 4 days has led us to believe that the conditions developed by Yamamoto et al. are not ideal for the conversion of $212 a$ to isatin or the isatogen (Scheme 72 ).

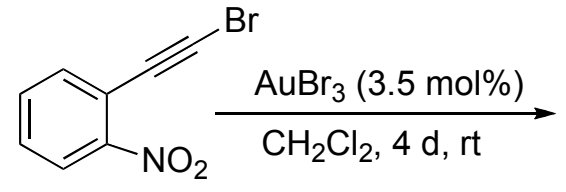

212a<smiles>O=C1Nc2ccccc2C1=O</smiles>

164 (low yield, contaminated)

\section{Scheme 72: The attempted auric bromide catalyzed reaction}

As the carbon atom of the nitrone group is prone to be attacked by nucleophiles, the likeliness of substituting the halogen by a suitable nucleophile cannot be overlooked. 
A test reaction was performed on the 2-bromoisatogen (225) by allowing it to stir in ethanol for 24 hours, under an inert atmosphere. Purification of the crude afforded the 2-ethoxyisatogen as a yellow solid in an excellent yield of $90 \%$ (Entry 1, Table 17). However, the reaction with allyl alcohol proved to be unsatisfactory with the corresponding allyloxyisatogen obtained in low yield along with the isatin (Table 17). A one pot reaction carried out on 1-(2-bromoethynyl)-2-nitrobenzene 212a in dichloromethane as a solvent with $\mathrm{Pd}\left(\mathrm{PPh}_{3}\right)_{2} \mathrm{Cl}_{2}(10 \%)$ and ethanol also afforded the 2-ethoxyisatogen (250a) in 70\% yield within 3 hours. As an ultimate example, 4chloro-2-nitro-1-(2-iodoethynyl)benzene (212c) was dissolved in dichloromethane and reacted with $\mathrm{Pd}\left(\mathrm{PPh}_{3}\right)_{2} \mathrm{Cl}_{2}(10 \%)$ and ethanol. However, this reaction afforded the corresponding 2-ethoxy-6-chloroisatogen (250c) in a low yield of $23 \%$ after 6 hours (Scheme 73).

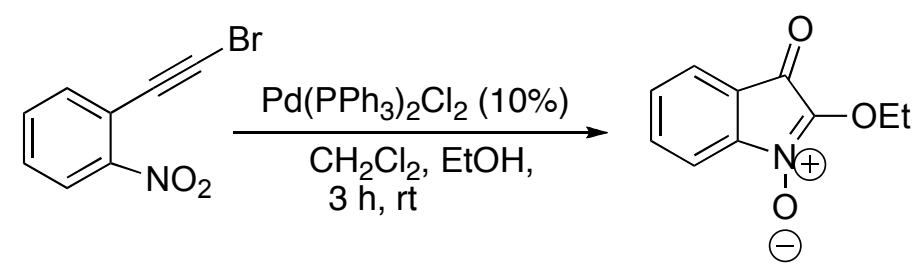

212a<smiles>O=[N+]([O-])c1cc(Cl)ccc1C#CBr</smiles>

212c
$250 a(70 \%)$<smiles>CCOC1C(=O)c2ccc(Cl)cc2[N+]1[O-]</smiles>

$250 \mathrm{c}(23 \%)$

Scheme 73: The one pot synthesis of 2-ethoxyisatogens, 250a and 250c 


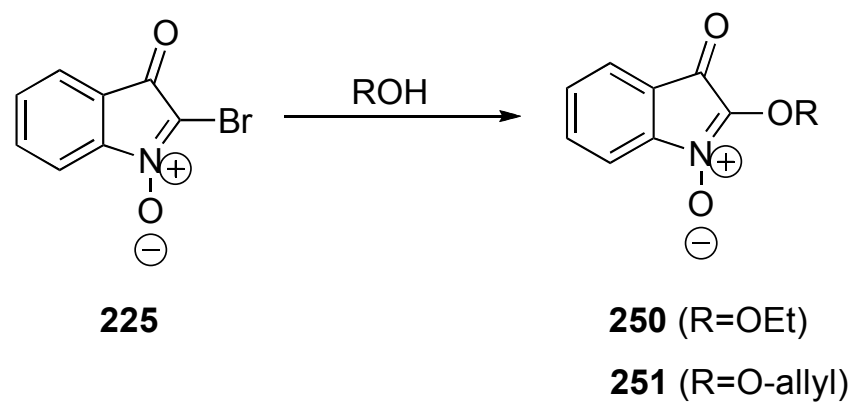

Table 18: Conditions evaluated in the preparation of 2-alkoxyisatogens

\begin{tabular}{|c|c|c|c|c|c|c|}
\hline Entry & ROH & Solvent & Time & Temp. & 2-alkoxyisatogen & isatin \\
\hline 1 & $\mathrm{EtOH}$ & ----- & $24 \mathrm{~h}$ & RT & $90 \%$ & ---- \\
\hline 2 & $\mathrm{HO}_{33 \mathrm{eq}}$ & Methylene chloride & $24 \mathrm{~h}$ & RT & $30 \%$ & --- \\
\hline 3 & $\mathrm{HO}_{2.5 \mathrm{eq}}$ & $\mathrm{THF}, \mathrm{NaH}$ & $3 \mathrm{~h}$ & RT & ---- & $29 \%$ \\
\hline 4 & $\mathrm{HO}_{1 \mathrm{eq}}$ & Chloroform & $40 \mathrm{~min}$ & RT & --- & $38 \%$ \\
\hline 5 & $\mathrm{HO}_{4 \mathrm{eq}}$ & Chloroform & $21 \mathrm{~h}$ & RT & $44 \%{ }^{a}$ & $13 \%$ \\
\hline 6 & $\mathrm{HO}_{5 \mathrm{eq}}$ & Methylene chloride & $16 \mathrm{~h}$ & RT & $38 \%$ & $33 \%$ \\
\hline 7 & $\mathrm{HO}_{2 \mathrm{eq}}$ & Methylene chloride & $26 \mathrm{~h}$ & RT & --- & $30 \%$ \\
\hline 8 & $\mathrm{HO}_{4 \mathrm{eq}}$ & Toluene & $18 \mathrm{~h}$ & RT & $17 \%$ & \\
\hline 9 & $\mathrm{HO}_{4 \mathrm{eq}}$ & Toluene & $2.5 \mathrm{~h}$ & RT & $8 \%$ & $45 \%$ \\
\hline 10 & $\mathrm{HO}_{2 \mathrm{eq}}$ & Toluene & $4 \mathrm{~h}$ & RT & --- & $44 \%$ \\
\hline
\end{tabular}

a Contaminated 


\subsection{Conclusion:}

Although at this stage, the mechanism of these transformations remains unclear, it is certain that palladium has catalyzed the novel transformation of 1-(2-haloethynyl)-2nitrobenzenes into the corresponding isatins. This transformation is perceived to have taken place through the intermediate thermally labile 2-haloisatogens. It was also observed that silver had the unusual ability to catalyze only the formation of 5methoxyisatogen (249) from the TMS-alkyne. The reactions executed on the isolated 2-bromoisatogen (225) have demonstrated that the halogen could be substituted with a good nucleophile besides the fact that the prepared 2-ethoxyisatogen and the 2allyloxyisatogen are very stable. 


\section{Chapter 3}

\section{Carbazolones and 3-Hydroxycarbazoles}

\subsection{Introduction:}

Carbazoles are identified with a structure consisting of a benzene ring fused onto the five-membered ring at 2,3 position of an indole nucleus. The presence of the carbazole moiety in many biologically active compounds has garnered widespread attention in the branch of heterocyclic chemistry. ${ }^{107}$ Most of the alkaloids isolated from plants of Glycosmis, Clausena and Murraya genera were found to contain the carbazole scaffold; the genus Murraya, being the richest source of carbazole alkaloids based on $\mathrm{C}_{13}, \mathrm{C}_{18}$, $\mathrm{C}_{23}$ skeletons. ${ }^{108}$ Different species of Streptomyces, slime moulds and marine sponges have also been the source to several carbazole alkaloids. In addition to the biological sources, abiologic sources such as coal tar, petroleum oil, soil humus and mud were also reported to yield carbazoles. ${ }^{109}$ Treatment of psoriasis with coal tar has been known, although not favored by patients due to aesthetic reasons. Investigations on psoriasis treatment with fractionated components of coal tar have confirmed carbazole to be the active ingredient in coal tar. ${ }^{110}$

Contrary to the notion that the numbering of a heterocyclic compound begins with the heteroatom, carbazole and its derivatives are numbered beginning with the carbon atom closest to the nitrogen atom on the benzene ring, thus assigning the number 9 to the nitrogen atom in the molecule (Figure 10). 


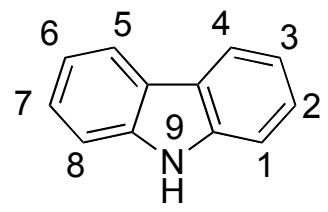

\section{Figure 10: Carbazole}

Carbazolones, the oxo analogues of carbazole and substituted carbazoles are also documented in journals as biologically active compounds. They are frequently encountered as intermediates in the synthetic efforts of several carbazole alkaloids, such as murrayaquinone $A$, murrayanine, koenigine-quinones $A$ and $B$, clausenalene, glycoborine, (+)-aspidospermidine, clausenamine, clausenol and clausenine, clausenal, dimeric murrayafoline $A$, pyrrayaquinones $A$ and $B$, murrayafoline $B$ and murrayaquinone B, hepazolidine, glycozolinol, (-)-gilbertine, and glycozoline. An example of a carbazolone drug used to prevent nausea in patients undergoing chemotherapy and radiation treatments for cancer is ondansetron. ${ }^{111}$

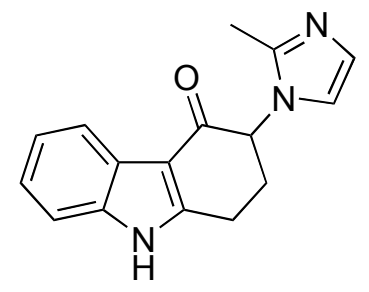

Figure 11: Ondansetron

\subsection{The construction of the carbazole ring}

\section{2 (a) The Fischer indole synthesis:}

A common method to construct the carbazolone ring is the Fischer indole synthesis. Beginning with cyclohexane-1,3-dione (252), the requisite phenyl hydrazone 253 was 
prepared and converted into the carbazolone in presence of a Lewis acid (Scheme 74). ${ }^{112}$ This reaction usually works quite well with 2-and 4-substituted phenylhydrazines, but a mixture of regioisomers is obtained with the 3-substituted analogues. ${ }^{113}$<smiles>NNP(N)(=O)C(PN)C(=O)O</smiles>

252<smiles>O=C1CCC/C(=N/Nc2ccccc2)C1</smiles>

253<smiles>C[AsH2]O[SH2]</smiles><smiles>O=C1CCCc2[nH]c3ccccc3c21</smiles>

$254(51 \%)$

\section{Scheme 74: Fischer indole synthesis for carbazolones}

Another widely accepted preparation of the intermediate phenylhydrazone $\mathbf{2 5 7}$ is the Japp-Klingmann reaction between benzene diazonium salt and 2(hydroxymethylene)-1-cyclohexanones (255). An acid mediated "Fischer indole synthesis" on the phenylhydrazone 257 would form the carbazolone (254) in the ultimate step (Scheme 75).<smiles>O=C1CCCCC1=CO</smiles>

255<smiles>CO[14C](=O)[14CH2][14C](=O)[O-]</smiles>

256<smiles>O=C1CCCCC1=NI</smiles>

257<smiles>O=C1CCCc2[nH]c3ccccc3c21</smiles>

254

Scheme 75: Japp-Klingemann synthesis of the hydrazone 257, the substrate for the Fischer indole synthesis

\section{2 (b) "The heteroannulation" method:}

A group of carbazolone derivatives ${ }^{114}$ have been prepared by Tricia Scott, a former member of our group by utilizing the palladium-catalyzed reductive $\mathrm{N}$-heteroannulation reaction developed in our laboratory. The synthetic strategy comprised of treating 2-(2- 
nitrophenyl)-2-cycloalkenones 257 and 3-(2-nitrophenyl)-2-cycloalkenones $\mathbf{2 6 1}$ to the annulation conditions of the palladium catalyst, ligands and carbon monoxide to afford the respective carbazoles in good yields. The synthesis of the cyclization precursors 257 and 261 was achieved by adopting the "Stille reaction" conditions reported by Johnson et.al. to couple 2-iodocycloalkenones $\mathbf{2 6 0}$ or 3-iodocycloalkenones $\mathbf{2 5 6}$ with aryl stannanes $\mathbf{2 5 5} .^{115}$

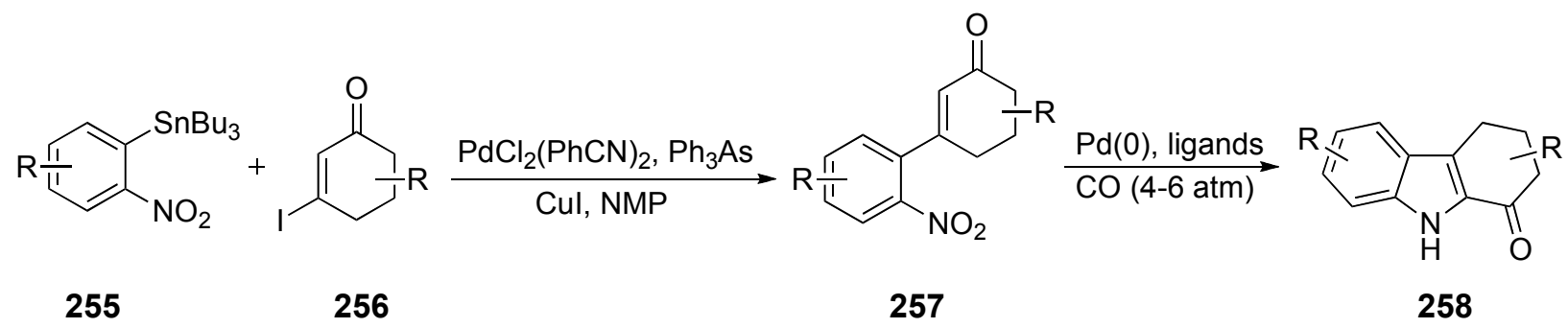

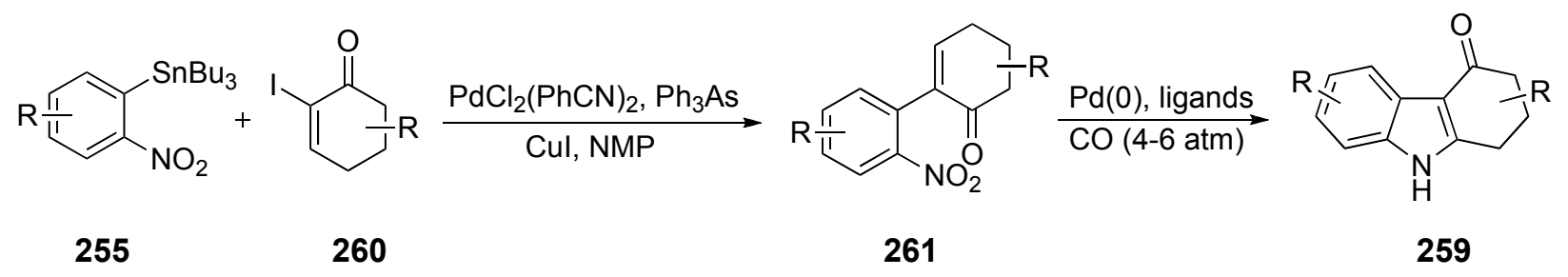

Scheme 76: The strategy to synthesize carbazolones

\subsection{Results and Discussion:}

Among the numerous carbazolones prepared by Tricia Scott, were the carbazolones 258(a-d), synthesized in excellent yields by the palladium catalyzed reductive heteroannulation reaction (Table 19). These four carbazolones could also be prepared

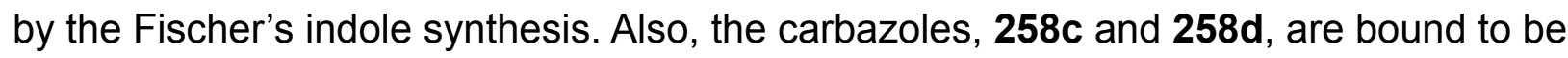
formed as an isomeric mixture, had they been synthesized by Fisher's method from their common precursor hydrazone 262. 
Table 19: Carbazolones synthesized via palladium-catalyzed reductive $\mathrm{N}$-heteroannulation reaction

Entry Stille Coupled Product

A report published in the year 1998 by Chowdhury and his group referred to the formation of 2-methoxy-6-methyl-8-oxo-5,6,7,8-tetrahydrocarbazole (258c) from a sequential Japp-Klingemann reaction and Fischer indole synthesis as a colourless solid in $65 \%$ yield. ${ }^{116}$ Another article by the same research group, published a few years 
earlier in 1992, has quoted that 4-methoxy-6-methyl-8-oxo-5,6,7,8-tetrahydrocarbazole (258d) has formed in a yield of $50 \%$ from the same reaction, with no reported yield of isomer 258c. ${ }^{113 a}$ Puzzled by these ambiguous results, the reaction was repeated by us under the same reported conditions. ${ }^{117}$ The partner for the Japp-Klingemann reaction, 2-(hydroxymethylene)-5-methylcyclohexanone $(\mathbf{2 6 4})^{118}$, was prepared from 3methylcyclohexanone (263) and reacted with $m$-methoxybenzene diazonium chloride (265) under basic conditions. ${ }^{118}$ The hydrazone 262 thus obtained, was treated with

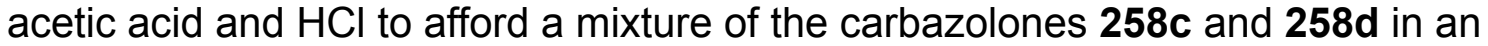
approximate ratio of 7:1 (Scheme 77).<smiles>CC1CCCC(=O)C1</smiles>

263

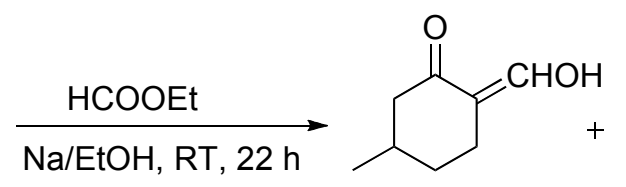

$264(51 \%)$<smiles>COc1cccc(NN=C2CCC(C)CC2=O)c1</smiles>

265

$262(40 \%)$<smiles>COc1cccc2[nH]c3c(c12)CC(C)CC3=O</smiles>

258d $(7 \%)$<smiles>COc1ccc2c3c([nH]c2c1)C(=O)CC(C)C3</smiles>

$258 \mathrm{c}(49 \%)$

Scheme 77: The two isomeric carbazolones, $258 \mathrm{c}$ and $258 \mathrm{~d}$, obtained via the Fischer indole synthesis

In the year 2001, another group of researchers led by A. Chakravorty, a former member of the Chowdhury group, reported a Fischer indole synthesis on the 4methylcyclohexanehydrazone derivative $\mathbf{2 6 8}$, which was prepared in situ from a condensation between $m$-methoxyphenylhydrazine (267) and 4-methylcyclohexanone (266). ${ }^{119}$ The outcome of this reaction was the formation of two isomeric 
tetrahydrocarbazoles $\mathbf{2 6 9 c}$ and $\mathbf{2 6 9 d}$ in a ratio of 9:1 (Scheme 78 ). These results are comparable to the results of the reaction executed by us as shown in Scheme 77 .

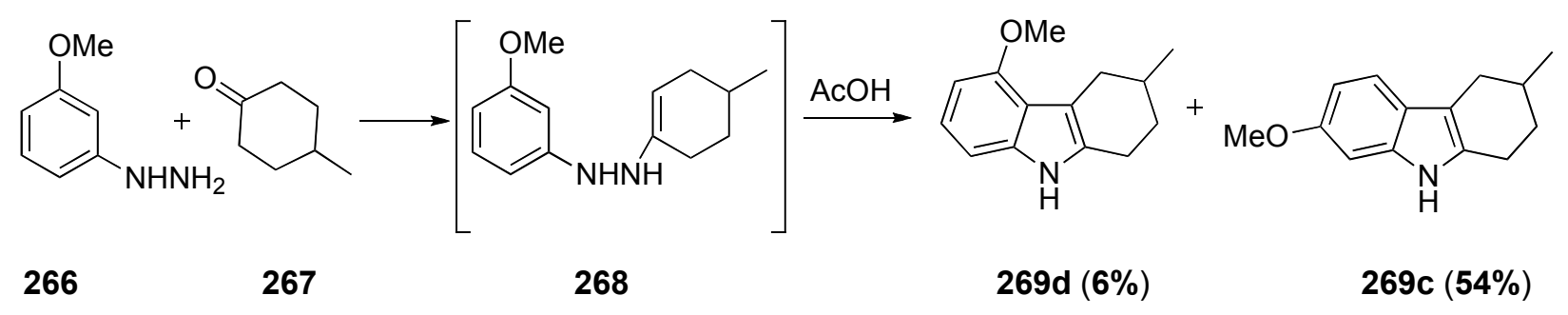

Scheme 78: The two isomeric tetrahydocarbazoles as reported by the Chakravorty group

To further substantiate our results, a Wolff-Kishner-Huang-Minlon reduction of 258c gave 269c having ${ }^{1} \mathrm{H}-\mathrm{NMR}$ chemical shifts, identical to those reported by the Chakravorty group. ${ }^{119}$

While the main focus of our group has been to construct the carbazolone ring from 3(2-nitrophenyl)-2-cyclohexeneone derivatives via the heteroannulation reaction, the concept of initiating an internal nucleophillic addition on the nitro group to form a hydroxycarbazole was a possible consideration. Moskalev and Makosza have reported a reaction between the nitroarene $\mathbf{2 7 0}$ and cyclohexanone (271) in the presence of a base that has resulted in the formation of $o$-hydroxydiarylamines $\mathbf{2 7 2}$. The formation of 272 was apparent from a direct nucleophillic addition of the cyclohexanone enolate on the nitro group. As a result of the problem encountered in the isolation and purification, 272 was ultimately converted into the stable o-methoxy derivative $\mathbf{2 7 3}$ by the authors (Scheme 79). ${ }^{120}$ 


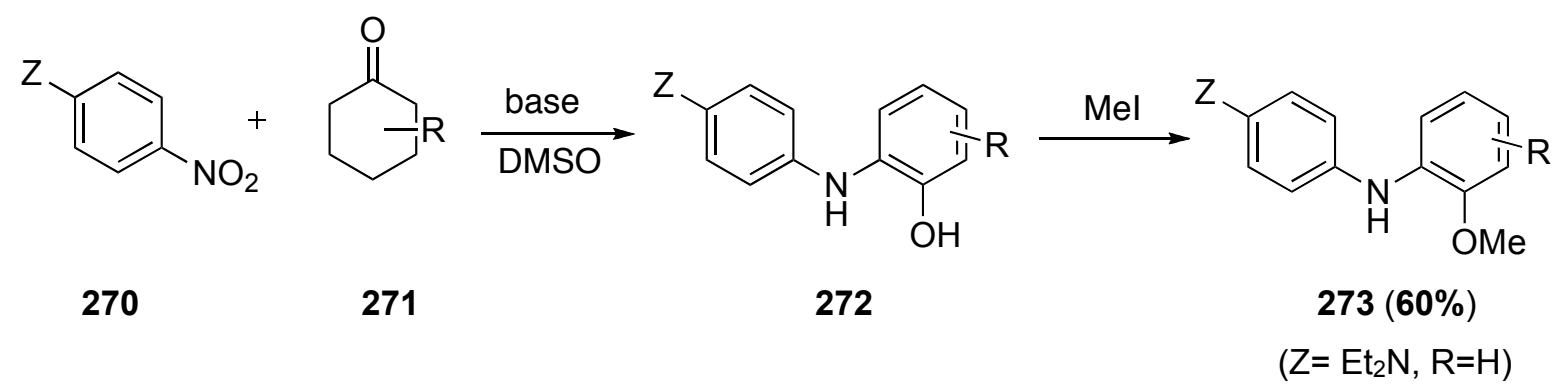

Scheme 79: Synthesis of o-hydroxydiarylamines by Makosza et. al

Another reaction that demonstrates an intermolecular carbanion attack on the nitro group has also been reported by the same research group, which observed that acenaphthenone (274) gave an inseparable mixture of 275 and 276 when reacted with $\mathrm{NaOH}$. A reduction of this mixture led to compound $\mathbf{2 7 5}$ exclusively. As a final part in their study, the mixture was treated with methyl iodide to isolate these products as their $\mathrm{N}$-methoxy and $\mathrm{N}$-methyl analogues 277 and 278 (Scheme 80). ${ }^{121}$ 


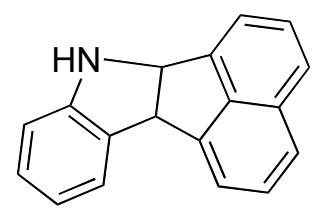

275

Zn, AcOH

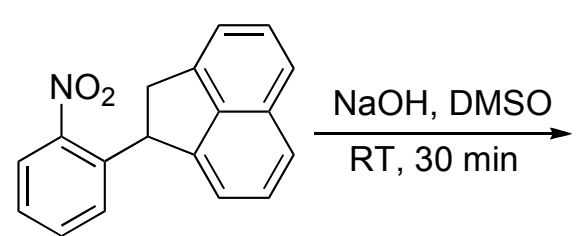

274

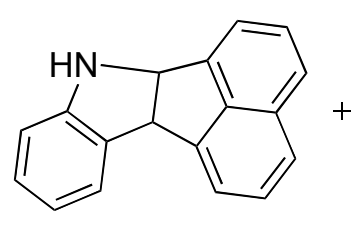

275<smiles>ON1c2ccccc2C2c3cccc4cccc(c34)C21</smiles>

276

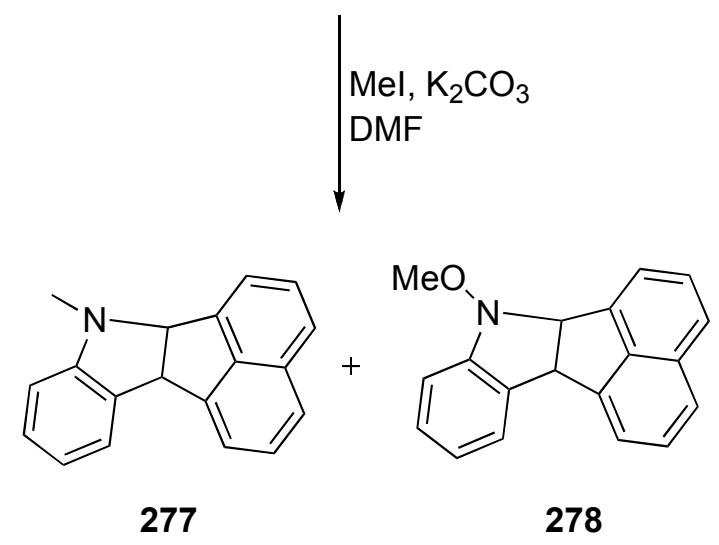

\section{Scheme 80: The "Makosza" group's experiments on acenathenone}

With these reactions in mind, it was speculated that a similar reaction of the compound $\mathbf{2 5 7 b}$ with a base would lead to a carbazole derivative. Thus, a test reaction was performed on $\mathbf{2 5 7 b}$ at $70{ }^{\circ} \mathrm{C}$ with $\mathrm{DBU}$ as the base and DMF as the solvent. The reaction afforded the 1-methyl-3-hydroxycarbazole (279), with no trace of the N-hydroxy carbazole derivative. 


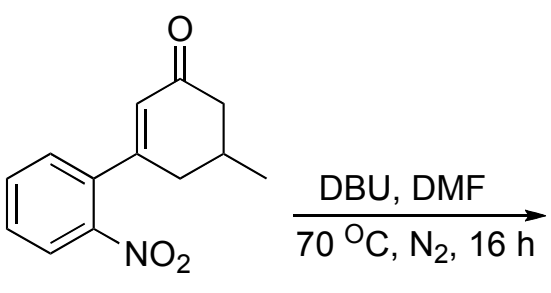

257b

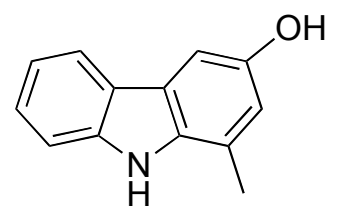

$279(28 \%)$

\section{Scheme 81: The formation of 1-methyl-3-hydroxycarbazole (279)}

The reaction was also examined on 3-(2-nitrophenyl)-2-cyclohexeneone (257e), which afforded 3-hydroxycarbazole (283) in 20\% yield under identical conditions. A number of conditions were tried in an effort to maximize the yield (Table 20), but the yield could not be increased beyond $23 \%$. The reaction could be accounted with an initial nucleophillic addition of the carbanion 281a on the nitrogen atom of the nitro group. However, such a

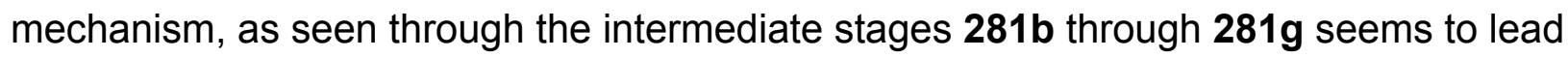
to a 3,9-dihydroxycarbazole (282) as opposed to the 3-hydroxycarbazole (283) (Scheme 82). A similar type of transformation was seen on acenaphthenone, ${ }^{121}$ depicted in Scheme 80. The inseparable mixture of $\mathbf{2 7 5}$ and $\mathbf{2 7 6}$ gave the indole $\mathbf{2 7 5}$, when reduced with zinc and acetic acid. Comparing our results with those reported by the Makosza group, it is likely to assume that the N-hydroxycarbazole (282) is very unstable and is quickly transformed (reduced) into the carbazole 283. Also, the failure to obtain any $\mathrm{N}$-hydroxymethylcarbazole upon the addition of methyl iodide (Entries 8 and 10, Table 20) substantiates the assumption that the $\mathrm{N}$-hydroxycarbazole is too shortlived to be trapped as its methoxyderivative. 
<smiles>O=C1C=C(c2ccccc2[N+](=O)[O-])CCC1</smiles>

$257 e$<smiles>Oc1ccc2[nH]c3ccccc3c2c1</smiles>

283

\begin{tabular}{|c|c|c|c|c|c|c|c|}
\hline S. No. & Base & Eq. & Solvent & Time & Temp. & 283 & $\begin{array}{c}\text { SM } \\
\text { (257e)rec } \\
\text { overed }\end{array}$ \\
\hline 1 & DBU & 2 & THF & $15 \mathrm{hrs}$ & $70^{\circ} \mathrm{C}$ & $20 \%$ & -- \\
\hline 2 & DBU & 2 & THF & $6 \mathrm{hrs}$ & $70^{\circ} \mathrm{C}$ & $17 \%$ & $44 \%$ \\
\hline 3 & DBU & 2 & THF & $19 \mathrm{hrs}$ & $70^{\circ} \mathrm{C}$ to $90^{\circ} \mathrm{C}$ & $17 \%$ & $22 \%$ \\
\hline 4 & $\mathrm{KOH}$ & 1.3 & DMSO & $30 \mathrm{~min}$ & reflux & -- & -- \\
\hline 5 & DBU & 1 & THF & $21 \mathrm{hrs}$ & $70^{\circ} \mathrm{C}$ & $24 \%$ & -- \\
\hline 6 & DBU & 1 & $\mathrm{CH}_{3} \mathrm{CN}$ & $15 \mathrm{hrs}$ & $70^{\circ} \mathrm{C}$ & -- & $35 \%$ \\
\hline 7 & DBU & 2 & DMF & $2 \mathrm{hrs}$ & $100^{\circ} \mathrm{C}$ & $24 \%$ & -- \\
\hline $8^{*}$ & DBU & 1.7 & DMF & $2 \mathrm{hrs}$ & $100^{\circ} \mathrm{C}$ & $21 \%$ & -- \\
\hline $9^{* *}$ & DBU & 1 & DMF & 4 days & RT & $14 \%$ & -- \\
\hline $10^{* * *}$ & DBU & 1 & DMF & 3.5 days & RT & -- & -- \\
\hline
\end{tabular}

* Mel added after $2 \mathrm{~h}$, let it go for another $15 \mathrm{~min}$

** another product, tentatively assigned as 4,5-dihydroxycarbazole through NMR isolated in $10 \%$, not detected through HRMS

*** Mel was added after $36 \mathrm{~h}$, unable to characterize the products 


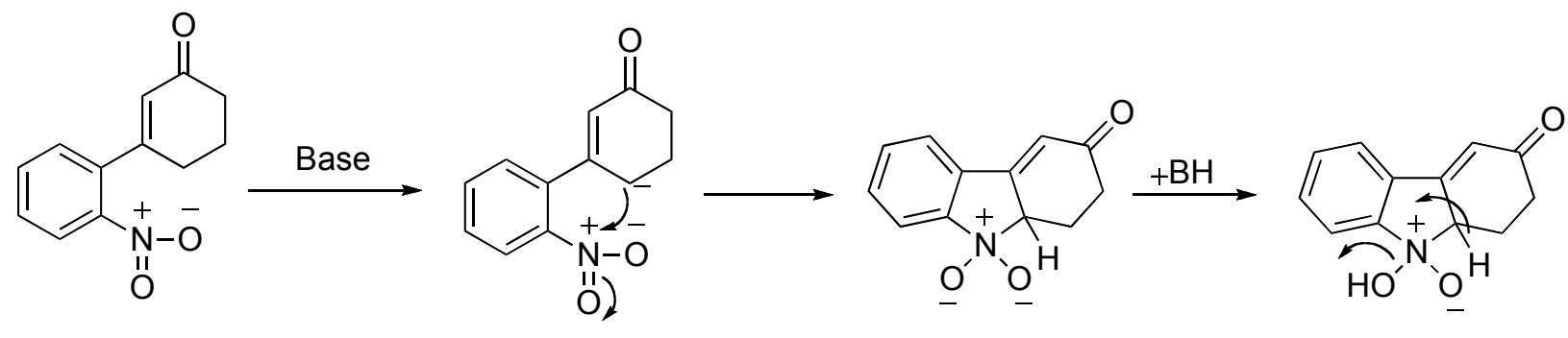

257e

281a

281b

281c

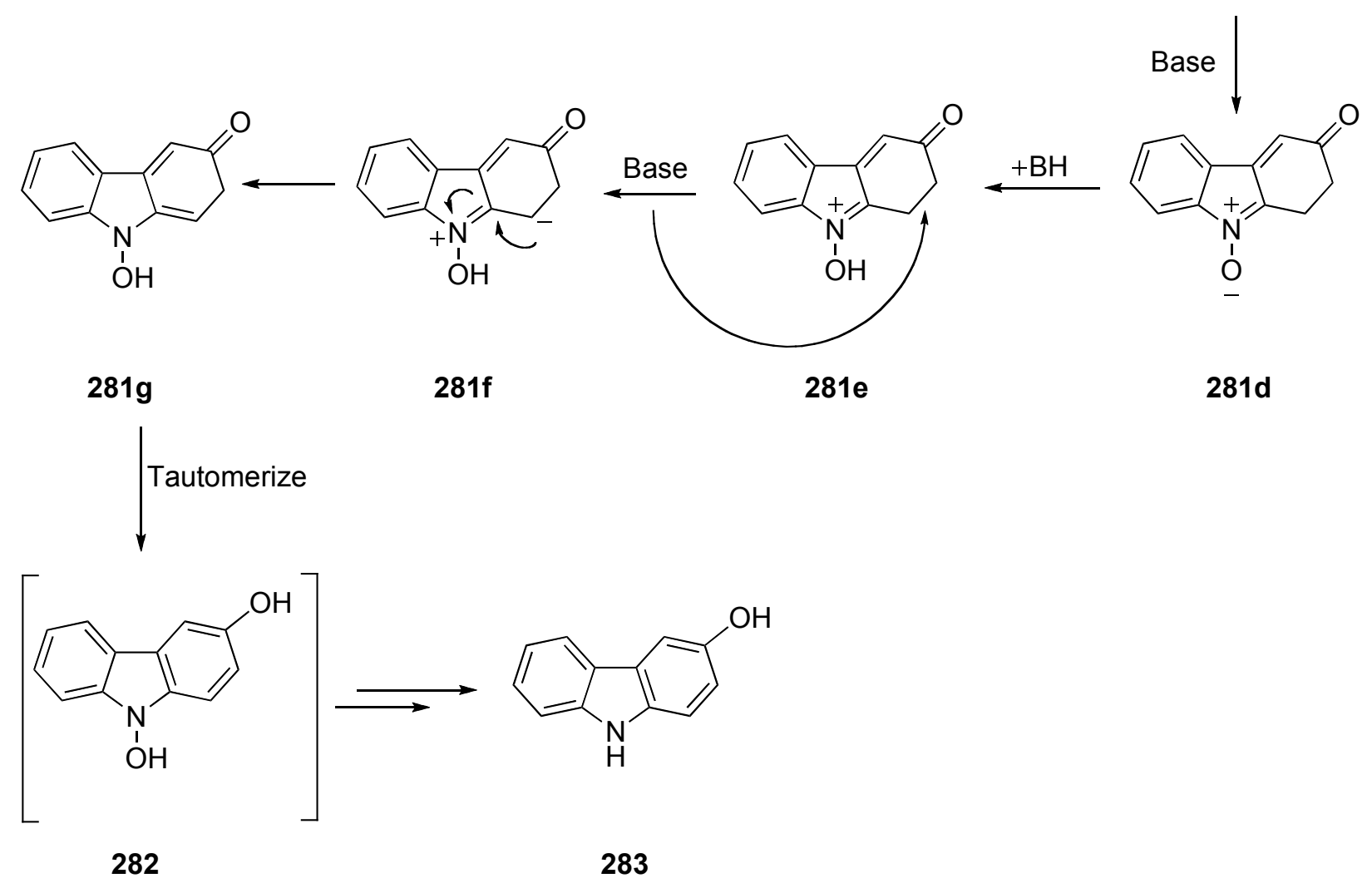

Scheme 82: The plausible mechanistic pathway to the 3-hydroxycarbazole (283)

\subsection{Conclusion:}

In summary, a comparative study on the syntheses of carbazolones via the palladiumcatalyzed reductive N-heteroannulation methodology and Fischer's synthesis was executed. It was evident from the results that the Fischer indole synthesis affords the desired products in a lower yield with an additional disadvantage of forming two regioisomers from the precursor $m$-methoxyphenylhydrazone derivative 262. Further, it 
was also demonstrated that a base mediated reaction on 3-(2-nitrophenyl)-2-

cyclohexenone (257e) forms the 3-hydroxycarbazole (283). Although the yield of the 3hydroxycarbazole was low, it undoubtedly provides an insight into the mechanism and the stability of the predicted 3,9-dihydroxycarbazole (282). 


\section{Chapter 4:}

\section{Attempted Synthesis of the Model Indole Fragment of Nosiheptide}

\subsection{Introduction:}

Nosiheptide, a sulphur-containing polypeptide antibiotic was isolated from Streptomyces actuosus 40037 (NRRL 2954) in the early 1960's by a group of French researchers. ${ }^{122,123}$ It inhibits protein synthesis in gram positive bacteria by binding to the ribosomal unit in vitro. Found to be non-toxic, it is frequently employed as a food additive to promote growth and weight gain in pigs and chicken. The structure of nosiheptide, determined by a series of chemical degradation processes, X-ray crystallographic and NMR studies indicated the presence of two macrocyclic regions, incorporating five thiazoles, one pyridine and one indole rings. ${ }^{124}$

To date, there have been no routes to the total synthesis of this antibiotic. However, approaches to the fragments have been reported. ${ }^{125}$ From a retro-synthetic perspective, nosiheptide is divided into two hemispheres, each comprising of three fragments: dehydroalanine and fragments A (2,3,5,6-tetrasubstituted pyridine), B (threonine), C (threonine-cysteine derived propenylthiazole), D (modified glutamate) and E (2,3,4trisubstituted indole). 


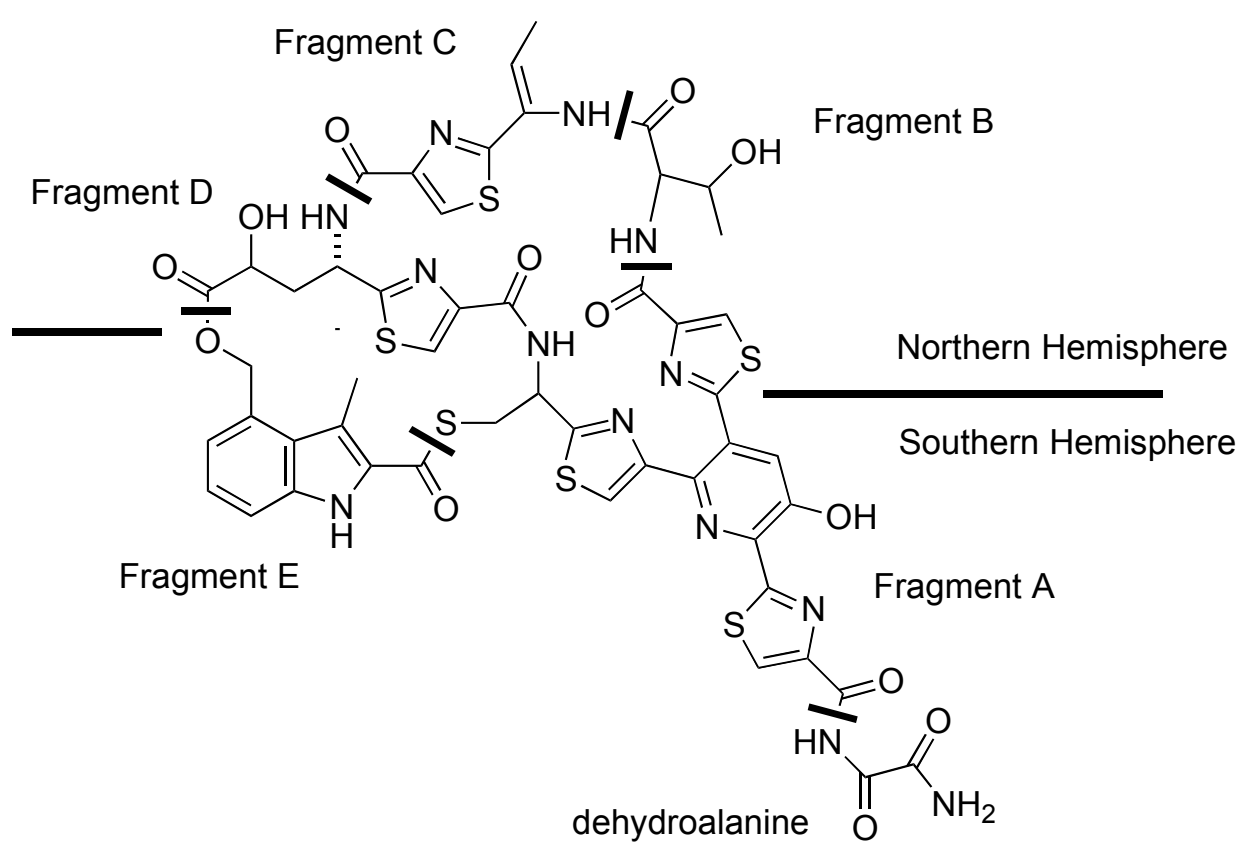

Figure 12: Nosiheptide

\subsection{The "Moody" group's syntheses of the indole fragment: ${ }^{125}$}

Synthetic routes to the various fragments of nosiheptide, including that of a potential precursor to the B-C-D fragment have been described. Many of these were synthesized with protecting groups, which appear to prevent their use in the total synthetic sequences. Two syntheses of the trisubstituted indole fragment have been reported by Christopher Moody's group. Their first synthesis of the indole fragment involved the application of the Hemmetsberger indole synthesis, which is noted as an efficient synthesis to prepare indole-2-carboxylate derivatives. The required substrate for this reaction, the $\alpha$-azidocinnamate derivative $\mathbf{2 8 6 a}$ was synthesized through a base catalysed condensation between o-methylbenzaldehyde $285 \mathrm{a}$ and methyl azidoacetate. Thermal decomposition of $\mathbf{2 8 6 a}$ gave the indole $\mathbf{2 8 4}$, which was subsequently formylated at the 3-position after a series of reactions to yield the intermediate $\mathbf{2 8 9}$ in 
good yield. The synthesis of the indole 284 was also carried out from a 2-

tetrahydropyranoyloxymethyl benzaldehyde (285b), but the yields were lower compared to the synthesis from o-tolualdehyde (285a). Additionally, the indole $\mathbf{2 8 4}$ was also synthesized through Sundberg's phosphite mediated deoxygenative cyclisation of the 2nitrocinnamate derivative $\mathbf{2 8 8}$, which was prepared from 2-bromo-3-nitrotoluene (287) and methylacrylate via the palladium catalyzed Heck reaction (Scheme 83). The formyl group at the 3-position in the intermediate indole $\mathbf{2 8 9}$ served as an ideal functional group that was easily transformed into the desired methyl group seen in the indole fragment of nosiheptide molecule.<smiles>[R]Cc1ccccc1/C=C(\N)C(=O)OC</smiles>

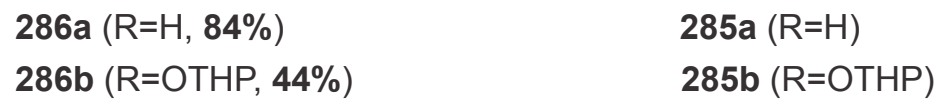

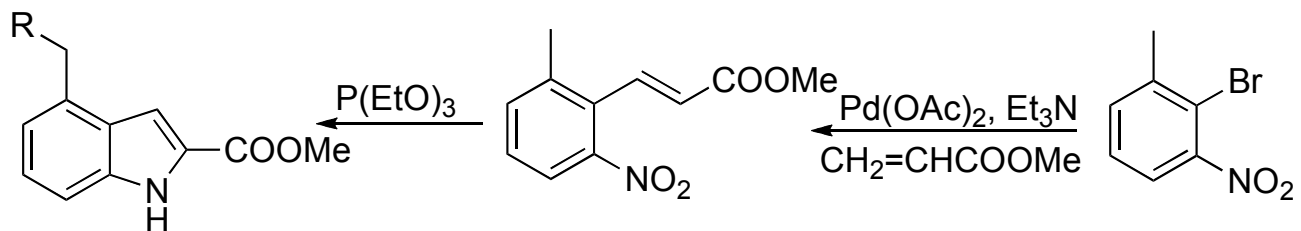

$284(\mathrm{R}=\mathrm{H}, 89 \%)$

$288(74 \%)$

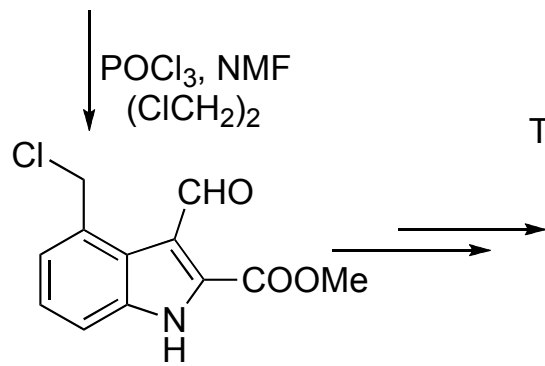

$289(78 \%)$
TBSO<smiles>CC(=O)c1[nH]c2cccc(CO)c2c1C</smiles>

$290(63 \%)$

Scheme 83: Synthesis of the indole fragment by the Moody group 
A shorter approach to the indole fragment was also developed by the Moody group using the Fischer indole synthesis as the key step (Scheme 84). The requisite hydrazine 293 was synthesized from the commercially available 3-amino-4-chloro-benzoic acid 291 in three steps comprising of a diazotization, followed by reduction and an immediate condensation of the intermediate arylhydrazine 292, with methyl-2oxobutanoate. The polyphosphoric acid assisted Fischer cyclization of $\mathbf{2 9 3}$ gave the indole 294, which was subjected to hydrogenolysis to remove the masking chloro substituent. Reduction of the carboxylic acid $\mathbf{2 9 5}$ was then carefully executed with borane dimethylsulfide complex, and the resulting alcohol 296 was ultimately protected as the TBS ether to yield the model indole moiety 290 .<smiles>Nc1cc(C(=O)O)ccc1Cl</smiles>

291<smiles>CCOC(=O)CC(C)=O</smiles>

292<smiles>COC(=O)/C(C/C=C(\C)[PH2+]C1CC1)=N/Nc1cc(C(=O)O)ccc1Cl</smiles>

$293(100 \%)$<smiles>CC(=O)c1[nH]c2c(Cl)ccc(C(=O)O)c2c1C</smiles>

$294(87 \%)$<smiles>COC(=O)c1[nH]c2cccc(COC(C)(C)C)c2c1C</smiles>

$290(41 \%)$

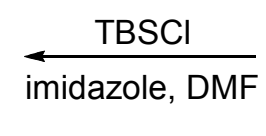

296 (78\%)<smiles>COC(=O)c1[nH]c2cccc(CO)c2c1C</smiles>

$\frac{\mathrm{BH}_{3}-\mathrm{DMS}}{\mathrm{THF}}$<smiles>CC(=O)c1[nH]c2cccc(C(=O)O)c2c1C</smiles>

295 (85\%)

Scheme 84: Synthesis of the indole fragment by the Fischer indole synthesis

\subsection{Results and discussion:}

In the course of extending the viability of the conditions for the "reductive Nheteroannulation', a group of 2,3-substituted indoles with an electron withdrawing group, 
present at the 3-position were synthesized. ${ }^{126}$ Also, a survey of "indole literature" reveals the preparation of a plethora of indole-3-carboxylates synthesized by the Hemmetsberger-Knittel synthesis. With the requirement of an ester and an alkyl group at the 2- and 3-positions, respectively, on the indole fragment of nosiheptide, and the results of 2,3-substituted indoles in hand, the synthesis of the indole fragment appeared feasible via the palladium-catalyzed annulation reaction.

Retrosynthetically, the construction of the indole fragment could be seen as a palladium-catalyzed reductive N-heteroannulation of the styrene 298. The styrene, 298 could be envisioned as the coupling product from the stannane $\mathbf{3 0 0}$, a previously reported compound synthesized from methyl-2-butynoate 301 and the aryl halide 299 .

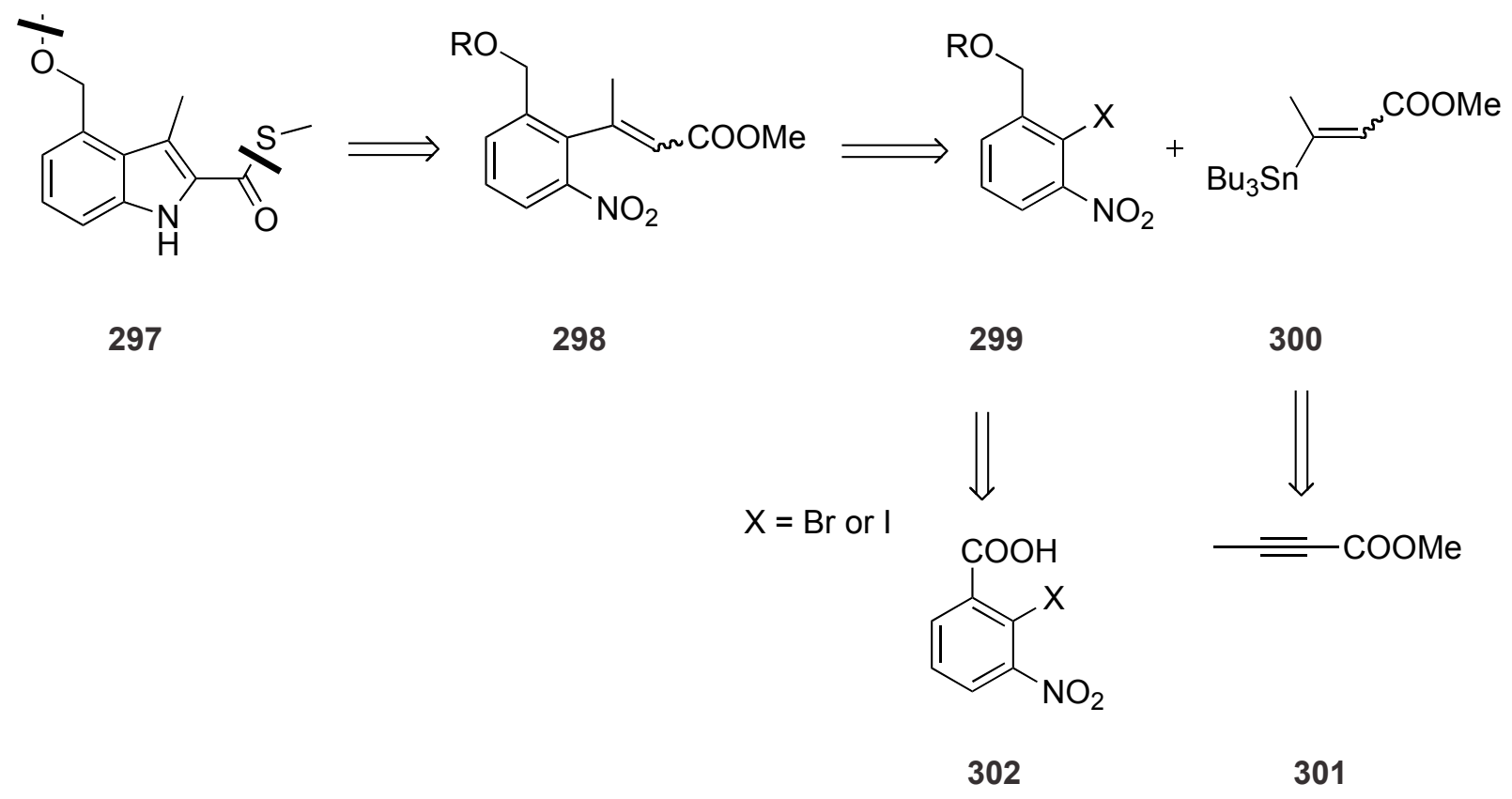

\section{Scheme 85: Retrosynthesis of the indole fragment of nosiheptide}

The synthesis of the aryl halide 299 required the commercially available 2-bromo-3nitrobenzoic acid (302a) to begin with, but owing to its high price, it was synthesized 
from a relatively less expensive 3-nitrophthalic acid (303) in two steps following a published procedure. ${ }^{127}$ The first step involved the conversion of 3-nitrophthalic acid into anhydro-2-hydroxymercuri-3-nitrobenzoic acid (304) using mercuric acetate, sodium hydroxide, and acetic acid. Subsequent bromination ${ }^{127}$ of $\mathbf{3 0 4}$ in the second step afforded the 2-bromo-3-nitrobenzoic acid (302a) as a colorless solid.

Reduction of 2-bromo-3-nitrobenzoic acid (305) with $\mathrm{BH}_{3}$.DMS complex gave the 2bromo-3-nitrobenzylalcohol $(305)^{126}$ that was brominated using carbon tetrabromide and triphenylphosphine to afford 2-bromo-3-nitrobenzyl bromide $(\mathbf{3 0 6})^{125}$ in a moderate yield. The allyloxy ether $\mathbf{3 0 7}$ was then prepared from $\mathbf{3 0 6}$ by Williamson's ether synthesis (Scheme 86). ${ }^{126}$

The corresponding iodo-analogue (309) of compound 306 was also prepared using the same reaction sequence. It was then easily converted into the methoxy ether $299 \mathrm{~b}$ in a good yield.<smiles>CC(=O)OC(=O)O[Hg](=O)[O-]</smiles>

303<smiles>O=C1O[Hg]c2c1cccc2[N+](=O)[O-]</smiles>

304

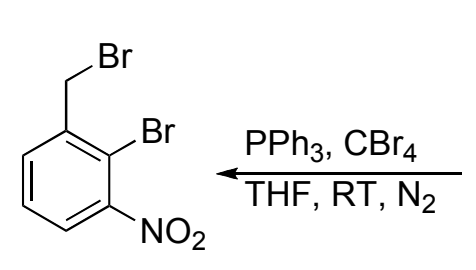<smiles>O=[N+]([O-])O</smiles><smiles>O=C(O)c1cccc([N+](=O)[O-])c1Br</smiles>

$302 a(38 \%)$

$\mathrm{BH}_{3}$.DMS THF, 45 min, reflux<smiles>C=CCOCc1cccc([N+](=O)[O-])c1Br</smiles>
307 (56\%) $306(69 \%)$<smiles>O=[N+]([O-])c1cccc(CO)c1Br</smiles>

305 (99\%) 

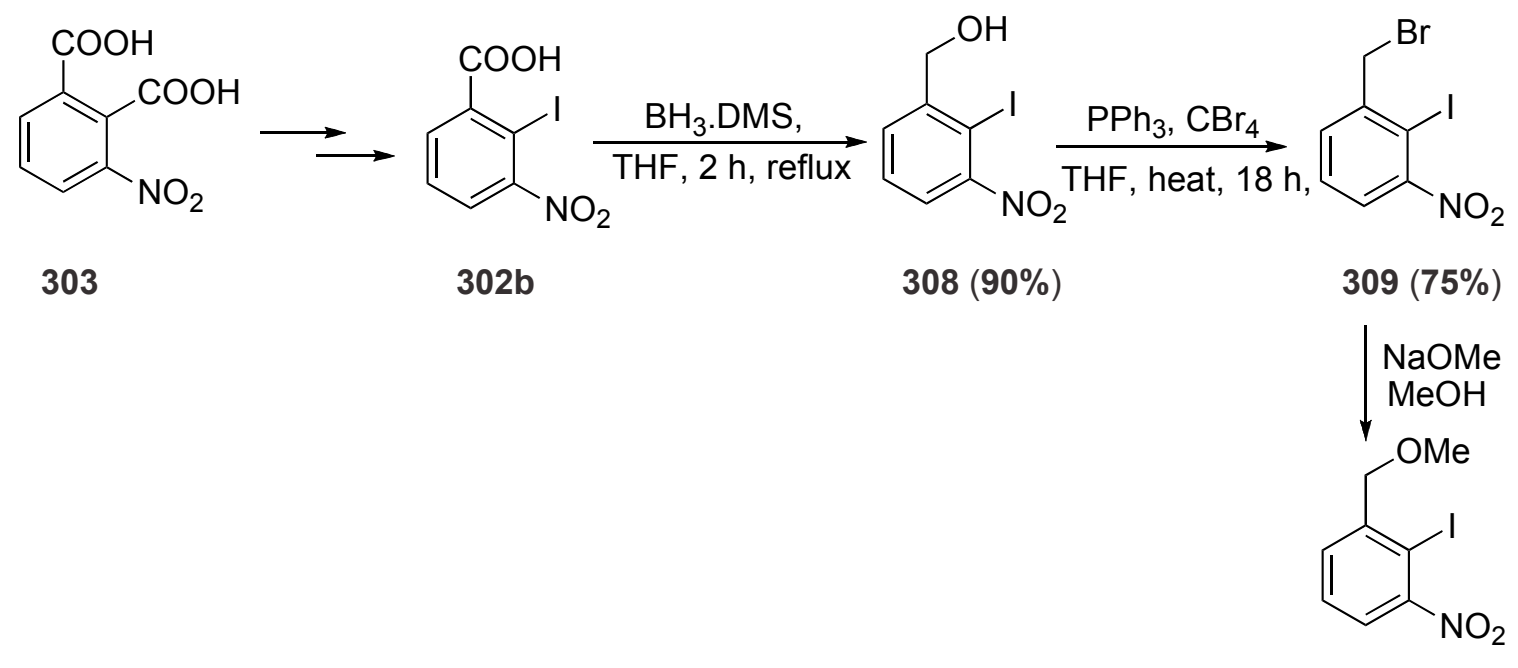

$299 \mathrm{~b}(76 \%)$

Scheme 86: Syntheses of the 2-halo-3-nitrobenzyl ethers, 307 and 299b

The coupling partner for $\mathbf{2 9 9 b}$, the stannane $\mathbf{3 0 0}$ was prepared as a mixture of the $E$ and Z-isomers from methyl-2-butynoate (301) by a lithium diisopropylamide mediated reaction with tributyltin hydride in the presence of solid copper bromide-dimethyl sulfide complex (Scheme 87). ${ }^{128}$

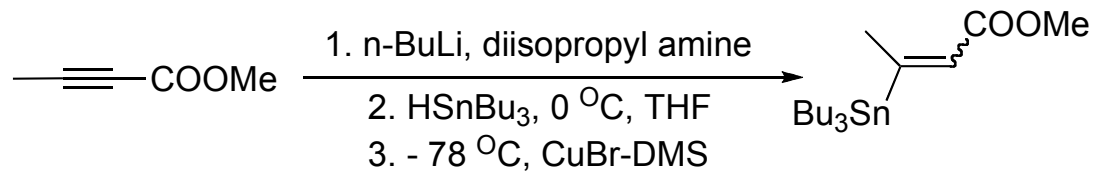

301

$300(51 \%)$

\section{Scheme 87: Preparation of the stannane 300}

A Stille coupling between the prepared stannane 300 and the methoxy ether $299 \mathrm{~b}$ failed to yield the required styrene derivative $298 \mathrm{a}$. The two reactants, $299 \mathrm{~b}$ and $\mathbf{3 0 0}$ were recovered unchanged. (Scheme 88). A test reaction between 2-iodo-3-nitromethylbenzoate (310) and the stannane $\mathbf{3 0 0}$ also failed to yield the corresponding coupled product 311; a total recovery of the two reactants was observed in this case. 
<smiles>COCc1cccc([N+](=O)[O-])c1I</smiles>

299b<smiles>COC(=O)OC</smiles><smiles>CCCC[SnH3+]C(C)=CC(=O)OC</smiles>

310

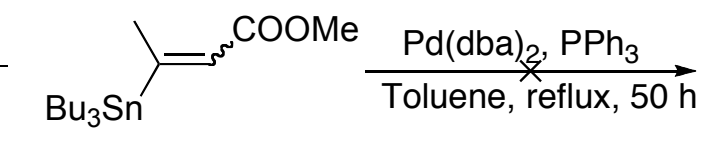

300<smiles>COCc1cccc([N+](=O)[O-])c1/C(C)=C/C(C)=O</smiles>

$298 a$<smiles>COC(=O)C=C(C)c1c(C(C)=O)cccc1[N+](=O)[O-]</smiles>

311

Scheme 88: Attempted Stille coupling on 2-iodo-3-nitrobenzylmethylether (299b) and 2-iodo-3-nitromethylbenzoate (310)

With the recovery of the two reactants, the idea of executing the Stille-coupling on the aryl stannane 312 and methyl-3-iodo-2(Z)-butenoate (313) was considered. Following the procedure of Lu and his coworkers, the regiospecific hydroiodination was executed on methyl-2-butynoate (301) to afford methyl-3-iodo-2(Z)-butenoate (313) (Scheme 89). ${ }^{129}$

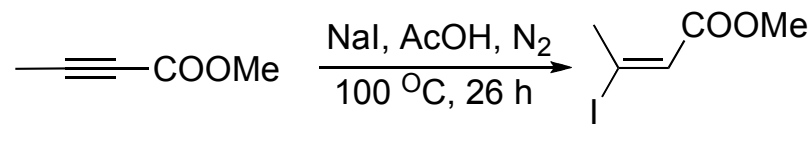

301

$313(40 \%)$

\section{Scheme 89: Preparation of methyl-3-iodo-2(Z)-butenoate (313)}

A palladium-catalyzed reaction between the methoxy ether $299 \mathrm{~b}$ and hexamethyl distannane gave the desired stannane $\mathbf{3 1 2}$, but in a low yield. The starting material was recovered along with a-methoxy-2-methyl-3-nitrotoluene (314). A better yield was obtained when the reaction was carried out at $90^{\circ} \mathrm{C}$ (Table 21, Entry 3), but 314 was also obtained as a second product. These results are shown below (Table 21). 
<smiles>COCc1cccc([N+](=O)[O-])c1I</smiles>

299b
$+(\mathrm{Me})_{6} \mathrm{Sn}_{2} \underset{\text { Toluene, Reflux }}{\stackrel{\mathrm{PdCl}_{2}, \mathrm{PPh}_{3}}{\longrightarrow}}$<smiles>COCc1cccc([N+](=O)[O-])c1SC</smiles>

312

Scheme 90: Preparation of the stannane 312

Table 21: Conditions evaluated in the preparation of stannane 312

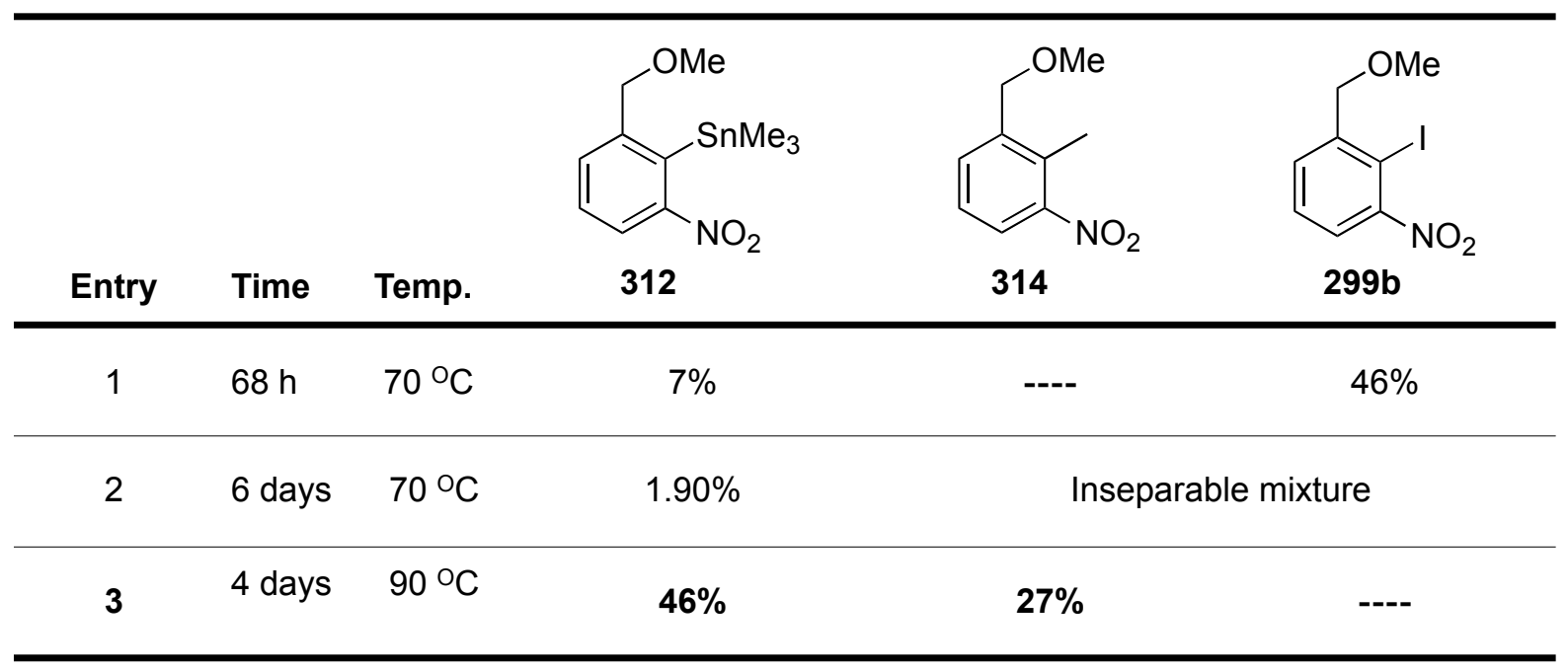

The Stille coupling conditions, when attempted on the stannane 312 and methyl-3iodo-2(Z)-butenoate (313), showed no formation of the desired styrene derivative 298a; however, a-methoxy-3-nitrotoluene (315) $)^{130}$ was obtained in a yield of $68 \%$ (Scheme 91).<smiles>COCc1cccc([N+](=O)[O-])c1SC</smiles>

312<smiles>COC(=O)C=C(C)I</smiles>

313

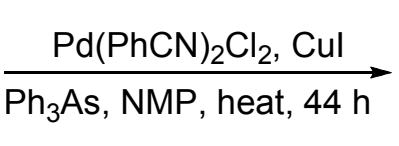
$\mathrm{Ph}_{3} \mathrm{As}, \mathrm{NMP}$, heat, $44 \mathrm{~h}$<smiles>COCc1cccc([N+](=O)[O-])c1/C(C)=C/C(C)=O</smiles>

298a $(0 \%)$<smiles>COCc1cccc([N+](=O)[O-])c1</smiles>

$315(68 \%)$

Scheme 91: The attempted Stille coupling between the aryl stannane (312) and 3-iodo-methyl-2-butenoate (313) 
The Heck reaction ${ }^{131}$ offers an alternative to prepare aryl substituted alkenes from an aryl halide and an alkene. Commercially available methyl-2-butenoate (316) was reacted with 299b under the 'Heck reaction conditions' of palladium acetate (10 mol \%), triphenylphosphine $(40 \mathrm{~mol} \%)$ and triethylamine at $70^{\circ} \mathrm{C}$ for 4 days. The reaction was unsuccessful, marked by the recovery of $299 \mathrm{~b}$ along with a-methoxy-3-nitrotoluene (315), as an inseparable mixture (Scheme 92).

Replacing the triphenylphosphine with triphenyl arsine offered no improvement; a mixture of compounds $299 \mathrm{~b}$ and $\mathbf{3 1 5}$ was formed as in the earlier reaction.

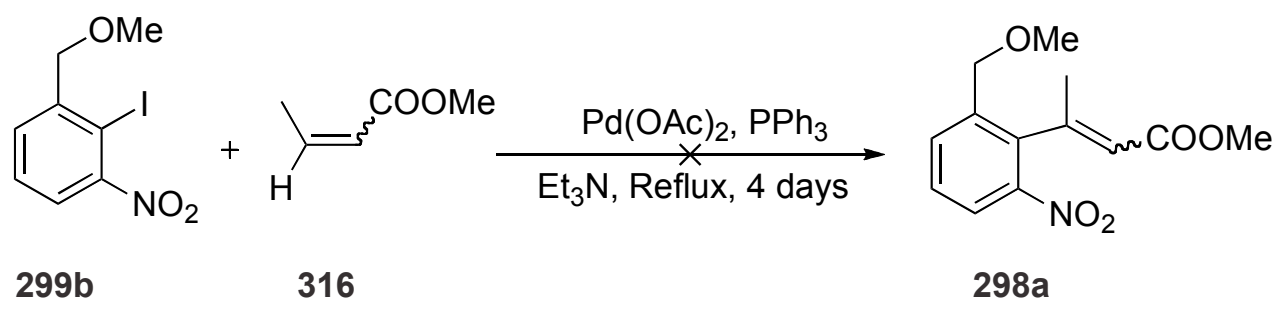

\section{Scheme 92: Attempted Heck reaction between methyl-2-butenoate (316) and 2-iodo-3-nitrobenzylmethylether (299b)}

Following the failures to generate the key o-nitrostyrene precursor $298 \mathrm{a}$, a second retrosynthesis of the indole fragment was designed, wherein the idea was to construct the 3,4-fused indole $\mathbf{3 1 7}$, followed by the cleavage of the ether with a lewis acid. A group of 3,4-fused indoles has been synthesized earlier in our laboratory. ${ }^{132}$ Based upon this result, it was proposed to transform the allyl ether $\mathbf{3 0 7}$ into the $\alpha, \beta$-unsaturated ester $\mathbf{3 1 8} \mathbf{a} / \mathbf{3 1 8 b}$ through ozonolysis and a subsequent Wittig reaction with $\mathbf{3 2 0}$. The possibility of preparing the $\alpha, \beta$-unsaturated ester $318 \mathrm{a} / 318 \mathrm{~b}$ from 2-halo-3nitrobenzylalcohol (305/308) and the commercially available $\gamma$-bromo-methylcrotonoate (319) was another option (Scheme 93). 


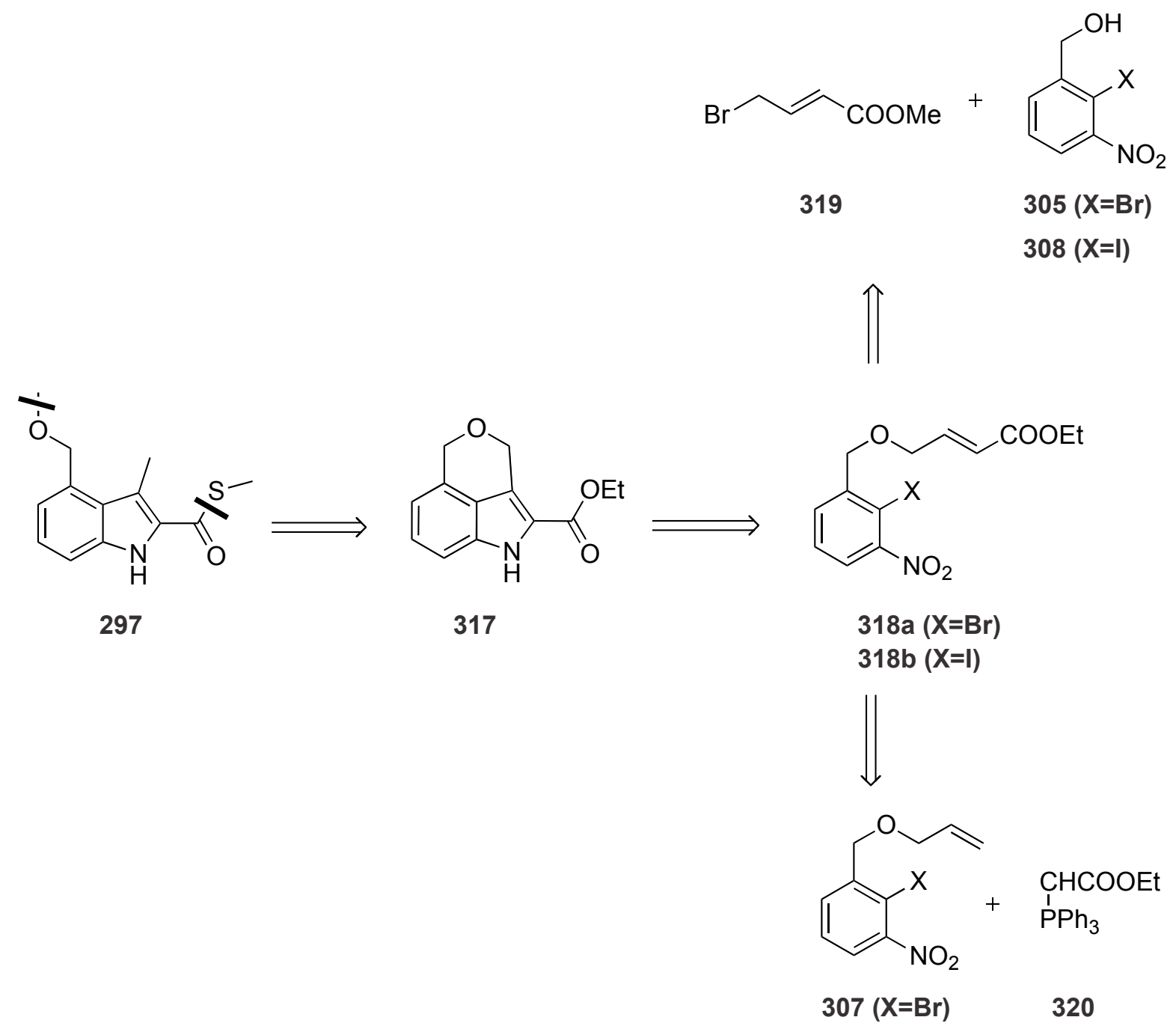

Scheme 93: The second retrosynthetic analysis of the indole fragment

The preparation of the $\alpha, \beta$-unsaturated ester 318a from 2-bromo-3-nitrobenzylalcohol (305) and $y$-bromo-methylcrotonoate (319) met with no success. Hence, it was decided to try the reaction with $y$-hydroxy-methylcrotonoate $(\mathbf{3 2 1})^{133}$ and the benzyl bromide 306. These attempts were also unsuccessful, with the total recovery of the benzylbromide 306 in both attempts (Scheme 94). 
<smiles>O=[N+]([O-])c1cccc(CO)c1Br</smiles>

305<smiles>COC(=O)C=CCBr</smiles>

319

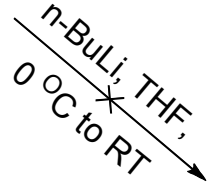<smiles>COC(=O)C=CCO</smiles>

306

321<smiles>CCOC(=O)/C=C/COCc1cccc([N+](=O)[O-])c1Br</smiles><smiles>O=[N+]([O-])c1cccc(CO)c1Br</smiles>

305<smiles>COC(=O)C=CCBr</smiles>

319

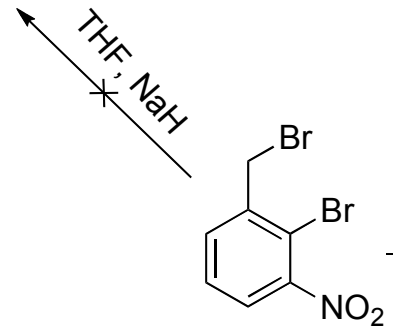

306<smiles>COC(=O)C=CCO</smiles>

321

Scheme 94: Attempted syntheses of compound 318a

\subsection{Conclusion:}

In summary, the synthesis of the indole fragment of nosiheptide via the notable Fischer indole synthesis and the Hemmetsberger synthesis by the Moody group offer the desired compound in excellent yields. Had our attempts to synthesize the heteroannulation precursor been successful, there would have been another significant synthesis of nosiheptide's indole fragment documented in chemical literature. 


\section{Experimental Section}

All NMR spectra were determined at $600 \mathrm{MHz}\left({ }^{1} \mathrm{H}\right.$ NMR $)$ and $150 \mathrm{MHz}\left({ }^{13} \mathrm{C} \mathrm{NMR}\right)$ or $270 \mathrm{MHz}\left({ }^{1} \mathrm{H} \mathrm{NMR}\right)$ and $67.5 \mathrm{MHz}\left({ }^{13} \mathrm{C} \mathrm{NMR}\right)$ in a suitable solvent as stated. The chemical shifts are expressed in $\delta$ values relative to $\mathrm{Me}_{4} \mathrm{Si}\left(0.00,{ }^{1} \mathrm{H}\right.$ and $\left.{ }^{13} \mathrm{C}\right)$ or $\mathrm{CDCl}_{3}$ (7.26, ${ }^{1} \mathrm{H}$ and $77.00,{ }^{13} \mathrm{C}$ ) internal standards. ${ }^{1} \mathrm{H}-{ }^{1} \mathrm{H}$ coupling constants are reported as calculated from spectra; thus, a slight difference between $J_{a, b}$ and $J_{b, a}$ is usually obtained. Results of APT (attached proton test) ${ }^{13} \mathrm{C}$ NMR experiments are shown in parenthesis, where relative to $\mathrm{CDCl}_{3}$, (-) denotes $\mathrm{CH}_{3}$ or $\mathrm{CH}$, and (+) denotes $\mathrm{CH}_{2}$ or $\mathrm{C}$. Tetrahydrofuran (THF), toluene, and diethyl ether were distilled from sodium benzophenone ketyl prior to use. Pyridine, triethylamine, hexanes, acetonitrile, diisopropylamine, and ethyl acetate were distilled from calcium hydride. Chemicals prepared according to literature procedures have been footnoted the first time they are used; all other reagents were obtained from commercial sources and used as received. All reactions were performed under nitrogen atmosphere in oven-dried glassware unless otherwise stated. Solvents were removed from reaction mixtures and products on a rotary evaporator at water aspirator pressure or by bulb-to-bulb distillation under reduced pressure. Chromatography was performed on silica gel 60 (35-75 mm, VWR). Melting points were determined on a MelTemp and are uncorrected. Elemental analyses were performed in the Department of Chemical Engineering, College of Engineering and Mineral Resources, West Virginia University. 


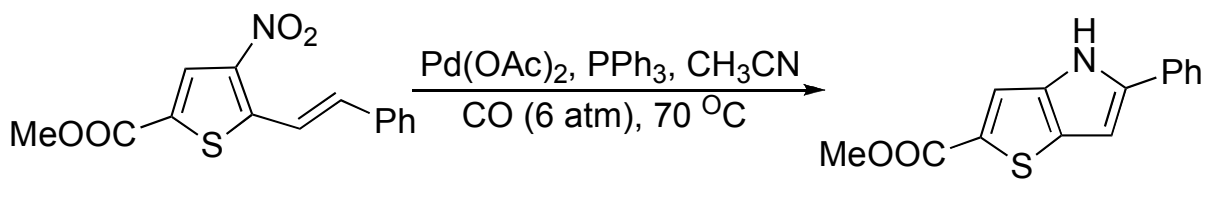

104

108

\section{5-Phenyl-4H-thieno[3,2-b]pyrrole-2-carboxylic acid methyl ester (108) ${ }^{49}$}

To an oven dried, threaded ACE glass pressuretube was added stryryl thiophene 104 (80 mg, $0.264 \mathrm{mmol}), \mathrm{Pd}(\mathrm{OAc})_{2}(4 \mathrm{mg}, 0.0178 \mathrm{mmol})$ and $\mathrm{PPh}_{3}(16.3 \mathrm{mg}, 0.062 \mathrm{mmol})$ in $5 \mathrm{ml}$ of $\mathrm{CH}_{3} \mathrm{CN}$ The tube was fitted with a pressure head, and the solution was saturated with carbon monoxide (four cycles of 6 atm of $\mathrm{CO}$ ). The reaction mixture was heated at $90^{\circ} \mathrm{C}$ (oil bath temperature) under $\mathrm{CO}(6 \mathrm{~atm})$ for $40 \mathrm{~h}$, cooled to room temperature, depressurized and the solvent, removed under reduced pressure. The crude was chromatographed on $\mathrm{SiO}_{2}$ (hexane/ethyl acetate,8:2) to yield 108 (32 mg, $0.118 \mathrm{mmol}, 71 \%)$ as an off-white solid. Mp $244^{\circ} \mathrm{C}$ ( lit $\left.{ }^{49} 239-240{ }^{\circ} \mathrm{C}\right) ;{ }^{1} \mathrm{H}$ NMR $(600$ MHz, DMSO-d 6 , $) \delta 12.03(\mathrm{~s}, 1 \mathrm{H}), 7.78(\mathrm{dd}, J=8.4,1.2 \mathrm{~Hz}, 2 \mathrm{H}), 7.67(\mathrm{~s}, 1 \mathrm{H}), 7.45$ (t, J= $7.8 \mathrm{~Hz}, 2 \mathrm{H}), 7.308(\mathrm{t}, J=7.2,7.8 \mathrm{~Hz}, 1 \mathrm{H}), 6.97(\mathrm{t}, \mathrm{J}=1.2 \mathrm{~Hz}, 1 \mathrm{H}), 3.82(\mathrm{~s}, 3 \mathrm{H}) ;{ }^{13} \mathrm{C}$ NMR (dmso-d 6,600 MHz): $\delta$ 162.9, 141.2, 138.6, 131.8, 130.02, 128.9, 128.1, 127.5, 124.6, 117.4, 98.6, 51.8.

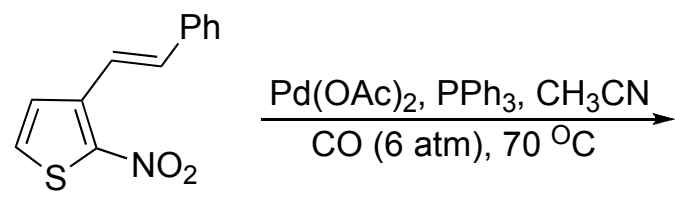

107

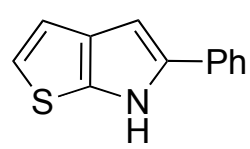

109

\section{5-Phenyl-6H-thieno[2,3-b]pyrrole (109) ${ }^{49}$}

Reaction of 2-nitro-3-styrylthiophene (107) (80 mg, $0.346 \mathrm{mmol}$ ) with carbon monoxide in presence of $\mathrm{Pd}(\mathrm{OAc})_{2}(8 \mathrm{mg}, 0.035 \mathrm{mmol})$ and triphenylphosphine $(37 \mathrm{mg}, 0.141$ 
$\mathrm{mmol}$ ) in $5 \mathrm{ml}$ of $\mathrm{CH}_{3} \mathrm{CN}$ as described above for $104(24 \mathrm{~h})$, gave 109 (57 mg, 0.286 mmol, 83\%) as a pale yellow solid after chromatography (hexanes/EtOAc, 9:1). Mp $179^{\circ} \mathrm{C}\left(\right.$ lit $\left.^{49} 186{ }^{\circ} \mathrm{C}-187^{\circ} \mathrm{C}\right) ;{ }^{1} \mathrm{H}$ NMR $\left(600 \mathrm{MHz}, \mathrm{CDCl}_{3}\right) \delta 8.49(\mathrm{br} \mathrm{s}, 1 \mathrm{H}), 7.53(\mathrm{~d}$, $J=8.4 \mathrm{~Hz}), 7.40$ (dt, J=8.4, 7.2 Hz), $7.25(\mathrm{t}, J=7.8 \mathrm{~Hz}, 1 \mathrm{H}), 7.015(\mathrm{~d}, J=5.4 \mathrm{~Hz}, 1 \mathrm{H}), 6.85$ (d, J=5.4 Hz, 1H), $6.73(\mathrm{~d}, J=1.8 \mathrm{~Hz}, 1 \mathrm{H}) ;{ }^{13} \mathrm{C} \mathrm{NMR}\left(125 \mathrm{MHz}, \mathrm{CDCl}_{3}\right) \delta$ 138.7, 134.9, 133.2, 132.6, 129.2, 126.9, 124.3, 118.5, 117.9, 99.2.
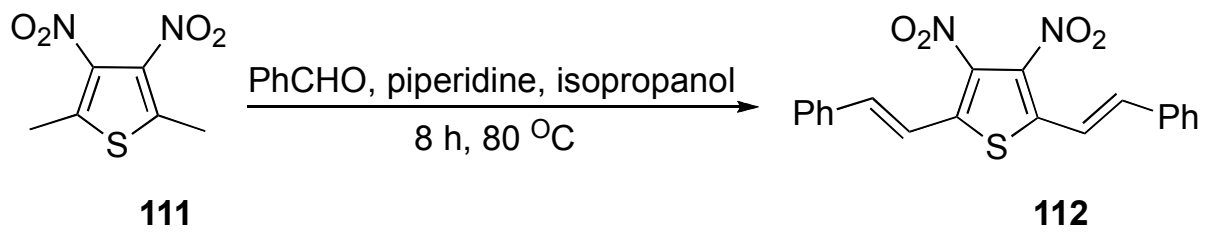

\section{2,5-distyryl-3,4-dinitrothiophene (112) ${ }^{53}$}

To a solution of 3,4-dinitrothioxene $(111)^{52}(250 \mathrm{mg}, 1.404 \mathrm{mmol})$ in absolute methanol (15 ml), freshly distilled benzaldehyde $(602 \mathrm{mg}, 5.679 \mathrm{mmol})$ and 10 drops of pyrrolidine were added. The solution was refluxed for $8 \mathrm{~h}$ during which time, an orange precipitate was seen on the walls of the flask. The flask was cooled to room temperature and then in ice. The orange precipitate was filtered and washed with ice cold methanol $(5 \mathrm{ml})$ and recrystalized from methanol to afford the product $112(357 \mathrm{mg}, 0.994 \mathrm{mmol}, 67 \%)$ as an orange crystalline solid. Mp $230^{\circ} \mathrm{C}-233^{\circ} \mathrm{C}$ (lit53 $227^{\circ} \mathrm{C}$ ); IR (neat) 1536, 1322, 1403 $\mathrm{cm}^{-1} ;{ }^{1} \mathrm{H}$ NMR (600 MHz, DMSO-d 6$): \delta 7.71$ (d, J=6.6 Hz, 4H), 7.58 (d, J=16.2 Hz, 2H), 7.49 (d, J=16.2 Hz, 2H), 7.48-7.42 (m, 3H); ${ }^{13} \mathrm{C}$ NMR (dmso-d $\left.6,125 \mathrm{MHz}\right): \delta$ 139.2, $138.1,135.9,134.6,130.2,129.1,127.8,115.5$. 


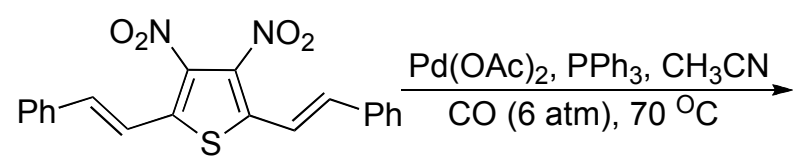

112

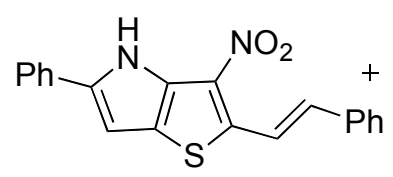

113<smiles></smiles>

114

2-styryl-3-nitro-5-phenyl-4H-thieno[3,2-b]pyrrole (113) ${ }^{53}$ and

\section{3,6-diphenyl-thieno[3,2-b: 4,5-b']dipyrrole (114):}

Reaction of 2,5-distyryl-3,4-dinitrothiophene $(\mathbf{1 1 2})^{53}(80 \mathrm{mg}, 0.211 \mathrm{mmol})$ with carbon monoxide in presence of $\mathrm{Pd}(\mathrm{OAc})_{2}(3 \mathrm{mg}, 0.0134 \mathrm{mmol})$ and triphenylphosphine (14 $\mathrm{mg}, 0.0534 \mathrm{mmol})$ in $4 \mathrm{ml}$ of $\mathrm{CH}_{3} \mathrm{CN}$ as described above for $104(50 \mathrm{~h})$ gave 113 (65 $\mathrm{mg}, 0.188 \mathrm{mmol}, 89 \%$ ) as a dark violet solid after chromatography (hexanes/EtOAc, 8:2). Mp $252^{\circ} \mathrm{C}\left(\mathrm{lit}^{53} 248-249^{\circ} \mathrm{C}\right)$ along with a trace of compound 114.

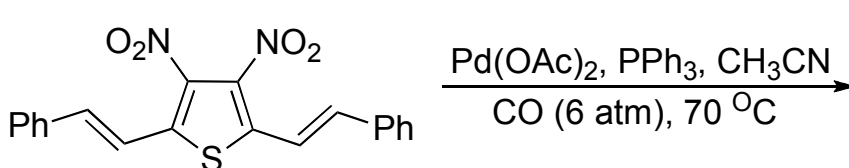

112

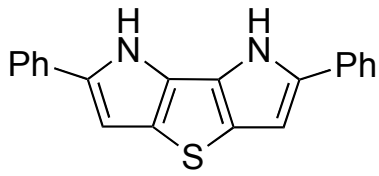

114

4H, 5H-3,6-diphenyl-thieno[3,2-b: 4,5-b']dipyrrole (114)

Reaction of 2,5-distyryl-3,4-dinitrothiophene (112) $)^{53}(104 \mathrm{mg}, 0.275 \mathrm{mmol})$ with carbon monoxide in presence of $\mathrm{Pd}(\mathrm{OAc})_{2}(7 \mathrm{mg}, 0.0311 \mathrm{mmol})$ and triphenylphosphine (31 mg, $0.118 \mathrm{mmol}$ ) in $6 \mathrm{ml}$ of $\mathrm{CH}_{3} \mathrm{CN}$ as described above for 104 (4 days) gave 114 (32 $\mathrm{mg}, 0.102 \mathrm{mmol}, 37 \%$ ) as an off-white solid after chromatography (hexanes/EtOAc, 8:2). Mp $110^{\circ} \mathrm{C}$; IR (neat) 3435, 1599, $1358 \mathrm{~cm}^{-1} ;{ }^{1} \mathrm{H}$ NMR (Acetone-d6, $600 \mathrm{MHz}$ ): $\delta$ 10.415 (s, 2H), 7.66 (d, J= 7.8 Hz, 4H), 7.36 (dt, J=7.2, 8.4 Hz, 4H), 7.18 (dt, J=7.2, 7.8 $\mathrm{Hz}, 2 \mathrm{H}), 6.84(\mathrm{~d}, \mathrm{~J}=1.8 \mathrm{~Hz}, 2 \mathrm{H}) ;{ }^{13} \mathrm{C}$ NMR (125 MHz, Acetone-d6): $\delta$ 135.5, 134.4, 129.8, 127.03, 126.8, 126.6, 124.5, 101.6; HRMS Calcd for $\mathrm{C}_{20} \mathrm{H}_{14} \mathrm{~N}_{2} \mathrm{~S}$ $\left(\mathrm{M}+\mathrm{H}^{+}\right)$314.0873; found, 314.0872. 


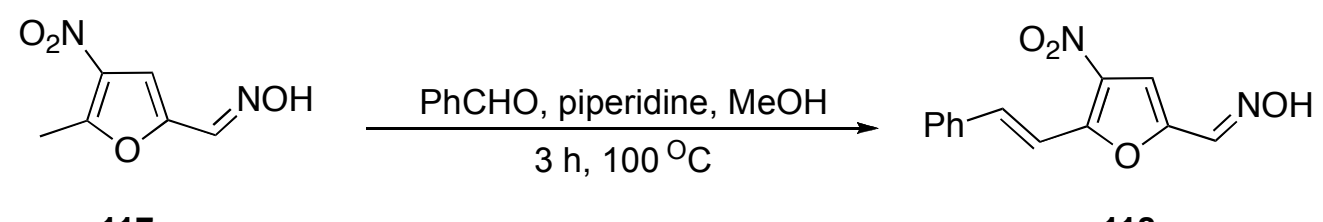
117

118

\section{4-nitro-5-styryl-2-furanaldoxime (118):}

A solution of 5-methyl-4-nitro-2-furanaldoxime $(117)(80 \mathrm{mg}, 0.471 \mathrm{mmol})$ in $5 \mathrm{ml}$ of absolute methanol was refluxed gently for 2 minutes with $0.1 \mathrm{ml}$ of freshly distilled piperidine and followed by the addition of freshly distilled benzaldehyde $(0.247 \mathrm{mg}, 2.33$ $\mathrm{mmol})$. The resulting solution was then refluxed for three hours. An orange solid was seen appearing on the walls of the round-bottomed flask in about 20 minutes. The solution was cooled to room temperature and finally cooled in an ice bath. The orange solid was filtered and washed with $1 \mathrm{ml}$ of ice-cold methanol. The filtrate was evaporated and the obtained orange solid was combined with the filtered orange precipitate and ultimately chromatographed on silica (hexanes/EtOAc, 8:2) to yield 118 (107 mg, 0.4147 mmol, 88\%) as an orange solid. Mp 182-185 ${ }^{\circ} \mathrm{C} ;{ }^{1} \mathrm{H}$ NMR $(600 \mathrm{MHz}$, Acetone-d 6 ): $\delta$ 11.65 (br s, 1H), 7.79 (d, J=16.2 Hz, 1H), 7.69 (d, J=16.8 Hz, 1H), 7.76 (d, J=7.2 Hz, 2H), $7.62(\mathrm{~s}, 1 \mathrm{H}), 7.47-7.50(\mathrm{~m}, 2 \mathrm{H}), 7.45(\mathrm{tt}, \mathrm{J}=7.2,1.2 \mathrm{~Hz}, 1 \mathrm{H}), 7.73(\mathrm{~s}, 1 \mathrm{H})$ ${ }^{13} \mathrm{C}$ NMR $\left(150 \mathrm{MHz}\right.$, Acetone- $\left.\mathrm{d}_{6}\right):$ o 152.3, 144.2, 139.1, 136.4, 135.8, 135.7, 131.1, 130.1, 128.8, 113.75, 113.70; IR (neat) 1619, 1537, 1400, $1346 \mathrm{~cm}^{-1}$; HRMS Calcd for $\mathrm{C}_{13} \mathrm{H}_{10} \mathrm{~N}_{2} \mathrm{O}_{4}\left(\mathrm{M}+\mathrm{H}^{+}\right) 259.0721$; found, 259.0713 . 


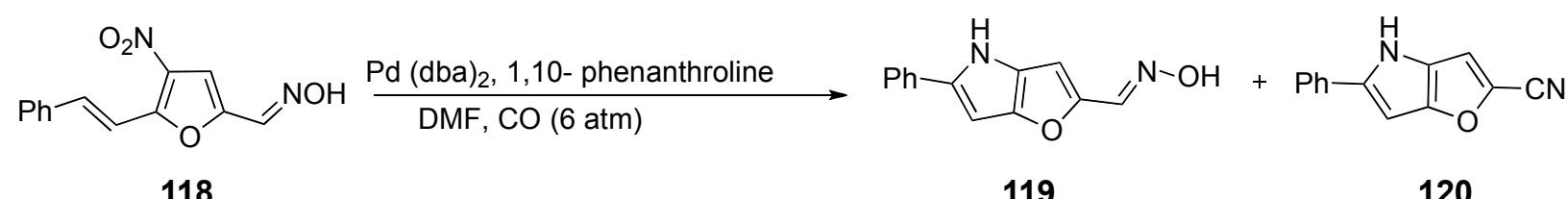

118

119

120

2-cyano-4H-5-phenylfuro[3,2-b]pyrrole (120) and 5-phenyl-4H-furo[3,2-b]pyrrole-2aldoxime (119):

A solution of 4-nitro-5-styryl-2-furanaldoxime (118) $(75 \mathrm{mg}, 0.2907 \mathrm{mmol})$ in $3 \mathrm{ml}$ of dry

DMF, $\mathrm{Pd}(\mathrm{dba})_{2}(10 \mathrm{mg}, 0.0174 \mathrm{mmol})$ and 1,10-phenanthroline $(7 \mathrm{mg}, 0.0353 \mathrm{mmol})$ was heated in presence of carbon monoxide as described for $104\left(120^{\circ} \mathrm{C}, 22 \mathrm{hrs}\right)$. The reaction mixture was cooled to room temperature, diluted with water $(10 \mathrm{ml})$ and extracted with ethyl acetate $(3 \times 20 \mathrm{ml})$. The combined organic layers were washed with water $(2 \mathrm{X} 5 \mathrm{ml})$ and dried over anhydrous $\mathrm{MgSO}_{4}$ to give an oily crude which was chromatographed on silica with (hexanes/EtOAc, 8:2) to yield the 2-cyano-4H-5phenylfuro[3,2-b]pyrrole (120) (12 mg, $0.058 \mathrm{mmol}, 20 \%$ ). Mp 162-163 ${ }^{\circ} \mathrm{C}$; IR (neat) 3310, 2209, $1707 \mathrm{~cm}^{-1}$; ${ }^{1} \mathrm{H}$ NMR (600 MHz, $\left.\mathrm{CDCl}_{3}\right): \delta 8.16$ (br s, 1H), 7.53 (d, J=7.2 Hz, 2H), $7.48(\mathrm{t}, J=7.8 \mathrm{~Hz}, 2 \mathrm{H}), 7.33(\mathrm{t}, J=7.2 \mathrm{~Hz}, 1 \mathrm{H}), 7.10(\mathrm{~s}, 1 \mathrm{H}), 6.47(\mathrm{~s}, 1 \mathrm{H}) ;{ }^{13} \mathrm{C}$ NMR $\left(150 \mathrm{MHz}, \mathrm{CDCl}_{3}\right): \delta 152.7,141.6,132.06,129.2,128.1,126.3,124.6,123.5,113.4$, 109.6, 90.1; HRMS Calcd for $\mathrm{C}_{13} \mathrm{H}_{8} \mathrm{~N}_{2} \mathrm{O}\left(\mathrm{M}+\mathrm{H}^{+}\right)$209.0716, found 209.07094.

Further elution afforded the oxime 119 (30 $\mathrm{mg}, 0.132 \mathrm{mmol}, 45 \%)$, which decomposed on standing at room temperature within a few minutes. ${ }^{1} \mathrm{H} \mathrm{NMR}\left(600 \mathrm{MHz}, \mathrm{CDCl}_{3}\right): \delta$ 8.05 (br s, 1H), 7.98 (s, 1H), 7.51(d, J=7.8 Hz, 2H), 7.39 (t, J=8.4 Hz, 2H), $6.64(\mathrm{~s}, 1 \mathrm{H})$, $6.46(\mathrm{~s}, 1 \mathrm{H})$. 


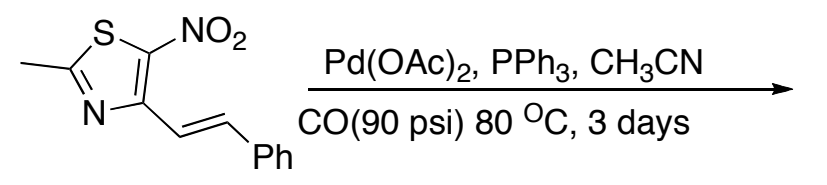

126

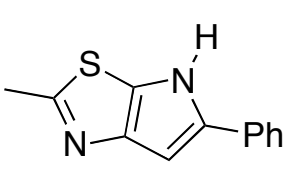

127

\section{2-methyl-5-phenyl-4H-pyrrolo[3,2-d]thiazole (127):}

Reaction of 2-methyl-4-nitro-5-styrylthiazole (126) ${ }^{59}(60 \mathrm{mg}, 0.244 \mathrm{mmol})$ with carbon monoxide in presence of $\mathrm{Pd}(\mathrm{OAc})_{2}$ (4 mg, $0.017 \mathrm{mmol}$ ) and triphenylphosphine (19 mg, $0.0725 \mathrm{mmol}$ ) in $5 \mathrm{ml}$ of $\mathrm{CH}_{3} \mathrm{CN}$ as described above for 104 for $72 \mathrm{~h}$ gave 127 (32 mg, $0.149 \mathrm{mmol}, 61 \%$ ) after chromatography (hexanes/EtOAc, 8:2) as a pale brown solid. Mp 257-258 ${ }^{\circ} \mathrm{C}$ ( decomposed); ${ }^{1} \mathrm{H}$ NMR (600 MHz, DMSO-d 6 ): $\delta 11.82(\mathrm{~s}, 1 \mathrm{H}), 7.67$ (d, $J=7.8 \mathrm{~Hz}, 2 \mathrm{H}), 7.39(\mathrm{t}, J=7.8 \mathrm{~Hz}, 2 \mathrm{H}), 7.21(\mathrm{dt}, J=7.2,7.8 \mathrm{~Hz}, 1 \mathrm{H}), 6.78(\mathrm{~d}, J=1.8 \mathrm{~Hz}$, 1H), 2.68 (s, 3H); ${ }^{13} \mathrm{C}$ NMR (125 MHz, DMSO-d 6 ): $\delta$ 158.5, 147.3, 136.6, 132.8, 128.8, 127.1, 126.2, 123.5, 96.3; IR (neat) 1602, 1458, $1184 \mathrm{~cm}^{-1}$; HRMS Calcd for $\mathrm{C}_{12} \mathrm{H}_{10} \mathrm{~N}_{2} \mathrm{~S}$ $\left(\mathrm{M}+\mathrm{H}^{+}\right)$215.0643; found, 215.06375 .

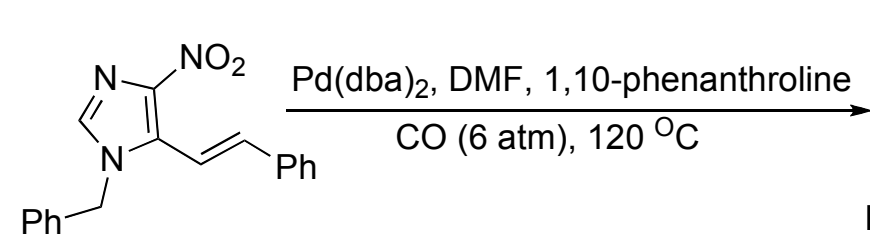

131

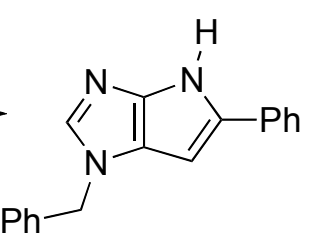

133

\section{1-Benzyl-1,4-dihydro-5-phenylpyrrolo[3,2-d]imidazole (133):}

A solution of 1-benzyl-5-styryl-4-nitroimidazole $(131)^{60}(58 \mathrm{mg}, 0.190 \mathrm{mmol})$ in $2 \mathrm{ml}$ of dry DMF, Pd(dba) 2 (7 mg, $0.012 \mathrm{mmol})$ and 1,10-phenanthroline (5 mg, $0.134 \mathrm{mmol})$ was heated in presence of carbon monoxide as described for 104 at $120^{\circ} \mathrm{C}$ for 6 days. Work up and purifcation of the resulting oily crude by chromatography (hexanes/EtOAc, 8:2, followed by elution with EtOAc) afforded 133 (40 mgs, $0.146 \mathrm{mmol}, 77 \%)$ as a 
brown solid. Mp 244-247 ${ }^{\circ} \mathrm{C} ;{ }^{1} \mathrm{H}$ NMR $(600 \mathrm{MHz}$, Acetone-d6) $\delta 5.32(\mathrm{~s}, 2 \mathrm{H}), 6.29$ (s, 1H), 7.53(s,1H), $7.13(\mathrm{t}, J=7.2 \mathrm{~Hz}, 1 \mathrm{H}), 7.29-7.39(\mathrm{~m}, 7 \mathrm{H}), 7.65$ (d, J=7.2 Hz, 2H), $10.33(\mathrm{~s}, 1 \mathrm{H}) ;{ }^{13} \mathrm{C}$ NMR $\left(150 \mathrm{MHz}\right.$, Acetone-d $\left.\mathrm{d}_{6}\right) \delta$ 138.7, 138.5, 135.3, 135.25, 133.7, $129.58,129.63,128.7,128.67,126.5,124.5,88.85,88.8,50.9$; IR (neat) 1599, 3111, 1470, $1452 \mathrm{~cm}^{-1}$; HRMS calcd for $\mathrm{C}_{18} \mathrm{H}_{15} \mathrm{~N}_{3}\left(\mathrm{M}+\mathrm{H}^{+}\right)$274.1344; found, 274.1338.

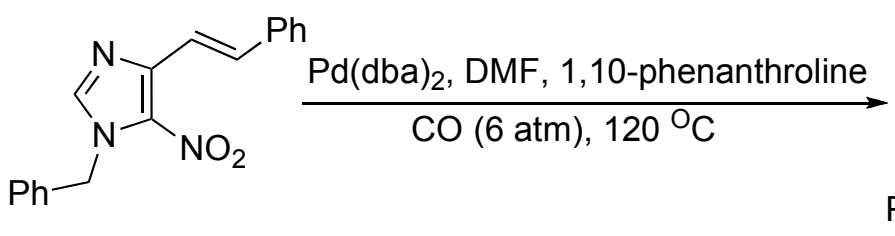

132

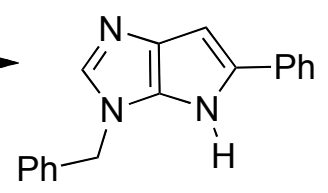

134

\section{3-Benzyl-3,4-dihydro-5-phenylpyrrolo[2,3-d]imidazole (134)}

A solution of 1-Benzyl-4-styryl-5-nitroimidazole $(132)^{60}(125 \mathrm{mg}, 0.409 \mathrm{mmol})$ in $3 \mathrm{ml}$ of dry DMF, Pd(dba)2 (15 mg, $0.012 \mathrm{mmol})$ and 1,10-phenanthroline (27 mg, $0.1361 \mathrm{mmol}$ ) was heated in presence of carbon monoxide as described for 104 at $120^{\circ} \mathrm{C}$ for 3 days. Work up and purifcation of the resulting oily crude by chromatography (hexanes/EtOAc, 8:2, followed by elution with EtOAc) afforded 134 as a brown solid (36 mg, 0.1317 mmol, 32\%). Mp $216^{\circ} \mathrm{C}$ (decomposed); IR (neat) 1599, 1383, $1219 \mathrm{~cm}^{-1}$;

${ }^{1} \mathrm{H}$ NMR $\left(600 \mathrm{MHz}\right.$, Acetone- $\left.\mathrm{d}_{6}\right): \delta 5.37(\mathrm{~s}, 2 \mathrm{H}), 6.55(\mathrm{~s}, 1 \mathrm{H}), 7.44(\mathrm{~s}, 1 \mathrm{H}), 7.12(\mathrm{t}, J=$ 7.2 Hz, 1H), 7.28-7.36 (m, 7H), 7.558 (d, J=8.4 Hz, 2H), 10.28 (s, 1H); ${ }^{13} \mathrm{C}$ NMR (150 MHz, Acetone-d $\left.\mathrm{d}_{6}\right): \delta$ 138.5, 138.0, 136.2, 135.4, 129.7, 129.6, 128.6, 128.0, 126.3, 124.3, 95.9, 95.8, 49.4; HRMS Calcd for $\mathrm{C}_{18} \mathrm{H}_{15} \mathrm{~N}_{3}\left(\mathrm{M}+\mathrm{H}^{+}\right)$274.1344; found, 274.1338. 


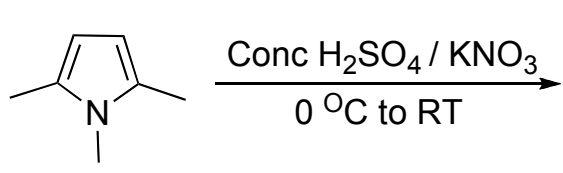

139

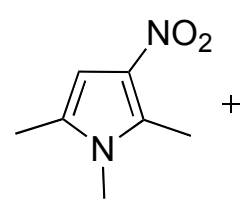

140

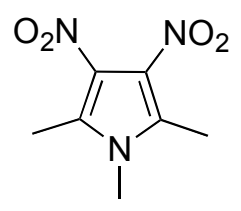

141

1,2,5-trimethyl-3-nitropyrrole (140) and 1,2,5-trimethyl-3,4-dinitropyrrole (141):

To concentrated sulphuric acid $(10 \mathrm{ml})$ at $0^{\circ} \mathrm{C}$, was added 1,2,5-trimethylpyrrole (139) (1.042 gm, $9.648 \mathrm{mmol}$ ) slowly, during which time the temperature rises to $15^{\circ} \mathrm{C}$. Cool it again to $0^{\circ} \mathrm{C}$, and potassium nitrate $(2.078 \mathrm{gm}, 20.574 \mathrm{mmol})$ is added in portions. The resulting solution is stirred at $0^{\circ} \mathrm{C}$ for 10 minutes. The temperature is then slowly allowed to rise up to room temperature and the stirring is continued for a further 30 minutes. The mixture is poured into crushed ice with vigorous stirring, when an yellow solid separates. The yellow precipitate is filtered, washed with cold water, dried and chromatographed (hexanes/EtOAc, 6:4) to afford 140 (705 mg, $4.578 \mathrm{mmol}, 47 \%$ ) as an yellow solid. Mp 115-116 ${ }^{\circ} \mathrm{C}\left(\right.$ lit $\left.^{64} \mathrm{mp} 113^{\circ} \mathrm{C}\right)$; Further elution gave 141 (40 mg, 0.201 mmol, $2 \%)$ as a pale yellow solid. $\mathrm{Mp} 207-210^{\circ} \mathrm{C} .{ }^{1} \mathrm{H}$ NMR $\left(270 \mathrm{MHz}, \mathrm{CDCl}_{3}\right): \delta 3.48$ (s, 1H), 2.48 (s, 2H); ${ }^{13} \mathrm{C}$ NMR (67.5 MHz, $\left.\mathrm{CDCl}_{3}\right): \delta$ 131.3, 128.9, 31.4, 10.9; HRMS calcd. for $\mathrm{C}_{7} \mathrm{H}_{9} \mathrm{~N}_{3} \mathrm{O}_{4}\left(\mathrm{M}+\mathrm{H}^{+}\right)$200.0671, found 200.0666 . 


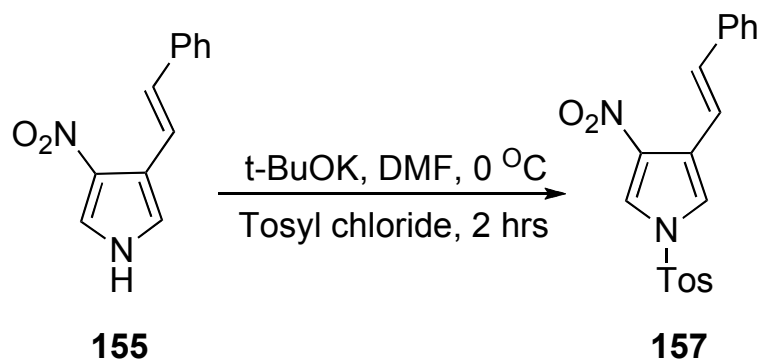

\section{3-nitro-4-styryl-1-tosylpyrrole (157):}

To a solution of 3-nitro-4-styrylpyrrole $(\mathbf{1 5 5})^{67}(190 \mathrm{mg}, 0.888 \mathrm{mmol})$ in anhydrous DMF $(10 \mathrm{ml})$, was added BuOK (132 $\mathrm{mg}, 1.179 \mathrm{mmol})$ at $0{ }^{\circ} \mathrm{C}$, and the resulting orange solution was allowed to stir at $0^{\circ} \mathrm{C}$ under an inert atmosphere for $45 \mathrm{~min}$. A solution of tosyl chloride $(224 \mathrm{mg}, 1.179 \mathrm{mmol})$ in DMF $(1 \mathrm{ml})$ was then added to the above solution with a syringe; the solution turns yellow upon the addition. The reaction mixture was continued to stir under an atmosphere of nitrogen at $0{ }^{\circ} \mathrm{C}$ for $2.5 \mathrm{~h}$. Aqueous work up at this stage followed by extraction with ethylacetate $(2 \mathrm{X} 25 \mathrm{ml})$, washing of the organic phase with water $(2 \mathrm{X} 25 \mathrm{ml})$, drying $\left(\mathrm{MgSO}_{4}\right)$, and concentration gave an yellow crude that was purified on a short column of $\mathrm{Al}_{2} \mathrm{O}_{3}$ (hexanes/EtOAc, 8:2) to afford the product $157(257 \mathrm{mg}, 0.698 \mathrm{mmol}, 79 \%)$ as an yellow solid. Mp 124-125 ${ }^{\circ} \mathrm{C}$. ${ }^{1} \mathrm{H} \mathrm{NMR}\left(600 \mathrm{MHz}, \mathrm{CDCl}_{3}\right): \delta 8.00(\mathrm{~d}, J=2.8 \mathrm{~Hz}, 1 \mathrm{H}), 7.87$ (d, J=8.5 Hz, 2H), 7.48 (d, $J=8.5 \mathrm{~Hz}, 2 \mathrm{H}), 7.34-7.44(\mathrm{~m}, 6 \mathrm{H}), 7.40(\mathrm{dd}, J=16.2,0.8 \mathrm{~Hz}, 1 \mathrm{H}), 7.30$ (tt, J=7.3, $1.7 \mathrm{~Hz}$, $1 \mathrm{H}), 6.94(\mathrm{~d}, \mathrm{~J}=16.5 \mathrm{~Hz}, 1 \mathrm{H}), 2.46(\mathrm{~s}, 3 \mathrm{H}) ;{ }^{13} \mathrm{C}$ NMR $\left(67.5 \mathrm{MHz}, \mathrm{CDCl}_{3}\right): \delta 147.1,137.3$, 136.5, 134.2, 132.3, 130.8, 128.9, 128.4, 127.8, 126.8, 122.3, 121.8, 117.0, 116.4, 21.9; IR (neat) 1489, 1370, 1057, $964 \mathrm{~cm}^{-1}$; HRMS calcd. for $\mathrm{C}_{19} \mathrm{H}_{16} \mathrm{~N}_{2} \mathrm{O}_{4} \mathrm{~S}\left(\mathrm{M}+\mathrm{H}^{+}\right) 369.0909$, found 369.0903 . 


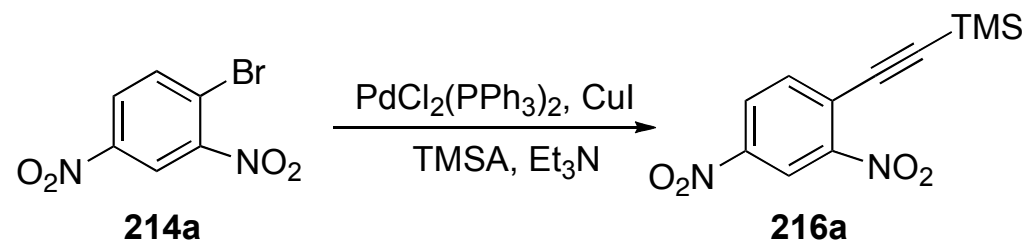

\section{2,4-Dinitro-1-[2-(trimethylsilyl)ethynyl]benzene (216a)}

To a solution of 2,4-dinitro-1-bromobenzene $(\mathbf{2 1 4 a})(750 \mathrm{mg}, 3.03 \mathrm{mmol})$ prepared in triethylamine $\left(\mathrm{Et}_{3} \mathrm{~N}, 20 \mathrm{ml}\right)$, trimethylsilylethyne (329 mg, $\left.3.35 \mathrm{~mol}\right)$, Cul (58 mg, 0.304 $\mathrm{mmol})$ and $\mathrm{PdCl}_{2}\left(\mathrm{PPh}_{3}\right)_{2}(214 \mathrm{mg}, 0.304 \mathrm{mmol})$ were added and the reaction mixture was stirred under an atmosphere of nitrogen for 24 hours. The solvent was removed under reduced pressure, and the dark crude obtained was purified by chromatography (hexanes/EtOAc, 9:1) to afford 216a (336 mg, $1.42 \mathrm{mmol}, 47 \%$ ) as an yellow solid. Mp 82-83 ${ }^{\circ} \mathrm{C} ;{ }^{1} \mathrm{H}$ NMR $\left(600 \mathrm{MHz}, \mathrm{CDCl}_{3}\right): \delta 8.87(\mathrm{~d}, \mathrm{~J}=1.8 \mathrm{~Hz}, 1 \mathrm{H}), 7.83(\mathrm{~d}, J=9 \mathrm{~Hz}$, 1H), 8.39 (dd, J=8.4, J=2.4 Hz, $1 \mathrm{H}), 0.31$ (s, 9H); $\left.{ }^{13} \mathrm{C} \mathrm{NMR} \mathrm{(125} \mathrm{MHz,} \mathrm{CDCl}_{3}\right)$ :

$\delta$ 150.1, 146.5, 136.2, 126.7, 124.3, 120.1, 111.4, 97.7, -0.64; IR (neat) 3092, 2962, $1594 \mathrm{~cm}^{-1} ;$ Anal calcd for $\mathrm{C}_{11} \mathrm{H}_{12} \mathrm{~N}_{2} \mathrm{O}_{4} \mathrm{Si}: \mathrm{C}, 49.99 ; \mathrm{H} 4.58 ; \mathrm{N}, 10.60$. Found: $\mathrm{C}, 50.26 ; \mathrm{H}$ 4.58; N, 10.38.

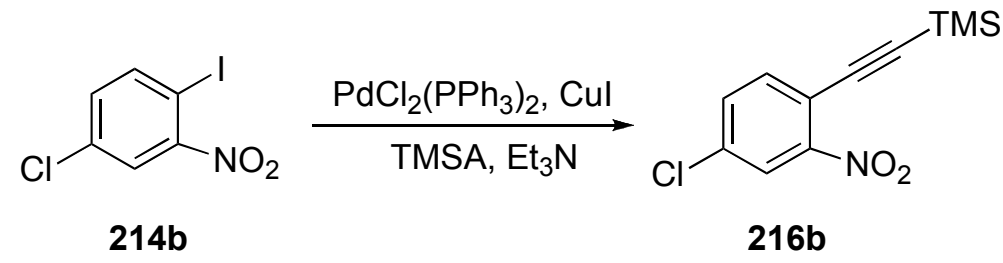

\section{4-Chloro-2-nitro-1-[2-(trimethylsilyl)ethynyl]benzene (216b):}

Reaction of 4-chloro-2-nitro-1-iodobenzene (214a) (700 mg, $2.49 \mathrm{mmol})$ with trimethylsilylethyne (290 mg, $2.95 \mathrm{~mol})$, Cul (38 mg, $0.12 \mathrm{mmol})$ and $\mathrm{PdCl}_{2}\left(\mathrm{PPh}_{3}\right)_{2}(20$ $\mathrm{mg}, 0.02 \mathrm{mmol}$ ) in triethylamine $\left(\mathrm{Et}_{3} \mathrm{~N}, 30 \mathrm{ml}\right.$ ), as described above for 216a (room temperature, 22 hours) afforded $\mathbf{2 1 6 b}$ (583 $\mathrm{mg}, 2.29 \mathrm{~mol}, 92 \%$ ) as an yellow solid after 
chromatography (hexanes/EtOAc, 95:5). Mp 44-47 ${ }^{\circ} \mathrm{C} ;{ }^{1} \mathrm{H}$ NMR $\left(270 \mathrm{MHz}, \mathrm{CDCl}_{3}\right): \delta$ $7.99(\mathrm{~d}, J=2.1 \mathrm{~Hz}, 1 \mathrm{H}), 7.56(\mathrm{~d}, J=8.3 \mathrm{~Hz}, 1 \mathrm{H}), 7.49$ (dd, J=8.5, $2 \mathrm{~Hz}, 1 \mathrm{H}), 0.24(\mathrm{~s}, 9 \mathrm{H})$; ${ }^{13} \mathrm{C}$ NMR $\left(67.5 \mathrm{MHz}, \mathrm{CDCl}_{3}\right){ }^{134}: \delta 150.2,135.8,134.5,132.8,124.6,116.7,105.0,98.2$, -0.57; IR (neat) 3096, 2961, $2164 \mathrm{~cm}^{-1}$; Anal calcd for $\mathrm{C}_{11} \mathrm{H}_{12} \mathrm{CINO}_{2} \mathrm{Si}$ : C, 52.06; H 4.77; N, 5.52. Found: C, 52.37; H, 4.86; N, 5.87.

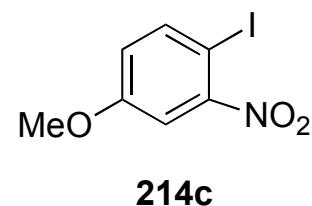

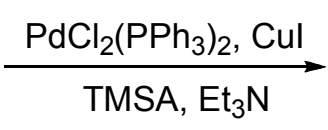

214c

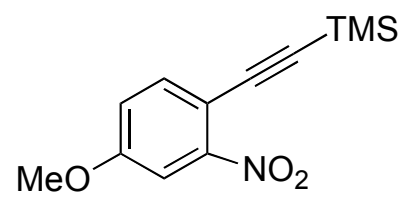

216c

\section{4-Methoxy-2-nitro-1-[2-(trimethylsilyl)ethynyl]benzene (216c):}

Reaction of 4-methoxy-2-nitro-1-iodobenzene (214c) $(500 \mathrm{mg}, 1.79 \mathrm{mmol})$ with trimethylsilylethyne (206 mg, $2.09 \mathrm{mmol})$, Cul (30 mg, $0.157 \mathrm{mmol}$ ) and $\mathrm{PdCl}_{2}\left(\mathrm{PPh}_{3}\right)_{2}$ (63 mg, $0.09 \mathrm{mmol}$ ) in triethylamine $\left(\mathrm{Et}_{3} \mathrm{~N}, 30 \mathrm{ml}\right.$ ), as described above for $\mathbf{2 1 6 a}$ (room temperature, 40 hours) afforded $216 \mathrm{c}(425 \mathrm{mg}, 0.95 \mathrm{~mol}, 95 \%)$ as a pale yellow solid after chromatography (hexanes/EtOAc, 9:1). Mp 68-69 ${ }^{\circ} \mathrm{C} ;{ }^{1} \mathrm{H}$ NMR $\left(600 \mathrm{MHz}, \mathrm{CDCl}_{3}\right)$ : $\delta 7.53$ (d, J=9 Hz, 1H), 7.51 (d, J=2.4 Hz, 1H), 7.08 (dd, J=9, $3 \mathrm{~Hz}, 1 \mathrm{H}), 3.88$ (s, 3H), 0.27 (s, 9H); ${ }^{13} \mathrm{C} N M R\left(125 \mathrm{MHz}, \mathrm{CDCl}_{3}\right): \delta$ 159.8, 151.3, 136.2, 119.7, 110.8, 109.4, 101.6, 99.6, 56.2, -0.11; IR (neat) 2161, 1620, $1530 \mathrm{~cm}^{-1}$; Anal calcd for $\mathrm{C}_{12} \mathrm{H}_{15} \mathrm{NO}_{3} \mathrm{Si}$ : C, 57.80; H 6.06; N, 5.62. Found: C, 58.39; H 6.55; N, 5.30. 
<smiles>COc1ccc([N+](=O)[O-])c(I)c1</smiles>

214d

$$
\underset{\mathrm{PdCl}_{2}\left(\mathrm{PPh}_{3}\right)_{2}, \mathrm{Cul}}{\stackrel{\mathrm{TMSA}, \mathrm{Et}_{3} \mathrm{~N}}{\longrightarrow}}
$$

5-Methoxy-2-nitro-1-[2-(trimethylsilyl)ethynyl]benzene (216d):

Reaction of 5-methoxy-2-nitro-1-iodobenzene $(\mathbf{2 1 4 d})(1.01 \mathrm{gm}, 3.62 \mathrm{mmol})$ with trimethylsilylethyne (399 mg, $4.06 \mathrm{mmol})$, $\mathrm{Cul}(60 \mathrm{mg}, 0.315 \mathrm{mmol})$ and $\mathrm{PdCl}_{2}\left(\mathrm{PPh}_{3}\right)_{2}$ (123 $\mathrm{mg}, 0.175 \mathrm{mmol}$ ) in triethylamine $\left(E t_{3} \mathrm{~N}, 25 \mathrm{ml}\right.$ ), as described above for $216 \mathrm{a}$ (room temperature, 18 hours) afforded $\mathbf{2 1 6 d}(790 \mathrm{mg}, 3.36 \mathrm{~mol}, 92 \%)$ as an yellow solid after chromatography (hexanes/EtOAc, 8:2). Mp 65-68 ${ }^{\circ} \mathrm{C} ;{ }^{1} \mathrm{H} \mathrm{NMR}\left(600 \mathrm{MHz}, \mathrm{CDCl}_{3}\right): \delta$ 8.07 (d, J=9.6 Hz, 1H), 7.07 (d, J=2.4 Hz, 1H), 6.91 (dd, J=9, $3 \mathrm{~Hz}, 1 \mathrm{H}), 3.89$ (s, 3H), 0.29 (s, 9H); ${ }^{13} \mathrm{C} \mathrm{NMR}\left(125 \mathrm{MHz}, \mathrm{CDCl}_{3}\right): \delta$ 162.9, 143.4, 127.2, 120.9, 119.2, 115.1, 103.8, 100.1, 56.2, -0.14; IR (neat) 2966, 2898, 2165,1602 $\mathrm{cm}^{-1}$; Anal calcd for $\mathrm{C}_{12} \mathrm{H}_{15} \mathrm{NO}_{3} \mathrm{Si}: \mathrm{C}, 57.80 ; \mathrm{H} 6.06 ; \mathrm{N}, 5.62$. Found: C, 57.97; H 6.31; N, 5.77.<smiles>Cc1cccc(I)c1[N+](=O)[O-]</smiles>

214e

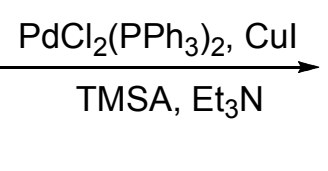
TMSA, $\mathrm{Et}_{3} \mathrm{~N}$

\section{3-Methyl-2-nitro-1-[2-(trimethylsilyl)ethynyl]benzene (216e):}

Reaction of 3-methyl-2-nitro-1-iodobenzene (214e) $(1.70 \mathrm{gm}, 6.45 \mathrm{mmol})$ with trimethylsilylethyne (690 mg, $7.03 \mathrm{mmol})$, Cul (123 mg, $0.646 \mathrm{mmol}$ ) and $\mathrm{PdCl}_{2}\left(\mathrm{PPh}_{3}\right)_{2}$ (274 $\mathrm{mg}, 0.390 \mathrm{mmol}$ ) in triethylamine $\left(\mathrm{Et}_{3} \mathrm{~N}, 25 \mathrm{ml}\right.$ ), as described above for $216 \mathrm{a}$ (room temperature, 26 hours) afforded $216 \mathrm{e}(1.366 \mathrm{gm}, 5.86 \mathrm{~mol}, 91 \%)$ as an oil, that turns into a solid in the freezer after chromatography (hexanes/EtOAc, 95:5). ${ }^{1} \mathrm{H}$ NMR (600 
$\left.\mathrm{MHz}, \mathrm{CDCl}_{3}\right): \delta 7.39$ (d, J=7.8 Hz, 1H), $7.29(\mathrm{t}, J=7.8 \mathrm{~Hz}, 1 \mathrm{H}), 7.23(\mathrm{~d}, J=7.8 \mathrm{~Hz}, 1 \mathrm{H})$, $2.32(\mathrm{~s}, 3 \mathrm{H}), 0.23(\mathrm{~s}, 9 \mathrm{H}) ;{ }^{13} \mathrm{C} \mathrm{NMR}\left(125 \mathrm{MHz}, \mathrm{CDCl}_{3}\right): \delta$ 153.2, 131.3, 130.9, 129.9, $129.8,116.2,101.8,97.8,17.4,-0.50$; IR (neat) 2962, 2160, $1600 \mathrm{~cm}^{-1}$; Anal calcd for $\mathrm{C}_{12} \mathrm{H}_{15} \mathrm{NO}_{2} \mathrm{Si}: \mathrm{C}, 61.77 ; \mathrm{H} 6.48 ; \mathrm{N}, 6.00$. Found: C, 62.28; H 6.64; N, 6.30.

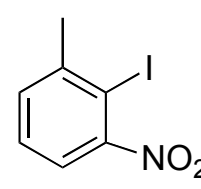

$214 \mathrm{~g}$

$$
\underset{\mathrm{PdCl}_{2}\left(\mathrm{PPh}_{3}\right)_{2}, \mathrm{Cul}, \mathrm{Et}_{3} \mathrm{~N}}{\longrightarrow}
$$

$216 \mathrm{~g}$

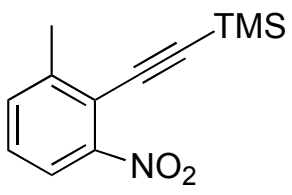

\section{6-Methyl-2-nitro-1-[2-(trimethylsilyl)ethynyl]benzene (216g):}

Reaction of 6-methyl-2-nitro-1-iodobenzene $(214 \mathrm{~g})(1.50 \mathrm{gm}, 5.70 \mathrm{mmol})$ with trimethylsilylethyne (626 mg, $6.37 \mathrm{mmol})$, Cul (90 mg, $0.473 \mathrm{mmol}$ ) and $\mathrm{PdCl}_{2}\left(\mathrm{PPh}_{3}\right)_{2}$ $(210 \mathrm{mg}, 0.300 \mathrm{mmol})$ in triethylamine $\left(\mathrm{Et}_{3} \mathrm{~N}, 25 \mathrm{ml}\right)$, as described above for $216 \mathrm{a}(50$ ${ }^{\circ} \mathrm{C}, 27$ hours) afforded $216 \mathrm{~g}$ (649 mg, $2.78 \mathrm{mmol}, 49 \%$ ) as an oil (turns into an yellow solid in the freezer) after chromatography (hexanes/EtOAc, 95:5). ${ }^{1} \mathrm{H} N M R(600 \mathrm{MHz}$, $\left.\mathrm{CDCl}_{3}\right): \delta 7.76$ (d, J=8.4 Hz, 1H), 7.45 (d, J=7.2 Hz, 1H), 7.30 (t, J=8.1 Hz, $\left.1 \mathrm{H}\right), 2.51$ (s, 3H), 0.28 (s, 9H); ${ }^{13} \mathrm{C} \mathrm{NMR}\left(125 \mathrm{MHz}, \mathrm{CDCl}_{3}\right): \delta$ 151.0, 143.7, 133.6, 127.9, 121.6, 117.6, 108.5, 97.6, 21.2, -0.34; IR (neat) 2960, 1528, 1346, $1249 \mathrm{~cm}^{-1}$; HRMS calcd for $\mathrm{C}_{12} \mathrm{H}_{15} \mathrm{NO}_{2} \mathrm{Si}\left(\mathrm{M}+\mathrm{H}^{+}\right) 234.0950$, found 234.0946. 


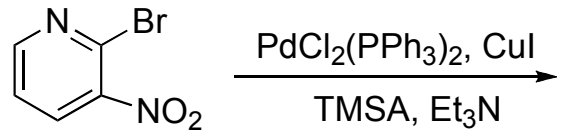

218

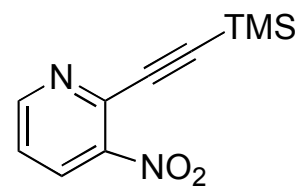

219

\section{3-Nitro-1-[2-(trimethylsilyl)ethynyl]pyridine (219):}

Reaction of 2-bromo-3-nitro-pyridine (218) (502 mg, $2.47 \mathrm{mmol}$ ) with trimethylsilylethyne (291 mg, $2.96 \mathrm{mmol})$, Cul (55 mg, $0.289 \mathrm{mmol})$ and $\mathrm{PdCl}_{2}\left(\mathrm{PPh}_{3}\right)_{2}(94 \mathrm{mg}, 0.134 \mathrm{mmol})$ in triethylamine $\left(\mathrm{Et}_{3} \mathrm{~N}, 25 \mathrm{ml}\right)$, as described above for $\mathbf{2 1 6 a}$ (room temperature, 54 hours) afforded 219 (388 mg, $1.98 \mathrm{mmol}, 80 \%$ ) as a brown solid after chromatography (hexanes/EtOAc, 8:2). Mp 36-38 ${ }^{\circ} \mathrm{C} ;{ }^{1} \mathrm{H}$ NMR (600 MHz, $\mathrm{CDCl}_{3}$ ): $\delta 8.79$ (dd, J=1.2, 4.8 $\mathrm{Hz}, 1 \mathrm{H}), 8.32$ (dd, J=8.4, $1.8 \mathrm{~Hz}, 1 \mathrm{H}), 7.43(\mathrm{dd}, \mathrm{J}=8.4,4.2 \mathrm{~Hz}, 1 \mathrm{H}), 0.31(\mathrm{~s}, 9 \mathrm{H}) ;{ }^{13} \mathrm{C}$ NMR (125 MHz, $\left.\mathrm{CDCl}_{3}\right): \delta$ 137.0, 132.4, 123.2, 105.6, 98.9, -0.47; IR (neat) 2962, 2160, $1591,1527 \mathrm{~cm}^{-1}$

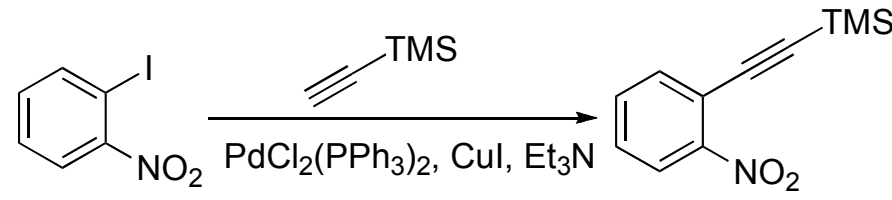

214 216

\section{1-Nitro-2-[2-(trimethylsilyl)ethynyl]benzene (216):}

Reaction of 214 (3.00 gm, $12.00 \mathrm{mmol})$ with trimethylsilylethyne (1.607 gm, $16.4 \mathrm{mmol})$, Cul (192 mg, $1.01 \mathrm{mmol})$ and $\mathrm{PdCl}_{2}\left(\mathrm{PPh}_{3}\right)_{2}(423 \mathrm{mg}, 0.602 \mathrm{mmol})$ in triethylamine (50 $\mathrm{ml}$ ), as described above for 216a (72 h) afforded $216^{94}(2.652 \mathrm{gm}, 12.01 \mathrm{mmol})$ as an yellow oil after chromatography (hexanes/EtOAc, 95:5) in a quantitative yield. 


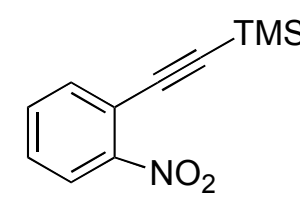

216

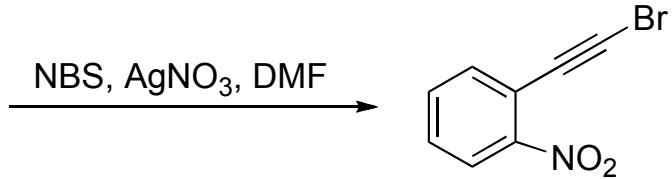

$212 a$

\section{2-[2-Bromoethynyl]-1-nitrobenzene ${ }^{99}$ (212a):}

To a solution of 216 in anhydrous DMF $(10 \mathrm{ml})$, silver nitrate $(134 \mathrm{mg}, 0.078 \mathrm{mmol})$ was added and the flask was covered with an aluminium foil. It was cooled in ice and $\mathrm{N}$ bromosuccinimide $(1.38 \mathrm{gm}, 7.75 \mathrm{mmol})$ was added in portions. The reaction mixture was allowed to warm to room temperature and continued to stir for 22 hours. The reaction mixture was cooled in ice and ice water $(20 \mathrm{ml})$ was added and the mixture was extracted with diethyl ether $(3 \times 20 \mathrm{ml})$. The combined organic layers were washed with water $(3 \mathrm{X} 20 \mathrm{ml})$, dried over anhydrous $\mathrm{MgSO}_{4}$ and filtered. The solvents were removed under reduced pressure and the crude was purified by chromatography (hexanes/ EtOAc, 8:2) to yield $212 \mathrm{a}(1.358 \mathrm{gm}, 6.00 \mathrm{mmol}, 80 \%)$ as a brown solid. Mp $98-102{ }^{\circ} \mathrm{C}$ (lit $\left.{ }^{101} 94-98^{\circ} \mathrm{C}\right)$.

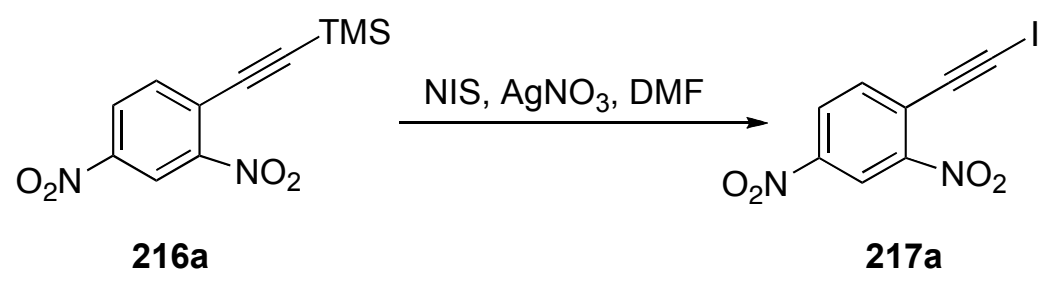

\section{2,4-Dinitro-1-[2-iodoethynyl]benzene (217a):}

Reaction between $216 \mathrm{a}(182 \mathrm{mg}, 0.77 \mathrm{mmol})$ and NIS (192 mg, $0.85 \mathrm{mmol})$ in presence of silver nitrate $(13 \mathrm{mg}, 0.076 \mathrm{mmol})$ in anhydrous DMF $(5 \mathrm{ml})$ as described above for 212a (4 h) afforded the product $217 \mathrm{a}(219 \mathrm{mg}, 0.689 \mathrm{mmol}, 89 \%)$ as an yellow solid ${ }^{135}$ after work up and chromatography (hexanes/EtOAc, 85:15). Mp 112-113 ${ }^{\circ} \mathrm{C} ;{ }^{1} \mathrm{H}$ NMR 
(600 MHz, $\left.\mathrm{CDCl}_{3}\right): \delta 8.90(\mathrm{~d}, J=2.4 \mathrm{~Hz}, 1 \mathrm{H}), 8.42(\mathrm{dd}, J=8.4,2.4 \mathrm{~Hz}, 1 \mathrm{H}), 7.84(\mathrm{~d}, J=9$

$\mathrm{Hz}, 1 \mathrm{H}) ;{ }^{13} \mathrm{C}$ NMR $\left(125 \mathrm{MHz}, \mathrm{CDCl}_{3}\right): \delta$ 146.9, 137.3, 127.1, 124.6, 120.5, 92.8, 88.3, 25.9; IR (neat) 3094, 2161, $1592 \mathrm{~cm}^{-1}$.

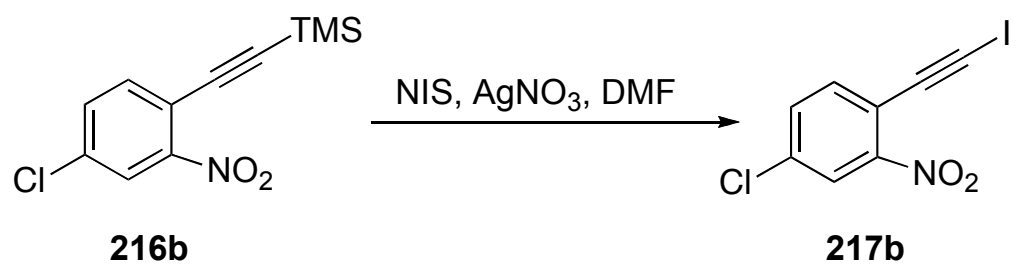

\section{4-chloro-2-nitro-1-[2-iodoethynyl]benzene (217b):}

Reaction between 216b (485 mg, $1.91 \mathrm{mmol})$ and NIS (477 mg, $2.11 \mathrm{mmol})$ in presence of silver nitrate $(40 \mathrm{mg}, 0.23 \mathrm{mmol})$ in anhydrous DMF $(10 \mathrm{ml})$ as described above for 212a (3 $\mathrm{h}$ ) afforded the product $\mathbf{2 1 7 \mathbf { b } ^ { 1 3 8 }}$ (523 $\left.\mathrm{mg}, 1.70 \mathrm{mmol}, 89 \%\right)$ as an yellow solid after work up and chromatography (hexanes/EtOAc, 8:2). Mp 94-96 ${ }^{\circ} \mathrm{C} ;{ }^{1} \mathrm{H}$ NMR (270 $\left.\mathrm{MHz}, \mathrm{CDCl}_{3}\right): \delta 8.05$ (d, J=1.6 Hz, 1H); 7.59 (d, J=8.9 Hz, 1H), 7.55 (dd, J=8.3, $1.8 \mathrm{~Hz}$, $1 \mathrm{H}) ;{ }^{13} \mathrm{C} \operatorname{NMR}\left(67.5 \mathrm{MHz}, \mathrm{CDCl}_{3}\right)^{136}: \delta 150.4,136.6,135,133.0,124.8,116.9,88.0$, 18.7; IR 2165, $1555 \mathrm{~cm}^{-1}$.

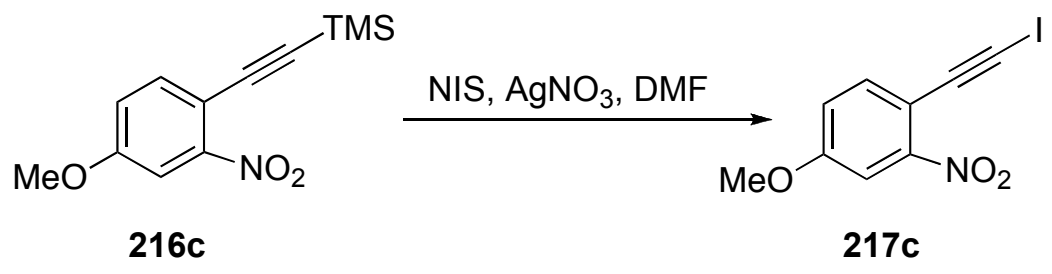

\section{4-Methoxy -2-nitro-1-[2-iodoethynyl]benzene (217c):}

Reaction between 216c (100 mg, $0.42 \mathrm{mmol})$ and NIS (107 mg, $0.47 \mathrm{mmol})$ in presence of silver nitrate ( $37 \mathrm{mg}, 0.22 \mathrm{mmol}$ ) in anhydrous DMF ( $3 \mathrm{ml})$ as described above for 212a (2 $\mathrm{h})$ afforded the product $\mathbf{2 1 7 \mathrm { c } ^ { 1 3 8 }}(99 \mathrm{mg}, 0.33 \mathrm{mmol}, 77 \%)$ as an yellow solid after work up and chromatography (hexanes/EtOAc, 8:2). Mp 92-94 ${ }^{\circ} \mathrm{C} ;{ }^{1} \mathrm{H}$ NMR $(270$ 
$\left.\mathrm{MHz}, \mathrm{CDCl}_{3}\right): \delta 7.54(\mathrm{~d}, J=8.6 \mathrm{~Hz}, 1 \mathrm{H}), 7.53(\mathrm{~d}, \mathrm{~J}=2.7 \mathrm{~Hz}, 1 \mathrm{H}), 7.10$ (dd, J=8.6, 2.7 Hz, $1 \mathrm{H}) ;{ }^{13} \mathrm{C}$ NMR $\left(67.5 \mathrm{MHz}, \mathrm{CDCl}_{3}\right): \delta 159.9,151.4,136.8,119.8,110.9,109.4,89.0$, 56.2, 13.8. IR (neat) 2170, 1560, $1527 \mathrm{~cm}^{-1}$.

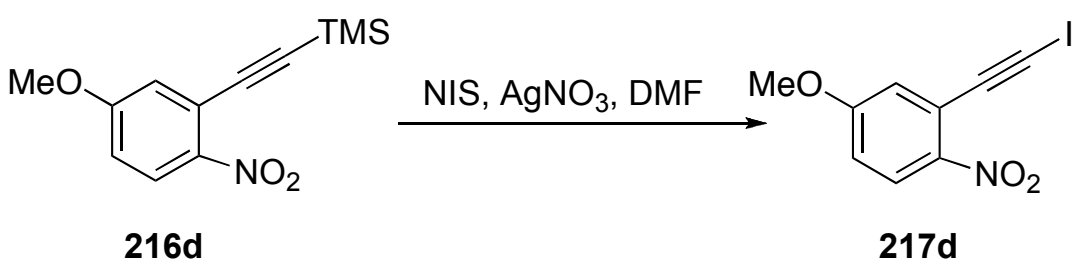

\section{5-Methoxy -2-nitro-1-[2-iodoethynyl]benzene (217d):}

Reaction between $216 \mathrm{~d}(300 \mathrm{mg}, 1.27 \mathrm{mmol})$ and NIS (318 mg, $1.41 \mathrm{mmol})$ in presence of silver nitrate (122 mg, $0.658 \mathrm{mmol})$ in anhydrous DMF (2 ml) as described above for 212a (1 $\mathrm{h})$ afforded the product $\mathbf{2 1 7} \mathbf{d}^{138}(299 \mathrm{mg}, 0.987 \mathrm{mmol}, 77 \%)$ as a pale yellow solid after work up and chromatography (hexanes/EtOAc, 8:2). Mp 87-88 ${ }^{\circ} \mathrm{C} ;{ }^{1} \mathrm{H}$ NMR $\left(270 \mathrm{MHz}, \mathrm{CDCl}_{3}\right): \delta 8.09$ (d, J=9.1 Hz, 1H), 7.07 (d, J=2.7 Hz, 1H), 6.93 (dd, J=9.3, 2.8 $\mathrm{Hz}, 1 \mathrm{H}), 3.89$ (s, 3H); ${ }^{13} \mathrm{C}$ NMR $\left(67.5 \mathrm{MHz}, \mathrm{CDCl}_{3}\right)^{136}: \delta$ 162.8, 143.3, 127.1, 120.8, 119.9, 115.1, 89.5, 56.1, 16.8; IR (neat) 2160, 1606, $1573 \mathrm{~cm}^{-1}$.
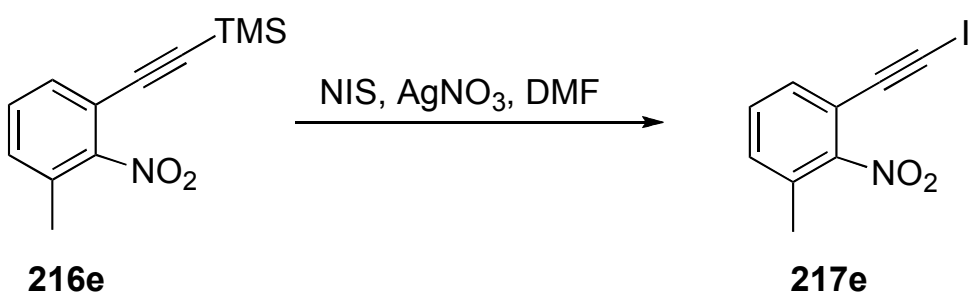

\section{3-Methyl-2-nitro-1-[2-iodoethynyl]benzene (217e):}

Reaction between $216 \mathrm{e}(175 \mathrm{mg}, 0.751 \mathrm{mmol})$ and NIS (189 mg, $0.838 \mathrm{mmol})$ in presence of silver nitrate $(135 \mathrm{mg}, 0.771 \mathrm{mmol})$ in anhydrous DMF $(5 \mathrm{ml})$ as described above for $212 \mathrm{a}(20 \mathrm{~min})$ afforded the product $217 \mathrm{e}(200 \mathrm{mg}, 0.697 \mathrm{mmol}, 93 \%)$ as a 
yellow solid after work up. The product decomposes upon standing at room temperature and on attempted purification on silical gel. ${ }^{1} \mathrm{H}$ NMR $\left(600 \mathrm{MHz}, \mathrm{CDCl}_{3}\right): \delta 7.39$ (d, J=7.8 $\mathrm{Hz}, 1 \mathrm{H}), 7.33(\mathrm{t}, \mathrm{J}=7.8 \mathrm{~Hz}, 1 \mathrm{H}), 7.26(\mathrm{~d}, \mathrm{~J}=7.5 \mathrm{~Hz}, 1 \mathrm{H}) ;{ }^{13} \mathrm{C} \mathrm{NMR}\left(67.5 \mathrm{MHz}, \mathrm{CDCl}_{3}\right)^{136}$ : ठ 153.6, 131.9, 130.5, 130.1, 116.8, 87.6, 17.8, 14.9;

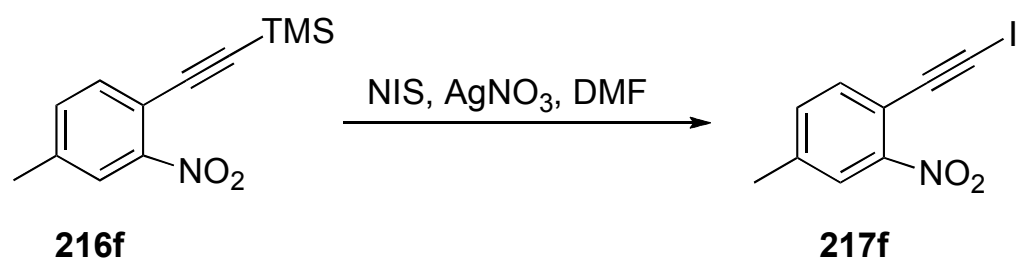

\section{4-Methyl-2-nitro-1-[2-iodoethynyl]benzene (217f):}

Reaction between $216 f^{96}(715 \mathrm{mg}, 0.751 \mathrm{mmol})$ and NIS (768 mg, $\left.3.404 \mathrm{mmol}\right)$ in presence of silver nitrate ( $58 \mathrm{mg}, 0.108 \mathrm{mmol})$ in anhydrous DMF $(5 \mathrm{ml})$ as described above for $\mathbf{2 1 2 a}(1 \mathrm{~h})$ afforded the product $\mathbf{2 1 7 f}(646 \mathrm{mg}, 2.25 \mathrm{mmol}, 73 \%)$ as a yellow solid ${ }^{138}$ after work up and chromatography (hexanes/EtOAc, 9:1). Mp 94-96 ${ }^{\circ} \mathrm{C} ;{ }^{1} \mathrm{H}$ NMR (600 MHz) ס 7.85 (s, 1 H), 7.51 (d, J=7.8 Hz, 1H), 7.37 (d, J=8.4 Hz, 1 H), 2.44 (s, $3 \mathrm{H}) ;{ }^{13} \mathrm{C}$ NMR $(150 \mathrm{MHz}) \delta 150.5,140.4,135.8,125.1,115.9,89.2,21.5,15.2$.

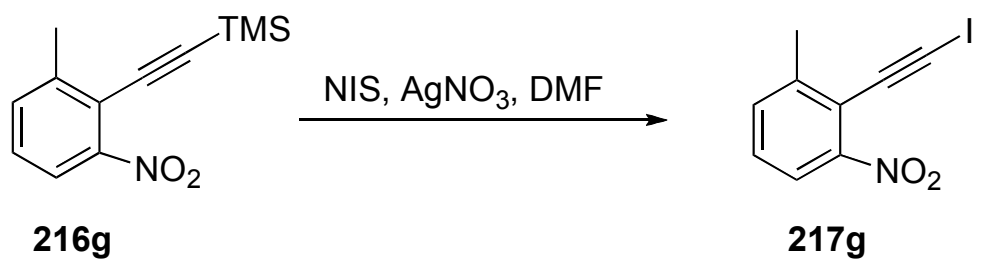

\section{6-Methyl-2-nitro-1-[2-iodoethynyl]benzene (217g):}

Reaction between $\mathbf{2 1 6 g}$ (135 mg, $0.579 \mathrm{mmol})$ and NIS (144 mg, $0.638 \mathrm{mmol})$ in presence of silver nitrate (53 $\mathrm{mg}, 0.303 \mathrm{mmol}$ ) in anhydrous DMF (2 $\mathrm{ml})$ as described above for $212 \mathrm{a}(5.5 \mathrm{~h})$ afforded the product $\mathbf{2 1 7 \mathrm { g }}(155 \mathrm{mg}, 0.54 \mathrm{mmol}, 93 \%)$ as a yellow 
solid after work up and chromatography (hexanes/EtOAc, 9:1). Mp 87-88 ${ }^{\circ} \mathrm{C} .{ }^{1} \mathrm{H}$ NMR (600 MHz) $\delta 7.81$ (d, J=8.4 Hz, 1 H), 7.48 (d, J=7.8 Hz, 1H), 7.33 (t, J=8.1 Hz, 1 H), $2.53(\mathrm{~s}, 3 \mathrm{H}) ;{ }^{13} \mathrm{C}$ NMR $(150 \mathrm{MHz}) \delta 151.6,144.9,134.0,128.4,122.1,118.1,87.8,21.3$, 20.5. IR (neat) $2928,2169 \mathrm{~cm}^{-1}$.

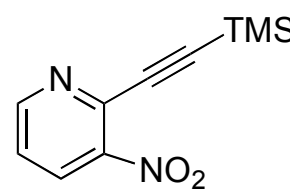

219
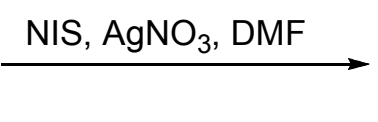

2-(3-Nitropyridyl)-1-iodoethyne (220):

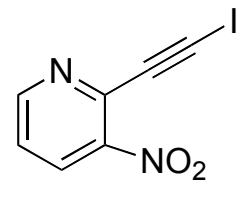

220

To a solution of 219 ( $55 \mathrm{mg}, 0.28 \mathrm{mmol}$ ) in $5 \mathrm{ml}$ anhydrous DMF, cooled in ice, silver nitrate $(6 \mathrm{mg}, 0.035 \mathrm{mmol})$ and NIS $(75 \mathrm{mg}, 0.332 \mathrm{mmol})$ are added and the mixture was slowly allowed to warm up to room temperature. The reaction flask was covered with an aluminium foil and the mixture was stirred under nitrogen for $21 \mathrm{~h}$. Work up and chromatography (hexanes/EtOAc, 7:3) as described for 212a gave the product $\mathbf{2 2 0}$ (53 $\mathrm{mg}, 0.193 \mathrm{mmol}, 69 \%)$ as a yellow solid. Mp $162-164{ }^{\circ} \mathrm{C} ;{ }^{1} \mathrm{H}$ NMR $(600 \mathrm{MHz}) \delta 8.81$ (dd, J=4.8, 1.2 Hz, 1H), 8.36 (dd, J=8.4, $1.8 \mathrm{~Hz}, 1 \mathrm{H}), 7.46$ (dd, J=8.4, $4.8 \mathrm{~Hz}, 1 \mathrm{H}$ ); ${ }^{13} \mathrm{C}$ NMR $(150 \mathrm{MHz}) \delta 153.6,147.7,136.9,132.6,123.5,89.9,21.2 . \mathrm{IR}$ (neat) 1593, 1520, 1339, 819, $759 \mathrm{~cm}^{-1}$. Anal. calcd. for $\mathrm{C}_{7} \mathrm{H}_{4} \mathrm{IN}_{2} \mathrm{O}_{2}$ : C, 30.68; $\mathrm{H}, 1.10 ; \mathrm{N}, 10.22$. Found $\mathrm{C}$, 30.93; $\mathrm{H}, 1.24 ; \mathrm{N}, 9.73$. HRMS calcd for $\mathrm{C}_{7} \mathrm{H}_{4} \mathrm{IN}_{2} \mathrm{O}_{2} \mathrm{M}+\mathrm{H}^{+}$274.9318, found 274.9312. 


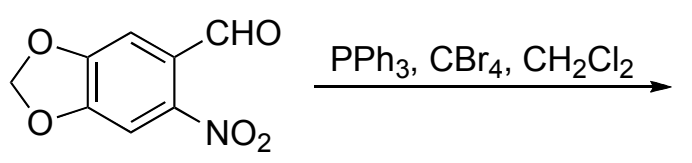

221<smiles>O=[N+]([O-])c1cc2c(cc1C=C(Br)Br)OCO2</smiles>

222

\section{5-(2,2-Dibromoethen-1-yl)-6-nitrobenzo[1,3]dioxole (222):}

A solution of carbon tetrabromide $(679 \mathrm{mg}, 2.05 \mathrm{mmol})$ in dichloromethane $(25 \mathrm{ml})$ was cooled in an ice bath at $0^{\circ} \mathrm{C}$. Triphenylphosphine $(1.074 \mathrm{gm}, 4.1 \mathrm{mmol})$ was added in portions in 10 minute intervals followed by the addition of 6-nitropiperonal (221) (200 $\mathrm{mg}, 1.025 \mathrm{mmol})$. The resulting wine red mixture was allowed to warm to room temperature, and stirred under an atmosphere of nitrogen for 18 hours. The solvent was removed under reduced pressure, and the orange crude was purified quickly by flash chromatography (hexanes/EtOAc, 8:2) due to the observed gradual decomposition of the product on silica. The product, $222(273 \mathrm{mg}, 0.778 \mathrm{mmol}, 76 \%)$ was obtained as an yellow crystalline solid. Mp 158-160 ${ }^{\circ} \mathrm{C} ;{ }^{1} \mathrm{H}$ NMR $(600 \mathrm{MHz}) \delta 7.71(\mathrm{~s}, 1 \mathrm{H}), 7.63(\mathrm{~s}, 1 \mathrm{H})$, 6.95 (s, 1H), 6.16 (s, 2H); ${ }^{13} \mathrm{C}$ NMR $(150 \mathrm{MHz}) \delta 151.9,148.2,141.3,134.5,128.0$, 110.1, 105.5, 103.3, 92.6; IR (neat) 1503, 1483, 1318, 1028, $830 \mathrm{~cm}^{-1}$; HRMS calcd for $\mathrm{C}_{9} \mathrm{H}_{6} \mathrm{Br}_{2} \mathrm{NO}_{4}\left(\mathrm{M}+\mathrm{H}^{+}\right) 349.8664$, found 349.8658 .

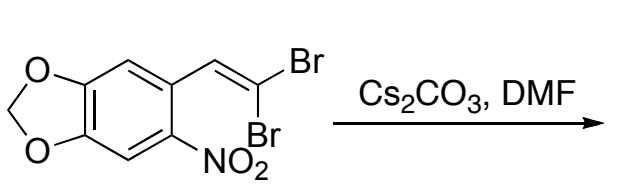

222

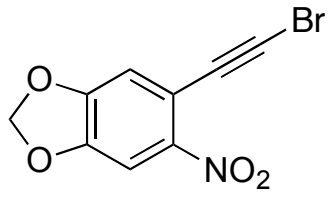

223

\section{5-(2-Bromomoethyny-1-yl)-6-nitrobenzo[1,3]dioxole (223):}

To a solution of 222 (105 mg, $0.299 \mathrm{mmol}$ ) prepared in DMF (3 ml), crushed and oven dried $\mathrm{Cs}_{2} \mathrm{CO}_{3}(283 \mathrm{mg}, 2.99 \mathrm{mmol})$ was added and the resulting mixture was stirred at room temperature under an inert atmosphere $(4 \mathrm{~h})$. Dichloromethane $(50 \mathrm{ml})$ was then 
added followed by water $(25 \mathrm{ml})$. The dichloromethane layer was extracted, washed with water $(2 \times 50 \mathrm{ml})$, dried (anhydrous $\left.\mathrm{MgSO}_{4}\right)$, filtered and evaporated under reduced pressure to leave an yellow crude which was purified by flash chromatography (hexanes/ EtOAc, 85:15). The product $\mathbf{2 2 3}$ was obtained as an yellow solid in an almost quantitative yield (80 mg, $0.296 \mathrm{mmol}, 99 \%) . \mathrm{Mp} 110-112^{\circ} \mathrm{C} ;{ }^{1} \mathrm{H} \mathrm{NMR}(600 \mathrm{MHz}) \delta 7.55$ (s, 1H), $6.98(\mathrm{~s}, 1 \mathrm{H}), 6.14(\mathrm{~s}, 2 \mathrm{H}) ;{ }^{13} \mathrm{C}$ NMR $(150 \mathrm{MHz}) \delta$ 151.8, 148.5, 114.2, 113.5, 105.7, 103.6, 75.9, 57.9; IR (neat) $1603 \mathrm{~cm}^{-1}$; Anal. calcd. for $\mathrm{C}_{9} \mathrm{H}_{4} \mathrm{BrNO}_{4}: \mathrm{C}, 40.03 ; \mathrm{H}$ 1.49; N, 5.19. Found: C 40.09; H 1.61; N, 4.93.

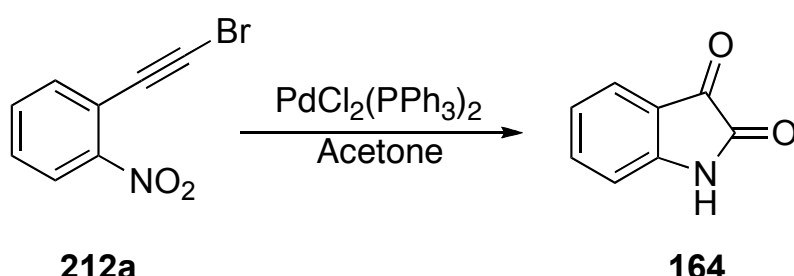

1H-Indole-2,3-dione $(164)^{136}$ :

To a solution of 212a (104 mg, $0.460 \mathrm{mmol})$ in acetone $(10 \mathrm{ml}), \mathrm{PdCl}_{2}\left(\mathrm{PPh}_{3}\right)_{2}(24 \mathrm{mg}$, $0.0342 \mathrm{mmol}$ ) was added and the resulting mixture was stirred under an atmosphere of nitrogen at room temperature. After 22 hours, the solvent was removed under reduced pressure, and the crude residue was purified by chromatography (hexanes/EtOAc, 7:3) to give the product 164 (22 $\mathrm{mg}, 0.165 \mathrm{mmol}, 36 \%)$ as a red solid. Mp 195-197 으 (lit..137 mp 197-198 C). 


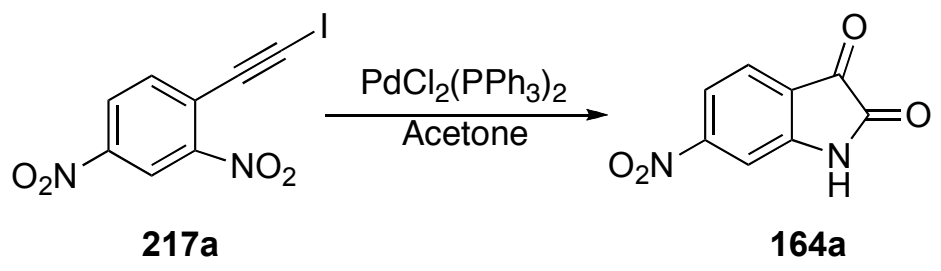

\section{6-Nitroisatin (6-Nitroindole-2,3-dione) (164a):}

The reaction between $217 \mathrm{a}(140 \mathrm{mg}, 0.44 \mathrm{mmol})$ and $\mathrm{PdCl}_{2}\left(\mathrm{PPh}_{3}\right)_{2}(16 \mathrm{mg}, 0.023$ $\mathrm{mmol}$ ) in acetone $(6 \mathrm{ml})$, as described for 164 (room temperature, $6 \mathrm{~h}$ ), afforded the product 164a (25 mg, $0.208 \mathrm{mmol}$ ) after chromatography (hexanes/ EtOAc, 6:4) as a yellow solid. Mp $268^{\circ} \mathrm{C}$ (decomposed) (lit. $\left.{ }^{84} 288-290{ }^{\circ} \mathrm{C}\right) ;{ }^{1} \mathrm{H}$ NMR $(600 \mathrm{MHz}$, DMSOd6) $\delta 11.35$ (br s, 1H), 7.86 (dd, J=7.8, $1.8 \mathrm{~Hz}, 1 \mathrm{H}), 7.54$ (d, J=1.8 Hz, 1H); ${ }^{13} \mathrm{C}$ NMR $(150 \mathrm{MHz}) \delta 183.1,158.8,152.5,150.7,125.4,122.4,117.7,106.3$.

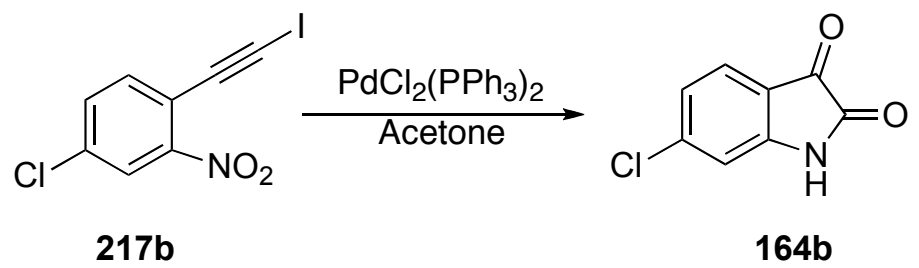

\section{6-Chloroisatin (6-Chloroindole-2,3-dione) (164b):}

The reaction between $217 \mathrm{~b}$ (50 mg, $0.163 \mathrm{mmol})$ and $\mathrm{PdCl}_{2}\left(\mathrm{PPh}_{3}\right)_{2}(15 \mathrm{mg}, 0.021$ $\mathrm{mmol}$ ) in acetone (10 $\mathrm{ml}$ ), as described for 164 (room temperature, $96 \mathrm{~h}$ ), afforded the product 164b (12 mg, $0.076 \mathrm{mmol}, 47 \%$ ) after chromatography (hexanes/ EtOAc, 7:3) as a yellow solid. Mp $268^{\circ} \mathrm{C}$ (decomposed) (lit. $\left.{ }^{138} 263^{\circ} \mathrm{C}\right) ;{ }^{1} \mathrm{H}$ NMR $(600 \mathrm{MHz}$, DMSO$\left.\mathrm{d}_{6}\right) \delta 11.15(\mathrm{br} \mathrm{s}, 1 \mathrm{H}), 7.52(\mathrm{~d}, J=7.8 \mathrm{~Hz}, 1 \mathrm{H}), 7.11(\mathrm{dd}, J=8.4,1.8 \mathrm{~Hz}, 1 \mathrm{H}) ;{ }^{13} \mathrm{C}$ NMR (150 MHz) ठ 183.6, 160.1, 152.5, 142.9, 126.9, 123.4, 117.4, 112.8. 


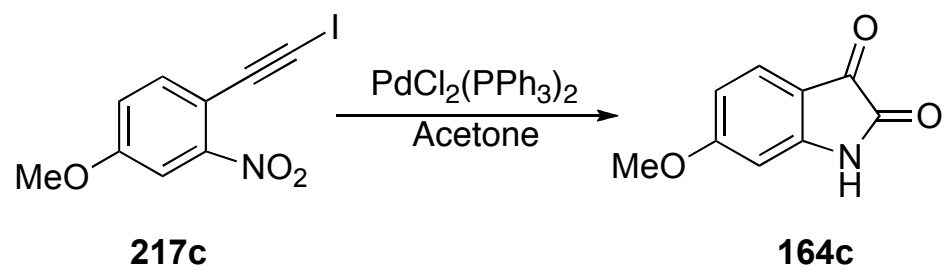

6-Methoxyisatin (6-methoxyindole-2,3-dione) ${ }^{139}$ (164c):

The reaction between $217 \mathrm{c}(90 \mathrm{mg}, 0.297 \mathrm{mmol})$ and $\mathrm{PdCl}_{2}\left(\mathrm{PPh}_{3}\right)_{2}(12 \mathrm{mg}, 0.017$ $\mathrm{mmol}$ ) in acetone $(10 \mathrm{ml}$ ), as described for 164 (room temperature, $48 \mathrm{~h}$ ), afforded the product 164c (31 mg, $0.175 \mathrm{mmol}, 59 \%$ ) after chromatography (hexanes/ EtOAc, 1:1) as a yellow solid. Mp $220^{\circ} \mathrm{C}$ (decomposed) (lit. $\left.{ }^{140} 229-230{ }^{\circ} \mathrm{C}\right) ;{ }^{1} \mathrm{H}$ NMR $(600 \mathrm{MHz})$ (DMSO-d 6 ): $\delta 10.95$ (s, 1H), 7.49 (d, J= $8.4 \mathrm{~Hz}, 1 \mathrm{H}$ ), 6.59 (dd, J=8.4, 2.4 Hz, 1H), 6.40 (d, J=2.4 Hz, 1H), 3.87 (s, 3H); ${ }^{13} \mathrm{C}$ NMR (150 MHz): $\delta 181.5,167.7,160.5,153.5$, 127.3, 111.1, 108.8, 97.8, 56.1.

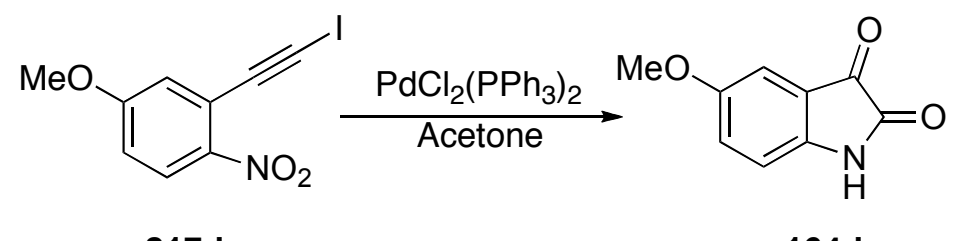

217d

$164 d$

5-Methoxyisatin (5-methoxyindole-2,3-dione) ${ }^{141}$ (164d):

The reaction between $217 \mathbf{d}(290 \mathrm{mg}, 0.957 \mathrm{mmol})$ and $\mathrm{PdCl}_{2}\left(\mathrm{PPh}_{3}\right)_{2}(35 \mathrm{mg}, 0.049$ $\mathrm{mmol}$ ) in acetone $(10 \mathrm{ml}$ ), as described for 164 (room temperature, $36 \mathrm{~h}$ ), afforded the product 164d (103 mg, $0.581 \mathrm{mmol}, 61 \%$ ) after chromatography (hexanes/ EtOAc, 6:4) as a dark red solid. Mp 190-195 ${ }^{\circ} \mathrm{C}\left(\right.$ lit $\left.^{142,140} \mathrm{mp} 200-201^{\circ} \mathrm{C}\right) ;{ }^{1} \mathrm{H}$ NMR $(270 \mathrm{MHz})$ (DMSO-d 6 ): $\delta 10.85$ (s, 1H), 7.19-7.15 (dd, J=8.6 Hz, 8.4 Hz, 1H), 7.05 (dd, J=2.4 Hz, 1H), 6.84 (d, J=8.6 Hz, 1H), $3.73(\mathrm{~s}, 3 \mathrm{H}) ;{ }^{13} \mathrm{C}$ NMR (67.5 MHz): $\delta 184.8,159.7,155.4$, $144.7,125.0,118.2,113.4,108.9,55.9$. 

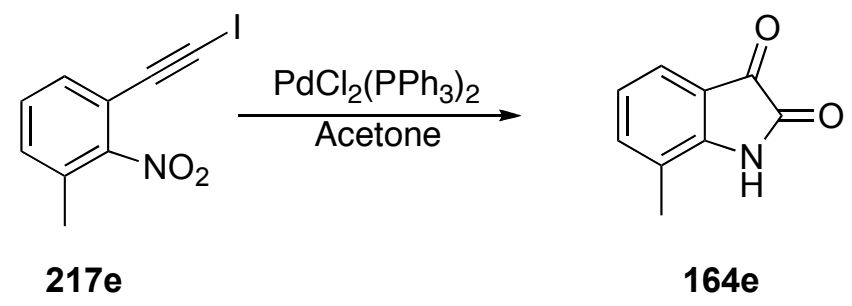

7-Methylisatin (7-methylindole-2,3-dione) (164e):

The reaction between $217 \mathrm{e}(170 \mathrm{mg}, 0.592 \mathrm{mmol})$ and $\mathrm{PdCl}_{2}\left(\mathrm{PPh}_{3}\right)_{2}(22 \mathrm{mg}, 0.031$ $\mathrm{mmol}$ ) in acetone $(10 \mathrm{ml}$ ), as described for 164 (room temperature, $30 \mathrm{~h}$ ), afforded the product $164 \mathrm{e}(67 \mathrm{mg}, 0.416 \mathrm{mmol}, 70 \%)$ after chromatography (hexanes/EtOAc, 6:4) as an orange solid. Mp 265-268 ${ }^{\circ} \mathrm{C}$ (lit $\left.{ }^{144,145} 267-269{ }^{\circ} \mathrm{C}\right) ;{ }^{1} \mathrm{H}$ NMR $(600 \mathrm{MHz})\left(\mathrm{DMSO}-\mathrm{d}_{6}\right)$ : ठ 11.06 (br s, 1H), $7.42(\mathrm{~d}, J=7.8 \mathrm{~Hz}, 1 \mathrm{H}), 7.33(\mathrm{~d}, J=7.2 \mathrm{~Hz}, 1 \mathrm{H}), 6.98(\mathrm{t}, J=7.8 \mathrm{~Hz}, 1 \mathrm{H})$, 2.19 (s, 3H); ${ }^{13} \mathrm{C}$ NMR (125 MHz): $\delta$ 184.7, 150.9, 149.2, 139.4, 122.6, 121.9, 121.5, $117.5,15.4$

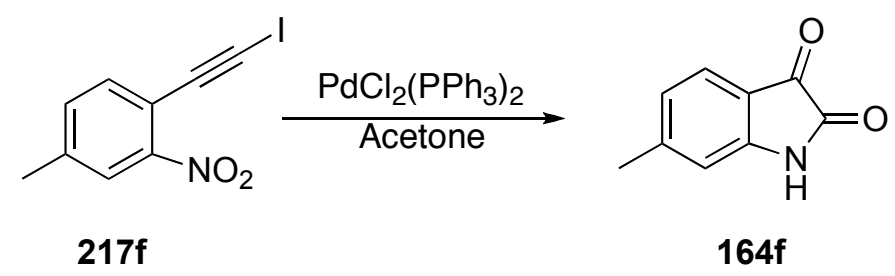

\section{6-Methylisatin (6-methylindole-2,3-dione) ${ }^{143}$ (164f):}

The reaction between $217 \mathrm{f}(165 \mathrm{mg}, 0.575 \mathrm{mmol})$ and $\mathrm{PdCl}_{2}\left(\mathrm{PPh}_{3}\right)_{2}(22 \mathrm{mg}, 0.031$ $\mathrm{mmol}$ ) in acetone $(10 \mathrm{ml}$ ), as described for 164 (room temperature, $36 \mathrm{~h}$ ), afforded the product $164 \mathrm{f}$ (57 mg, $0.342 \mathrm{mmol}, 59 \%$ ) after chromatography (hexanes/EtOAc, 6:4) as an orange-red solid. Mp $182-184^{\circ} \mathrm{C}\left(\right.$ lit $\left.^{146} 187-189{ }^{\circ} \mathrm{C}\right) ;{ }^{1} \mathrm{H}$ NMR $(600 \mathrm{MHz})\left(\mathrm{DMSO}-\mathrm{d}_{6}\right)$ : $\delta 10.97$ (br s, 1H), 7.39 (d, J=7.8 Hz, 1H), 6.88 (dd, J=7.8 Hz \& 1.2 Hz, 1H), 6.72 (d, 
$J=0.6 \mathrm{~Hz}, 1 \mathrm{H}), 2.35$ (s, 3H); ${ }^{13} \mathrm{C}$ NMR $(125 \mathrm{MHz}): \delta$ 183.6, 159.8, 151.1, 150.1, 124.7 , $123.5,115.5,112.6,22.2$.

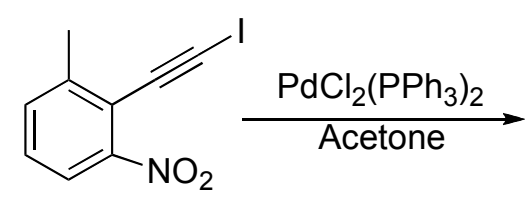

$217 \mathrm{~g}$<smiles>Cc1cccc2c1C(=O)C(=O)N2</smiles>

$164 \mathrm{~g}$

\section{4-Methylisatin (4-methylindole-2,3-dione) (164g):}

The reaction between $\mathbf{2 1 7 g}(115 \mathrm{mg}, 0.40 \mathrm{mmol})$ and $\mathrm{PdCl}_{2}\left(\mathrm{PPh}_{3}\right)_{2}(14 \mathrm{mg}, 0.02 \mathrm{mmol})$ in acetone (10 ml), as described for 164 (room temperature, $20 \mathrm{~h}$ ), gave $164 \mathrm{~g}$ (22 $\mathrm{mg}$, $0.137 \mathrm{mmol}, 34 \%$ ) as the product after chromatography (hexanes/EtOAc, $7: 3$ ), as an orange solid. Mp 182-184 ${ }^{\circ} \mathrm{C}\left(\mathrm{lit}^{144} 186-187^{\circ} \mathrm{C}\right) ;{ }^{1} \mathrm{H}$ NMR $(600 \mathrm{MHz})\left(\mathrm{CDCl}_{3}\right): \delta 8.13(\mathrm{br}$ s, 1H), 7.40 (t, J=7.8 Hz, 1H), 6.89 (d, J=7.2 Hz, 1H), 6.71 (d, J=7.8 Hz, 1H), 2.57 (s, $3 \mathrm{H}) ;{ }^{13} \mathrm{C}$ NMR (125 MHz): $\delta$ 183.5, 159.3, 149.2, 141.9, 138.1, 126.4, 116.7, 109.6, 18.3.

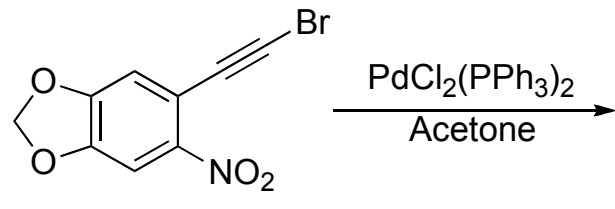

223<smiles>O=C1Nc2cc3c(cc2C1=O)OCO3</smiles>

224

5H-[1,3]Dioxalo[4,5-f]indole-6,7-dione (224) ${ }^{145}$ :

The reaction between $223(80 \mathrm{mg}, 0.296 \mathrm{mmol})$ and $\mathrm{PdCl}_{2}\left(\mathrm{PPh}_{3}\right)_{2}(10 \mathrm{mg}, 0.014 \mathrm{mmol})$ in acetone $(6 \mathrm{ml})$, as described for 164 (room temperature, $5 \mathrm{~h}$ ), afforded the product 224 (20 mg, $0.105 \mathrm{mmol}, 35 \%$ ) after chromatography (hexanes/EtOAc, 1:1) as a pink solid. Mp 280-281 ${ }^{\circ} \mathrm{C}\left(\mathrm{lit}^{146} 284^{\circ} \mathrm{C}\right) ;{ }^{1} \mathrm{H}$ NMR $(600 \mathrm{MHz}): \delta 10.76(\mathrm{~s}, 1 \mathrm{H}), 7.05(\mathrm{~s}, 1 \mathrm{H})$, 
$6.55(\mathrm{~s}, 1 \mathrm{H}), 6.13$ (s, 2H); ${ }^{13} \mathrm{C}$ NMR (150 MHz): $\delta$ 181.3, 160.3, 156.1, 150.4, 143.6, 110.0, 103.8, 102.5, 94.6.

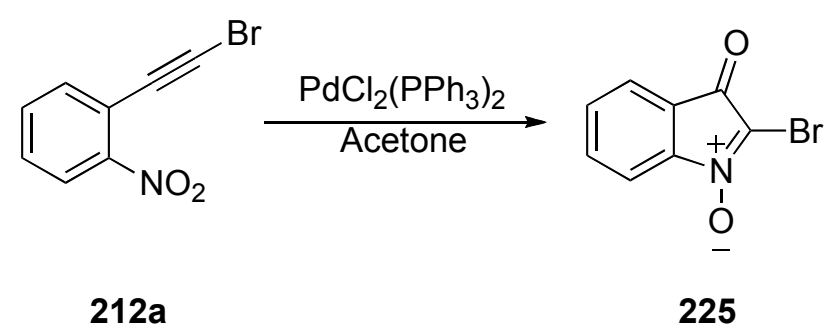

\section{2-Bromo-3-oxo-3H-indole-1-oxide (225):}

To a solution of $212 \mathrm{a}(235 \mathrm{mg}, 1.03 \mathrm{mmol})$ in $\mathrm{CH}_{2} \mathrm{Cl}_{2}(25 \mathrm{ml}), \mathrm{PdCl}_{2}\left(\mathrm{PPh}_{3}\right)_{2}(77 \mathrm{mg}$, $0.109 \mathrm{mmol}$ ) was added and the reaction mixture was heated to reflux for 80 minutes. The solvent was removed under reduced pressure and the resulting crude was purified by chromatography (hexanes/EtOAc, 6:4) to yield the product 225 (230 mg, 1.017 mmol, 99\%) as an orange solid. ${ }^{1} \mathrm{H}$ NMR $(270 \mathrm{MHz}): \delta 7.74-7.55(\mathrm{~m}, 4 \mathrm{H}) ;{ }^{13} \mathrm{C}$ NMR (67.5 MHz): $\delta 180.5,147.8,135.1,135.0,131.6,131.5,123.0,122.3,114.0 ;$ IR (ATR) $1735,1652,1506 \mathrm{~cm}^{-1}$.

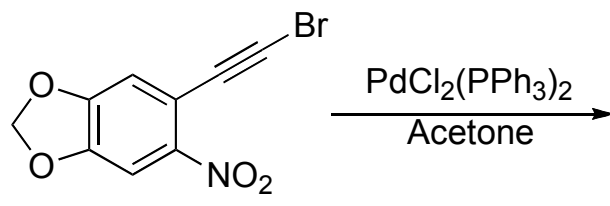

223<smiles>O=C1C(Br)=[N+]([O-])c2cc3c(cc21)OCO3</smiles>

248

\section{6-Bromo-7-oxo-7H-[1,3]dioxalo[4,5-f]indole-5-oxide (248):}

To a solution of $223(28 \mathrm{mg}, 0.104 \mathrm{mmol})$ in acetone $(5 \mathrm{ml}), \mathrm{PdCl}_{2}\left(\mathrm{PPh}_{3}\right)_{2}(4 \mathrm{mg}, 0.006$ $\mathrm{mmol}$ ) was added and the reaction mixture was allowed to stir at room temperature for 
50 minutes. The solvent was removed under reduced pressure and the resulting crude was purified by chromatography (hexanes/EtOAc, 6:4) to yield the product 248 (24 mg, $0.089 \mathrm{mmol}, 86 \%)$ as a brown solid. Further elution afforded a trace amount of the isatin 224. Mp $125^{\circ} \mathrm{C}$ (decomposed); ${ }^{1} \mathrm{H}$ NMR $(600 \mathrm{MHz}) \delta 7.17$ (s,1H), 7.05 (s, 1H), 6.17 (s, $2 \mathrm{H}) ;{ }^{13} \mathrm{C}$ NMR $(150 \mathrm{MHz}) \delta 179.7,153.1,150.1,144.7,117.4,117.1,103.6,103.3,97.8$; IR (ATR) 1717, 1500, 1292, $1031 \mathrm{~cm}^{-1}$; HRMS (ESI) calcd for $\mathrm{C}_{9} \mathrm{H}_{5} \mathrm{BrNO}_{4}\left(\mathrm{M}+\mathrm{H}^{+}\right)$ 269.9402, found 269.9399 .

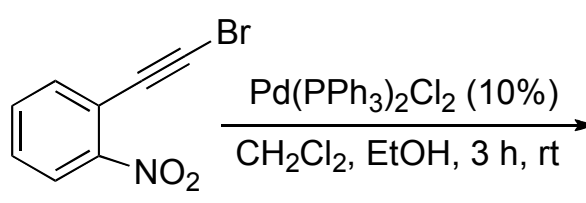

212a<smiles>CCOC1C(=O)c2ccccc2[N+]1[O-]</smiles>

$250 a$

\section{2-Ethoxyisatogen (250a):}

To a solution of $212 \mathrm{a}(50 \mathrm{mg}, 0.221 \mathrm{mmol})$ in $\mathrm{DCM}(5 \mathrm{ml}), \mathrm{PdCl}_{2}\left(\mathrm{PPh}_{3}\right)_{2}(12 \mathrm{mg}, 0.017$ $\mathrm{mmol})$ and $\mathrm{EtOH}(0.5 \mathrm{ml})$ was added and the reaction mixture was heated at $45^{\circ} \mathrm{C}(3 \mathrm{~h})$ under an inert atmosphere. The solvent was removed under reduced pressure and the resulting crude was purified by chromatography (hexanes/EtOAc, 7:3) to yield the product $250 \mathrm{a}$ (30 mg, $0.156 \mathrm{mmol}, 70 \%)$ as an yellow solid. Mp $45-47{ }^{\circ} \mathrm{C} ;{ }^{1} \mathrm{H}$ NMR $(600$ MHz) $\delta 7.92(\mathrm{~d}, J=8.4 \mathrm{~Hz}, 1 \mathrm{H}), 7.71(\mathrm{~d}, J=9 \mathrm{~Hz}, 1 \mathrm{H}), 7.38(\mathrm{dt}, J=9,2.4 \mathrm{~Hz}, 1 \mathrm{H}), 7.23(\mathrm{dt}$, $J=8.4,2.4 \mathrm{~Hz}, 1 \mathrm{H}), 4.54$ (q, 2H), 1.49 (t, 3H); ${ }^{13} \mathrm{C}$ NMR (150 MHz) $\delta$ 157.7, 157.3, 153.9, 131.3, 127.9, 120.7, 120.5, 116.3, 62.4, 14.5; IR (neat) 1726, 1304, 1224, 1178 $\mathrm{cm}^{-1}$. 


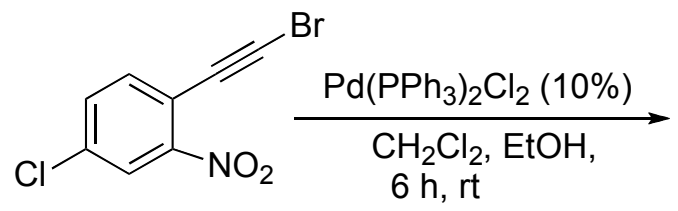

212c<smiles>CCOC1C(=O)c2ccc(Cl)cc2[N+]1[O-]</smiles>

250c

\section{6-Chloro-2-ethoxyisatogen (250c):}

To a solution of $212 \mathrm{c}(132 \mathrm{mg}, 0.43 \mathrm{mmol})$ in $\mathrm{DCM}(20 \mathrm{ml}), \mathrm{PdCl}_{2}\left(\mathrm{PPh}_{3}\right)_{2}(35 \mathrm{mg}, 0.05$ $\mathrm{mmol})$ and $\mathrm{EtOH}(0.5 \mathrm{ml})$ was added and the reaction mixture was stirred at room temperature $(6 \mathrm{~h})$ under an inert atmosphere. The solvent was removed under reduced pressure and the resulting crude was purified by chromatography (hexanes/EtOAc, 8:2) to yield the product $250 \mathrm{c}(25 \mathrm{mg}, 0.09 \mathrm{mmol}, 23 \%)$ as a pale orange solid.

Mp 74-75 ㅇ; ${ }^{1} \mathrm{H}$ NMR $(600 \mathrm{MHz}) \delta 7.89(\mathrm{dd}, J=9,0.6 \mathrm{~Hz}, 1 \mathrm{H}), 7.72(\mathrm{dd}, J=1.8,0.6 \mathrm{~Hz}$, 1H), $7.17(\mathrm{dd}, J=9,1.8 \mathrm{~Hz}, 1 \mathrm{H}), 4.55(\mathrm{q}, 2 \mathrm{H}), 1.49(\mathrm{t}, 3 \mathrm{H}) ;{ }^{13} \mathrm{C}$ NMR $(150 \mathrm{MHz}) \delta$ 157.8, 156.9, 154.6, 137.9, 130.0, 122.1, 118.9, 114.8, 62.7, 14.4; IR (neat) 1737, $1218,1198 \mathrm{~cm}^{-1}$.<smiles>O=C1C(Br)=[N+]([O-])c2ccccc21</smiles>

225
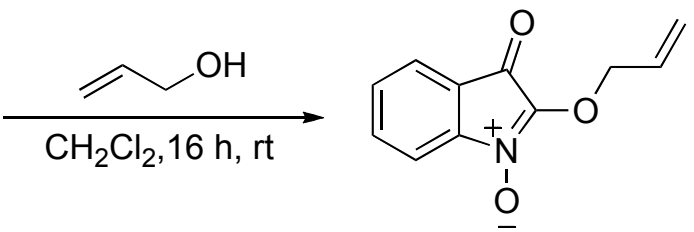

251

\section{2-Allyloxyisatogen (251):}

To a solution of $225(149 \mathrm{mg}, 0.66 \mathrm{mmol})$ in dichloromethane $(10 \mathrm{ml})$, allyl alcohol (200mg, $3.46 \mathrm{mmol}$ ) was added and the reaction mixture was stirred at room temperature $(16 \mathrm{~h})$ under an inert atmosphere. The solvent was removed under reduced 
pressure and the resulting crude was purified by chromatography (hexanes/EtOAc, 9:1) to yield the product 251 ( $50 \mathrm{mg}, 0.25 \mathrm{mmol}, 38 \%$ ) as a pale brown solid. Mp $33-35^{\circ} \mathrm{C}$; ${ }^{1} \mathrm{H}$ NMR $(600 \mathrm{MHz}) \delta 7.93$ (ddd, J=8.8, 0.8, 0.8 Hz, 1H), 7.72 (ddd, J=9.1, 0.9, 0.8 Hz, 1H), 7.39 (ddd, J=9.1, 6.4, 0.6 Hz, 1H), 7.25 (ddd, J=8.8, 6.4, $0.9 \mathrm{~Hz}, 1 \mathrm{H}$ ), 6.09 (ddt, $J=17.2,10.5,5.9 \mathrm{~Hz}, 1 \mathrm{H}), 5.51(\mathrm{dq}, J=17.2,1.3 \mathrm{~Hz}, 1 \mathrm{H}), 5.38(\mathrm{dq}, J=10.5,1.3 \mathrm{~Hz}, 1 \mathrm{H})$, $4.98(\mathrm{dt}, \mathrm{J}=5.9,1.3 \mathrm{~Hz}, 1 \mathrm{H}) ;{ }^{13} \mathrm{C}$ NMR $(150 \mathrm{MHz}) \delta$ 157.5, 156.8, 153.5, 131.2, 131.1, 127.9, 120.5, 120.4, 119.8, 116.2, 66.5; IR (neat) 1719, 1306, $1195 \mathrm{~cm}^{-1}$; HRMS Calcd for $\mathrm{C}_{11} \mathrm{H}_{9} \mathrm{NO}_{3}\left(\mathrm{M}+\mathrm{H}^{+}\right)$204.0660; found 204.0655 .

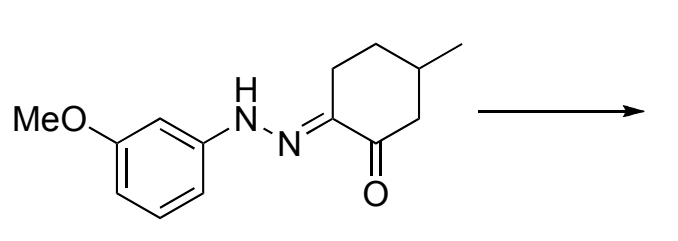

262

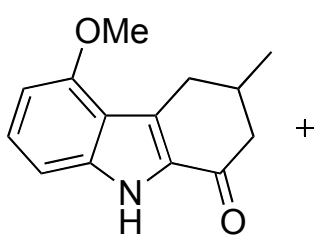

257d

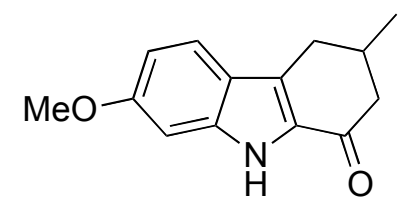

257c

2,3,4,9-Tetrahydro-7-methoxy-3-methyl-1H-carbazol-1-one (257c) and 2,3,4,9tetrahydro-5-methoxy-3-methyl-1H-carbazol-1-one (257d):

The phenyl hydrazone 262 (197 mg, $0.788 \mathrm{mmol}$ ) was dissolved in glacial acetic acid $(1.3 \mathrm{ml})$ and refluxed with Conc. $\mathrm{HCl}(0.4 \mathrm{ml})$ for $5 \mathrm{~min}$. The reaction mixture was diluted with ice water and filtered. The precipitate obtained was purified by chromatographed over a silica column (hexane/EtOAc, 9:1) to afford $257 \mathrm{c}$ (90 $\mathrm{mg}, 0.390 \mathrm{mmol}, 49 \%$ ) as a colorless solid. Mp 204-206 ${ }^{\circ} \mathrm{C}$. (lit ${ }^{116,113 a}$. mp $211^{\circ} \mathrm{C}$ ). Further elution with (hexaneethyl acetate, 7:3) gave $\mathbf{2 5 7 d}$ (13 $\mathrm{mg}, 0.057 \mathrm{mmol}, 7 \%$ ) also as a colorless solid. Mp $198^{\circ} \mathrm{C}\left(\right.$ lit. $\left.{ }^{113 a} \mathrm{mp} 201^{\circ} \mathrm{C}\right)$. 


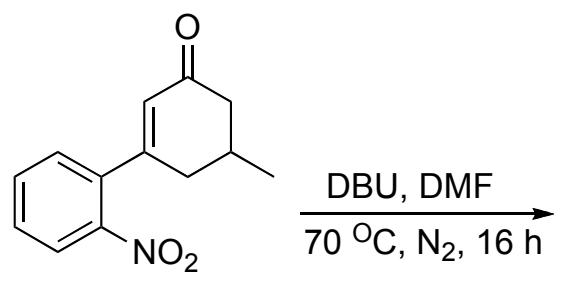

257b

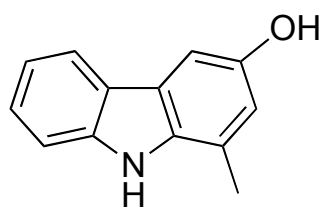

279

\section{1-methyl-3-hydroxycarbazole (279):}

To a solution of compound 257b (105 mg, $0.454 \mathrm{mmol}$ ) in anhydrous DMF (3ml), was added DBU (71 mg, $0.466 \mathrm{mmol}$ ) and heated under an atmosphere of nitrogen for $16 \mathrm{~h}$. The reaction mixture was cooled to room temperature, diluted with water $(20 \mathrm{ml})$, and extracted with dichloromethane $(2 \times 20 \mathrm{ml})$. The organic phase was dried (anhydrous $\mathrm{MgSO}_{4}$ ) and concentrated to give an oily dark crude, that was purified by chromatography (hexanes/EtOAc, 7:3) to yield 279 (25 mg, $0.127 \mathrm{mmol}, 27.8 \%)$ as an off-white solid. Mp 158-160 ${ }^{\circ} \mathrm{C} ;{ }^{1} \mathrm{H}$ NMR $(600 \mathrm{MHz}) \delta 7.96(\mathrm{~d}, \mathrm{~J}=7.8 \mathrm{~Hz}, 1 \mathrm{H}), 7.805$ (br s, 1H), $7.42(\mathrm{~d}, J=7.8 \mathrm{~Hz}, 1 \mathrm{H}), 7.39(\mathrm{t}, \mathrm{J}=7.2 \mathrm{~Hz}, 1 \mathrm{H}), 7.34(\mathrm{~d}, J=1.8 \mathrm{~Hz}, 1 \mathrm{H}), 7.19$ ( t $J=7.8 \mathrm{~Hz}, 1 \mathrm{H}), 6.82(\mathrm{~d}, J=1.8 \mathrm{~Hz}, 1 \mathrm{H}), 4.63(\mathrm{br} \mathrm{s}, 1 \mathrm{H}), 2.51(\mathrm{~s}, 3 \mathrm{H}) ;{ }^{13} \mathrm{C}$ NMR $(150 \mathrm{MHz})$ $\delta 149.5,140.4,134.1,125.9,123.8,123.7,121.0,120.7,119.3,115.8,111.0,103.3 . I R$ (neat) $3149,1492,1373,1172,1061 \mathrm{~cm}^{-1}$; HRMS calcd. for $\mathrm{C}_{13} \mathrm{H}_{12} \mathrm{NO}\left(\mathrm{M}+\mathrm{H}^{+}\right)$ 198.0919, found 198.09134 . 
<smiles>O=C1C=C(c2ccccc2[N+](=O)[O-])CCC1</smiles>

257e

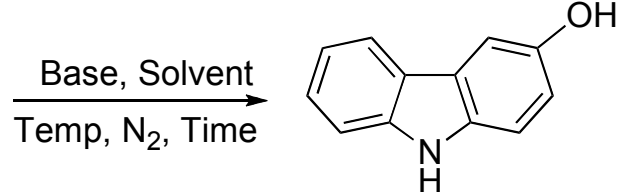

283

3-Hydroxycarbazole (283):

To a solution of compound $257 \mathrm{e}$ (100 $\mathrm{mg}, 0.4603 \mathrm{~mol}$ ) in anhydrous DMF (4 ml) was added DBU (190 mg, $1.248 \mathrm{mmol}$ ) and heated under an atmosphere of nitrogen for $2 \mathrm{~h}$. Work up and purification as described for compound 279, gave 3-hydroxycarbazole (283) (20 mg, $0.109 \mathrm{mmol}, 24 \%$ ) after purification by chromatography (hexane/EtOAc, 7:3) as a colorless solid. ${ }^{147} \mathrm{Mp} 252-255^{\circ} \mathrm{C}\left(\right.$ (lit $\left.^{148} 260-261^{\circ} \mathrm{C}\right)$.

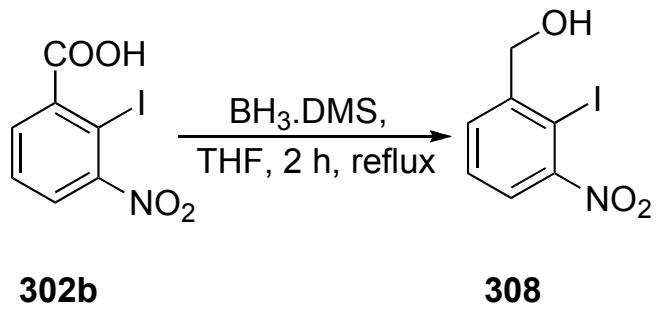

\section{2-lodo-3-nitrobenzylalcohol (308):}

To a solution of 2-iodo-3-nitrobenzoic acid $(2.95 \mathrm{gm}, 0.01 \mathrm{~mol})$ prepared in dry THF (20 $\mathrm{ml})$, was added borane-dimethylsulfide complex $(10 \mathrm{ml}, 2 \mathrm{M})$ slowly with a syringe and the reaction mixture was heated to reflux under an atmosphere of nitrogen for 2 hours. The solution was cooled to room temperature and methanol $(10 \mathrm{ml})$ was added slowly until the bubbles cease, followed by water $(20 \mathrm{ml})$. Extraction of the resulting solution with ethyl acetate $(2 \mathrm{X} 20 \mathrm{ml})$, drying (anhydrous $\left.\mathrm{MgSO}_{4}\right)$ and evaporation of the solvent under reduced pressure gave an yellow solid which was purified by 
chromatography (hexanes/EtOAc, 6:4) to yield $308(2.512 \mathrm{gm}, 0.009 \mathrm{~mol}, 90 \%)$ as a yellow solid. Mp 78-80 ${ }^{\circ} \mathrm{C} ;{ }^{1} \mathrm{H}$ NMR $(600 \mathrm{MHz}) \delta 7.71(\mathrm{dt}, J=7.8,1.6,0.8 \mathrm{~Hz}, 1 \mathrm{H}), 7.58$ (dt, J=7.8, 1.6, 0.5 Hz, 1H), 7.49 (t, J=7.8 Hz, 1H), $4.78(\mathrm{~s}, 2 \mathrm{H}), 2.27(\mathrm{br} \mathrm{s}, 1 \mathrm{H}) ;{ }^{13} \mathrm{C}$ NMR $(150 \mathrm{MHz}) \delta 154.9,146.2,130.8,129.3,123.7,88.4,69.9$.

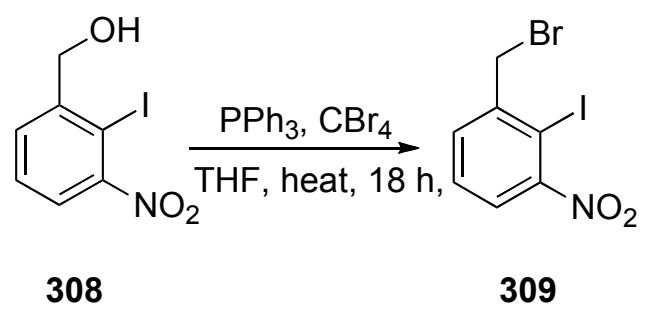

\section{2-iodo-3-nitrobenzylbromide (309):}

2-lodo-3-nitrobenzylalcohol (308) (1.04 gm, $3.728 \mathrm{mmol}$ ), carbon tetrabromide (1.324 $\mathrm{gm}, 3.994 \mathrm{mmol})$ and triphenyl phosphine $(1.05 \mathrm{gm}, 4.003 \mathrm{mmol})$ are taken in an ovendried round-bottomed flask, and dry THF $(20 \mathrm{ml})$ is added with a candula under an inert atmosphere. The resulting reaction mixture is heated to reflux (4 h), cooled to room temperature, and extracted with EtOAc $(2 \times 50 \mathrm{ml})$ after the addition of water $(25 \mathrm{ml})$. The combined organic phases are washed with aq. $\mathrm{NaHSO}_{4}(25 \mathrm{ml})$, dried (anhydrous $\mathrm{MgSO}_{4}$ ) and the solvent is removed under reduced pressure to give an yellow solid, which was purified by chromatography (hexanes/EtOAc, 8:2) to afford 309 (954 mg, $2.79 \mathrm{mmol}, 75 \%)$ as an yellow solid. Mp 65-67 ${ }^{\circ} \mathrm{C} ;{ }^{1} \mathrm{H}$ NMR $(600 \mathrm{MHz}) \delta 7.66$ (dd, $J=7.8,1.8 \mathrm{~Hz}, 1 \mathrm{H}), 7.54(\mathrm{dd}, J=7.8,1.2 \mathrm{~Hz}, 1 \mathrm{H}), 7.46(\mathrm{t}, J=7.2 \mathrm{~Hz}, 1 \mathrm{H}), 4.70(\mathrm{~s}, 2 \mathrm{H}) ;{ }^{13} \mathrm{C}$ NMR (150 MHz) $\delta 156.1,144.0,133.2,129.7,124.3,92.1,38.6$; HRMS calcd. for $\mathrm{C}_{7} \mathrm{H}_{5} \mathrm{BrINO}_{2}\left(\mathrm{M}+\mathrm{H}^{+}\right)$341.8626, found 341.8621 . 


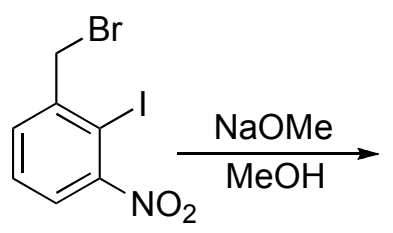

309<smiles>COCc1cccc([N+](=O)[O-])c1I</smiles>

299b

\section{2-iodo-3-nitromethoxytoluene (299b):}

A solution of sodium methoxide, prepared by dissolving sodium (124 mg, $5.391 \mathrm{mmol}$ ) in methanol $(10 \mathrm{ml})$ is added to a methanolic solution of $\mathbf{3 0 9}(925 \mathrm{mg}, 2.705 \mathrm{mmol})$ under an inert atmosphere at $0^{\circ} \mathrm{C}$. The resulting reaction mixture is allowed to stir rapidly at $0{ }^{\circ} \mathrm{C}(4 \mathrm{~h})$. The removal of the solvent under reduced pressure gave an yellow solid, which after purification by chromatography (hexanes/EtOAc, afforded 299b (600 $\mathrm{mg}, 2.047 \mathrm{mmol}, 76 \%)$ as an yellow solid. Mp $26-27^{\circ} \mathrm{C} ;{ }^{1} \mathrm{H}$ NMR $(600 \mathrm{MHz}) \delta 7.63(\mathrm{dd}$, $J=7.2,0.6 \mathrm{~Hz}, 1 \mathrm{H}), 7.55(\mathrm{dt}, J=7.8,0.6 \mathrm{~Hz}, 1 \mathrm{H}), 7.46(\mathrm{t}, J=7.8 \mathrm{~Hz}, 1 \mathrm{H}), 4.503(\mathrm{~s}, 2 \mathrm{H})$; 3.52 (s, 3H); ${ }^{13} \mathrm{C}$ NMR $(150 \mathrm{MHz}) \delta 155.0,144.3,130.9,129.1,123.6,88.6,59.1$; HRMS calcd. for $\mathrm{C}_{8} \mathrm{H}_{8} \mathrm{INO}_{3}$ 293.9627, found 293.9621. 


\section{References and notes}


1 Bird, C. W.; Cheeseman, W. H. (Eds) Comprehensive Heterocyclic Chemistry, Pergamon, Oxford, 1984, 4,1037-1038.

${ }^{2}$ Kumar, P. R.;, Raju, S.; Goud, P. S.;,Sailaja, M.; Sarma, M. R.; Reddy, O. G.; Kumar, M. P.; Reddy, V. V. R. M. K.; Suresh, T.; Hegde, P. Bioorg. Med. Chem. 2004, 12, 1221-1230

${ }^{3}$ Romanova, D.; Vachalkova, A.; Horvathova, K.; Krutošiková. A. Collect. Czech. Chem. Commun. 2001, 66, 1615-1623.

${ }^{4}$ Sleziak, R.; Krutošiková. A. Collect. Czech. Chem. Commun. 1999, 64, 321-329.

${ }^{5}$ Shafiee, A.; Zarghi, A.; Dehpour. A. R. Pharmaceutical Sciences. 1997, 3, 461-463

${ }^{6}$ Sasaki, S.; Shirahashi, Y.; Nishiyama, K.; Watanabe, H.; Hayase. F. Biosci. Biotechnol. Biochem. 2006, 70, 2529-2531

${ }^{7}$ Miyamoto, H.; Oyama, N.; Ohsaka, T.; Tanaka, S. Miyashi. T. J. Electrochem. Soc., 1991, 138, 2003-2007.

${ }^{8}$ Barker, A. J.; Kettle, J. G.; Faull, A. W.; WO Patent 9940914; Chem. Abstr.,1999, 131, 170342

9 (a) Ota, T.; Komoritani, S.; Yoshino, T.; Uoto, K.; Nakamoto, Y.; Naito, H.; Mochizuki, A.; Nagata, T.; Kanno, H.; Haginoya, N.; Yoshikawa, K.; Nagamochi, M.; and Kobayashi, Sh.; Japan Patent 2003183286; Chem. Abstr., 2003,139, 85363.

(b) Ohta, T.; Komoriya, S.; Yoshino, T.; Uoto, K.; Nakamoto, Y.; Naito, H.; Mochizuki, A.; Nagata, T.; Kanno, H.; Haginoya, N.; Yoshikawa, K.; Nagamochi, M.; Kobayashi, S.; Ono, M.; WO Patent 2003000657. Chem. Abstr., 2003, 138, 205076.

10 Nakamura, T., Hioki, T., Ohzeki, K., Hanaki, N., US Patent 2002058216, US; Chem. Abstr., 2002, 136, 393179.

${ }^{11}$ Rao, E. K.; Padmanabhan, S.; Lown, W. J. Actual. Chim. Ther. 1993, 20, 159

12 Hemetsberger, H.; Knittel, D. Monatsh. Chem. 1972, 103, 104.

${ }^{13}$ Eras, J.; Galvez, C.; Garcia, F. J. Heterocycl. Chem. 1984, 21, 215

${ }^{14}$ Knittel, D. Synthesis 1985, 186-8.

${ }^{15}$ Sleziak, R.; Balažiová, S .; Krutošiková. A. Collect. Czech. Chem. Commun. 1999, 64, $1135-46$ 
${ }^{16}$ Shafiee, A.; Hadizadeh, F.; Foroumadi, A.; Indian J. of Chemistry. 1997, 39B, 813

${ }^{17}$ Arad, O.; Morros, J.; Batllori, X.; Teixido, J.; Nonell, S.; Borrel. I. J. Org. Lett. 2006, 8, 847-50

18 Soth, S.; Farnier, M.; Paulmier. C. Can. J. Chem. 1978, 56, 1429

${ }^{19}$ Fischer, E.; Jourdan, F. Ber. 1883, 16, 2241

20 Shimkin, A. A.; Nikalin, D. M.; Shirinian, V. Z.; Krayushkin, M. M.; Vorontsova, L. G.; Metilitsa, A. V.; Minkin, V. I. Mol. Cryst. Liq. Cryst., 2005, 431, 307-313

${ }^{21}$ Binder, D.; Habison, G.; Noir, C. R. Synthesis. 1977, 487-489

22 Batcho, A. D.; Leimgruber, W. Org. Synth. 1985, 63, 214-220.

${ }^{23}$ Krayushkin, M. M.; Stoyanovich, F. M.; Shorunov, S. V. Mendeleev Commun. 2004, 14,29

24 Gronowitz, S.; Westerlund, C.; Hornfeldt. A. Acta Chemica Scandinavica. 1976, 30B, 391-396.

25 Sundberg, R. J.; Lin, L. S.; Blackburn, D. E. J. Heterocycl. Chem. 1969, 6, 441.

26 Sundberg, R. J. J. Org. Chem. 1965, 30, 3604.

27 (a) Cadagon, J. G.; Cameron-Wood, M.; Mackie, R. K.; Searle, R. G. J. Chem. Soc. 1965, 4831. (b) Cadagon, J. G.; Synthesis. 1969, 11.

28 (a) Srinivasan, K.; Srinivasan, K. G.; Balasubramanian, K. K.; Swaminathan, S. Synthesis, 1973, 5, 313. (b) Ontoria,J. M.; Hernando, J. M.; Malancona, S., Attenni, B.; Stansfield, I.; Conte, I.; Ercolani, C.; Habermann, J.; Ponzi, S.; Di Filippo,M.; Koch, U.; Rowley, M.; Narjes, F. Bioorg. Med. Chem. Lett. 2006, 16, 4026-4030.

${ }^{29}$ Kumar, G.; Rajagopalan, K.; Swaminathan, S. Indian Journal of Chemistry. 1979, 541.

30 Kumar, G.; Rajagopalan, K.; Swaminathan, S.; Balasubramanian, K. K. Indian Journal of Chemistry. 1981, $20 B, 271-274$.

${ }^{31}$ Reissert, A. Ber. 1897, 30, 1030.

32 Snyder, H. R.; Carpino, L. A.; Zack, Jr, J. F.; Mills, J. F. J. Am. Chem. Soc., 1957, 79, 2556-2559.

${ }^{33}$ Matteson, D. S.; Snyder, H. R. J. Org. Chem. 1957, 22, 1500. 
${ }^{34}$ Olsen, R. K.; Snyder, H. R. J. Am. Chem. Soc., 1965, 30, 184.

${ }^{35}$ Sommen, G.; Comel, A.; Kirsch. G. Tetrahedron, 2003, 59, 1557

36 Zavarin. I. B.; Smirnova, N. G.; Yarovenko, V. N.; Krayushkin, M. M. Russian Journal of Organic Chemistry, 2007, 43, 753-757.

${ }^{37}$ Sanz, R.; Escribano, J.; Pedrosa, M. R.; Aguado, R.; Arniaz, F. J. Adv. Synth. Catal. 2007, 349, 713-718.

38 Tolari, S.; Cenini, S, Crotti, C.; Gianella, E. J. Mol. Catal. 1994, 87, 203-14.

39 Stokes, B. J.; Dong, H.; Leslie, B. E.; Pumphrey, A. L.; Driver. T. G. J. Am. Chem. Soc. 2007, 129, 7500-7501

40 Wesbo, D.; Gronowitz, S. Tetrahedron 1996, 52,14975.

${ }^{41}$ Crotti, S.; Cenini, S.; Rindone, B.; Tollari, S.; Demartin, F. J. Chem. Soc., Chem. Comm. 1986, 784.

42 Söderberg, B. C. G. Current Organic Chemistry, 2000, 4, 727.

${ }^{43}$ Crotti, C.; Cenini, S.; Bassoli, A.; Rindone, B.; Demartin, F. J. Mol. Catal. 1991, 70, 175.

${ }^{44}$ Akazome, M.; Kondo, T.; Watanabe, Y. J. Org. Chem. 1994, 59, 3375.

45 Söderberg, B. C. G.; Shriver, J. A. J. Org. Chem. 1997, 62, 5838

46 (a) Hubbard, J. W.; Piegols, A. M.; Söderberg, B. C. G. Tetrahedron 2007, 63, 7077. (b) Söderberg, B. C. G.; Wallace, J. M.; Tamariz, J. Org. Lett. 2002, 4, 1339. (c) Scott, T. L.; Söderberg, B. C. G. Tetrahedron. 2003, 59, 6323. (d) Dantale, S. W.; Söderberg, B. C. G. Tetrahedron. 2003, 59, 5507. (e)Clawson, R. W.,Jr.; Deavers, R. E., III; Akhmedov, N. G.; Söderberg, B. C. G. Tetrahedron. 2006, 62, 10829. (f) Clawson, R. W.,Jr.; Söderberg, B. C. G. Tetrahedron Lett. 2007, 48, 6019. (g) Söderberg, B. C. G.; Banini, S. R.; Turner, M. R.; Minter, A. R.; Arrington, A. K. Synthesis. 2008, 6, 903.

47 "Synthesis of Azaindoles, Diazaindoles, and Advanced Carbazole Alkaloid Intermediates via Palladium-Catalyzed Reductive N-Heteroannulation." Master's thesis; Grissel Carrero-Martinez; 2008.

${ }^{48}$ Stille, J. K.; Angew. Chem., Int Ed. Engl. 1986, 25, 508.

49 Srinivasan, K.; Srinivasan, K. G.; Balasubramanian, K. K.; Swaminathan, S. Synthesis. 1973, 5, 313. 
50 Ballini, R.; Bartoli, G.; Boslpozza, B.; Marcantoni, E.; Dalpozzo, R. Tetrahedron. 1988, 44, 6435-6440.

${ }^{51}$ Rinkes, I. J. Recueil des Travaux Chimiques des Pays-Bas et de la Belgique. 1934, $53,643-51$.

52 Steinkopf, W.; Poulsson, I.; Herdey, O. Leibigs Ann., 1938, 128, 536

${ }^{53}$ Geetha, P.; Rajagopalan, K.; Swaminathan, S. Indian Journal of Chemistry., 1979, 17B, 163-164

${ }^{54}$ Saldabol, N. O.; Slavinska, V.; Popelis, J.; Mazeika, I. Latvijas Kïmijas Žurnāls. 2003, 73-77.

55 (a) Compound 115 was prepared from a procedure in Hara, T.; Kayama, Y.; Mori, T.; Itoh, K.; Fujimori, H.; Sunami, T. J. Med. Chem. 1978, 21, 263. (b) Kou, Y; Shih, Y. Chem. Pharm. Bull. 1991, 39, 181-183.(for spectral data) ${ }^{56}$ Hantzsch, A. Justus Liebigs Ann. Chem. 1889, 250, 265

${ }^{57}$ Hojo. M.; Ichi. T.; Masuda. R.; Kobiyashi, M.; Shibano. H. J. Org. Chem. 1988, 53, 2209-2213

58 (a) Ganapathi, K.; Venkatraman, A. Proceedings-Indian Academy of Sciences, Section A. 1945, 343-358. (b) Sych, E. D. Ukrains'kii Khemichnii Zhurnal. 1959. 25, 344-7.

59 Herrling, S; Mueckter, H. (Chemie Gruenenthal G.m.b.H.). 1963, DE 1159450 19631219

${ }^{60}$ Chan, E.; Putt, S. R.; Showalter. H. D. J. Org. Chem. 1982, 47, 3457-3464

${ }^{61}$ Chauvière, G.; Bouteille, B.; Enanga, B.; Albuquerque, C.; Croft, S. L.; Dumas, M.; Périé, J. J. Med. Chem. 2003, 46, 427-440

62 Rajanarender, E.; Mohan, G.; Ramesh, P.; Karunkar, D. Tetrahedron. Lett. 2006, 47, 4957

63 Perez, J. D.; Wunderlin. A. D. J. Org. Chem. 1987, 52, 3637.

64 Wakefield, B. J. Science of Synthesis. 2002, 11, 229.

65 Pavia, M. R. Organic Preparations and Procedures International. 1987, 19, 48-52. 
${ }^{66}$ (a) Firl, J.; Kresze, G. Chemische Berichte. 1966, 99, 3695-3706. (b) Firl, J.; Kresze, G. Tetrahedron. 1968, 24, 1043-1050.

67 tenHave, R.; Leusink, F. R.; Van Leusen, A. L. Synthesis 1996, 7, 871-876.

${ }^{68}$ Dockendorff, C.; Sahil, S.; Olsen, M.; Milhau, L.; Lautens, M.; J. Am. Chem. Soc. 2005, 127, 15028

69. Erdmann, O. L ."Untersuchungen über den Indigo": 1840.19, 321-362.

70 Laurent. A. Ann. chim. phys.1840, 3, 393-434.

71 Silva, J. F. M.; Garden, S. J.; Pinto. A. C. J. Braz. Chem. Soc.; 2001, 12, 273-324.

72 A. Baeyer, Ber., 1880, 13, 2259

${ }^{73}$ Claisen. L.; Shadwel. J. L., Ber. 1879, 12, 350.

${ }^{74}$ Sandmeyer, T. Helv. Chim. Acta. 1919, 2, 234.

75 Bran, M. F.; Gradillas, A.; Gomez, A.; Acero, N.; Llinares, F.; Mingarro, D. M.; Abradelo, C.; Stolle, F, R.; Yuste, M.; Miguel , J. C.; Gallo, A. A.; Espinosa, A. J. Med. Chem. 2004, 47, 2236.

${ }^{76}$ Newman, H.; Angier, R. B. J.Org.Chem, 1961, 26, 812.

${ }^{77}$ Kapadia, G. J.; Shukla, Y. N.; Chowdary, B. K.; Basan, S. P.; Fales, H. M.Tetrahedron 1980, 36, 2441.

78 Guyot, A.; Martinet, J. Compt. Rend. 1913, 156, 1625.

79 Gassman, P. G.; Cue Jr, B. W.; Luh, T. Y.; J. Org. Chem. 1977, 42,1344-1348.

${ }^{80}$ Reissert, A.; Ber, 1904, 37, 3710.

81 (a) Hewawasam, P.; Meanwell, N. Tetrahedron. Lett. 1994, 35, 7303. (b) Rivalle, C.; Bisogni, E. J. Heterocycl. Chem. 1997, 34, 441.

82 Smith, K.; El-Hiti, G. A.; Hawes, A. C. Synlett. 1999, 945.

${ }^{83}$ Yadav, J. S.; Subba Reddy, B. V.; Suresh Reddy, Ch.; Krishna, A. D. Synthesis. 2007, 5, 693-696.

${ }^{84}$ Parrick, J.; Yahya, A.; ljaz, A. S.; Yizun, J. J. Chem. Soc., Perkin Trans. 1. 1989. 2009.

${ }^{85}$ Kraynack, E. A.; Dalgard, J. E.; Gaeta, F. C. A. Tetrahedron Lett. 1998, 39, 7679 
86 Ozawa, F.; Yanagihara, H.; Yamamoto, A. J. Org. Chem. 1985, 51, 415

87 Hewlins, M. J. E.; Jacson, A. H.; Oliveira-Campos, A. M.; Shannon, P. V. R. J. Chem. Soc., Perkin Trans.1. 1981, 2906.

88 Cornforth, J. W. J. J. Chem. Soc., Perkin Trans.1. 1976, 2004.

89 Pfitzinger, W. J. Prakt. Chem. 1886, 33, 100.

${ }^{90}$ M. G. A. Shvekhgeimer. Chemistry of Heterocyclic Compounds, 2004, 40, 257

91 Shastin, A. V.; Korotchenko, V. N.; Nenjdenko, V. G.; Balenkova, E. S. Synthesis 2001, 14, 2081.

92 Sonogashira, K.; Tohda, Y.; Hagihara. N. Tetrahedron Lett. 1975, 16, 4467.

${ }^{93}$ Leonhard, K. W.; Meldal, M. Eur. J. Org. Chem. 2008, 5244.

${ }^{94}$ Nishikawa, T.; Shibuya, S.; Hosokawa, S.; Isobe, M. Synlett. 1994, 485

95 Corey, E. J.; Fuchs, P. L. Tetrahedron Lett. 1972. 36, 3769

${ }^{96}$ Baeyer, A. Chem. Ber. 1881, 41, 1741

${ }^{97}$ Rosen, G. M.; Tsai, P.; Bartg, E. D.; Dorey, G.; Casara, P.; Spedding, M.; Halpern, H. J. J. Org. Chem. 2000, 65, 4460.

${ }^{98}$ Krohnke, F.; Meyer-Delius, M. Chem. Ber. 1951, 10, 932-941

99 Splitter, J. S.; Calvin, M. J. Org. Chem. 1955, 20, 1086

100 Hooper, M.; Bond, C. C. Synthesis. 1974, 443

101 Chien, C. S.; Takanami, T.; Kawasaki, T.; Sakamoto, M. Chem. Pharm. Bull. 1985, 33, 1843-1848.

102 Slatt, J.; Bergman, J. Tetrahedron 2002, 58, 9187.

103 Hooper, M.; Robertson, J. Tetrahedron Lett. 1971, 12, 2139.

104 Noland, W. E.; Jones, D. A. J. Org. Chem. 1962, 27, 341.

105 Noland, W. E.; Modler, R. F. J. Am. Chem. Soc., 1964, 86, 2086-2087.

106 Asao, N.; Sato, K.; Yamamoto, Y. Tetrahedron Lett. 2003, 44, 5675-5677.

107 Bringmann, G.; Tasler, S.; Endress, H.; Peters, K.; Peters, E. Synthesis, 1998, 15011505. 
108 Progress in the Chemistry of Organic Natural Products. W. Herz, G. W. Kirby, H. Falk, D. P. Chakraborty, K. Krohn, C. Schäffer, P. Messner, S. Roy. page 131-132, Vol 85.Springer Wein New York.

109 The Alkaloids: Chemistry and Biology. Geoffrey A. Cordell. Vol 65, Elsevier Science \& Technology Books.

110 Arbiser, J, L.; Govindarajan, B.; Battle, T, E.; Lynch, R.; Franf, D. A.; Masuko, U.; Perry, B. N.; Stern, D, F.; Bowden, G. T.; Liu, A.; Klein, E.; Kolodziejski, P. J.; Eissa, N. T.; Hossain, C. F.; Nagle, D. G. Journal of Investigative Dermatology. 2006. 126, 1396 111 Kim, M. Y.; Lim, G. J.; Lim, J. I.; Kim, D. S.; Kim, I. Y.; Yang, J. S. Heterocycles 1997, 45, 2041.

112 Rodriguez, J. G.; Temprano, F.; Esteban-Calderon, C.; Martinez-Ripoll, M. J. Chem. Soc. Perkin Trans. 1 1989, 2117.

113 (a) Jash, S. S.; Biswas, G. K.; Bhattacharayya, S. K.; Bhattacharayya, P.; Chakraborty, A.; Chowdhury, B. K. Phytochemistry 1992, 31, 2503-2505. (b) Sowmithran, D.; Prassad, K. J. R. Heterocycles 1986, 24, 711-717.

114 "Palladium-Catalyzed Synthesis of Carbazole Derivatives and Formal Total Syntheses of Several Naturally Occurring Carbazole Alkaloids." Tricia. L. Scott . Ph.D Dissertation. 2002.

115 Johnson, C. R.; Adams, J. P.; Braun, M. P.; Senanayake, C. B. W. Tetrahedron Lett. 1992, 33, 919.

116 Saha, C.; Chowdary, B. K. Phytochemistry. 1998, 48, 363

117 Scott, T, L.; Xu, Y.; Gorugantula, S, P.; Carrero-Martinez, G.; Soderberg, B. C. Tetrahedron, 2006, 62, 10835.

118 Cuesta, X.; Gonzalez, A.; Bonjoch, J. Tetrahedron Asymmetry. 1999, 10, 3365

119 Chakravarty, A. K.; Sarkar, T.; Masuda, K.; Takey, T.; Doi, H.; Kotani, E.; Shiojima, K.; Indian Journal of Chemistry. 2001, 40B, 486.

120 Moskalev, N.; Makosza, M. Chem. Commun., 2001, 1248.

121 Wrobel, Z.; Makosza, M. Tetrahedron 1997, 53, 5501.

122 Bagley, M. C.; Dale, J. W.; Merritt, E. A.; Xiong, X. Chem. Rev., 2005, 105, 685.

123 Hughes, R. A.; Moody, C. J. Angew. Chem., Int. Ed., 2007, 46, 7930. 
124 Benazet, F.; Cartier, M.; Florent, J.; Godard, C.; Jung, G.; Lunel, J.; Mancy, D.; Pascal, C.; Renaut, J.; Tarridec, P.; Theilleux, J.; Tissier, R.; Dubost, M.; and Ninet, L. Experientia, 1980, 36, 414.

125 Kimber, M. C.; Moody. C. J. Chem. Commun., 2008, 591-593.

126 Soderberb, B. C. G.; Chisnell, A. C.; O’Neil, S. N.; Shriver, J. A. J. Org. Chem.1999, $64,9731-9734$.

127 Gilman, H.; Blatt, A. H. Organic Syntheses, Collective Volumes I and II, Second Edition; John Wiley \& Sons, Inc.: New York, 1967; 56-7 \& 127.

128 Elbaum, D.; Porco, J. A.; Stout, T. J.; Clardy, J.; Schreiber, S. L. J. Am. Chem. Soc. 1995, 117, 211.

129 Lu, X.; Zhu, G.; Ma, S. Chinese Journal of Chemistry. 1993. 11, 267.

130 Wan, P.; Muralidharan, S.; McAuley, I.; Babbage, C. A. Canadian Journal of Chemistry 1987, 65, 1775-83.

131 Heck, R. F.; Nolley, Jr. J. P. J. Org. Chem. 1972, 14, 2330.

132 Soderberg, B. C. G.; Hubbard, J. W.; Rector, R. S.; O’Neil. S. N. Tetrahedron. 2005, 61, 3637-3649.

133 Hassner, A.; Friedman, O.; Dehaen, W. Leibigs Annalein Recueil, 1997, 587.

${ }^{134}$ As recorded by Chet Howerton.

135 No further analysis could be performed on the sample due to observed unstability.

136 Commercially available.

137 Marshall, R. W.; Hengde, C. A. J. Org. Chem. 1990.1, 197.

138 Sadler, P. W. J. Org. Chem. 1956, 21, 169-170.

139 Pavlidis, V. H.; Perry, P. J.; Synth. Commun. 1994, 24, 533-548.

140 NMR data in complete agreement: Radhy, H, A.; Fadhil, G. F.; Perjessy, A.; Kolehmainen, E; Fabien, W. M. F.; Samalokova, M.; Laihia, H. K.; Sustekova, Z. Heterocyclic Commun. 2001, 7, 387-392. (b) Onishi, T; Tetrahedron 2004, 42, 9503. 141 Kailia, N.; Janz, K.; Huang, A.; Moretto, A.; DeBernado, S.; Bedard, P. W.; Tam, S.; Clerin, V.; Keith, Jr., J. C.; Tsao, D. H.; Sushkova, N.; Shaw, G. D.; Camphausen, R. T.; Schaub, R. G.; Wang, Q. J. Med. Chem. 2007, 50, 40-64. 
142 Gassman, P. G.; Halweg, K. M. J. Org. Chem. 1979, 44, 628.

143 Sandler, P. W.; J. Org. Chem. 1956, 21, 169-170.

144 Gershuns, A. L.; Pavlyuk, A. A. Ukr. Khim. Zh. 1964, 30, 1086-1089.

145 Lackey, K.; Sternbach, D. D. Synthesis 1993, 993-997.

146 Gulland, J. M.; Robinson, R., Scott, J.; Thornley, S. J. Chem. Soc. 1929, 2924-2941.

147 Knolker, H.; Bauermeister, M.; Pannek, J.; Wolpert, M. Synthesis 1995, 397-407

148 Toshio, H.; Kiyoshi. T. Bulletin of the Chemical Society of Japan. 1936. 11. 218-20. 